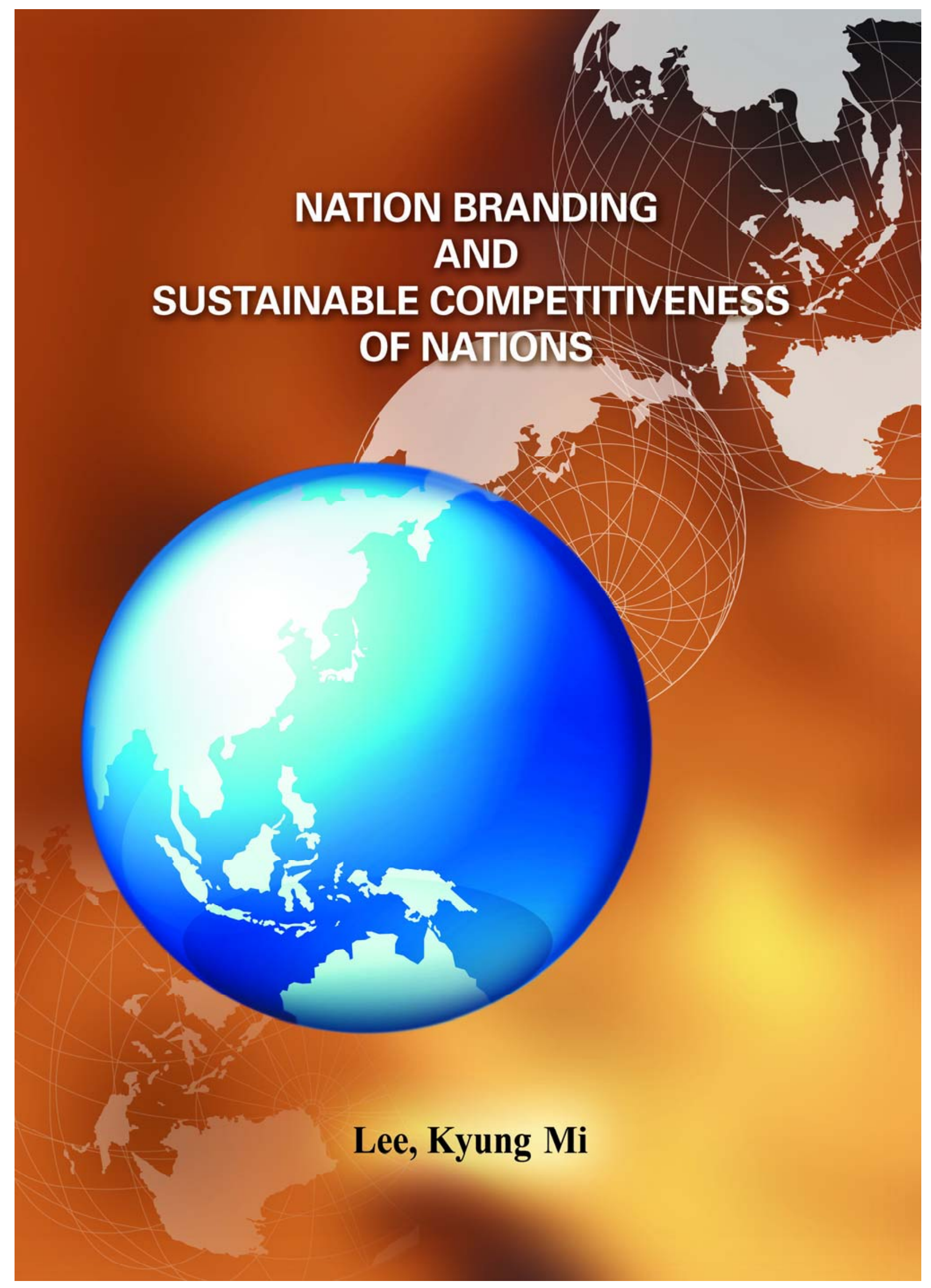




\section{NATION BRANDING \\ AND \\ SUSTAINABLE COMPETITIVENESS OF NATIONS}

\section{DISSERTATION}

to obtain

the degree of doctor at the University of Twente,

on the authority of the rector magnificus,

Prof. Dr. H. Brinksma,

on account of the decision of the graduation committee,

to be publicly defended

on Friday $06^{\text {th }}$ of March 2009 at 16.45

by

Lee, Kyung Mi

born on $20^{\text {th }}$ of December 1968

in Buyeo, South Korea 
This dissertation has been approved by

Promotor: $\quad$ Prof. Dr. Ir. E. J. de Bruijn

Assistant promotor:Dr. Ir. S. J. de Boer 
Promotion Committee:

Chairman: Prof. Dr. P. J. J. M. van Loon University of Twente

Secretary: Prof. Dr. P. J. J. M. van Loon University of Twente

Promotor: Prof. Dr. Ir. E. J. de Bruijn University of Twente

Members: Dr. Ir. S. J. de Boer University of Twente

Prof. Dr. P. B. Boorsma University of Twente

Prof. Dr. D. S. Cho Seoul National University

Prof. Dr. J. C. van Dalen University of Wageningen

Prof. Dr. Ir. O. A. M. Fisscher University of Twente

Prof. Dr. A. J. Groen University of Twente 

Dedicated to my family, colleagues and friends 
Lee, Kyung Mi

Nation Branding and Sustainable Competitiveness of Nations

PhD Thesis, University of Twente, the Netherlands - With ref.

ISBN: 978-90-365-2803-0

DOI: $10.3990 . / 1.9789036528030$

Copyright @ 2009 by Kyung Mi Lee, Enschede, the Netherlands

All rights reserved. No part of this publication may be reproduced, stored in a retrieval system, or transmitted in any form by any means, electronic, mechanical photocopying, recording or otherwise, without the written consent of the author. Request for permission should be directed to the author at:

E-mail:1ennalee77@gmail.com/k.m.lee@utwente.nl 


\section{PREFACE AND ACKNOWLEDGEMENTS}

Nation branding is about creating a nation's values and benefits for its people, and sustaining its competitiveness. In this research, it is assessed that nations can sustain their competitiveness through strategic nation branding. A nation's competitiveness has been defined as the nation's ability to create its competitive advantage and sustainable development for its people. Nations have been measured in terms of their competitiveness yearly by a world index. However, it is questionable whether such an index is sufficient to provide nations with ways of improving and sustaining their competitiveness. I will argue it is time for nations to increase their abilities to create a nation brand which is the core value of their competitiveness and then to manage it through nation branding. This thesis aims to help nations which are eager to find ways of nation branding that improve their competitiveness and make their people's better lives.

Nations have followed a nation branding approach for several decades. They are currently deploying it in various ways. Since the $11^{\text {th }}$ September 2001 , the USA has increasingly experienced negative feelings towards America. Incorporating the key members of US corporations, cultural entertainment and academia into the branding process, the US government takes a proactive role to expand its diplomatic efforts in shaping "Brand America." Recently, the New York Philharmonic played American music in the heart of communist North Korea in an historic concert, and this is a way of branding the USA through symbolic actions such as "musical diplomacy." The EU sets forth Europe's identity and image, attempting its own brand-building efforts. Nations in the EU have been re-branding their identities and images through cultural attractions, creative knowledge and competences. Asian countries have created authentic experiences for tourists and business people, and are co-branding with companies or service brands to improve their national images.

Some nations have achieved good results over dramatically short time periods. Others may have spent lots of money without any brand effects. Until the end of 1990s, nation branding was vague in its terminology, and was simply part of promoting a country's image. However, the United States - renowned as the highest nation brand value deliberately focuses on improving Brand America. The ideas of nation branding and sustainable competitiveness provide nations with opportunities why and how they adopt nation branding for their competitiveness.

During the writing of this thesis, many of the ideas came from previous researchers, media and books, which gave me enormous insights into why nation branding is necessary to nations and how it contributes to knowledge. In addition, I have gained precious knowledge about how to conceptualize nation branding research. In particular, I would like to express my deep respect for Prof. Dong Sung Cho and Simon Anholt. They put the fundamental stone of nation branding study into academic thought and into practice. In particular, I would like to convey my pleasure to Keith Dinnie. When I opened his book - 
'Nation Branding' - I was so pleased to have it and was challenged to contribute to nation branding study with a good quality thesis. Their passion for and love of nation branding have inspired my strong motivation to continue this research. My special thanks go to John Coleman of IDA Ireland, Sang Wook Kim of KOTRA (Korea Trade-Investment Promotion Agency), Do Hoon Kim of KIET (Korea Institute for Industrial Economics and Trade) and Man Gi Jung of MOCIE (Ministry of Commerce, Industry and Energy of Korea). They gave a lot of their time for interviews and data sources, and provided me with great information regarding the Korean and Irish brands. Also, I have benefited from many experts who are working in the governments of Korea and Ireland. Specially, I would like to thank Byung Gook Lee of the Office for Government Policy Coordination of Korea. When I started my research into nation branding in 2003, he shared his great enthusiasm for building a Korean Image and since then he has given me invaluable support by encouraging me to be a specialist in nation branding.

I have received great comments and advice from Prof. De Bruijn and Prof. A. Groen. They gave generously of their time to review and comment on my thesis, and I have had the great fortune to rethink and upgrade this thesis based on their critical observations. Dr. Sirp de Boer over the years has taught me how to write a thesis, and it is to him that this thesis also is dedicated. I wish him a speedy recovery and good health.

I spent 2006-2007 as a visiting scholar in London University, where I got motivated with intellectual stimulus to extend my research scope. I am sincerely grateful to Soo Hee Lee and my friends (TaeYoung, Tariq, JiSeon and HeeSun). Also, I would like to thank Prof. Jae Beom Kim of SungKyunKwan University and Prof. Ken Nah of IDAS. I have also benefited from many friends and colleagues in NIKOS. In particular, I thank Kodo, Asif, Alafi, Mustafa and Sara who have given me great support during the years. Mariska and Wouter helped me to translate the summary into Dutch, which I very much appreciate. Our UT members and Korean Professors have been my proud supporters over the years. Goldking, my friends and Six-Maya are always excellent patrons.

As always, my deepest debt is owed to my husband, Yong Gook Choi, and my family. I would like to dedicate all the glory of this thesis to my grandmother and my parents. When I have been exhausted, they came to my dream with good luck and encouraged me to restart. I am very happy to make my aunts and uncles, sisters (EunHee, SooJin and HaeJin), brothers (DongHoon, Daniel, JungKyu, DongHo, SeungHoon, SeungGoo and SungHoon) and their children proud of me. 


\section{SUMMARY}

In this era of increasing globalization, nations attempt to attract foreign investors, tourists and creative workers into their countries, to increase market share and to command premium prices in global markets. To improve national development and competitive advantage both internally and externally, nations aim to obtain nation brand equity which is based on both national identities and images of symbolic 'soft power'. To sustain these values, nations rely on the continuing role of nation branding. Research shows a wide range of definitions of what nation branding is and how it works in creating, improving and sustaining a nation's values and competitiveness.

Nation branding encompasses activities from country naming through to all the collected activities of the country. Researchers of nation branding have argued that nation branding is a managed process of building the brand identity, image and reputation. Nations put efforts into nation branding with the help of various branding techniques. However, there are limitations in the theoretical and practical approaches to nation branding. Firstly, the brand management of a nation is often considered merely as a simplistic notion of creating a visual identity or communicating a promotional campaign. Secondly, despite the nature of nation branding involving complex multidimensional facets and unpredictable tasks, research has mainly been limited to considering how a nation brand should be managed and nation branding is a managed process conducted in a holistic and systematic way. Thirdly, even though the existing literature on nation branding has emphasized a nation's brand and branding with respect to national development, competitive advantage and sustainability contexts, there has been limited attention paid to explaining the relevance of nation branding with respect to the sustainability and competitiveness of nations. Particularly in regard to the notions of sustainability and brand alignment, this research highlights the importance of explaining how a nation brand is effectively managed and how nation branding aligns the nation brand with country management so as to achieve sustainable competitiveness of nations. This research aims to assess the role of nation branding and create a strategic management tool on nation branding for the sustainable competitiveness of nations.

To define the role of nation branding and develop a strategic management tool on nation branding with respect to the sustainable competitiveness of nations, we focus on performance in nation branding - the extent to which the variables in nation branding contribute to the achievement of the sustainable competitiveness of a nation as the outcome of nation branding. Particularly in respect of performance in nation branding, we highlight the need to take a brand management approach based on the application of a systematic model. This includes explaining how a nation brand's elements may be integrated and managed, and how nation branding achieves the sustainable competitiveness of a nation in a systematic way. Therefore, this research formulates the following research questions: (1) how does nation branding contribute to the sustainable competitiveness of nations? 
Moreover (2) how can we design a comprehensive framework for nation branding that facilitates effectively the sustainable competitiveness of a nation?

We adopt a deductive approach to constructing a theoretical model that explains performance in nation branding. A five-step strategy of systematic research contains: reviewing the literature; building the research model; developing the research protocol; collecting and analyzing data; and extending the research model.

To develop an effective nation-branding model in terms of the sustainable competitiveness of nations, Chapter 2 reviews the literature concerning the concepts of nation branding and sustainable competitiveness. An overview of the nation-branding context with the domains of country-of-origin, place development and public diplomacy is provided. The research focuses on four aspects of key nation-branding concept that relate to causal variables of performance in nation branding: (1) aligning a nation brand with a national strategy; (2) building a nation brand strategy; (3) building a nation brand identity and image; and (4) managing nation brand behaviour. The concept of sustainable competitiveness as performance outcome in nation branding is examined in terms of competitiveness and nation brand equity. Existing models of nation branding are evaluated, and it is highlighted whether such models incorporate the key variables of nation branding in terms of achieving sustainable competitiveness.

Chapter 3 presents a research model that can explain performance in nation branding. The chapter includes the criteria for developing a nation-branding model, the typology of models in general, and the compatibility of models for nation branding. Finally, we propose the Nation-Branding Mechanism Model (NB-MM) as a 'mechanism-based process model' explaining a dynamic sequence of brand behaviours that contextually take place within a nation-brand system and that influence the sustainable competitiveness of a nation. The NB-MM sums up an input-process-output framework, and the process consists of the sequential phases of creating a nation-brand vision (C-NBV), setting a nation-brand goal (S-NBG), developing a nation-brand strategy (D-NBS) and operating a nation-brand strategy (O-NBS).

To study the subject in its current setting, this research selects two cases, namely the Republic of Korea and the Republic of Ireland, based on the criteria as follows:

- Each has distinguished its own nation-specific development path

- Each has developed its own FDI or export branding system

- Each has a similar category level of auto-identification and country image, implying the level of nation brand status

- Each has undergone a period of evolutionary change (i.e. epoch) inspired by influential national leaders

- Each has multiple events of nation branding based on longitudinal scope 
Based on the performance criteria in the 'Nation-Branding Mechanism Model (NBMM)', we analyze the ESTI (Export, Science, Technology and Industry)-brand system of Korea and the FIEK (FDI, Industry, Enterprise and Knowledge)-brand system of Ireland. Exploring the nation-specific branding mechanisms within the nation-brand systems, our research identifies the cross-case patterns in branding. Data collected about Korea's and Ireland's branding show similarities and differences in the nation-branding process. In particular, testing the model on the Korea and Ireland cases, this research highlights the important empirical findings in nation branding as follows:

- Nation branding is a process that must align with country management and influences the sustainable competitiveness of a nation.

- Nation branding is the process that needs a systematic approach to building a nation brand.

- Nation branding is the mechanism-based process that structures a set of activities carried out by branding actors.

- Nation branding is an ongoing and iterative process to develop and maintain the nation-brand system and to influence the sustainable competitiveness of a nation.

Investigating contextual variables of the nation branding process through empirical testing, the research affirms the 'Nation-Branding Mechanism Model (NB-MM)' as an effective model for explaining performance in nation branding. Through developing the NB-MM, this research contributes to the building of a body of knowledge of defining the role of nation branding as strategic management tool for achieving the sustainable competitiveness of a nation. Firstly, in concrete terms, the study provides a strategic management process model that is suitable for aligning the nation brand with country management and explaining the management role of nation branding that influences the sustainable competitiveness of the nation. Secondly, we highlight the adoption of a mechanism-based process model to explain how nations develop a nation-specific brand system and therefore provide a mechanism-based nation branding theory. Thirdly, this research contributes to providing the reality-based brand management approach to building and managing the nation's identity and image. Finally, our study contributes to designing a strategic nation-brand management model that creates systematically the nation-brand system and sustains effectively the nation's competitiveness. 


\section{SAMENVATTING}

In het tijdperk van toenemende globalisering trachten landen buitenlandse investeerders, toeristen en creatieve medewerkers aan te trekken om hun marktaandeel te vergroten en premiumprijzen te verkrijgen in geglobaliseerde markten. Om nationale ontwikkeling en concurrentievoordeel te verbeteren, zowel intern als extern, beogen landen voordeel te behalen met hun 'nation-branding' gebaseerd op zowel hun nationale identiteit als hun beelden van symbolische 'soft power'. Om deze waarden te verstevigen vertrouwen landen op de voortdurende functie van nation-branding. Uit onderzoek komt een breed scala aan definities naar voren met betrekking tot wat nation-branding is en hoe dit werkt in het creëren, verbeteren en in stand houden van de waarden en het concurrentievermogen van landen.

'Nation-branding' omvat activiteiten vanaf de naamgeving van een land tot en met alle verzamelde activiteiten van het land. Onderzoekers wijzen er op dat nation-branding een gestuurd proces is van het opbouwen van merkidentiteit, imago en reputatie. Landen werken aan nation-branding met behulp van uiteenlopende branding-technieken. Echter, er bestaan beperkingen in de theoretische en praktische benaderingen van nation-branding. In de eerste plaats wordt het merkbeheer van een land vaak slechts beschouwd als een eenvoudige gedachte van het creëren van een visuele identiteit of het communiceren van een promotiecampagne. In de tweede plaats heeft onderzoek, ondanks dat de aard van nation-branding complexe multi-dimensionele facetten en onvoorspelbare taken betreft, zich vooral beperkt tot het beschrijven van hoe een nation-brand moet worden bestuurd en dat nation-branding een bestuurd proces is dat uitgevoerd wordt op een holistische en systematische manier. In de derde plaats, ondanks dat de nation-branding literatuur het belang benadrukt heeft van een nation-brand en branding met betrekking tot nationale ontwikkeling, concurrentievoordeel en duurzaamheidcontexten, is er beperkte aandacht besteed aan het uitleggen van de relevantie van nation-branding met betrekking tot de duurzaamheid en het concurrentievermogen van landen. In het bijzonder ten opzichte van noties van duurzaamheid en merkgerichtheid wordt in dit onderzoek de nadruk gelegd op het belang van het verklaren hoe een nation-brand effectief wordt bestuurd en hoe nationbranding het nation-brand op één lijn brengt met het landsbestuur teneinde duurzaam concurrentievermogen van landen te bereiken. Dit onderzoek beoogt de rol van nationbranding te beoordelen en een strategisch nation-branding managementgereedschap te creëren ten behoeve van het duurzaam concurrentievermogen van landen.

Om de rol van nation-branding te definiëren en om een strategisch managementgereedschap te ontwikkelen ten behoeve van het duurzame concurrentievermogen van landen, staat centraal hoe landen presteren met betrekking tot nation-branding. Met presteren wordt bedoeld de mate waarin de variabelen in nation-branding bijdragen aan het bereiken van het duurzame concurrentievoordeel van een land als resultaat van nationbranding. In het bijzonder met het oog op de prestaties in nation-branding wordt de nadruk 
gelegd op de noodzaak om brand-management te benaderen als de toepassing van een systematisch model. Daarbij wordt uitgelegd hoe de elementen van een nation-brand geïntegreerd en bestuurd kunnen worden, en hoe nation-branding op systematische wijze leidt tot duurzaam concurrentievermogen van een land. In dit onderzoek worden daarom de volgende onderzoeksvragen geformuleerd: (1) Op welke wijze draagt nation-branding bij tot het duurzame concurrentievermogen van landen? Daarnaast, (2) op welke wijze kan een veelomvattend raamwerk voor nation-branding worden ontworpen, dat effectief het duurzame concurrentievermogen van landen bevordert.

We gebruiken een deductieve benadering voor de opbouw van een theoretisch model dat de prestaties van nation-branding verklaart. Een strategie voor het systematisch onderzoeken omvat de volgende vijf fasen: het bespreken van de literatuur, het opbouwen van het onderzoeksmodel, het ontwikkelen van het onderzoeksprotocol, het verzamelen en analyseren van data en het uitbreiden van het onderzoeksmodel.

Om een effectief model te ontwikkelen voor het duurzame concurrentievermogen van landen, bespreekt hoofdstuk 2 de literatuur over de concepten nation-branding en duurzaam concurrentievermogen. Er wordt een overzicht gegeven van de nation-branding context met behulp van de domeinen 'land van herkomst', 'plaatsontwikkeling' en 'publieke diplomatie'. Het onderzoek richt zich op vier aspecten van het hoofdconcept nation-branding, die betrekking hebben op causale variabelen van de nation-branding prestaties: (1) het in overeenstemming brengen van een nation-brand met een nationale strategie; (2) het bouwen van een nation-brand strategie; (3) het bouwen van de nation-brand identiteit en imago; en (4) het managen van nation-brand gedrag. Het concept duurzaam concurrentievermogen als prestatieresultaat van nation-branding wordt bestudeerd in termen van concurrentie-vermogen en nation-brand vermogen. Bestaande modellen van nation-branding worden geëvalueerd en er wordt nagegaan of dergelijke modellen de hoofdvariabelen van nation-branding omvatten ten behoeve van het bereiken van duurzaam concurrentie-vermogen.

Hoofdstuk 3 presenteert een onderzoeksmodel dat de prestaties van nation-branding kan verklaren. Het hoofdstuk bevat de criteria voor het ontwikkelen van een nationbranding model, de typologie van modellen in het algemeen, en de verenigbaarheid van modellen van nation-branding. Tenslotte stellen we het 'Nation-Branding Mechanism Model' (NB-MM) voor als een procesmodel gebaseerd op mechanismen, dat de dynamische opeenvolging van merkgedragingen verklaart die contextueel plaatsvinden in een nation-brand systeem en die het duurzame concurrentievermogen van een land beïnvloeden. Het NB-MM omvat een input-proces-output raamwerk; het proces bestaat uit de opeenvolgende fasen van het creëren van een nation-brand visie (C-NBV), het bepalen van een nation-brand doel (S-NBG), het ontwikkelen van een nation-brand strategie (DNBS) en het uitvoeren van de nation-brand strategie (O-NBS). 
Om het onderwerp te onderzoeken in de huidige omgeving selecteert het onderzoek twee cases, namelijk de Republiek Korea en de Republiek Ierland, op basis van de volgende criteria:

- Elk heeft een eigen landenspecifieke ontwikkelingspad onderkend.

- Elk heeft haar eigen branding systeem ontwikkeld, directe buitenlandse investeringen of export.

- Elk heeft een vergelijkbaar categorieniveau van zelfidentificatie en landenimago, wat het niveau weergeeft van de status van het nation-brand.

- Elk heeft een periode van evolutionaire verandering ondergaan (d.w.z. tijdperk), geïnspireerd door invloedrijke nationale leiders.

- Elk heeft meerdere gebeurtenissen van nation-branding beschouwd over een langdurige periode.

Gebaseerd op de prestatiecriteria in het 'Nation-Branding Mechanism Model' (NBMM) analyseren we het ESTI-merksysteem (Export, Science and Technology, and Industrial development) van Korea en het FIEK-merksysteem (FDI, Industry, Enterprise and Knowledge development) van Ierland. Door het onderzoeken van de landenspecifieke branding-mechanismen binnen de nation-brand systemen identificeert onze studie de crosscase-patronen met betrekking tot branding. De verzamelde data over de Koreaanse en Ierse branding laten overeenkomsten en verschillen zien in het nation-branding proces. In het bijzonder, door het testen van het model op de Koreaanse en Ierse cases, benadrukt dit onderzoek de volgende belangrijke bevindingen in nation-branding:

- Nation-branding is een proces dat overeen moet komen met het landenmanagement en het beïnvloedt het duurzaam concurrentievermogen van een land.

- Nation-branding is een proces dat een systematische benadering vereist om een nation-brand op te bouwen.

- Nation-branding is een proces dat op mechanismen is gebaseerd en dat een set activiteiten structureert die uitgevoerd worden door branding-actoren.

- Nation-branding is een voortdurend en iteratief proces om het nation-brand systeem te ontwikkelen en te onderhouden en om het duurzaam concurrentievermogen van een land te beïnvloeden.

Door het onderzoeken van contextuele variabelen van het nation-branding proces door middel van empirische testen bevestigt de studie het 'Nation-Branding Mechanism Model' als een effectief model om prestaties van nation-branding te verklaren. Door de ontwikkeling van het NB-MM draagt dit onderzoek bij aan het opbouwen van een kennisgebied over het definiëren van de rol van nation-branding als een strategisch management-tool om duurzaam concurrentievermogen van een land te bereiken. Ten eerste biedt deze studie in concreto een strategisch management procesmodel dat geschikt is voor het in overeenstemming brengen van het nation-brand met het landenmanagement en voor het verklaren van de rol van nation-branding management, dat van invloed is op het duurzame concurrentievermogen van het land. Ten tweede benadrukken we het gebruik van een op mechanismen gebaseerd procesmodel om te verklaren hoe landen een 
landenspecifiek brand-systeem ontwikkelen en bieden daarmee een op mechanismen gebaseerde branding-theorie. Ten derde biedt dit onderzoek een bijdrage aan de op de realiteit gebaseerde brand-management benadering ten behoeve van de opbouw en het management van de identiteit en het imago van een nation. Tenslotte draagt deze studie bij aan het ontwerp van een strategisch nation-brand managementmodel, dat systematisch het nation-brand systeem creëert en effectief het concurrentievermogen van het land ondersteunt. 


\section{TABLE OF CONTENTS}

Preface and Acknowledgements ........................................................

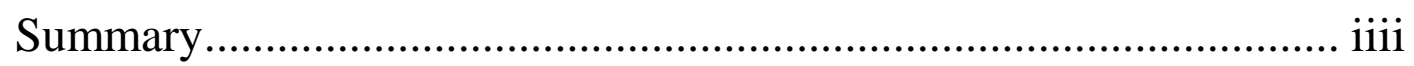

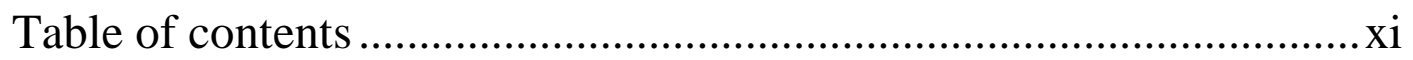

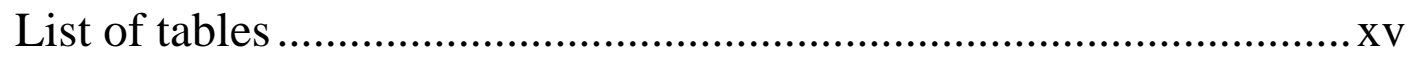

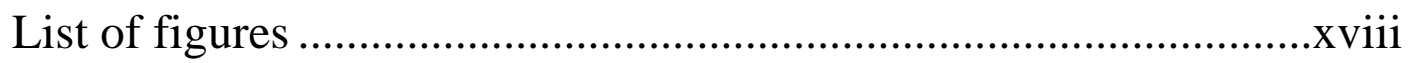

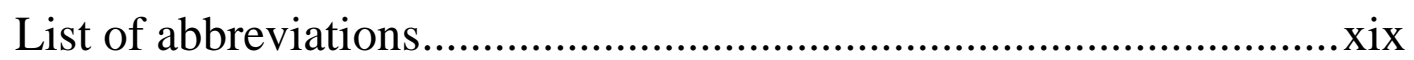

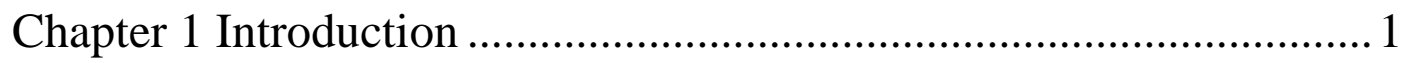

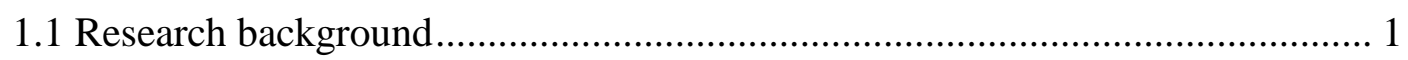

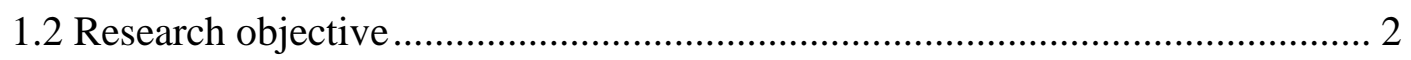

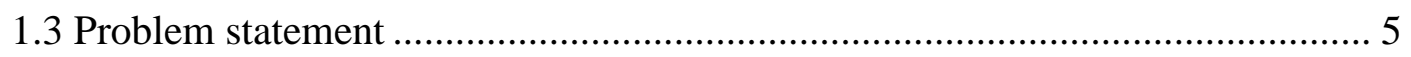

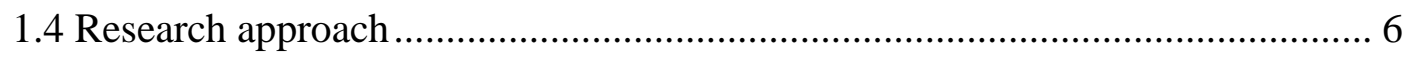

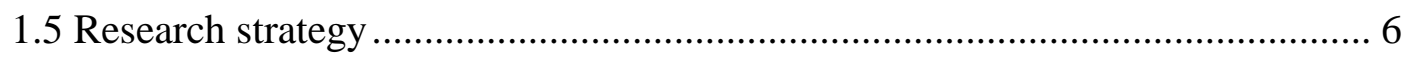

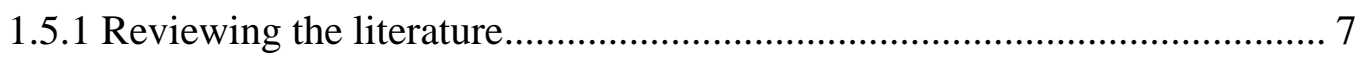

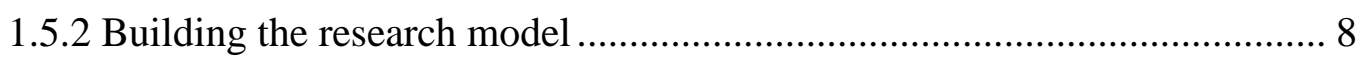

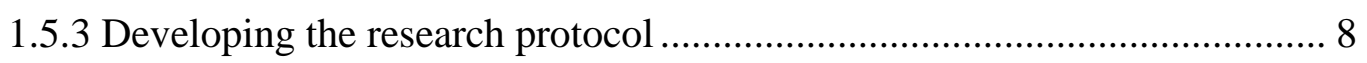

1.5.4 Collecting and analyzing data............................................................. 9

1.5.5 Extending the research model............................................................ 9

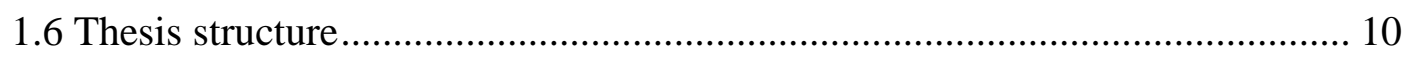

Chapter 2 Nation Branding and Sustainable Competitiveness............. 11

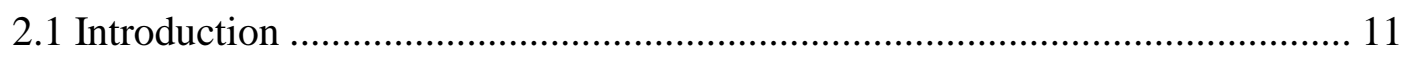

2.2 Concepts and evolution of nation branding ................................................... 11

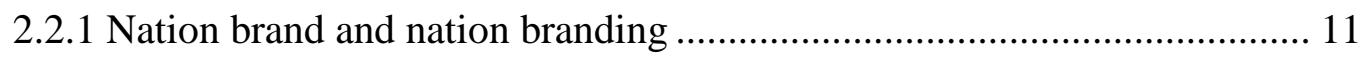

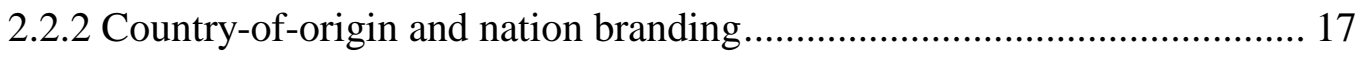

2.2.3 Place development and nation branding ................................................ 22

2.2.4 Public diplomacy and nation branding ................................................... 30

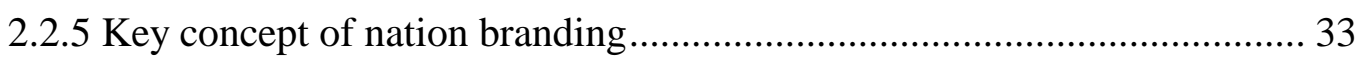

2.3 Nation branding and sustainable competitiveness ............................................ 44

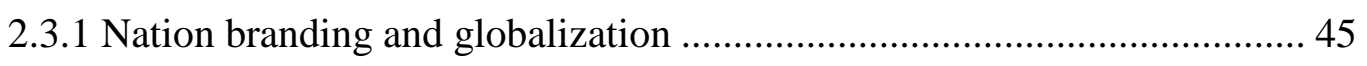

2.3.2 Key concept of sustainable competitiveness …………………………..... 46

2.4 Models of nation branding...................................................................... 56

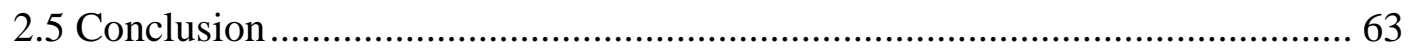


Chapter 3 A Nation-Branding Mechanism Model................................65

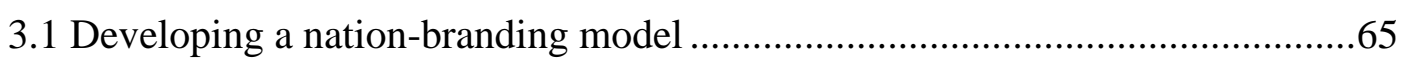

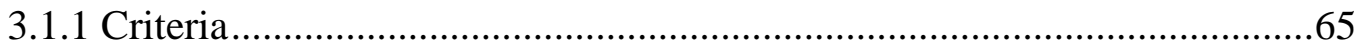

3.1.2 Typology of a model: factor or process model ........................................67

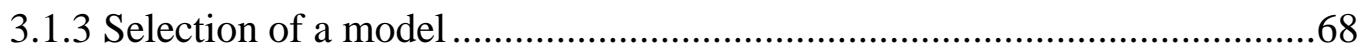

3.1.4 Adaptation: a mechanism-based process approach ...................................73

3.2 A Nation-Branding Mechanism Model (NB-MM) …………………...............75

3.2.1 Phase I. Creating a nation-brand vision (C-NBV) .....................................75

3.2.2 Phase II. Setting a nation-brand goal (S-NBG) ..........................................78

3.2.3 Phase III. Developing a nation-brand strategy (D-NBS) .............................79

3.2.4 Phase IV. Operating a nation-brand strategy (O-NBS) …………................82

3.2.5 Sustenance of competitiveness of a nation.................................................. 85

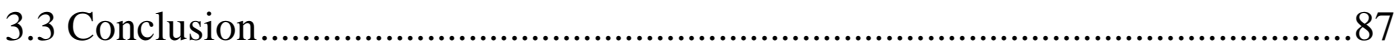

Chapter 4 Developing the Research Protocol .......................................89

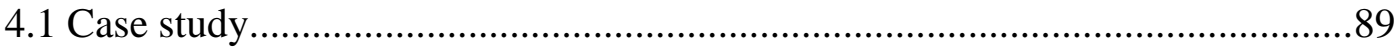

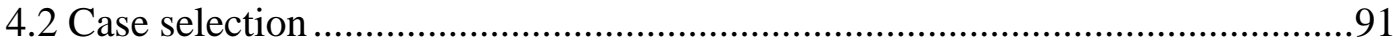

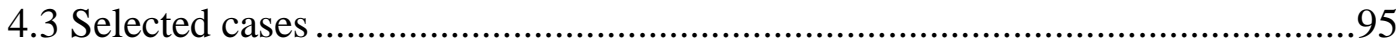

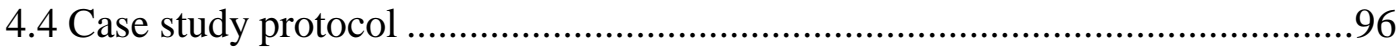

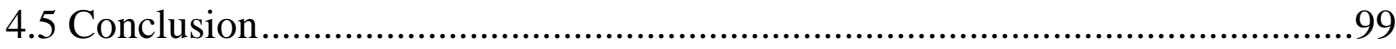

Chapter 5 Branding of Korea ............................................................... 101

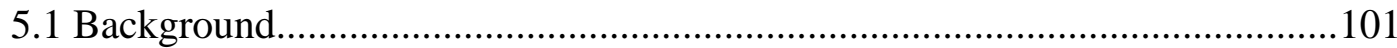

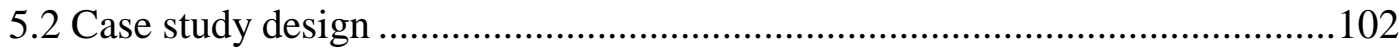

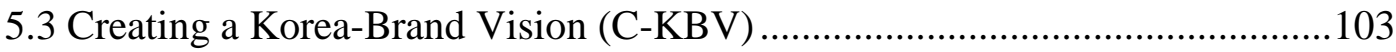

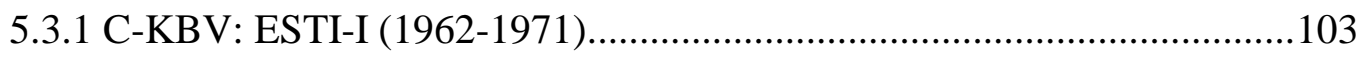

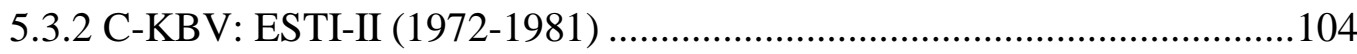

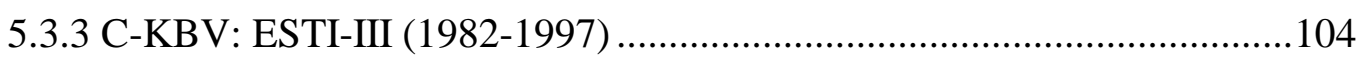

5.4 Setting a Korea-Brand Goal (S-KBG) ........................................................... 105

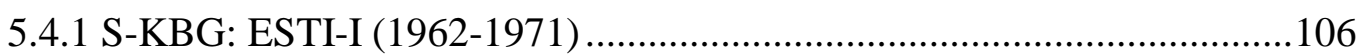

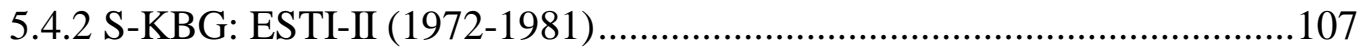

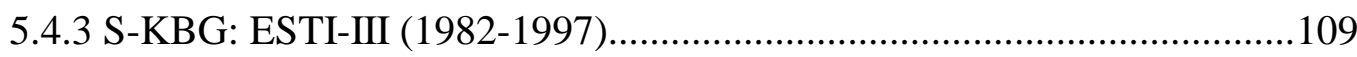

5.5 Developing a Korea-Brand Strategy (D-KBS) ………….............................111

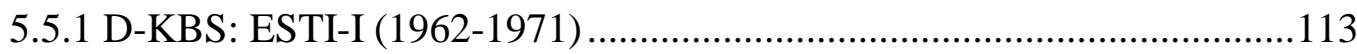

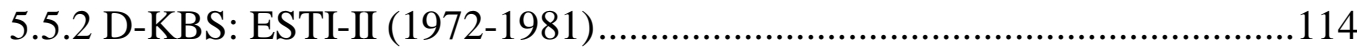

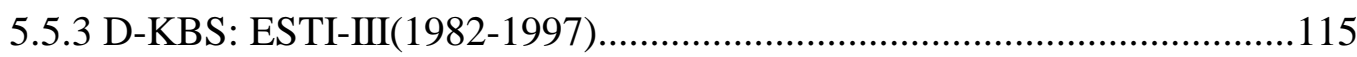

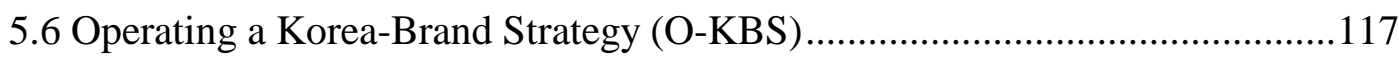

5.6.1 O-KBS: ESTI-I (1962-1971) ………………………............................117 


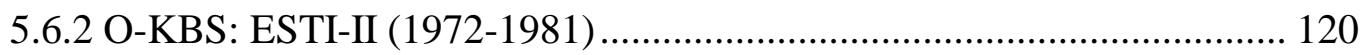

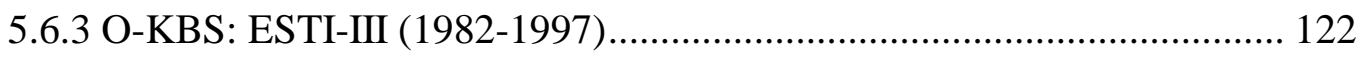

5.7 Sustenance of competitiveness of Korea ................................................. 126

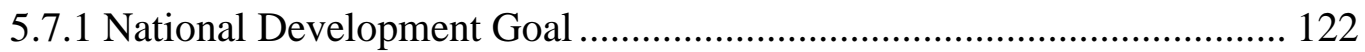

5.7.2 Project-based Goal Achievement ...................................................... 122

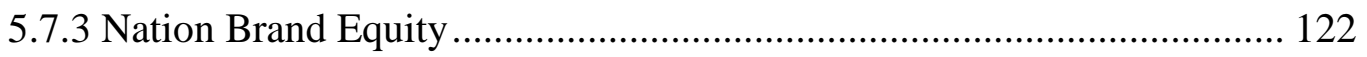

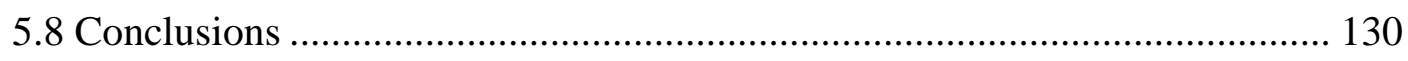

Chapter 6 Branding of Ireland ......................................................... 133

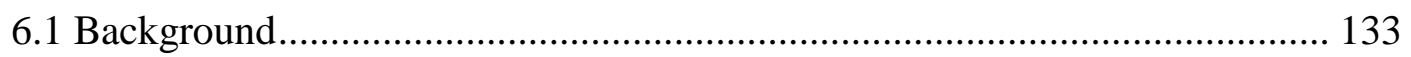

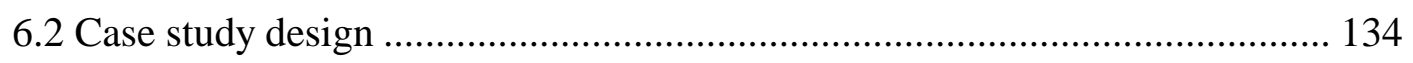

6.3 Creating an Ireland-Brand Vision (C-IBV) .............................................. 135

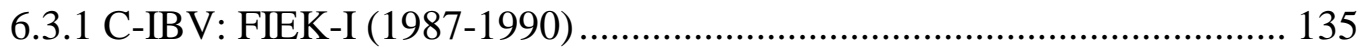

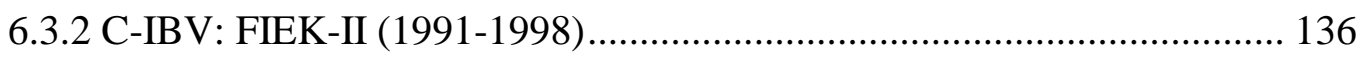

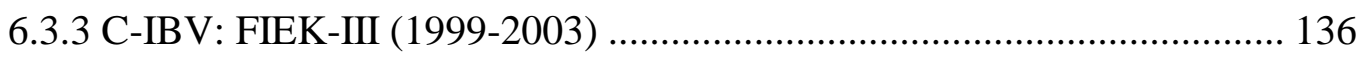

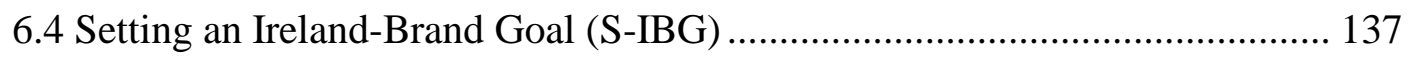

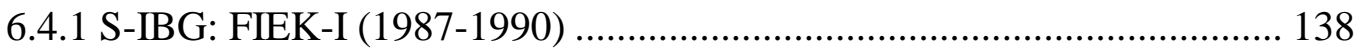

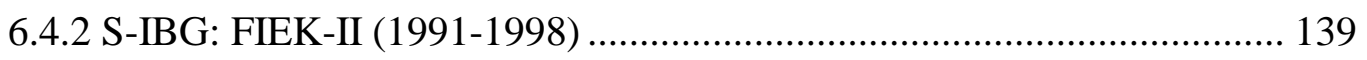

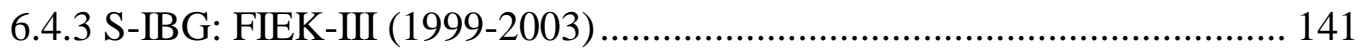

6.5 Developing an Ireland-brand Strategy (D-IBS) ........................................... 142

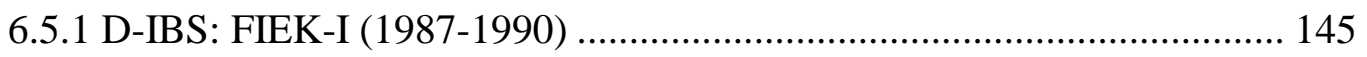

6.5.2 D-IBS: FIEK-II (1991-1998) .............................................................. 146

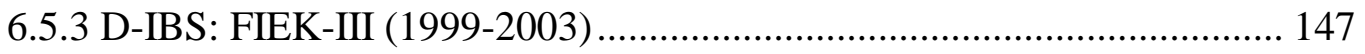

6.6 Operating an Ireland-Brand Strategy (O-IBS) ............................................ 148

6.6.1 O-IBS: FIEK-I (1987-1990) ............................................................. 149

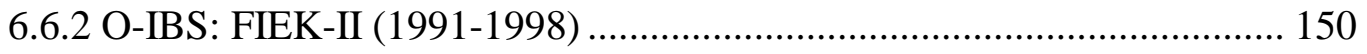

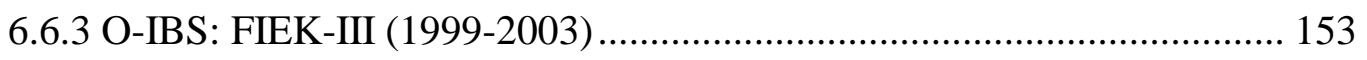

6.7 Sustenance of competitiveness of Ireland................................................... 156

6.7.1 National Development Goal ............................................................ 122

6.7.2 Project-based Goal Achievement ....................................................... 122

6.7.3 Nation Brand Equity ...................................................................... 122

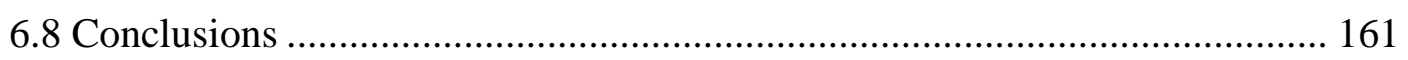

Chapter 7 Analysing Performance in Korea and Ireland Branding... 165

7.1 Performance in nation branding ............................................................... 165

7.1.1 Creating a nation-brand vision (C-NBV) ............................................... 166

7.1.2 Setting a nation-brand goal (S-NBG) ................................................ 169

7.1.3 Developing a nation-brand strategy (D-NBS) ...................................... 174

7.1.4 Operating a nation-brand strategy (O-NBS) ....................................... 181 
7.1.5 Sustenance of competitiveness of nations 186

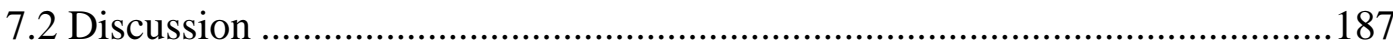

Chapter 8 Conclusions and Recommendations .................................191

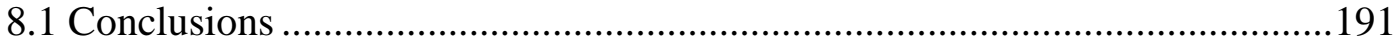

8.1.1 A process model for nation branding .....................................................191

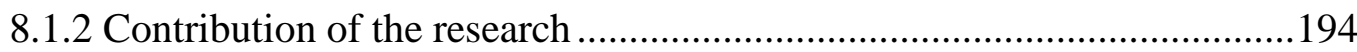

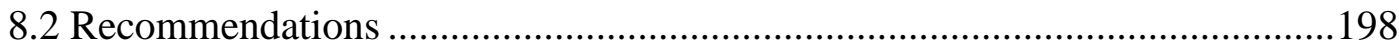

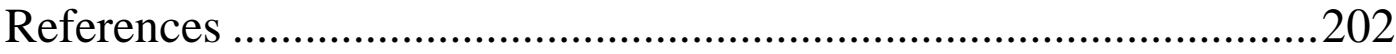

Appendix: Data Collection Protocol.............................................223

A1 Scheme for data collection procedure ….................................................223

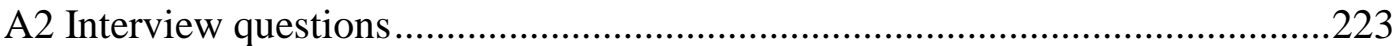

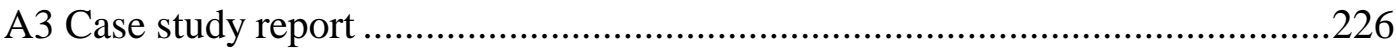

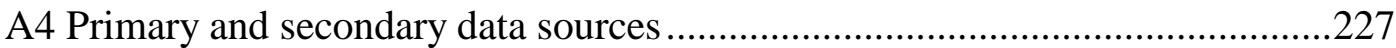




\section{LIST OF TABLES}

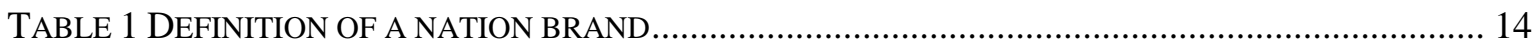

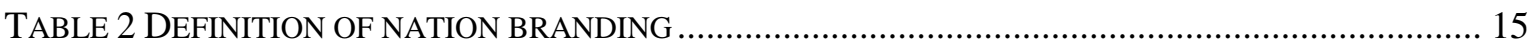

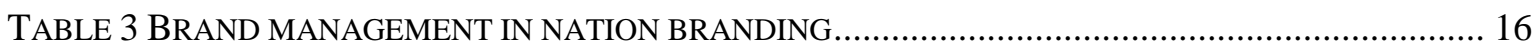

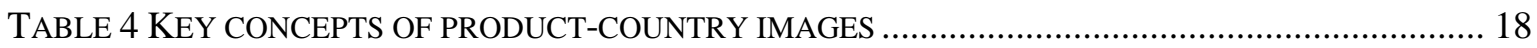

TABLE 5 COGNITIVE, AFFECTIVE AND NORMATIVE MECHANISMS FOR COUNTRY-OF-ORIGIN

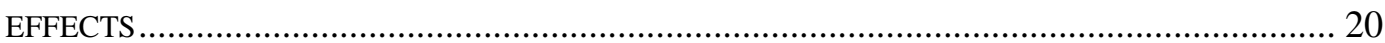

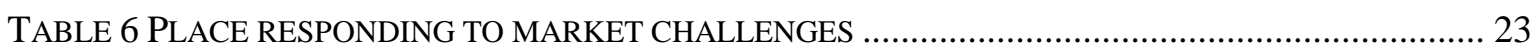

TABLE 7 BRAND CONCEPTUALISATIONS FROM THE PLACE MARKETING PERSPECTIVE ................... 27

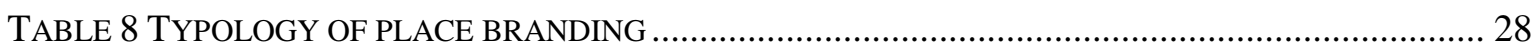

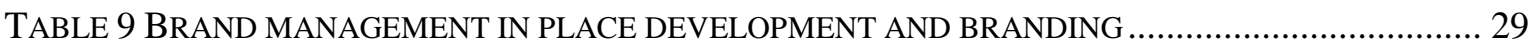

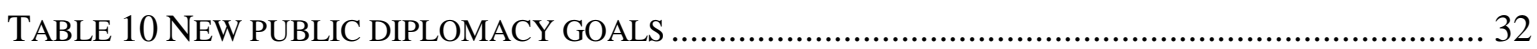

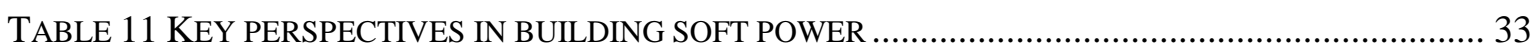

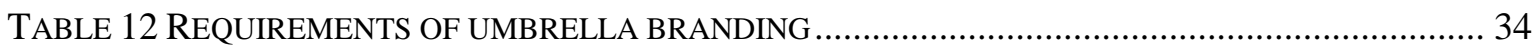

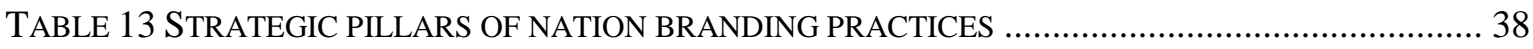

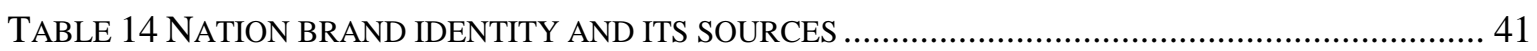

TABLE 15 THE CATEGORIES OF STAKEHOLDERS FOR NATION BRANDING....................................... 44

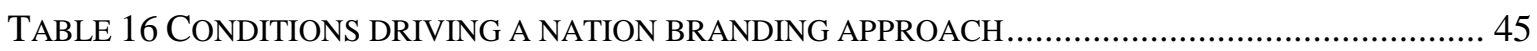

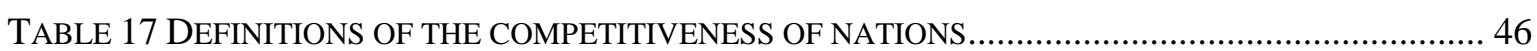

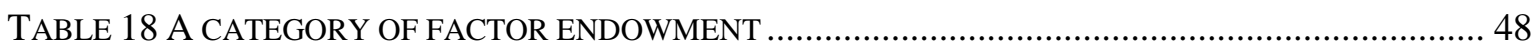

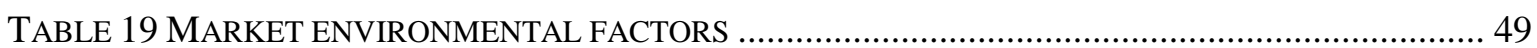

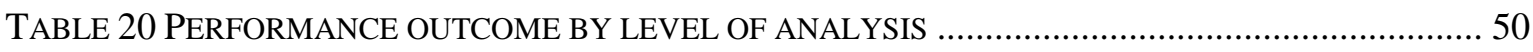

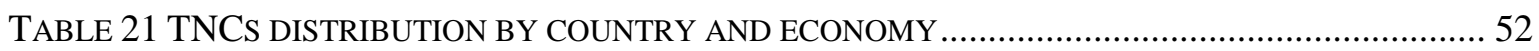

TABLE 22 SUSTAINABLE HUMAN DEVELOPMENT INDICATORS ........................................................ 53

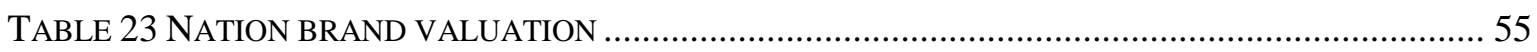

TABLE 24 MODELS ALIGNING A NATION BRAND WITH A NATIONAL STRATEGY …............................ 56

TABLE 25 MODELS BUILDING A NATION BRAND STRATEGY …….................................................. 58

TABLE 26 MODELS BUILDING THE NATION BRAND IDENTITY AND IMAGE ........................................ 59

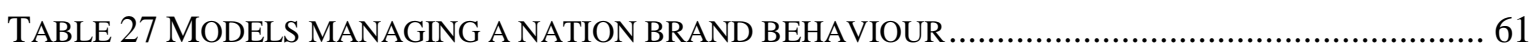

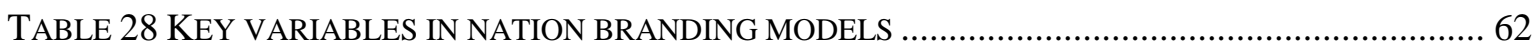

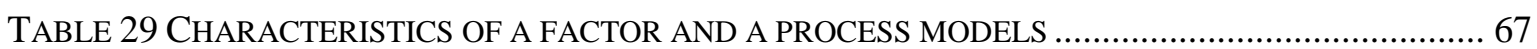

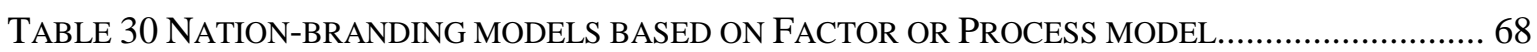

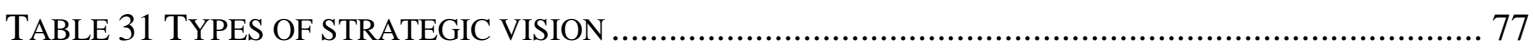

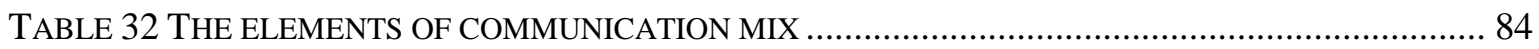

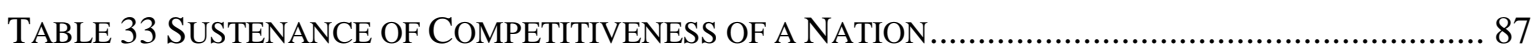

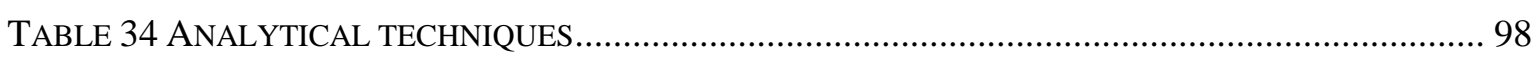

TABLE 35 EXPECTED NATIONAL ECONOMIC OUTCOMES THROUGH FIVE-YEAR PLANS ................. 106

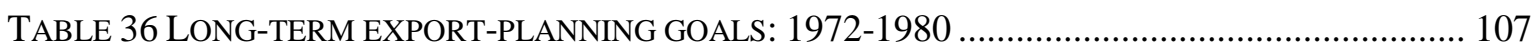

TABLE 37 THE PATTERN OF EXPORT DEPENDENCE ON THE USA AND JAPAN IN ASIA NICS .......... 107

TABLE 38 EXPORT MARKET SHARES OF MAIN INDUSTRIAL PRODUCTS............................................ 108

TABLE 39 THE MANUFACTURING INDUSTRY STRUCTURE: 1970-1976 _.......................................... 109 
TABLE 40 EXPORT GOALS OF INDUSTRIAL SECTORS AND PRODUCTS

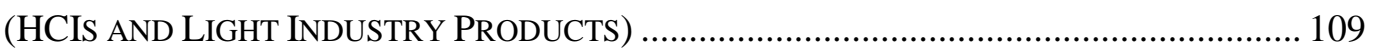

TABLE 41 CONTRIBUTIONS OF MAIN SOURCES IN NATIONAL ECONOMIC GROWTH (\%) .................. 110

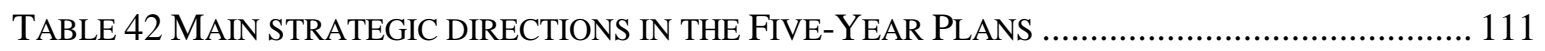

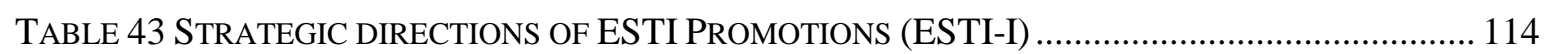

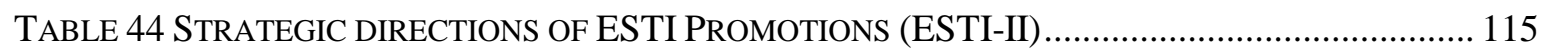

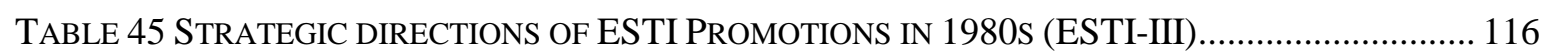

TABLE 46 STRATEGIC DIRECTIONS OF ESTI PROMOTIONS IN 1990S (ESTI-III).............................. 117

TABLE 47 ESTI PROMOTIONS DURING THE FIRST AND SECOND FYPS: ESTI-P (I) ........................ 119

TABLE 48 ESTI PROMOTIONS DURING THE THIRD AND FOURTH FYPS: ESTI-P (II) ....................... 121

TABLE 49 ESTI PROMOTIONS DURING THE FIFTH THROUGH NEW ECONOMY FYPS:

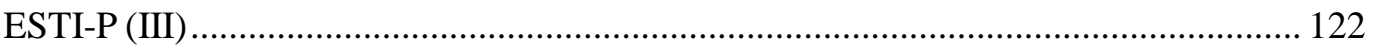

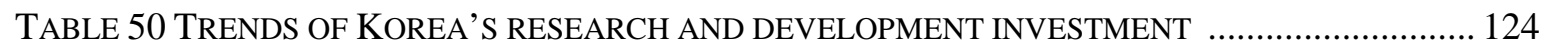

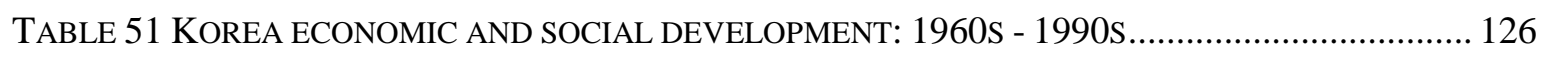

TABLE 52 KOREA'S EXPORTS AND ITS CONTRIBUTION TO ECONOMIC GROWTH ................................ 127

TABLE 53 EXPORT PRODUCT STRUCTURE BY MAJOR INDUSTRY GROUPS IN KOREA (\%)................ 128

TABLE 54 PRIMARY EXPORT MARKETS AND THIRTEEN PRODUCTS' MARKET SHARES

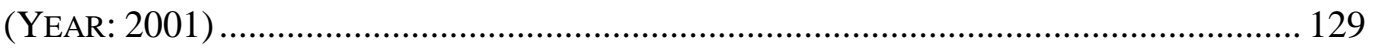

TABLE 55 EXPECTED NATIONAL GOALS THROUGH NATIONAL DEVELOPMENT PROGRAMMES ....... 138

TABLE 56 FEATURES AND SOURCE OF OVERSEAS INVESTMENT: 1985-1986 _............................... 138

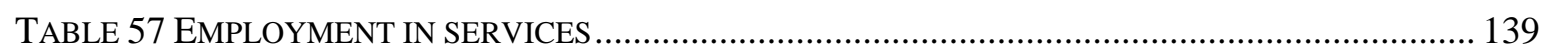

TABLE 58 MAIN STRATEGIC DiRECTIONS IN PROGRAMME FOR NATIONAL RECOVERY (PNR)...... 143

TABLE 59 MAIN STRATEGIC DIRECTIONS IN PROGRAMME FOR ECONOMIC AND SOCIAL

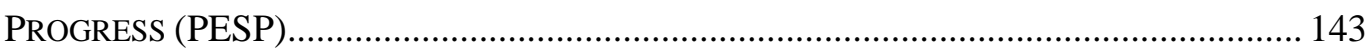

TABLE 60 MAIN STRATEGIC DIRECTIONS IN PROGRAMME FOR COMPETITIVENESS AND WORK

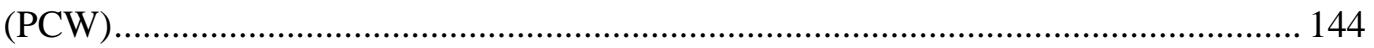

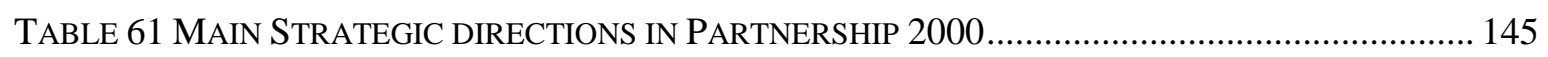

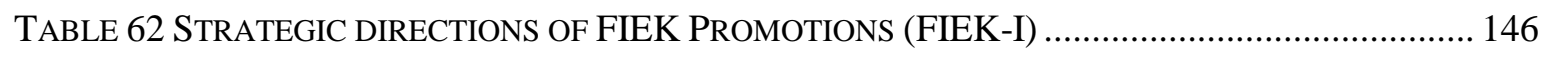

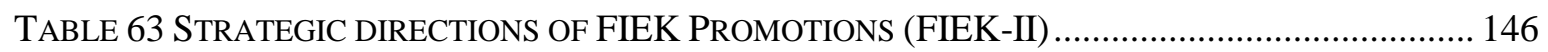

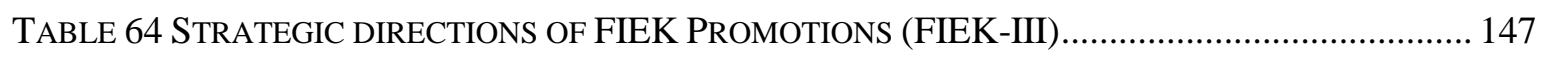

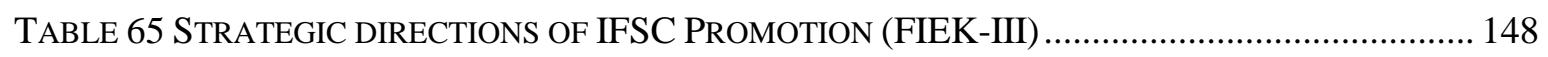

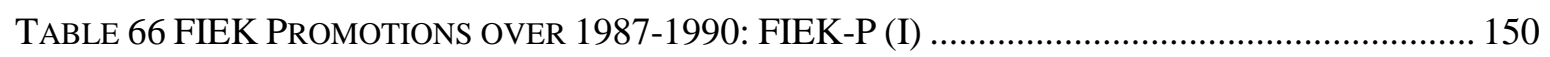

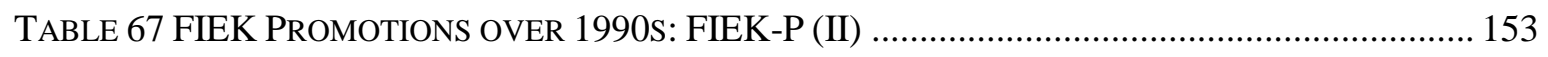

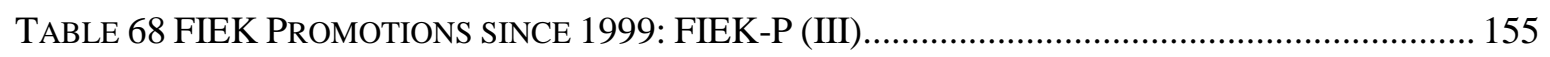

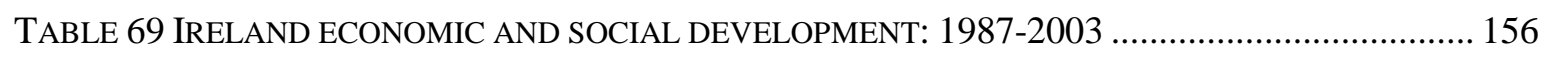

TABLE 70 NET ASSETS OF EUROPEAN INVESTMENT FUNDS INDUSTRY (DEC. 2003)....................... 158

TABLE 71 AGENCY-SUPPORTED FIRMS IN MANUFACTURING AND INTERNATIONALLY-TRADED

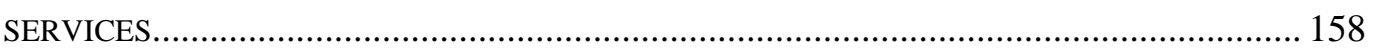

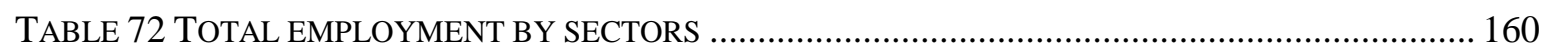

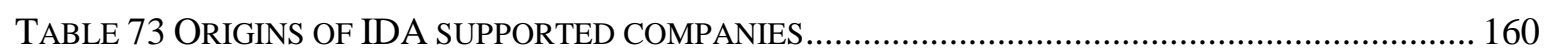

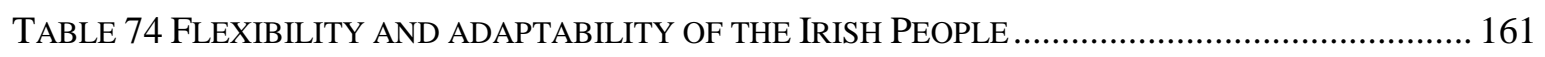

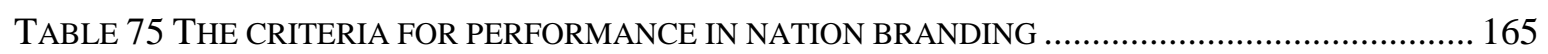

TABLE 76 CREATING A NATION-BRAND VISION: KOREA-BRAND VISIONS AND IRELAND-BRAND

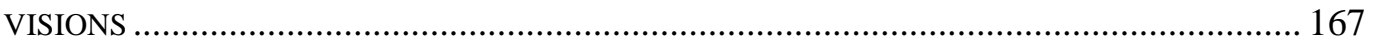


TABLE 77 THE CHARACTERISTICS OF STRATEGIC NATION-BRAND VISIONS IN KOREA AND

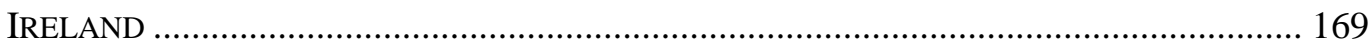

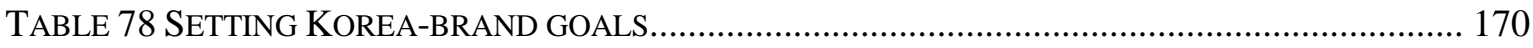

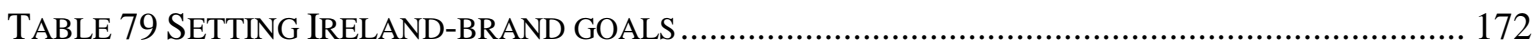

TABLE 80 BRANDING ACTORS IN KOREA-BRAND GOALS (KBG) AND

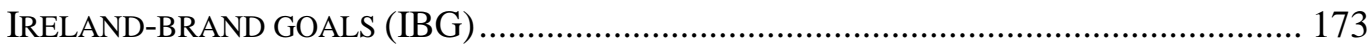

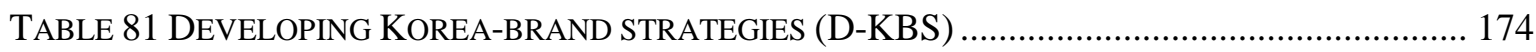

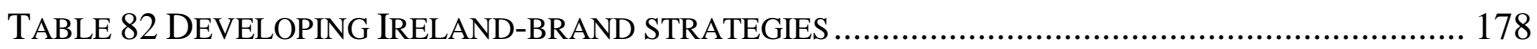

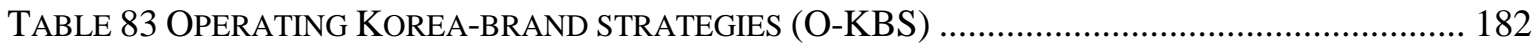

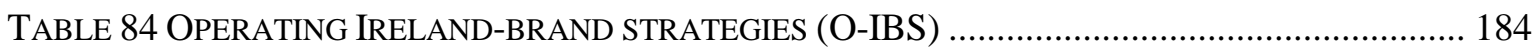

TABLE 85 SUSTENANCE OF COMPETITIVENESS OF KOREA AND IRELAND ....................................... 186 


\section{LIST OF FIGURES}

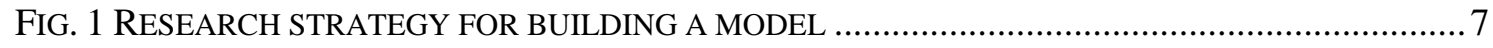

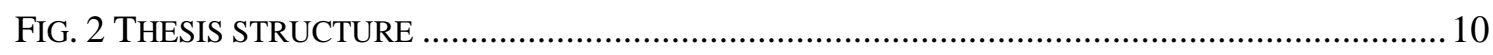

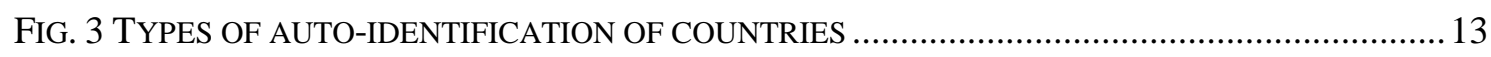

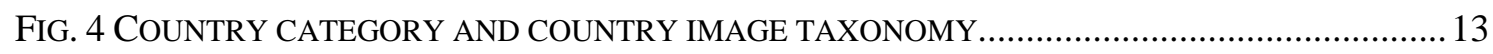

FIG. 5 AN INFORMATION PROCESSING MODEL OF RELATIVE PRODUCT IMAGE............................... 19

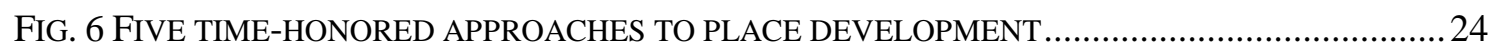

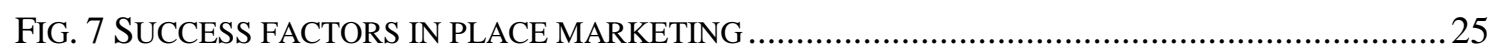

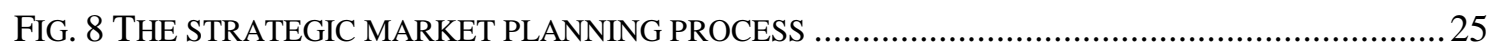

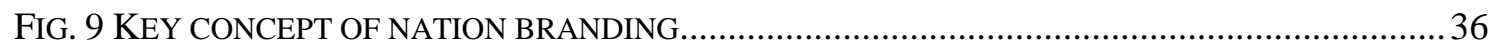

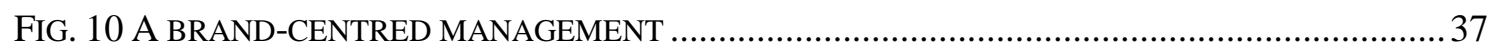

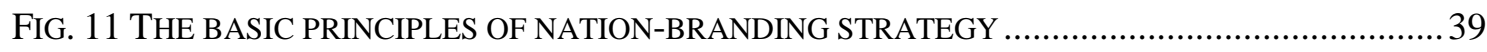

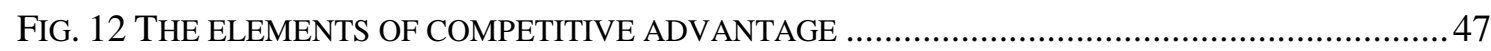

FIG. 13 INDEX OF CURRENT VALUE OF EXPORTS AND FOREIGN-DIRECT INVESTMENT

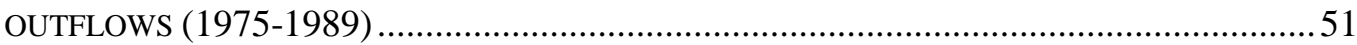

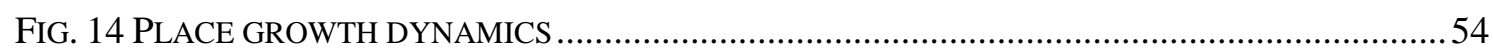

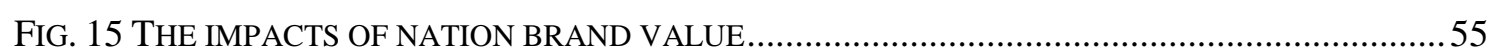

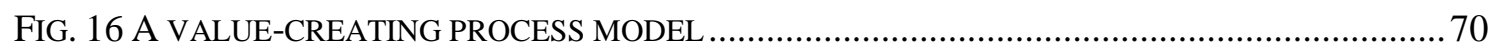

Fig. 17 A NATION-BRANDing MeChanism Model (RESEARCH ModEL) ................................... 75

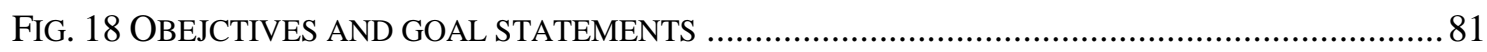

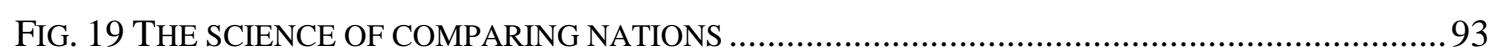

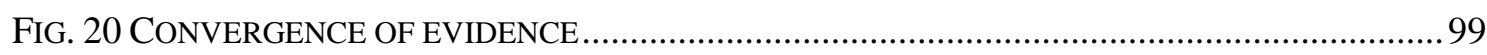

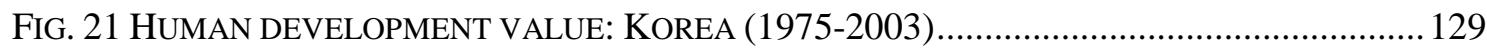

FIG. 22 COMPARISON OF KOREAN PRODUCTS PURCHASED BY GLOBAL MARKETS .................... 132

FIG. 23 INTERNATIONALLY TRADED AND INTERNATIONAL FINANCIAL SERVICES

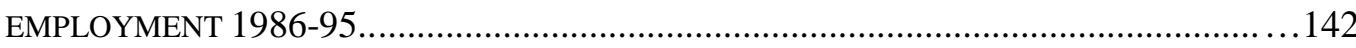

FIG. 24 KEY TRENDS IN INFORMATION, TELECOMMUNICATIONS AND COMPUTING

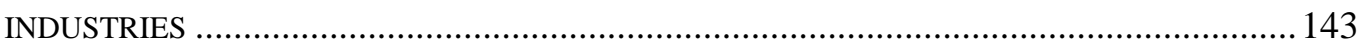

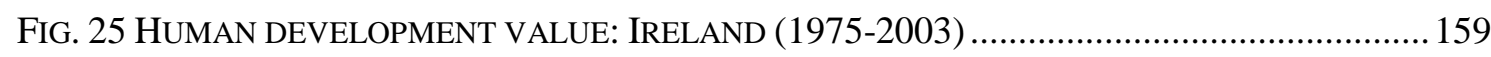

FIG. 26 FOREIGN DIRECT INVESTMENT INWARD STOCK (\% OF GDP), 2000-2004 ..................... 161

FIG. 27 DEVELOPING KOREA-BRAND STRATEGY AND IRELAND-BRAND STRATEGY .................. 182

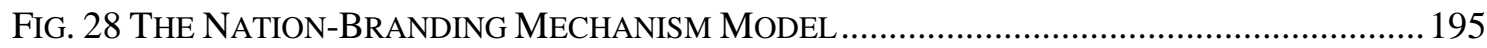




\section{LIST OF ABBREVIATIONS}

CHDDA: Customs House Docks Development Authority

C-NBV: Creating a Nation-Brand Vision

COO: Country-of-Origin

DC: Designed-in Country

DCF: Discounted Case Flow

DDDA: Dublin Docklands Development Authority

D-NBS: Developing a Nation-Brand Strategy

EMU: European Monetary Unit

EPB: The Economic Planning Board

EPS: Export Promotion Strategy

ESTI: Export, Science and Technology, and Industrial development

ESTI-P: ESTI-brand Promotions

FDI: Foreign Direct Investment

FIEK: FDI, Industry, Enterprise and Knowledge development

FYPs: Five-Year Plans

GAO: Government Accountability Office

GATT: General Agreement on Tariffs and Trade

HCIs: Heavy and Chemical Industries

HDI: Human Development Index

IBG: Ireland's Brand Goal

IBS: Ireland's Brand Strategy

IBV: Ireland's Brand Vision

ICTs: Information and Communication Technology industries

IDA: Industrial Development Agency

IFSC: International Financial Services Centre

IMD: International Institute for Management Development

IP: Industrial Development Promotion

IPS: Industrial Promotion Strategy

KBG: Korea's Brand Goal

KBS: Korea's Brand Strategy

KBV: Korea's Brand Vision

KDI: Korea Development Institute

KOTRA: Korea Trade-Investment Promotion Agency

LDCs: Less Developed Countries

MC: Made-in Country

MDCs: More Developed Countries

NBE: Nation Brand Equity 
NBG: Nation Brand Goal

NB-MM: Nation-Branding Mechanism Model

NBS: Nation Brand Strategy

NBV: Nation Brand Vision

NDPs: National Development Programmes

NESC: National Economic and Social Council

NICs: Newly Industrializing Countries

OC: Origin Country

OECD: Organisation for Economic Co-operation and Development

O-NBS: Operating a Nation-Brand Strategy

P2000: Partnership 2000

PCI: Product-Country Images

PCW: Programme for Competitiveness and Work

PESP: Programme for Economic and Social Progress

PNR: Programme for National Recovery

SCNR: Supreme Council of National Reconstruction

SFI: Science Foundation Ireland

SITC: Standard International Trade Classification

S-NBG: Setting a Nation-Brand Goal

STI: Science, Technology and Innovation

STPEM: Science and Technology Promotion Expansion Meeting

STPP: Science and Technology Promotion 5-Year Plan

STPS: Science and Technology Promotion Strategy

TNCs: Transnational Corporations

UNCTAD: United Nations Conference on Trade and Development UNDP: United Nations Development Programme

UNRISD: United Nations Research Institute for Social Development

USC: University of Southern California

USIA: United States Information Agency 


\section{CHAPTER 1 INTRODUCTION}

\subsection{RESEARCH BACKGROUND}

Nation branding, along with globalization, has become an emerging discipline combining multiple dimensions of a country's sustainability. It is considered an important way of creating and improving national development value for the quality context of human life and competitive advantage in global markets. Moreover, nation branding is a fundamental and powerful driver that enables nations to achieve their nation brand equity. Ultimately, to sustain such national values, nations need the continuing role of nation branding.

To bring clarity to the role of nation branding, we need to define why nation branding is an important domain for sustainability of nations. This epistemological view of nation branding has evolved in the marketing context on the one hand. That is, nations have been urged to transform national economic development into a marketing challenge (Kotler et al., 1997). They have been challenged to improve a nation's quality of development in order to attract and retain foreign investors, tourists and creative workers. In addition, nations have engaged themselves to earn market share and to attain premium prices in markets by representing their export products and their brands as attractive.

To sustain national development and competitive advantage both internally and externally, on the other hand, it requires nations to set these within the political context on the basis of soft power. That is, the world order has rested on more than the traditional balance of power alone as the attempts to divert the attention of the aggressor and to become more relevant to the liberal conception of a world society of peoples as well as states (Nye, 1992). The science of nation-building through soft power has become a key component of national power in maintaining the world order (Fukuyama, 2004).

In line with the contexts of marketing a nation and political activity of nation-building, most academics and practitioners readily acknowledge that nation branding is a common national practice and is often considered to be a panacea for all the problems a nation faces. However, in reality, both the economic and non-economic differences between nations have widened, generating political, cultural and social conflicts that can threaten their people. Nations are forced to position themselves based on both national identities and images of symbolic soft power. Moreover, they are challenged to create both economic and non-economic benefits for their peoples. Nation branding is considered to be a potentially powerful solution to those gaps and conflicts and to providing nations with economic, social and cultural benefits for their peoples. Yet research shows a wide range of definitions of what nation branding is and how it works to create, improve and sustain a nation's values and competitiveness. 


\subsection{RESEARCH OBJECTIVE}

A brand - a valuable intangible asset - is much more than a name, and branding is a strategy problem, not a naming problem (Webster \& Keller, 2004:389). Pickton (2008) refers to the brand as the total and ultimate expression of all the collected activities undertaken by the brand owner and the experiences of the brand user, and to branding as a managerial process in which we seek to become more economical, efficient and effective by managing the inputs and a given set of outputs. According to Louro and Cunha (2001), brands retain a significant potential to enable the achievement and sustenance of superior performance. In contemporary managerial thought, the value of a brand is thought to reside in its 'brand equity', and brand equity stands for a brand's capacity to generate a future value stream (Arvidsson, 2006). Based on these notions, the brand itself is the total and ultimate concept based on both a value and a potential. Branding is about managing a brand to achieve brand equity and to sustain superior performance outputs. Every nation is a brand and most nations have had their brands made for them (i.e. national brands) (Loo \& Davies, 2006). Nation branding is the branding of a nation and encompasses activities from country naming through to all the collected activities of the country. That is, based on the notion of branding theory in general, nation branding is to manage a nation brand as a total and umbrella concept to achieve nation brand equity and to sustain the performance outputs of a nation.

Recognizing that any nation will want to position or reposition itself as a nation with a comparative advantage over other nations, researchers into nation branding have discussed the inherent challenges. Jaffe and Nebenzahl (2006:139) advocated that a country's image should be strategically determined and consistently controlled by a branding approach. A nation's identity has been considered to be a contributor to the creation and sustenance of a distinctive competitive edge (Konecnik \& Go, 2008:177). Given those imperatives, nation branding has hitherto been considered as a managed process to build the brand identity, image and reputation (Konecnik \& Go, 2008; Loo \& Davies, 2006; Passow, Fehlmann \& Grahlow, 2005; Gnoth, 2002). These concepts of nation branding have led to the development of the concepts of nation brand equity and brand management.

To rebuild and improve their identities, images and reputations, nations have put efforts into nation branding with the help of various branding techniques. The USA, for instance, accounts for over fifty percent of the top 100 global product brands (Interbrand, 2007). Adopting a branding-based approach, since 2001 the USA government and global enterprises have been reinforcing public diplomacy in order to build international relationships with foreign audiences and to improve their reputations. As well as the USA, nations such as the UK and Germany have followed a similar track. Asian nations, since the Asian crisis in 1997, have been keenly aware of the necessity of building country images (Temporal, 2001; Pantzalis \& Rodrigues, 1999) and committed to building nation 
brands. Transitional nations that are located in Eastern Europe also have been struggling to rebuild their identities and images; these have been considered to be opportunities for "leap-frogging" into EU membership. To rebuild images as promising places for business, countries in Africa have presented new roles of providers of services, moving away from the traditional reliance on exports (Francis, 2007).

Increasingly, nations around the world are embracing nation branding to differentiate them on the world stage and to bolster their economic performance (Dinnie, 2008:23). However, as Anholt (2007a) pointed out, there has been a simplistic notion that the brand management of a nation is synonymous with creating a visual identity or a promotional campaign. Nations have, in fact, suffered limitations on building their nation brands. Some nations have focused on public diplomacy, but they are criticized for this as compromising their image and reputation. Product brands built in Asian economies, with their distinctive nation images, usually attract low prices in the market compared to the premium prices commanded by quality products and services. Reszka and Zdort (2002) found that almost $\$ 25 \mathrm{~m}$ has been earmarked for promotion of the Polish brand with little success. Foreign investment flows that represent current world economic trends and indicate financial-based competitiveness display clear economic disparities between nations. The flow of inward FDI had been concentrated on industrialized economies $(67 \%)$ rather than industrializing ones $(33 \%)$ in the 1960s. In 2003, inward FDI was $69 \%$ in industrialized nations, $28 \%$ in industrializing nations, and just 3\% in Central and Eastern Europe (Ietto-Gillies, 2005; UNCTAD, 2004). FDI inflows into developed nations grew again in 2007, which reduced the share of developing nations in FDI inflows (UNCTAD, 2008).

Nations have recognized the vital importance of developing a nation brand, and have tried to rebuild their image and reputation by relying on their own learning processes. However, nation branding is characterized by extremely complex multidimensional facets and unpredictable tasks - with multiple outputs, multiple stakeholders and multiple target nations. Researchers have argued that nation branding needs a strategic management tool for sustainable improvement rather than just a static snapshot of the brand development. To consolidate multifaceted notions into an integrated concept, they have argued that nation branding requires a holistic and systematic approach (Szondi, 2007; Gold, 2006; Mihailovich, 2006; Freire, 2005; Papadopoulos, 2004) that focuses both on reality and strategic management of the nation brand (Anholt, 2007a; Zerrillo \& Thomas, 2007; Caldwell \& Freire, 2004). However, despite the theoretical and practical importance of nation branding, the expanding body of literature has paid limited attention to how a nation brand should be managed and how nation branding can be a managed process in a holistic and systematic manner.

Moreover, to create the concept of nation branding and its role in sustaining nations' values, it is necessary to address the notions of sustainability as well as those of the brand and branding. We can extend these notions to nation branding and country management. The existing literature on branding theory argues that the brand functions as the organizing 
principle for the entire strategic process (Van Gelder, 2005), and branding is a powerful means to secure a competitive advantage (Kotler \& Keller, 2006). Meanwhile, sustainability implies a desire to maintain certain attributes and, at the same time, refers to be most effective as an organizing theme around which a nation and its subunits (such as cities and regions) in transition develop a discourse for responding to change (Hanna, 2005). Researchers have extended these to the nation-branding notion. Anholt (2005a) argued that branding is the part of the very foundations of competitiveness in a free marketplace and that any country which needs to improve its competitive edge should take a closer look at how branding works. Mihailovich (2006) asserted that branding has become a central tool in country competitiveness. In concrete terms, according to Pant (2005), the aim of branding should be to pursue substantial and holistic sustainability by turning the 'quality of context' into 'competitive advantage' in international business (Pant, 2005). However, even though the literature in nation branding has emphasized a nation's brand and branding with respect to competitive advantage and sustainable development contexts, there has been little attention paid to explaining the relevance of nation branding with respect to the sustainability and competitiveness of nations.

In particular, to contend that a nation brand is the organizing principle for the country's strategic process and nation branding is a powerful engine for achieving the country's competitive advantage, it is necessary for nation branding to align a nation brand with the whole process of country management. That is, branding needs to start with a clear point of view of what an organization should be about and how it will deliver sustainable competitive advantage (Clifton, 2004:2). Farquhar (2005:96) asserted that there is a persistent need for improving brand alignment within organizations. It is also true that such need poses difficult challenges for managing the organization and its strategic brand (Ibid). The nation brand must be an organizing principle at the heart of the country. Nation branding needs to provide nations with the principle of how nations can sustain their values against change so as to achieve competitiveness both internally and externally. It is essential to consider how a nation brand can be effectively managed to achieve nation brand equity.

Given the imperatives, this research highlights the importance of explaining how nation branding plays a role in creating and managing the nation brand and, particularly in terms of sustainability and brand alignment notions, how nation branding aligns the nation brand as a source of a nation's competitiveness with country management. The objective of this research is expressed as follows: to assess the role of nation branding and create a strategic management tool on nation branding for the sustainable competitiveness of nations. 


\subsection{PROBLEM STATEMENT}

This research aims to define the role of nation branding and create a strategic management tool on nation branding for the sustainable competitiveness of nations. Reflecting the notions of establishing measurable performance outcomes (Papadopoulos, 2004) and the effective nation branding as the most critical challenge in branding nations (Szondi, 2007), we highlight the importance of explaining performance in nation branding.

In general, performance is about how to evaluate the effectiveness, i.e. the relationship between causal variables and outcomes (Ietto-Gillies, 2005; Malina \& Selto, 2003; Wells $\&$ Wint, 2000). In the branding context, performance is measured by gauging the effectiveness of brand-building activity from brand investment through to business impact (Munoz \& Kumar, 2004). To help our understanding of performance in nation branding, this research refers to it as "the extent to which the variables in nation branding contribute to the achievement of the sustainable competitiveness of a nation as the outcome of nation branding." To date, the existing literature in nation branding lacks in providing causal relations in terms of performance in nation branding. Therefore, it is a critical challenge to explain the effective performance in nation branding, particularly in respect of the sustenance of competitiveness.

With respect to performance in nation branding, we highlight the need to take a brand management approach that will eventually result in brand value, focusing on the effectiveness of the outcomes of branding (Pickton, 2008). Considering brand alignment to the country management, moreover, we emphasize the management role in nation branding that must ensure a structured and systematic approach to the management of a nation brand. However, without an integrated system for branding, no organization can achieve optimum performance (Ryder, 2003). To bring about more holistic brands and improve the quality of life for people, we need a systematic model for strategically building brands to help grow and sustain stronger brands (De Chernatony, 2001). Modelling is a great future challenge for the study of nation branding (Nebenzahl, 2004). Research has presented models in the context of nation branding (Dinnie, 2008; Florek \& Conejo, 2007; Zerrillo \& Thomas, 2007; and so on). However, they lack in providing a satisfactory explanation of how a nation brand's elements may be integrated and managed in a complete system, and how we can understand the management role of nation branding that achieves the sustainable competitiveness of nations. Therefore, this research formulates the following research questions:

- How does nation branding contribute to the sustainable competitiveness of nations?

- How can we design a comprehensive framework for nation branding that facilitates effectively the sustainable competitiveness of a nation? 


\subsection{RESEARCH APPROACH}

Research questions defined above are considered as a theory-building challenge. Building a theory is more than just applying the techniques by which data are collected and procedures by which they are analyzed (Easterby-Smith et al., 2002).

There is a limited case of explicit theory that explains nation brand management and performance in nation branding (Szondi, 2007; Gudjonsson, 2005; Mihailovich, 2005). However, nation branding has been implicitly or explicitly explained in the contexts of national competitiveness and international business, marketing that encompasses countryof-origin, place development, and public diplomacy. Throughout these related notions, we anticipate to explain how nations have been managing to build their brand values and how their performance in nation branding needs to be replicated for achieving sustainable competitiveness.

Recognizing that a good theory is built through a research approach to building that theory, this study adopts a deductive approach to building a comprehensive framework for nation branding that facilitates effectively the sustainable competitiveness of a nation. A deductive approach - in which theories are constructed from fundamental axioms, before data are collected (Bruce, 2003:2) - is suited to building a theory in cases in which there are some explanations of phenomena or predictability of the outcomes available (Saunders et al., 2007; Collis \& Hussey, 2003).

\subsection{RESEARCH STRATEGY}

Executing the research activities and building a model are clearly connected with undertaking a research strategy. Saunders et al. (2007) stated that a research strategy is a general plan of how the research will go about addressing the research question that the study has framed, and insisted that any research strategy is affected by the research approach adopted. Verschuren and Doorewaard (1999) insisted that the most significant decision to make when constructing a technical research design is what kind of approach will be taken, and that the research strategy is the coherent body for key decisions.

To assess the role of nation branding and create a strategic management tool on nation branding for the sustainable competitiveness of nations, this research has formulated research questions (section 1.3). Based on the research objective and research questions, our study has adopted a deductive approach to building a theoretical model that explains performance in nation branding. To develop a research strategy that is relevant to a deductive approach to building a theoretical model, we highlight several fundamental notions. First, theory development requires a rich set of research materials (Glaser \& Strauss, 1967). Secondly, there are sequential stages through which a deductive research will progress, ranging from reviewing the literature, posing a hypothesis or a research 
model, collecting and analysing the data to test it and, if necessary, modifying the model in the light of the findings (Hair et al., 2007; Saunders et al., 2007; Robson, 2002). Finally, there is a research process by which the separate ingredients are combined into something meaningful, such as formulation, execution and modification (Hair et al., 2007). To undertake research in a 'systematic way', it should be based on logical relationships connecting research activities (Saunders et al., 2007).

To build a sound theory (Bacharach, 1989) in nation branding, it is suggested that a research strategy follows the sequential steps in generating a model as shown in Fig. 1. The literature provides a background to the major issues regarding nation branding on the sustainable competitiveness, which enables to develop a viable research model. Identifying a research method, collecting and analysing the data, the research model is extended.

Fig. 1 Research strategy for building a model

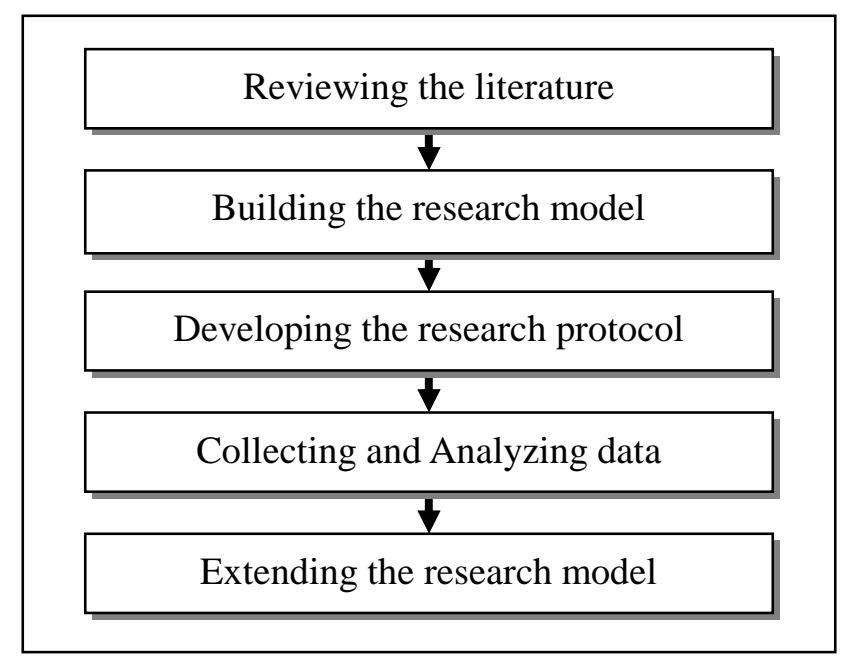

(Source: Adapted from Saunders et al., 2007; Hair et al., 2007; Robson, 2002; Bacharach, 1989)

\subsubsection{REVIEWING THE LITERATURE}

The literature review section examines recent (or otherwise historically significant) research studies that act as a basis for our proposed study (Cooper \& Schindler, 2003: 101). It is important to review the relevant literature and secondary data from comprehensive perspectives, moving to more specific studies that have a bearing on the research problem (Ibid: 102).

The existing literature that discusses nation branding has been recently extended by specific journals (e.g. Place Branding and Public Diplomacy, the Journal of Brand Management), articles, and books. To define the role of nation branding and create a strategic management tool on nation branding for the sustainable competitiveness of nations, this research investigates the relevant literature in nation branding and competitiveness contexts. 


\subsubsection{BUILDING THE RESEARCH MODEL}

In line with a deductive approach to building a theory, it is necessary to develop a clear theoretical position before moving to the collection of data (Saunders et al., 2007; Robson, 2002; Verschuren \& Doorewaard, 1999; Bacharach, 1989). A model refers to a representation of a system that is constructed to study some aspects of that system or the system as a whole (Cooper \& Schindler, 2003:55). According to researchers (Rainisto, 2003; Miles \& Hubermann 1994), the a priori framework is used to guide the empirical study and, through reformulations emerging from the empirical findings, enables us to make the theoretical perspective more explicit.

Researchers in the context of nation branding have found that nation branding is a complex and unpredictable branding process and simultaneously needs to encompass contextual variables generated within a branding process. This study defines the variables that relate to performance in nation branding and ultimately aims to develop a model that explains a causal relationship between nation branding and sustainable competitiveness of nations. Considering the necessity of building an a priori framework in a deductive approach, this research assumes that a provisional research model is imperative in order to allow data collection and to provide a solid theoretical model for a theory of nation branding.

\subsubsection{DEVELOPING THE RESEARCH PROTOCOL}

To collect data for empirical evidence, the initial model is operationalized and guidelines for empirical testing are prepared. A research protocol is an especially effective way of dealing with the overall problem of increasing the reliability of empirical testing and therefore needs to be developed and refined (Yin, 2003:57). Reliability is about whether the research would be repeatable in later studies in terms of findings and conclusions, and the goal of reliability is to minimize the errors and biases in a study before entering the field (Yin, 2003; Eisenhardt, 1989).

There is no universal way of crafting a research protocol. Some researchers adopt the perspective of data and method triangulations based on a case study protocol, and narrate the field procedure in line with maximizing construct validity. Moreover, Cooper and Schindler (2003:86) insisted that a pilot test is conducted to simulate the procedures and protocols that have been designated for data collection, and that the data-gathering phase of the research process should typically begin with pilot testing. An important notion is, as Yin (2003:67) insisted, that the protocol is more than just a questionnaire and contains not just the instrument itself but also the procedures and general rules to be followed in using that instrument. 
To refine a provisional research model through empirical evidence and then to develop a theoretical model for nation branding, a research protocol that increases reliability and construct validity is considered to be essential.

\subsubsection{COLLECTING AND ANALYZING DATA}

After establishing a research protocol, a field study follows for the collection of empirical data. After the data is collected, it is necessary to edit it to ensure consistency, so as to make a sound analysis possible. Analyzing data is at the heart of building theory, but it is both the most difficult and the least codified part of the process (Eisenhardt, 1989:539). Data analysis involves reducing accumulated data to a manageable size, developing summary measures and looking for patterns (Cooper \& Schindler, 2003:87). Moreover, it is necessary to interpret the findings in the light of the research question, explore relationships among variables and determine whether the results are consistent with the provisional research model (Ibid).

Several researchers suggest that it is necessary to consider a combined approach to conducting an empirical study. They mean that data analysis with data collection not only gives the researcher a head start in analysis but also, more importantly, allows advantage to be taken of flexible data collection methods (Eisenhardt, 1989:539). To explain causal relationships between factors or contextual variables in the provisional research model, this study takes an approach to combining data collection with analysis.

\subsubsection{EXTENDING THE RESEARCH MODEL}

The theory-building process relies on the published literature, empirical observation or experience, as well as on the insight of the theorist to build incrementally more persuasive theories (Eisenhardt, 1989:548). Superimposed upon the provisional research model that has emerged from the literature review and a deductive approach for a new perspective in nation branding, this study uses empirical testing. With empirical support from the application of analytical procedures, the provisional model is revised in the light of the newly found elements and a new model is finally developed. Through application of the revised model, this research provides recommendations for performance in nation branding in terms of both theoretical and practical approaches. 


\subsection{THESIS STRUCTURE}

In line with the research strategy, the structure of the thesis is as shown in Fig. 2.

Fig. 2 Thesis structure

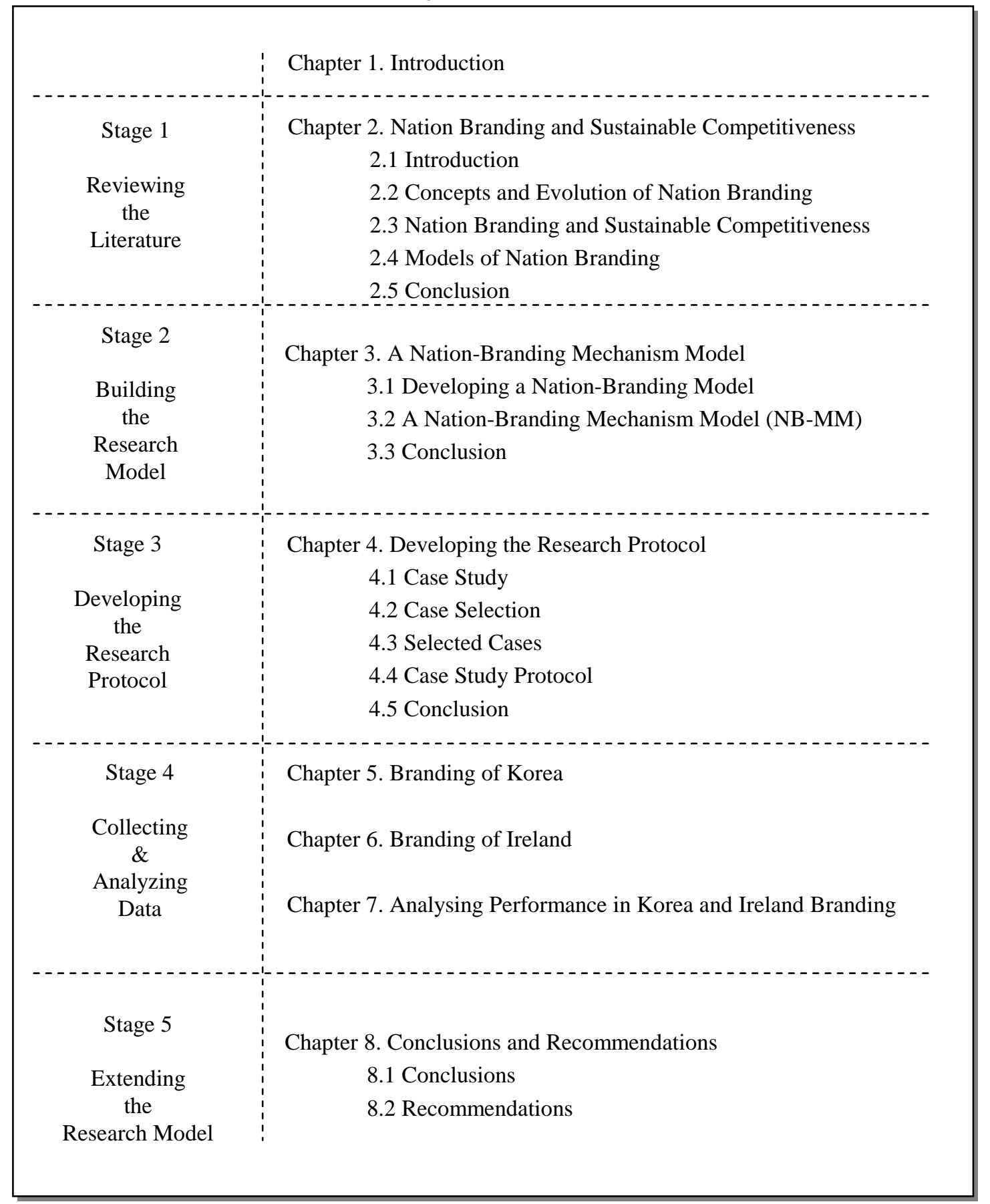




\section{CHAPTER 2 NATION BRANDING AND SUSTAINABLE COMPETITIVENESS}

\subsection{INTRODUCTION}

To provide a basis to model nation branding that contributes to the sustainable competitiveness of nations, this chapter reviews theories and models regarding nation branding and sustainable competitiveness.

To explore the variables related to performance in nation branding, we focus on the concepts and evolution of nation branding (section 2.2) and sustainable competitiveness (section 2.3). In line with those concepts, section 2.4 describes existing models relevant to nation branding and analyzes their relevance with respect to performance in nation branding and sustainable competitiveness.

\subsection{CONCEPTS AND EVOLUTION OF NATION BRANDING}

This section gives an overview of the contexts of nation branding. The first section (2.2.1) discusses the basic concepts of nation brand and nation branding. Considering that nation branding has mainly evolved within the marketing discipline, it focuses on the domains of country-of-origin (2.2.2) and place development (2.2.3), and explicates their relevance to nation branding. In addition, nation branding has combined with the discipline of international relations. Therefore, we also briefly examine the domain of public diplomacy (2.2.4). Encompassing the main discourses in those relevant contexts, this research in section 2.2.5 finally develops a key concept that relates to performance in nation branding.

\subsubsection{NATION BRAND AND NATION BRANDING}

The concept of nation branding has been implicitly or explicitly defined, ranging from notions of the nation-as-brand to considerations of nation-brand management.

In the literature, the nation-as-brand has been discussed from the etymological and the ontological perspectives of a 'nation', which relates to a nation-as-people, a nation-as-state and a nation-as-country. Etymologically, according to the Oxford English Dictionary, a nation refers to 'a large body of people united by common descent, culture or language, inhabiting a particular state or territory.' The United Nations refers to it as a human-centred state. 'Nation', 'country' and 'state' are used interchangeably in the literature of nation branding. However, Guerrini (2005) explains that the neutral idea of countries as cartographic spaces inhabited by groups of people is separated from the concept of a nation. What is important within a nation-branding discourse is that the national idea or the 
idea of nation-building comprises multiple collective identities in a single representation that might well be seen as part of the resources that form the social bond (Ibid). The nation is both a social construct and a unit with an essence, i.e. a collection of intrinsically unique characteristics (Wilder, 2007). It is accepted that a national image is very much bound up with the social concept of the nation that consists of a people sharing key elements of a common culture (values, beliefs, norms, institutions) (O’Shaughnessy \& O'Shaughnessy, 2000:56). The nation is defined through an ontological stance based on its people and salience, which drives both a nation's re-construction internally and its competition in an external globalized world. As Dinnie (2008) states, national identity thereby plays a key role in nation branding, and key issues in national identity include viewing the nation as an 'imagined community' and the notion of 'invented tradition.'

To achieve effective internal and external interactions in nation-building, moreover, cultural and historical identities should be supported and shaped by political institutions (Fukuyama, 2004:99). Governments are assumed to represent the people of a nation, and therefore, there is no getting away from the fact that nation branding is a highly politicized activity (Dinnie, 2008:200). That is, a brand identity appears to be closely linked to the national identity including a political and a cultural entity (Skinner \& Kubacki, 2007). The concept of branding a nation, therefore, relates to branding a nation-as-people, a nation-asstate, and a nation-as-country. As claimed in the 'brand manifesto' (The Medinge Group, 2002), in particular, branding should be people-oriented, focus on being meaningful to people and make people happy (whether purely functionally, emotionally, associatively or empathetically). As a result, branding a nation implies a comprehensive and holistic branding approach encompassing the notion of a human-centred state and country building.

The concept of the nation-as-brand relates to categorize the type of nations building a nation's identity and image. According to Martinovic (2002:317-18), there are three dominant types of auto-identification of countries (Fig. 3): the first domain is of innovative/post-industrial countries, which are already global leaders creating and retaining both intangible and tangible values by branding their identities; the second group of technological determined/industrial countries increases added value for export products and attracts an influx of foreign investment based on technological competency; and finally natural resources-based countries make up the group that relies on how to use their natural resources for branding. Many countries combine two or all three of these categories (Ibid). 
Fig. 3 Types of auto-identification of countries

Innovative/post-industrial countries: the countries create benefit for their goods by branding through an outstanding esteem for their general identity in the perception of global consumers

Technological determined/industrial countries: the countries compensate for their technological lag and are on the way to post-industrial status through enormous investments in education and applied science

Natural resources-based countries: the countries are presenting themselves in world's trade predominantly through marketing some of their natural resources

(Source: Adapted from Martinovic, 2002:317-18)

Categorization theory of a nation brand has also been applied in the taxonomy of country (or nation) image (Papadopoulos \& Heslop, 2002). In globalization, the same products under identical brand names are produced and designed in different countries. As a result, the country of product brands has become more significant for consumers (Leclerc et al., 1994; Samiee et al., 2005), which has led to the catagorization of countries with certain types of national image. Jaffe and Nebenzahl (2006) define, insisting that simply categorizing countries as being underdeveloped, developing or developed leads to misconceptions, the different classes of countries that are involved in shaping the images of a country and its products (Fig. 4).

Fig. 4 Country category and country image taxonomy

\begin{tabular}{|c|c|}
\hline $\begin{array}{l}\text { Designed-in Country }(D C) \\
\text { The country in which either a part of or the } \\
\text { entire finished product is designed }\end{array}$ & $\begin{array}{l}\text { Designed-in Country Image (DCI) } \\
\text { The image of a country as a source for } \\
\text { designs of products }\end{array}$ \\
\hline $\begin{array}{l}\text { Made-in Country }(M C) \\
\text { The country whose name appears on the } \\
\text { "made-in" label }\end{array}$ & $\begin{array}{l}\text { Made-in Country Image (MCI) } \\
\text { The image of a country as a production and } \\
\text { assembly location of products }\end{array}$ \\
\hline $\begin{array}{l}\text { Parts-in Country }(P C) \\
\text { The country that is the source of identified } \\
\text { key parts or components }\end{array}$ & $\begin{array}{l}\text { Parts-in Country Image (PCI) } \\
\text { The image of a country as a production } \\
\text { location of the product parts }\end{array}$ \\
\hline $\begin{array}{l}\text { Assembled-in Country }(A C) \\
\text { The country where final assembly took place }\end{array}$ & $\begin{array}{l}\text { Assembled-in Country Image (ACI) } \\
\text { The image of a country as an assembly } \\
\text { location of products }\end{array}$ \\
\hline $\begin{array}{l}\text { Origin Country }(O C) \\
\text { The country in which a consumer associates } \\
\text { with a certain product or brand }\end{array}$ & $\begin{array}{l}\text { Origin Country Image (OCI) } \\
\text { The overall image of a country to be } \\
\text { associated with brands or products }\end{array}$ \\
\hline
\end{tabular}

(Source: Adapted from Jaffe \& Nebenzahl, 2006:28-30) 
The concept of the nation-as-brand relates to how to define nation brand itself. Nation brand has various facets (Table 1). First, nation brand is a symbolic-oriented perspective such as a name or visual system, which is based on the American Marketing Association (AMA)'s definition. Second, it denotes the interaction between people's perceptions and national competence. Third, the notion of a nation brand is a complex of brand identity and image encompassing a nation's reality and stakeholders' perceptions. Finally, a nation brand is a dynamic entity differentiating national reality from other nations and at the same time providing relevance for the stakeholders. A clearly strong nation brand can help the 'management' of a country to create a major, long-term aim of increasing the wealth of a nation (Florek, 2005).

Table 1 Definition of a nation brand

\begin{tabular}{|c|c|}
\hline Reference & Definition \\
\hline $\begin{array}{l}\text { Kotler \& Gertner } 2002 \\
\quad \text { Cho } 2004\end{array}$ & $\begin{array}{l}\text { A name, related terms, marks, symbols, design or combined all to differentiate } \\
\text { them from other countries }\end{array}$ \\
\hline Anholt-GMI 2004 & $\begin{array}{l}\text { The sum of people's perceptions of a country across national competence such } \\
\text { as the cultural, political, commercial, tourist appeal, investment potential and } \\
\text { human assets }\end{array}$ \\
\hline Szondi 2007 & A sort of umbrella under which further sub-brands can be developed \\
\hline Walsh \& Wiedmann 2008 & $\begin{array}{l}\text { A very complex brand identity that is the result of a specific national reality, its } \\
\text { perceptions and evaluations by many different internal and external stakeholders } \\
\text { (brand images), and a specific overall reputation }\end{array}$ \\
\hline Dinnie 2008 & $\begin{array}{l}\text { The unique, multi-dimensional blend of elements that provide the nation with } \\
\text { culturally-grounded differentiation and relevance for all of its target audiences }\end{array}$ \\
\hline
\end{tabular}

Nation branding, as shown in Table 2, is a way of establishing 'nation brand value as the total sum of nation brand equity.' It specifies management both to develop a nation's attraction and to project an attractive image in a coherent manner. In particular, nation branding aims to set the strategic approach that applies to innovating the economic, social, political and cultural realities and to align that approach to a strategy for improving national reputation and image.

Based on the concepts of nation branding, nation branding is mostly conceptualized as a way to achieve 'nation brand equity and competitiveness.' It needs a strategic management approach to innovating a nation's realities and aligning them with improving a nation's identity and image. Anholt refers to nation branding: the systematic process of aligning the actions, behaviours, investments, innovations and communications of a country around a clear strategy for achieving a strengthened competitive identity. It can be as modest as linking the promotions [...], or it can be a decades-long policy of coordinating all internal and external national strategies [...] into a coherent, planned process. (Anholt, 2007c). In particular, this research advocates nation branding to be a systematic and planned process. This process is to be managed by a strategic approach to 
creating and improving a nation's realities, identity and image. Branding actors are considered in the branding process.

Table 2 Definition of nation branding

\begin{tabular}{|c|c|}
\hline Reference & Definition \\
\hline Olins 1999 & To build or remould national identities \\
\hline Gnoth 2002 & $\begin{array}{l}\text { To endow the audiences distinctively with expressive and affective meaning, relying on } \\
\text { managing industry system, networks, brand attributes, and their dissemination }\end{array}$ \\
\hline Hall 2002 & To re-image national identity \\
\hline Lodge 2002 & To set the strategic approach and support it from organizations \\
\hline Rendon 2003 & $\begin{array}{l}\text { To help countries to develop and communicate strong brand identities which could help } \\
\text { speed up development by attracting foreign investors and tourists }\end{array}$ \\
\hline Cho 2004 & $\begin{array}{l}\text { To establish nation brand value, the total sum of nation brand equity, through the } \\
\text { activities of the government, corporations, NGOs and people }\end{array}$ \\
\hline Dzenovska 2005 & $\begin{array}{l}\text { To discover and invent the truth about the nation that could form the basis of the } \\
\text { country's brand identity } \\
\text { To align the way the nation and its subjects think of and conduct themselves with the } \\
\text { logic of the 'reality of globalization' }\end{array}$ \\
\hline $\begin{array}{c}\text { Kyriacou \& } \\
\text { Cromwell } 2004\end{array}$ & $\begin{array}{l}\text { To consider both domestically internal development and successful integration into the } \\
\text { world community, on all levels of a nation }\end{array}$ \\
\hline O’Donovan 2004 & $\begin{array}{l}\text { To apply a brand strategy to the economic, social, political and cultural development of } \\
\text { countries }\end{array}$ \\
\hline Florek 2005 & $\begin{array}{l}\text { To create the country communication as a final-stage activity, to which belong slogans, } \\
\text { national themes, advertising, public relations, feature films and documentaries, websites, } \\
\text { etc. }\end{array}$ \\
\hline $\begin{array}{l}\text { Loo \& Davies } \\
2006\end{array}$ & $\begin{array}{l}\text { To manage all individual images into a coherent whole and project a clear and attractive } \\
\text { image that meets the needs of most of the nation's different outputs }\end{array}$ \\
\hline Anholt 2007a & To align the innovation to a strategy for enhancing national reputation \\
\hline Szondi 2007 & To promote economic, commercial and political interests at home and abroad \\
\hline Widler 2007 & To practice by the citizens and thereby contribute to re-construction of the country \\
\hline $\begin{array}{l}\text { Wilkin-Armbrister } \\
2008\end{array}$ & To acquire global recognition and achieve global competitiveness \\
\hline
\end{tabular}

Nation branding has emerged as a practice as countries turn to brand management techniques in order to compete effectively on the world stage (Dinnie, 2008:21). Brand management is concerned with planning, governance or the economic development of a nation (Anholt, 2008:23). Nations refigure the nation itself in a particular way. However, in management process, there are the ways of acting that nation branding constitutes and the practices of those who are actively involved in nation branding (Dzenovska, 2005). That is, the internal branding aspects should be thoroughly researched, i.e. to research 'how to get the populace behind it and make them "live the brand"" (Anholt, 2002a). How a country is perceived abroad is relevant to a nation's ability based on its reality (De Gouveia \& Plumridge, 2005). Nation branding thereby has to be conceptualized as an activity that involves all processes and arrangements that are geared towards supporting developments 
within national reality (Walsh \& Wiedmann, 2008). Table 3 summarizes the literature on nation branding with respect to brand management.

Table 3 Brand management in nation branding

\begin{tabular}{|c|c|}
\hline Reference & Key issues \\
\hline Gilmore 2002 & $\begin{array}{l}\text {-Effective nation branding is to build 'ownable' brand communication assets } \\
\text {-Thoughtful brand positioning gives a country a competitive advantage over other nations }\end{array}$ \\
\hline Gnoth 2002 & $\begin{array}{l}\text {-To develop the country as brand systematically, branding requires a high level of control } \\
\text { over management structure } \\
\text {-Systematic approach to the central issues of image and identity relates to manage the } \\
\text { country's product, the channel and networks }\end{array}$ \\
\hline Hall 2002 & $\begin{array}{l}\text {-Re-branding a country needs to meet the identity-building requirements placed upon its } \\
\text { national brands by the global marketplace, and those needs have been essentially set } \\
\text { within the context of intertwined political and economic considerations }\end{array}$ \\
\hline Lodge 2002 & $\begin{array}{l}\text {-Even though the principles and development of concepts in cases of nation branding are } \\
\text { similar, the 'management' contexts based on 'corporate mind' is very different }\end{array}$ \\
\hline $\begin{array}{l}\text { Martinovic } \\
2002\end{array}$ & $\begin{array}{l}\text {-Branding a nation means getting rid of all those negative labels and inventing a new one } \\
\text { that would be based on the country's real potentials and its genuine character (i.e. the key } \\
\text { features of the economic, social and cultural activities of its population) }\end{array}$ \\
\hline Olins 2002 & $\begin{array}{l}\text {-Nations have re-branded themselves on the basis of historical reality as their regimes and } \\
\text { circumstances have changed }\end{array}$ \\
\hline $\begin{array}{c}\text { Endziņa \& } \\
\text { Luņeva } 2004\end{array}$ & $\begin{array}{l}\text {-The process of a successful nation branding is determined with coordination,collaboration } \\
\text { among involved institutions, financial resources and political will }\end{array}$ \\
\hline $\begin{array}{l}\text { Dzenovska } \\
2005\end{array}$ & $\begin{array}{l}\text {-Nation branding can be seen as a practice of government through articulation of a } \\
\text { particular political rationality with corresponding technologies of government }\end{array}$ \\
\hline Florek 2005 & $\begin{array}{l}\text {-To achieve a nation's subsequent goals in the economic area, national brand strategy is } \\
\text { one of the solutions }\end{array}$ \\
\hline $\begin{array}{l}\text { Gudjonsson } \\
2005\end{array}$ & $\begin{array}{l}\text {-Nation branding integrates an economic, a social, a political and a cultural discipline, } \\
\text { which should deal with the overall planning of the nation's communication and build } \\
\text { a long-term relationship with other nations and societies }\end{array}$ \\
\hline Wetzel 2006 & $\begin{array}{l}\text {-The development of a national identity needs to be managed strategically by the } \\
\text { execution of the government and its leadership } \\
\text {-Successful nation-brand development is based on the reality of the country }\end{array}$ \\
\hline Szondi 2007 & $\begin{array}{l}\text {-In transition countries, reality is changing, and this transformation needs to take a } \\
\text { strategic approach both internally and externally driven } \\
\text {-Reality and image should always correspond in a systematic way otherwise the promotion } \\
\text { becomes 'perception management' }\end{array}$ \\
\hline Widler 2007 & $\begin{array}{l}\text {-In a nation-branding discourse, the role of citizens in the process needs to be defined } \\
\text {-The scope of nation branding needs to be figured out }\end{array}$ \\
\hline
\end{tabular}

In sum, the main aspects of 'brand management' with respect to nation branding are: to take a holistic and systematic approach; to develop the vision of the nation brand and integrate it with an economic, social, political and cultural discipline; to build brand positioning; to manage the overall planning of the nation's communication; to build a longterm relationship with other nations and societies; to develop a national identity based on 
the reality of a country; to align identity and image in a systematic way; to execute by the government and its leadership; and to build a corporate mind, involve citizens and build a brand network. These artifacts provide nation branding with an important notion of how a nation-brand development process is created in terms of a systematic and holistic approach, which can be connected to performance in nation branding.

\subsubsection{COUNTRY-OF-ORIGIN AND NATION BRANDING}

Country-of-origin (COO) research has been used for decades in the international business and marketing context, which provides nation-branding studies with a basic principle. There have been considerable publications in academic journals concerning COO (Papadopoulos \& Heslop, 2002; Peterson \& Jolibert, 1994). And so, this section focuses on exploring how $\mathrm{COO}$ research has developed over time and is linked with nation branding.

\section{COUNTRY-OF-ORIGIN}

In the chronological perspective over the period of 1965-2005 (Usunier, 2006), the concept of country-of-origin has been highlighted since the middle of the 1960s. Schooler (1965) has undertaken research to test preconceived images of products on the basis of national origin and concluded that prejudices and biases have appeared as an economic as well as a political phenomenon and the attitude toward people of a given country is a factor in existing preconceptions regarding the products of that country. Reierson (1966) has argued that consumer attitudes are national stereotypes rather than opinions about specific products. The "made in" image, according to Nagashima (1970), has been referred as the picture, the reputation, the stereotype that businessmen and consumers have attached to products from a specific country. Representative products of a country have been associated with the "made in" concept of that country (Ibid). White and Cundiff (1978) have found that perceived quality substantially has influenced buying decisions and that the manufacture of products in certain countries has been affected by a built-in positive or negative stereotype in the perception of product quality. In particular, they have suggested that such stereotypes affect the decision about where production facilities are to be located (Ibid).

Bilkey and Nes (1982) have outlined that product source countries - in terms of MDCs (More Developed Countries), MDCs vs. LDCs, and within LDCs (Less Developed Countries) - have influenced both industrial and consumer purchasing decisions. A country-of-origin image (i.e. country image) has been defined as consumers' general perceptions of quality for products from a given country. Erickson, Johansson and Chao (1984) have referred to country-of-origin as one of image variables and contrived the influences of image variables on the formation of beliefs and attitudes in line with social psychology and consumer behaviour. Johansson, Douglas and Nonaka (1985) continued 
that, to clarify the exact nature of country-of-origin effects, further research should examine both overall and attribute-specific evaluations and be based on various types of products rather than a single product. Han and Terpstra (1988) have found that both the source country and a product's brand name have affected consumer perceptions of product quality and, moreover, distinguished that sourcing-country stimuli were found to have more powerful effects than a product's brand name on consumer evaluations.

Supporting the argument that the role of country image forms a "halo" in product evaluation, i.e. general perceptions of quality for products (Bilkey \& Nes, 1982) and that such perceptions were typically specific to product categories (Hafhill, 1980; Etzel \& Walker, 1974), Han (1990) has extended the role of country image into a summaryconstruct view affecting evaluations of familiar products to consumers. Roth and Romeo (1992) have viewed country image as the overall perception that consumers form of products from a particular country, based on their prior perceptions of the country's production and marketing. Having examined $\mathrm{COO}$ in terms of the fit between countries and product categories, i.e. linking product category perceptions to country image dimensions (i.e. innovativeness, design, prestige and workmanship), Roth and Romeo (1992) have reported that a product-country match has occurred when the perceived strengths of a country were related to product characteristics and indicated potentially attractive manufacturing sites for multinational companies, and that, when favourable matches exist, consumers' willingness to buy products could be increased by promoting COO. Demonstrating that the concept of 'product-country images (PCI)' has represented a broader phenomenon than 'Country-of-Origin' or 'Made-in' concept, Papadopoulos (1993) has contended that there were some significant developments in the meaning and use of PCI identifiers over the periods of 1970s to 1980s as shown in Table 4.

Table 4 Key concepts of product-country images

\begin{tabular}{|c|c|}
\hline $\begin{array}{c}\text { 1970s } \\
- \\
\text { early of } \\
1980 \mathrm{~s}\end{array}$ & $\begin{array}{l}\text {-First, national governments began to pay more attention to "rules of origin" legislation } \\
\text { and to enforce it more carefully, as a means of protecting domestic producers; } \\
\text {-Second, both the governments and producer groups became more proactive in domestic } \\
\text { promotions of native industry, developing promotional campaigns such as "Crafted with } \\
\text { pride in the USA" or "Think Canadian"; } \\
\text {-Third, companies began to be more discriminating about the use of origin identifiers, giving } \\
\text { the emphasis on a place's unique characteristics. }\end{array}$ \\
\hline $\begin{array}{c}\text { 1980s } \\
\text { and } \\
\text { beyond }\end{array}$ & $\begin{array}{l}\text {-First, governments are becoming more proactive and systematic in promoting their image } \\
\text { abroad through joint foreign-promotion campaigns; } \\
\text {-Second, origins and their images have come under intense scrutiny in the context of trade } \\
\text { blocs; } \\
\text {-Third, the globalization of business has brought on an intense debate about the merits and } \\
\text { continuing relevance of national origin identifiers. }\end{array}$ \\
\hline
\end{tabular}

(Source: Papadopoulos, 1993) 
Convinced that country-of-origin was a potentially powerful image variable that could be used to gain competitive advantage in international marketing, Parameswaran and Pisharodi (1994) have addressed COO image as a competitive tool with a multifaceted nature. Samiee (1994) has rationalized the buying decision processes within the context of source-country influences that have elaborated with market and environmental factors. Peterson and Jolibert (1995) have attempted to quantitatively assess the COO effect by means of a type of meta-analysis, and pointed out that country-of-origin influenced perceptions and intentions in various ways, and that the influence was context-dependent. Nebenzahl, Jaffe and Lampert (1997) have insisted that in competitive markets, purchase decisions were based on relative rather than absolute levels of attributes of competitive products: as shown in Fig. 5, consumers perceive the relative images of each country and then product attributes; based on them, purchasing decisions are then made; experience of and knowledge about country image and product image create feedback, affecting country image.

Fig. 5 An information processing model of relative product image

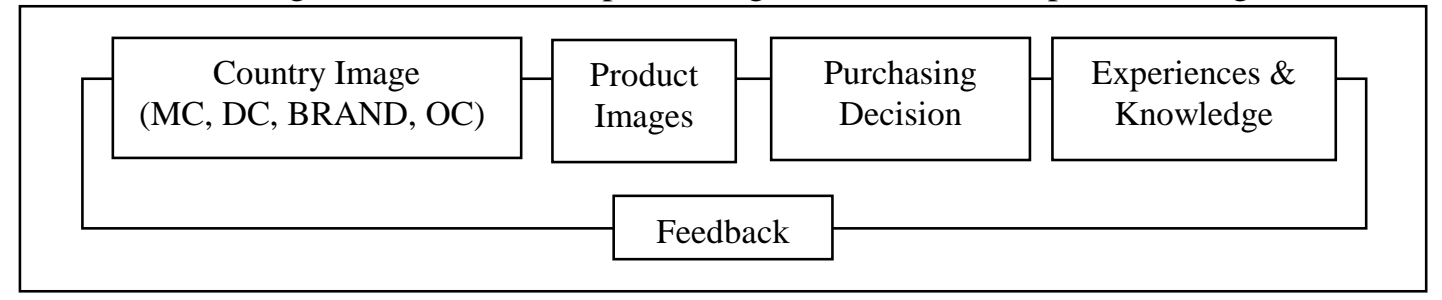

(Source: Nebenzahl, Jaffe and Lampert, 1997)

Lampert and Jaffe (1998) have pointed out the importance of country-of-origin (COO) as a dynamic process, i.e. how the $\mathrm{COO}$ effect changes over time, encompassing two-way interactions among constructs (both in product category- and country-specific ways) that change over time. Emphasizing that how image change occurring over time can be explained by a dynamic COO model, Lampert and Jaffe (1998) have found that any change in country image is a function of the respective change in the brand image and that the duration of the time interval depends on the relative marketing effort expended by the specific country-of-origin in trying to improve its image. Moreover, they (Ibid:75) have concluded that a positive (and possibly negative) country image can spill over from one product class to another, and that the boundaries for country image do not have to be confined to a specific product category. Country-of-origin effects are complex phenomena that are often caused by interplay of cognitive, affective and normative aspects. Verlegh and Steenkamp (1999) have distinguished between cognitive, affective and normative aspects of country-of-origin (Table 5). They emphasized that the study of the impact of competitive context may be broadened by examining the role of culture, technological development and natural resources, and that competitive contexts change over time (Ibid). 
Table 5 Cognitive, affective and normative mechanisms for country-of-origin effects

\begin{tabular}{|c|l|}
\hline Mechanism & \multicolumn{1}{c|}{ Description } \\
\hline Cognitive & Country of origin is a cue for product quality \\
\hline Affective & Country of origin has symbolic and emotional value to consumers \\
\hline Normative & Consumers hold social and personal norms related to country-of-origin \\
\hline
\end{tabular}
(Source: Verlegh \& Steenkamp, 1999: 524)

Considering the extent to which the notion of a brand is applicable to a nation, O'Shaughnessy and O'Shaughnessy (2000) have argued that country-of-origin is most likely to become more of a factor in high-involvement product decisions, and that many businesses buying from abroad are particularly sensitive to country-of-origin. Moreover, that study has found that target audiences are more likely to be impressed by information when a government cannot manipulate the nation's image for the purposes of deception. Chinen, Enomoto and Costley (2000) have explored the relationship between consumers' purchase intentions and their perceived product images in conjunction with political images. COO appears to have a stronger effect than product brand in consumers' evaluations toward the products. Finding out that a strong product's brand image did not overcome the perceptions of a negative COO effect, Ahmed et al. (2002) have determined that to achieve a sustainable long-term strategy, companies should try to ensure a good $\mathrm{COO}$, and that the synergy of $\mathrm{COO}$ and product-branding efforts is of managerial interest, i.e. from the brand management standpoint. Their study has been extended to examining country-of-origin effects related to organizational practices of multinational enterprises. Harzing and Sorge (2003) have investigated the relative impact of the country of origin of the multinational enterprise. They found that control mechanisms remain firmly and primarily impregnated by the country-of-origin, which provides further evidence for the existence of unique country patterns. Therefore, according to their study (Ibid), country-of-origin has come forward as one of the most important predictors of multinationals' practices at the international level.

\section{COUNTRY-OF-ORIGIN AND NATION BRANDING}

In the recent past, researchers have explored the issue and necessity of building the notions of nation brand and nation branding in greater detail. Papadopoulos and Heslop (2002) have pointed out that, while the vast majority of PCI (Product-country images) studies have asked respondents to assess the products of various countries, the image of the original countries themselves, as distinctive from their products, has not been measured explicitly. They asserted that the traditional 'made-in' or 'country-of-origin' concept has moved to a new, broader level of 'branding a country', and suggested approaches for strategy development. Kotler and Gertner (2002) have argued that country names amount to product brands and help consumers to evaluate products and that, beyond serving as brand names, countries must embark on a more conscious nation branding using a strategic 
management approach. Reflecting on the impact of country-of-origin on consumer attitudes, moreover, Kotler and Gertner (2002) have insisted that a country's reputation constitutes a vital asset that needs to be managed effectively.

Jaworski and Fosher (2003) have claimed that a nation's essence and core values give rise to a nation's brand identity and that its effect impacts on corporate brands, drawing a cycle of nation-brand building. That is, brand identity of country-of-origin is developed through nation branding, which affects everything from positioning and differentiation to purchasing decisions (Ibid). Anholt (2003) has showed how branded exports and companies combine with nation branding and how they can accomplish economic development for emerging markets, using country-of-origin more creatively. In particular, Anholt (2003) has pointed out the critical role of government in undertaking a comprehensive nation-branding programme. Papadopoulos (2004) has highlighted the point of intersection between the traditional notion of PCI (product-country image) and the new area of systematic place marketing, and addressed the convergence between these two fields through a major new development that is likely to have a significant impact both on markets and on the roles of business and government managers. Anholt and Hildreth (2005:165) have mentioned that the reassurance of value or quality which we get from 'made in' labels really is only symbolic. The country-of-origin effect is just one aspect of much bigger and more complex branding phenomenon, and countries behave like brands in many other ways (Ibid).

Gudjonsson (2005) has addressed that nation branding is about influencing and creating an effective environment for a nation's brands to compete in the markets. Countryof-origin is not the only task of nation branding, but the latter is widely seen as a 'countryof-origin' practice (Ibid). 'COO effect' or 'country image' is an external nation-brand effect through nation branding, which can be actively managed and modified (Amine \& Chao, 2005). National brands could be virtuous for developing economies, and branding facilitates and develops market access for offerings from nations in such economies (Abimbola, 2006). All nations have respective images and, through branding, attempts are made to mould, modify, or influence the shaping of these images (Jaffe \& Nebenzahl, 2006). Moreover, it is cardinal to considering how countries, industries and firms manage nation image along with products (Ibid).

There is an interaction between the nation brand and product brands, with each complementing the other, and leveraging the nation brand as a point of differentiation is one way for corporate/product brands to enhance competitiveness (Loo \& Davies, 2006). To date, no researcher has measured the impact of a country-of-origin cue in a genuine purchase situation on a specific, low-involvement product (Hamlin \& Leith, 2006). Through the field test, moreover, it is noted that the presence of a country-of-origin cue causes the recall of a strong and relatively stable multi-dimensional evaluation heuristic (Ibid). In the global marketplace, in particular, a nation brand should ideally act as a national umbrella brand, seeking to differentiate the country's products from those of 
international competitors and promoting a nation's image to an international audience (Fan, 2006:9). Even though nation branding has all types of techniques, technologies and media at its disposal, according to Fan (2006), it also faces a number of unique challenges. First, national identity is notoriously difficult to define. Second, it is about how to develop a core message about a country that can be used by different industry sectors. Third, it needs to consider the time dimension of the nation brand. Finally, in addition to the external international audiences, stakeholders in the branding campaign are important as the internal audience.

While the key issue surrounding country image has long been envisaged as a relation between product and origin (Product-Country-Image or Country-of-Origin), current branding research touches on all the characteristics of a country, i.e. the geographic, political, economic and socio-cultural aspects of a country, and takes into account the characteristics of both the product and the producer (Pasquier, 2008:81). With respect to the particular relevance of $\mathrm{COO}$ to nation branding, a coordinating body has been established to help ensure that COO perceptions of a country are tracked and effectively managed (Ibid). Examining the concept of the $\mathrm{COO}$ effect in the context of nation branding, Dinnie (2008) has asserted that COO perceptions can change over time and it is the role of nation branding to ensure that such changes evolve in a favourable direction (Ibid:101).

\subsubsection{PLACE DEVELOPMENT AND NATION BRANDING}

"A focus on the 'Made-in' images of products", Papadopoulos (1993) has indicated, "does not mean that one should think of country images in the sense of "Made-in" product labels alone." According to him, "product" can mean not only goods and services but also countries marketing themselves as attractive locations (i.e. places from a city to a state or province, a country, a region, a continent or a world) and geographic destinations for tourism or foreign investment (Ibid). Combining place and economic development notions within a strategic marketing context, Kotler, Haider and Rein (1993) have introduced the concept of place development. It is widely accepted that competitive advantage in a global economy depends on place and its economic development (Clark, 2002; Castells \& Susser, 2002; Porter, 2001; Castells, 1996). Based on their notions, the researches have discussed nation branding in line with place development and branding contexts.

\section{PLACE DEVELOPMENT}

Place has corresponded with the market conditions. Facing fundamental questions about how places can survive and adapt to growing competition, Kotler et al. (1993) suggested the ways in which place can respond to the market challenges (Table 6). In order to seize market opportunities and sustain a place's vitality, that place needs to establish a 
strategic vision and market-oriented strategic planning process, to build qualified programs to communicate and promote its competitive advantage, and ultimately, to develop mechanisms or unique change processes for adapting flexibly to changing conditions.

Table 6 Place responding to market challenges

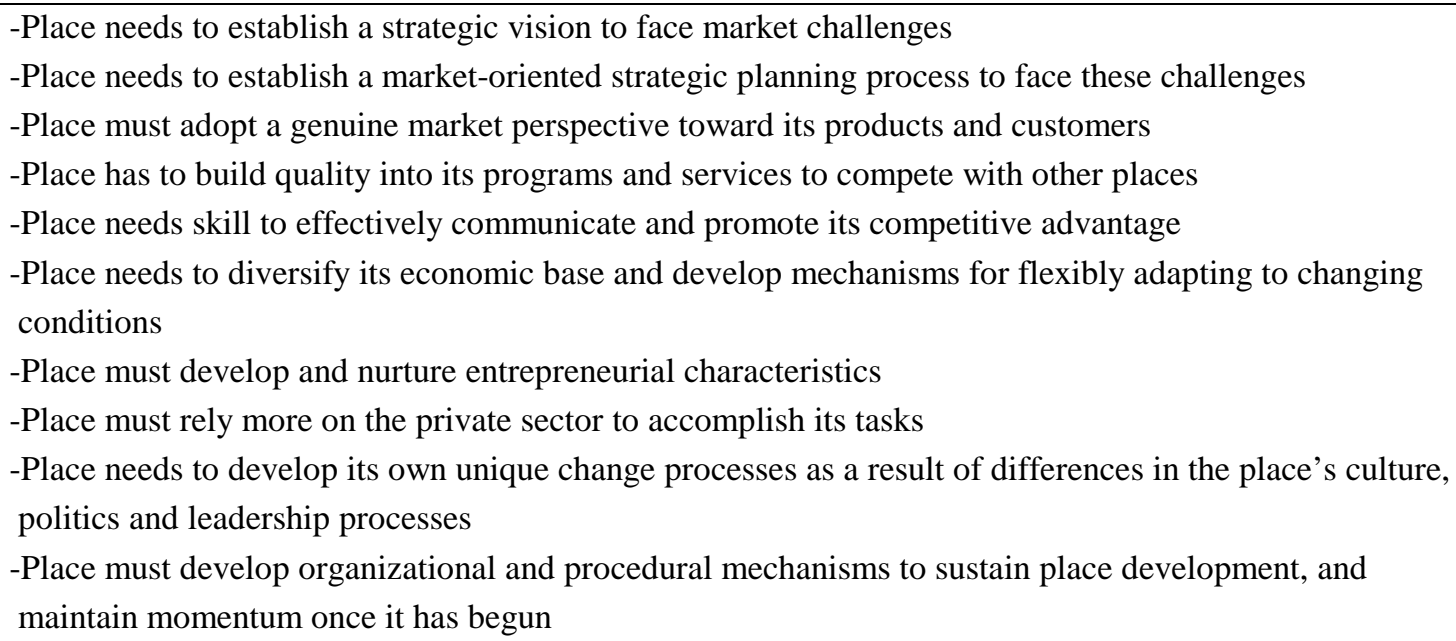

Place development reflects an ongoing struggle to accommodate market innovations while preserving historic traditions and values (Pryor \& Grossbart, 2007:298). Kotler, Haider and Rein (1993:72) have enumerated five time-honored approaches to place development (Fig. 6): the basic idea of community development and urban design is for the people currently living and working in the community; urban planning is to evaluate the community's economic base and to protect the "public interest"; economic development suggests not only more output but also different kinds of output, more productive use of resources and greater innovation, and furthermore it focuses largely on helping a place enhance its competitiveness. Underlying all these approaches is the idea that place, if it is to succeed, must use the tools of business; thereby, place must develop and operate a planning methodology (i.e. strategic market planning) (Ibid). Economic planning development strategies have focused on building a competitive advantage for a location (Borja \& Castells, 1997; Sanchez, 1997). Strategic market planning is a comprehensive approach to incorporating perspectives from community development to economic development. 
Fig. 6 Five time-honored approaches to place development

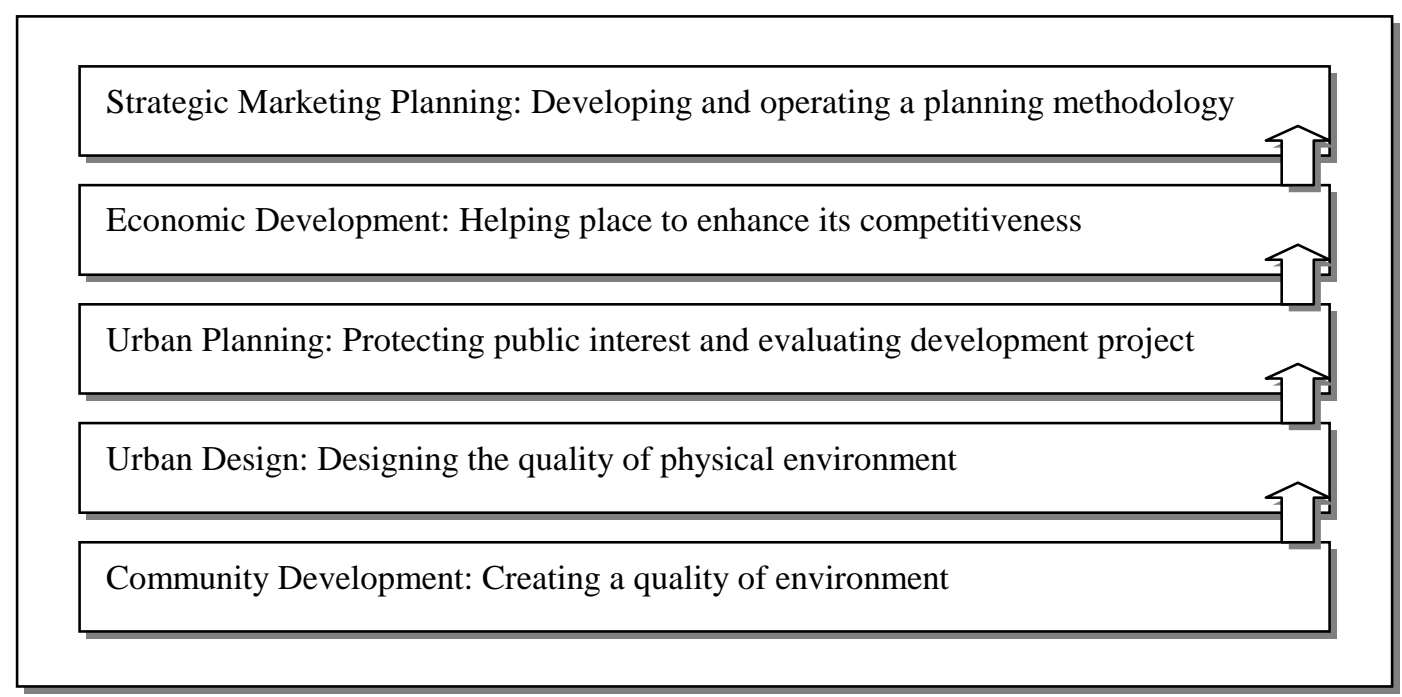

(Source: Adapted from Kotler et al., 1993:72)

Place has become more business-like and market-oriented in its economic development activities, and place marketing has emerged as a promising, integrating process linking a place's potential competitive advantage to overall economic development goals (Kotler et al., 1993:79). According to Ashworth and Voogd (1994:43), place marketing needs to consider aspects of resource production, a set of marketing measures (i.e. promotional, spatial/functional, organizational practices) for the market, and many different groups of consumers for different demands. To conduct strategic place marketing successfully, place needs major elements - planning group, marketing factors (infrastructure, attractions, image and quality of life, and people) and target markets (Kotler et al., 1993).

It is a very important strategic decision for a place to start systematic place marketing, and a decision to create a common place's marketing programme requires all parties to agree about the common goals (Rainisto, 2003:34). To explain success in place marketing practices, Rainisto (2003) has presented a framework (Fig. 7) linked together with the perspectives of the practices and the success factors. The practices are divided into three sub-groups of events, namely the events in place marketing practices, the events in the network and the events in the macro-environment. The five success factors ("Planning group", "Vision and Strategic analysis", "Place identity and Place image", "Public-private partnerships" and "Leadership"), which are situated inside the "prism" of the framework, represent abilities which place can actively influence. Another four factors are also considered to be essential. In particular, "global marketplace" gives places a vast new potentially increasing global competition, and "political unity" relates to the management of the process of the necessary decisions in a rational and consistent way. 
Fig. 7 Success factors in place marketing

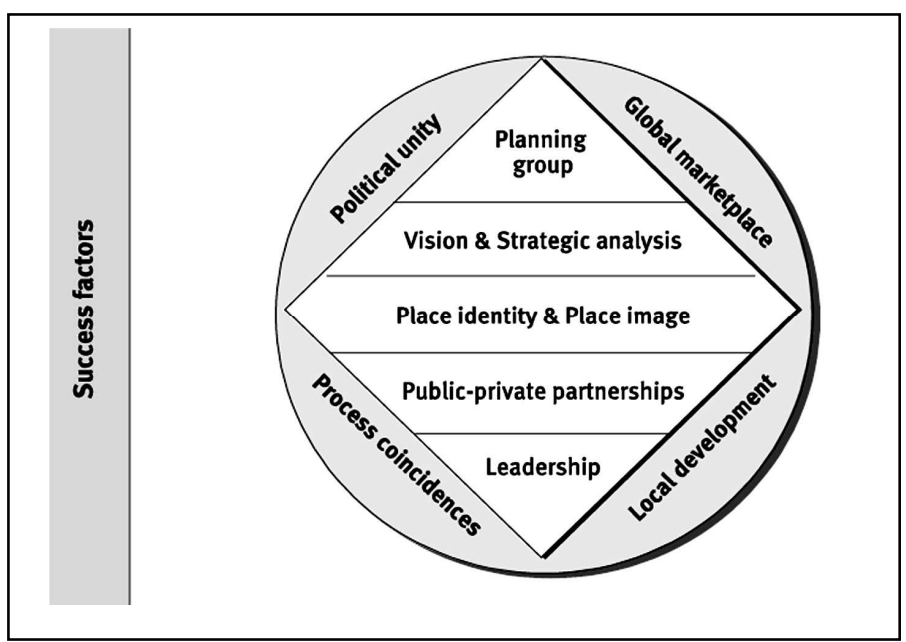

(Source: Rainisto, 2003:68)

The challenge of place marketing is to strengthen the capacity of places to adapt to the changing marketplace, seize opportunities, and sustain their vitality (Kotler et al., 1993:18). Strategic market planning aims to prepare plans and actions that integrate the place's objectives and resources with its changing opportunities (Ibid). The strategic planning process (Fig. 8) can work in most communities where institutions and procedures exist to make decisions about a place's future (Kotler et al., 1993:80).

Fig. 8 Strategic market planning process

\begin{tabular}{|c|}
\hline$\frac{\text { Conducting the Place Audit }}{\text {-Analyzing the place's strengths, weakness, opportunities and threats }}$ \\
\hline $\begin{array}{l}\text { Setting the Vision and Objectives } \\
\text {-Choosing a vision (e.g. "managed growth") } \\
\text {-Deciding on objectives (e.g. "to attract high-tech industry") } \\
\text {-Setting goal statement (e.g. "Attract four or more high-tech companies } \\
\text { to move their headquarters to San Diego with the aim of creating } 300 \text { new } \\
\text { jobs by December 1994") }\end{array}$ \\
\hline $\begin{array}{l}\text { Formulating the Strategy } \\
\text {-Identifying and choosing strategies for accomplishing the goals } \\
\text { "Establishing a high-tech industrial park" } \\
\text { "Identifying some European high-tech companies and inducing them" }\end{array}$ \\
\hline $\begin{array}{l}\text { Developing the Action Plan } \\
\text {-Listing actions along with four additional components, such as who is } \\
\text { responsible, how the action is to be implemented, how much the action } \\
\text { will cost, and the expected completion date }\end{array}$ \\
\hline $\begin{array}{l}\text { Implementing and Controlling the Marketing Plan } \\
\text {-Implementing the marketing plan } \\
\text {-Reviewing the place's progress towards its goals }\end{array}$ \\
\hline
\end{tabular}

(Source: Adapted from Kotler et al., 1993:81-98) 


\section{PLACE DEVELOPMENT AND BRANDING}

There is no single accepted definition of branding a place. However, its concept has been established and practiced consciously or unconsciously through the place development context of marketing (i.e. place marketing). Researchers have investigated some similarities or differences between place marketing and branding, and these reflect how the concept of nation branding has evolved.

Kotler and Gertner (2002) have articulated that the need to attract tourists, factories, companies and talented people and to find markets for their exports requires for the countries to adopt strategic marketing management tools and conscious branding. That is, strategic place marketing primarily concerns the enhancement of a country's position in the global marketplace and, therefore, it requires management of the different tasks [emphasized by author] of country brand - managing the image and attracting tourists, factories and companies (Ibid). When a place manages to create favourable brand associations in the minds of the targeted customers, a place brand has been born and there is a chance that the customer will select the place to be "consumed" (Rainisto, 2003:49). The process creating a benefit for "place customers" requires a good development system for the place product so that a place-oriented value-added can be made "visible" (Ibid). With respect to place marketing, strategic image management (SIM) is highlighted as the ongoing process of researching a place's image among its various audiences, segmenting and targeting its specific audiences, positioning a place's attractions to support its desired image and communicating those attractions to target groups (Gertner \& Kotler, 2004).

However, supporting the difference between the image-formation process and its branding (Cai, 2002), Konecnik (2004) has pointed out that image formation is not branding, albeit that the former constitutes the core of the latter, and highlighted that there have been no great efforts to distinguish between the image and branding functions, in particular, for brand identity. Classifying branding concepts from the place marketing literature (Table 7), moreover, Hankinson (2004) has highlighted that brands as perceptual entities (i.e. brand image or perceptual perspectives) have dominated the most established view that the role of marketing is to promote an image in order to help achieve social and economic goals. 
Table 7 Brand conceptualisations from the place marketing perspective

\begin{tabular}{|c|c|c|c|}
\hline $\begin{array}{l}\text { Brands } \\
\text { As perceptual entities }\end{array}$ & $\begin{array}{c}\text { Brands } \\
\text { as communications }\end{array}$ & $\begin{array}{l}\text { Brands } \\
\text { as relationships }\end{array}$ & $\begin{array}{c}\text { Brands } \\
\text { as value enhancers }\end{array}$ \\
\hline $\begin{array}{l}\text { Woodside \& Lyonski } 1989 \\
\text { Echtner \& Ritchie } 1991 \\
\text { Echtner \& Ritchie } 1993 \\
\text { Walmsley \& Jenkins } 1993 \\
\text { Young } 1995 \\
\text { Walmsley \& Young } 1998 \\
\text { Nickerson \& Moisey } 1999 \\
\text { Leisen } 2001\end{array}$ & $\begin{array}{l}\text { Hall } 1999 \\
\text { Morgan et al., } 2002 \\
\text { Kotler \& Gertner } 2002 \\
\text { Pride } 2002 \\
\text { Gnoth } 2002\end{array}$ & $\begin{array}{l}\text { Westwood et al.,1999 } \\
\text { Sirgy \& Su 2000 } \\
\text { Morgan et al., } 2002 \\
\text { Kotler \& Gertner } 2002\end{array}$ & $\begin{array}{l}\text { Thode \& Msulka } \\
1998 \\
\text { Westwood } 2000\end{array}$ \\
\hline
\end{tabular}

(Source: Hankinson, 2004: 113)

Papadopoulos (2004:42) has pointed out that place marketing has been practiced independently in various different contexts (such as the promotion of exports, FDI, or tourism). Moreover, he insisted that there is an emerging phenomenon that public sectors at the national and local levels integrate those contexts into a consistent 'place brand' and the public and private interests in marketing place images converge (Ibid). Branding a country is not the same as promoting tourism, which is only one component of nation branding (Anholt, 2004). That is, nation branding also involves other factors such as 'stimulating inward investment and aid, encouraging both skilled and unskilled workers to immigrate, promoting the country's branded and unbranded exports internationally, increasing the international business of the national airline, facilitating the process of integration into political and commercial organizations such as the European Union' (Ibid).

Place branding needs encompassing not only as a designed visual identity (e.g. name, logo, slogan, corporate livery and so on), but also in a wide area of corporate strategy, consumer and stakeholder motivation and behaviour, internal and external communications, ethics, and purpose (Anholt, 2005:117-18). Place branding should be practiced through a harmonised and strategically informed approach to the promotion of place's 'products' and 'sub-brands' and establish its overall reputations built by a place's actions or behaviors that are guided by strategy (Ibid). Place branding, along with the place marketing discipline, has been referred to as 'the practice of applying brand strategy and other marketing techniques and disciplines to the economic, social, political and cultural development of cities, regions and countries' (The Journal of Place Branding and Public Diplomacy ${ }^{1}$ ). However, Pryor and Grossbart (2007) have insisted that this definition has only described the marketing of places and it is insufficient for the development of theory related to place branding. They have referred to place branding as 'the process of inscribing to a place symbols and images that represent that set of central, enduring, and distinctive characteristics that actors have ascribed to that place, thereby creating a focus of identity' (Pryor \& Grossbart, 2007:294).

\footnotetext{
${ }^{1}$ http://www.palgrave-journals.com/pb/index.html
} 
There are at least three different types of place branding (Table 8), which are really quite different operations conducted by different types of producers for brand identity with widely different objectives (Kavaratzis \& Ashworth, 2005). First, in terms of geographical nomenclature, a place becomes only a name for a specific brand or, in other instances, a generic name for a production process. Second, product-place co-branding is about using the qualities of local products to ascribe meanings and associations to the place. Third, place branding can be treated as a form of place management, which is based on the notion that the creation of a recognizable place identity and the subsequent use of that identity to further other desirable processes can change user behaviour. The typology is beginning to move away from the first category towards the second and third especially (Ibid).

Table 8 Typology of place branding

\begin{tabular}{|c|l|}
\hline $\begin{array}{c}\text { Geographical } \\
\text { Nomenclature }\end{array}$ & $\begin{array}{l}\text {-A physical product is named for a geographical location } \\
\text { (e.g.The archetype is the sparkling wine 'Champagne') } \\
\text {-There is no conscious attempt to link any supposed attributes of the place to the } \\
\text { product, which is only an historical-geographical accident }\end{array}$ \\
\hline \multirow{3}{*}{$\begin{array}{l}\text {-Attempt to market a physical product by associating it with a place that is assumed to } \\
\text { have attributes beneficial to the image of the product (e.g. 'Swiss watches') }\end{array}$} \\
Co-branding & $\begin{array}{l}\text {-This is a different use of place nomenclature than 'Champagne' because the objective } \\
\text { is to transfer characteristics of reliability, fastidiousness and meticulousness assumed } \\
\text { to be associated with the Swiss people or the country Switzerland, to watches for which } \\
\text { these are assumed to be desirable attributes }\end{array}$ \\
\hline Management & $\begin{array}{l}\text {-Changing the way places are perceived by specified user groups } \\
\text { (e.g. urban renewal including the creation of an identity with its own experiential } \\
\text { value) } \\
\text {-Touches upon such points as structure, programming, functions, the sort of actions } \\
\text { and activities that characterize the image of the city, events and in the last resort the } \\
\text { chemistry of the people who operate there (Florian 2002:24) }\end{array}$ \\
\hline
\end{tabular}

(Source: Adapted from Kavaratzis \& Ashworth, 2005)

Brand management in place development and branding (Table 9) has been discussed in the emerging literature. Researchers focus on brand management strategy and processes such as: brand essence, a vision and visionary leadership, positioning strategy, implementation and branding actors; the relationship between branding actors, the economic development policies and economic growth; stakeholder relationship; brand architecture as a 'nation umbrella brand' and its sub-brands; branding, sustainable development and a brand management system; an interdisciplinary and holistic approach; strategic innovation and coordinated policy; an agreed single national identity; the reality of the core brand; and place image for place (or country) equity. However, despite the expanding body of literature, very little has been written about how place marketing and, in particular, branding of places should be holistically managed (Hankinson, 2007:241). 
Table 9 Brand management in place development and branding

\begin{tabular}{|c|c|}
\hline Reference & Key issues \\
\hline $\begin{array}{l}\text { Morgan, Pritchard } \\
\text { \& Piggott } 2002\end{array}$ & $\begin{array}{l}\text {-Process involved in successful brand building includes researching the brand values, } \\
\text { vision, positioning strategy and implementation, which enables to achieve celebrity } \\
\text { status and emotional value }\end{array}$ \\
\hline $\begin{array}{l}\text { Papadopoulos \& } \\
\text { Heslop } 2002\end{array}$ & $\begin{array}{l}\text {-Whether branding is appropriate to countries as a strategy or not is based on the } \\
\text { theory that a common desire for economic growth can motivate various actors in a } \\
\text { place towards a concensus regarding the economic development policies it adopts }\end{array}$ \\
\hline Rainisto 2003 & $\begin{array}{l}\text {-Place branding brings added attraction to a place, the central issue being to build } \\
\text { the brand identity of a place }\end{array}$ \\
\hline Hankinson 2004 & $\begin{array}{l}\text {-The ultimate success of a place branding strategy relies on the effective extension } \\
\text { of the reality of the core brand through effective relationships with stakeholders }\end{array}$ \\
\hline $\begin{array}{l}\text { Morgan \& Pritchard } \\
2004\end{array}$ & $\begin{array}{l}\text {-For a brand to be genuinely successful, the vision has to be reflected in brand- } \\
\text { building, creating a public-private partnership to reposition the country on the } \\
\text { world stage and maintaining brand's essence }\end{array}$ \\
\hline $\begin{array}{l}\text { Papadopoulos } \\
2004\end{array}$ & $\begin{array}{l}\text {-The growing realization that place image must be systematically marketed can } \\
\text { be encapsulated in the concept of 'place (or country) equity' } \\
\text {-The emerging situation has major implications for, and presents significant } \\
\text { challenges to, all the actors (from governments to private sectors) involved }\end{array}$ \\
\hline Blichfeldt 2005 & $\begin{array}{l}\text {-What branding can do for places is that it offers an excellent opportunity for } \\
\text { diagnosing what dimensions of place brands are good, bad or irrelevant from the } \\
\text { visitor's point of view }\end{array}$ \\
\hline $\begin{array}{l}\text { Dooley \& Bowie } \\
2005\end{array}$ & $\begin{array}{l}\text {-Brand architecture (i.e. 'nation umbrella brand' and its sub-brands) in the context of } \\
\text { place branding is useful }\end{array}$ \\
\hline Freire 2005 & $\begin{array}{l}\text {-Branding applied to places is a result of changes in society and an intelligent answer } \\
\text { for local sustainable development } \\
\text {-Place should develop a brand management system }\end{array}$ \\
\hline $\begin{array}{l}\text { Kerr \& Johnson } \\
2005\end{array}$ & $\begin{array}{l}\text {-Brand management strategy of a place needs to be well resourced, particularly in } \\
\text { terms of leadership, funding, and commitment on the part of key stakeholders }\end{array}$ \\
\hline Pant 2005 & $\begin{array}{l}\text {-Creating such a place brand strategy calls for interdisciplinary research and } \\
\text { planning to design an imaginative economic policy } \\
\text {-A strong political will to implement brand strategy } \\
\text {-Aiming to pursue a substantial and holistic sustainability by turning the 'quality of } \\
\text { context' into competitive advantage in international business }\end{array}$ \\
\hline Gold 2006 & $\begin{array}{l}\text {-To manage a place brand is to both develop and manage a place's intellectual } \\
\text { architecture which gives rise to the brand }\end{array}$ \\
\hline Kerr 2006 & -The more holistic approach to place brand management is gaining interest \\
\hline Lodge 2006 & $\begin{array}{l}\text {-Holistic place branding (encompassing everything a place wishes to sell) is on its } \\
\text { way to becoming recognized as a necessary tool for economic growth }\end{array}$ \\
\hline Mihailovich 2006 & $\begin{array}{l}\text {-Nation branding should develop a sustainable brand architecture (i.e. the different } \\
\text { levels of branding within a place) and an holistic management system }\end{array}$ \\
\hline Anholt $2007 b$ & $\begin{array}{l}\text {-Place branding is the management of place image through strategic innovaton } \\
\text { and coordinated economic, commercial, social, cultural and government policy }\end{array}$ \\
\hline $\begin{array}{l}\text { Gould \& Skinner } \\
2007\end{array}$ & $\begin{array}{l}\text {-Place branding is a method of promoting a positive image based on an agreed } \\
\text { single national identity }\end{array}$ \\
\hline Hankinson 2007 & $\begin{array}{l}\text {-For the management of place brands, there are five guiding principles: visionary } \\
\text { leadership; a brand-oriented organizational culture; departmental coordination and } \\
\text { process alignment; consistent communications and partnerships across stakeholders }\end{array}$ \\
\hline $\begin{array}{l}\text { Pryor \& Grossbart } \\
2007\end{array}$ & -Multiple stakeholders may concretely influence place development \\
\hline $\begin{array}{l}\text { Skinner \& Kubacki } \\
2007\end{array}$ & $\begin{array}{l}\text {-The place's brand identity is inextricably linked with the place's national identity } \\
\text { that is rooted in both culture and politics and does change over time }\end{array}$ \\
\hline $\begin{array}{l}\text { Zerrillo \& Thomas } \\
\qquad 2007\end{array}$ & $\begin{array}{l}\text {-As developing nations transit from one economic phase to another, there is a } \\
\text { general need to modify the basis of competitive advantage that they attempt to } \\
\text { achieve in the marketplace }\end{array}$ \\
\hline
\end{tabular}




\subsubsection{PUBLIC DIPLOMACY AND NATION BRANDING}

The political element is strongly involved in a decision process for country management. Nation branding, as a new branding approach involving political entities, has been discussed with the dimension of public diplomacy. Reflecting on the basic concept of public diplomacy along with nation branding, this section explains why public diplomacy can be pertinent to performance in nation branding.

\section{TRANSFORMATION OF CONCEPT INTO NEW PUBLIC DIPLOMACY}

Public diplomacy, a term coined in the United States in the 1960s for international relations between national governments, focuses on the ways in which a country (or multilateral organization such as the United Nations) communicates with citizens in other societies. Since the concept has been described by the Edward R. Murrow Center in 1965, the practice of public diplomacy has been related to the influence of public attitudes on the formation and execution of foreign policy. According to the US Advisory Commission on Public Diplomacy 1991 Report, public diplomacy for the open exchange of ideas and information is an inherent characteristic of democratic societies. Its global mission is central to foreign policy, and it remains indispensable to national interests, ideals and a leadership role in the world. The planning group for the integration of the USIA into the Department of State (June 20, 1997) describes that public diplomacy seeks to promote the national interest of the United States through understanding, informing and influencing foreign audiences.

The concept of public diplomacy has been redefined as a 'New Public Diplomacy,' which is strongly oriented on people and with people. Leonard (2002) has pointed out that public diplomacy should be about relationship-building rather than being primarily policydriven. Van Ham (2004) has asserted that a key element of public diplomacy is to build personal and institutional relationships and to communicate with foreign audiences by focusing on values, setting the activity apart from classical diplomacy. The Djerejian Report (2003) has emphasized that public diplomacy is the promotion of the national interest by informing, engaging, and influencing people around the world. Wolf and Rosen (2004) have asserted that new public diplomacy relates to the attitudes and behaviors of publics, which are mutually related to the extent of the behaviour and policies of foreign governments. Moreover, Wolf and Rosen (2004) have insisted that the practice of public diplomacy is not confined to the government agencies (i.e. public sector) charged with responsibility for conducting it, suggesting that the talents of the information / communication / publicity sectors and practitioners should be a priority concern for enhancing a nation's public diplomacy. Snow (2004) also has advocated that public diplomacy cannot come primarily from the U.S. government and the primary source for 
America's image campaign must be drawn from the American people. De Vicente (2004) has viewed public diplomacy as a key dimension of nation branding and assured that it should be regarded as a multi-stakeholder initiative, involving associations, private individuals, businesses, etc. To be effective, a strategy must be able to leverage disparate public diplomatic efforts, such as a network of cultural or language institutes, the giving of development aid or participation in peacekeeping operations worldwide (Ibid). Bátora (2005:3) has described how stakeholders that influence foreign publics are described as non-state actors or societal actors, i.e. professional groups; civic activists and NGOs; politicians and political parties; journalists and media groups; business people, enterprises and producers; academics and universities; religious leaders and religious groups and so on.

Several studies have revealed how to conduct public diplomatic transmissions and transactions. Public diplomacy comprises everyday activities (e.g. everyday cultural activities and products such as films, tourism, theatre, and internet discussion) of citizens internationally, as well as inclusive programs (e.g. student exchange programs, hosting seminars, and meetings with foreign business and academic leaders). Leonard, Stead and Smewing (2002) also have prescribed the development of lasting relationships with key individuals through scholarships, exchanges, training, seminars, conferences, and access to media channels. The GAO Report (2003) has stated, "To inform, engage, and influence global audiences, public diplomacy is carried out through a wide range of programs that employ person-to-person contacts, print, broadcast, electronic media, and other means." Wolf and Rosen (2004:22-23) have presented a few approaches worth considering: the tasks of public diplomacy can be achieved by enlisting creative talent and soliciting new ideas from the private sector, through outsourcing major elements of the public diplomacy mission; responsible business, academic, research, and other nongovernmental organizations could be enlisted and motivated through a competitive bidding process; it would be worthwhile to consider various modes of communicating the "big ideas" of public diplomacy through debate and discussion for the conveyance of the message; the media (e.g. radio transmissions, television programming, print and public speeches) can be employed for the added benefit of transferring public diplomacy messages.

According to the USC Center on Public Diplomacy, effective public diplomacy must involve not only shaping the message(s) that a country wishes to present abroad, but also analyzing and understanding the ways that the message is interpreted by diverse societies and developing listening and conversation skills as well as the tools of persuasion. The Foreign Policy Centre in UK has described that the value of 'public diplomacy' as a strategic tool is to communicate and extract a premium for national reputation. In 2005, the British Council has held a seminar to discuss current issues in British Diplomacy, and called for an end to short-term image-centred campaigns like "Cool Britannia" in the 1990s and a new approach to how Britain communicates with audiences abroad. Stakeholders in the seminar put the emphasis on public diplomacy focusing on building long-term trust and 
a closer integration of public diplomacy with actual policy. Leonard, Small and Rose (2005) have examined how a country can forge a new public diplomatic role and proposed a five-part blueprint to achieve the public diplomacy goals (Table 10): namely, to set the priorities that respond to new circumstances; to communicate strategically integrating foreign policy strategy and setting the messages; to build trust partnership with stakeholders; to establish two-way communication; and to channel public diplomacy efforts into non-governmental routes and share public diplomacy goals.

Table 10 New public diplomacy goals

\begin{tabular}{|c|c|c|}
\hline \multirow{2}{*}{$\begin{array}{l}\text { Major } \\
\text { public } \\
\text { diplomacy } \\
\text { goals }\end{array}$} & Medium-term & $\begin{array}{l}\text { How to present nation and its policies in ways that are genuinely convincing } \\
\text { and attractive to international audiences }\end{array}$ \\
\hline & Longer-term & $\begin{array}{l}\text { Trust-building, the creation of a climate of mutual understanding, trust and } \\
\text { respect }\end{array}$ \\
\hline \multirow{5}{*}{$\begin{array}{l}\text { To } \\
\text { achieve } \\
\text { the goals }\end{array}$} & \multicolumn{2}{|c|}{$\begin{array}{l}\text { 1. New priorities } \\
\text {-Channeling resources to focus on allies } \\
\text {-Pooling resources with other countries to achieve common goals } \\
\text {-Public diplomacy activity to promote developmental objectives }\end{array}$} \\
\hline & \multicolumn{2}{|c|}{$\begin{array}{l}\text { 2. Strategic communication } \\
\text {-The integration of public diplomacy at the heart of foreign policy strategy } \\
\text {-Setting strategic messages and planning, ensuring all public diplomacy organizations have } \\
\text { a stake in the messages }\end{array}$} \\
\hline & \multicolumn{2}{|c|}{$\begin{array}{l}\text { 3. Relationship building } \\
\text {-Building trust in partnership, and the need for non-governmental forms of contact }\end{array}$} \\
\hline & \multicolumn{2}{|c|}{$\begin{array}{l}\text { 4. The need for mutuality } \\
\text {-A commitment to communicate in a genuine two-way street, with intellectual awareness } \\
\text { and understanding }\end{array}$} \\
\hline & \multicolumn{2}{|c|}{$\begin{array}{l}\text { 5. Independence and trust } \\
\text {-Channelling public diplomacy efforts into non-governmental routes } \\
\text {-A continuance of the crucial role by organizations (e.g. the British Council) in building } \\
\text { trust because of its non-governmental approach to public diplomacy } \\
\text {-Understanding and sharing public diplomacy goals }\end{array}$} \\
\hline
\end{tabular}

(Source: Adapted from Leonard et al., 2005)

Wolf and Rosen (2004) have claimed that a country's values (e.g. democracy, human rights and individual opportunities) are key indicators that provide soft power in a diplomatic environment. Quelch and Jocz (2005) have insisted that positioning and national image matter greatly in public diplomacy, and suggested positioning a nation-state based on a frank appraisal of perceptions and realities, measuring the progress, working with the private sector, and involving the nation's top leader. Since the ultimate purpose of public diplomacy and its relation to the goals of foreign policy should be to build relationships with stakeholders at multiple levels, in particular, being carried out at the subnational level, Wang (2006) has insisted that the promotion of a nation's policy goals is reinforced when there is a better understanding and appreciation of the country's soft 
power. Fan (2007) argues that soft power is context specific (i.e. a form of soft power is relevant to only one specific country or a specific group in that country). Placed in the context of the uncertainty and contingency aspects, Fan (2007:5) has particularly insisted on the consideration of three perspectives in building soft power as shown in Table 11.

Table 11 Key perspectives in building soft power

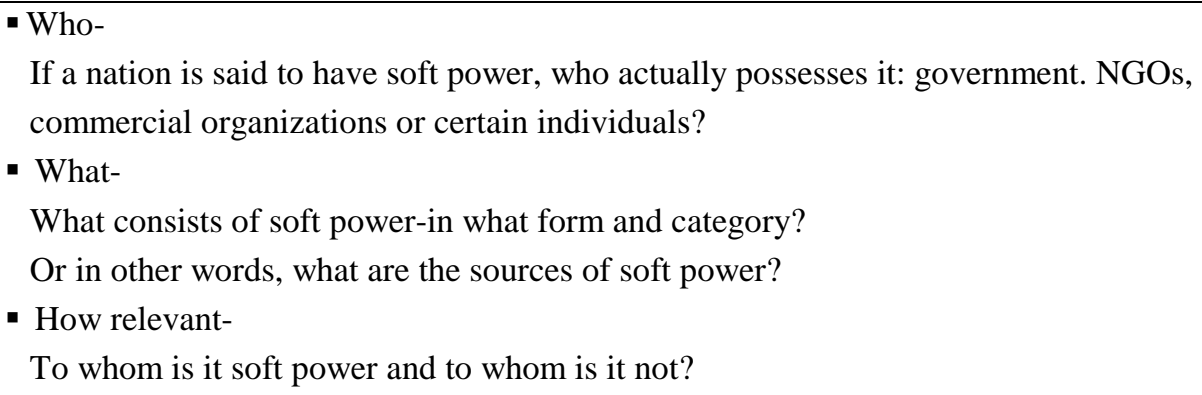

Meanwhile, Noya (2006) has provided a theoretical and empirical review of Nye's dualist theory of power (i.e. hard and soft power), and asserted that citizens have a 'realistic' perception of power and do not perceive a conflict between hard and soft factors. Rather, power is clearly socially based and fed only by certain sectors in society, specifically more educated people and the post-materialist sectors (Noya, 2006). Moreover, Melissen (2006) has debated the point of similarity and difference between nation branding and public diplomacy as follows: both practices are principally aimed at foreign audiences but they also have a vitally important domestic dimension. Meanwhile, the difference is that public diplomacy is fundamentally conducted through dialog, promoting and maintaining relationships [emphasized] in an international environment that is characterized by multiple links between civil societies and the growing influence of nongovernmental actors, but the main features of nation branding are its holistic approach that aims at the projection of identity.

\subsubsection{KEY CONCEPT OF NATION BRANDING}

This research aims to define the role of nation branding and create a strategic management tool on nation branding for the sustainable competitiveness of nations. Particularly in formulating this research objective, we have highlighted the importance of sustainability and brand alignment notions with respect to country management for competitiveness. In this section, we address key concept of nation branding based on the findings in previous sections, in particular, focusing on the role of nation branding and a strategic management approach to nation branding.

To define the role of nation branding, we have observed the existing literature in the nation-branding context, particularly focusing on the academic disciplines of marketing and 
international relations. Within the discipline of marketing, on the one hand, we found that country-of-origin research mainly focused on products at the firm level and on consumers' behaviours (including location decisions of multinational companies) and that it concerned country-of-origin as just one of image variables. This country-of-origin research scope has been limited to defining a nation brand only as a perceptual entity and to promoting a country's image. Branding a nation is, on the other hand, linked to the concept of marketing place development. The concept of place development has insisted that competitive advantage in global markets relies on place and its economic development. Place branding is highlighted as the core concept of place development and marketing. Nation branding, as a unit of place branding, aligns with the more meaningful concept of place branding. Meanwhile, with respect to the discipline of international relations, nation branding refers to as soft power, i.e. a branding approach to political entities. Within this context, public diplomacy based on the branding concept emphasizes its main roles of building a trust relationship with the people in international environments and communicating a nation's interest and message with them. As a result, the concept of nation branding has evolved within the three domains of country-of-origin, place development and public diplomacy, and combines them to create nation brand effects both internally and externally. That is, nation branding is to build a nation's development and economic growth as the internal nation brand effect and to create a positive country-oforigin effect as the external nation brand effect, based on the creation of a trust-based relationship with the people through communication.

The existing literature on these domains of nation branding has emphasized the role of nation branding as an 'umbrella branding'. In the context of country-of-origin and nation branding, Kotler et al. (1999) have argued that sub-brands cannot escape the "trademark" of their nation. Jaffe and Nebenzahl (2006) have asserted that without an umbrella branding (Table 12), uncoordinated or fragmented branding can result, and that success requires combining the stakeholders and their interests into a joint process of branding to achieve the ultimate goal of nation branding. In the context of place development and branding, Lodge (2006:9) has asserted that holistic place branding (encompassing everything that a place wishes to sell) is on its way to becoming recognized as a necessary tool for economic growth and a unified sense of purpose. As Therkelsen and Halkier (2004) have pointed out, an application of umbrella branding for a nation provides advantage in terms of economies of scale - applying the same branding strategy in several areas - and the possibility of synergy when a unified national image is consistently projected to the external world.

Table 12 Requirements of umbrella branding

1. Defining the common functional requirements of diversified stakeholders

2. Finding a common core of values from the functional requirements

3. Building a brand that will communicate the core values to all target audiences

(Source: Jaffe \& Nebenzahl, 2006:144) 
The concept of 'umbrella branding' extends the role of nation branding to nation brand management. Kerr (2006) has argued that more interdisciplinary and holistic approaches to place brand management are gaining interest. Anholt (2007a) has asserted that it is useful to synthesize brand management with public diplomacy and with trade, investment, tourism and export promotion. Dinnie (2008) has insisted that the academic disciplines of national identity and country-of-origin converge to nation branding, and that countries need brand management techniques in order to compete effectively on the world stage.

Based on the existing literature on nation branding, a nation brand refers to as an 'umbrella brand' that encompasses all dimensions of national brands from different functional sectors (i.e. tourism, investment, export, public diplomacy) to place sectors (e.g. regions, cities) (Dooley \& Bowie, 2005). Nation branding is a total concept that needs a 'holistic branding approach' to managing the nation brand, i.e. from a country name through to all the collected activities for all endorsed dimensions of national brands. However, we have observed some limitations and opportunities in defining the role of nation branding. First, even though the existing literature has defined the nation-branding concept as umbrella branding, the research has limited itself to defining nation branding in each domain independently, and this fails to explain the role of nation branding in creating national development and country-of-origin effects both internally and externally. Second, researchers have emphasized the importance of nation brand management. However, they have limited the management role in nation branding to a purely technical notion.

Meanwhile, considering nation branding as the total concept to manage the nation brand, we have found some opportunities to define the role of nation branding with the notions of sustainability and strategic management. First, nation branding should apply an advanced brand theory not only including a simple definition of branding (such as advertising), but also a wide area of organizational strategy (Anholt, 2005b). Second, branding applied to a nation is an intelligent way of achieving a nation's sustainable development, and a nation should develop a brand management system (Pant, 2008; Mihailovich, 2006; Freire, 2005). That is, nation branding should strategically develop a robust nation brand system and then holistically manage that system.

Therefore, this research emphasizes that key concept of nation branding (Fig. 9) has been based on a "tripod", i.e. country-of-origin, place development and public diplomacy. From these notions, nation branding is to combine them and to create a nation brand to achieve nation brand effects. This process needs an umbrella branding and a strategic brand management approach that can sustain a nation-brand system. In particular, reflecting the importance of the nation brand's alignment with country management, we highlight four aspects of nation branding as follows: (1) aligning a nation brand with a national strategy; (2) building a nation brand strategy; (3) building a nation brand identity and image; and (4) managing a nation brand behaviour. 
Fig. 9 Key concept of nation branding

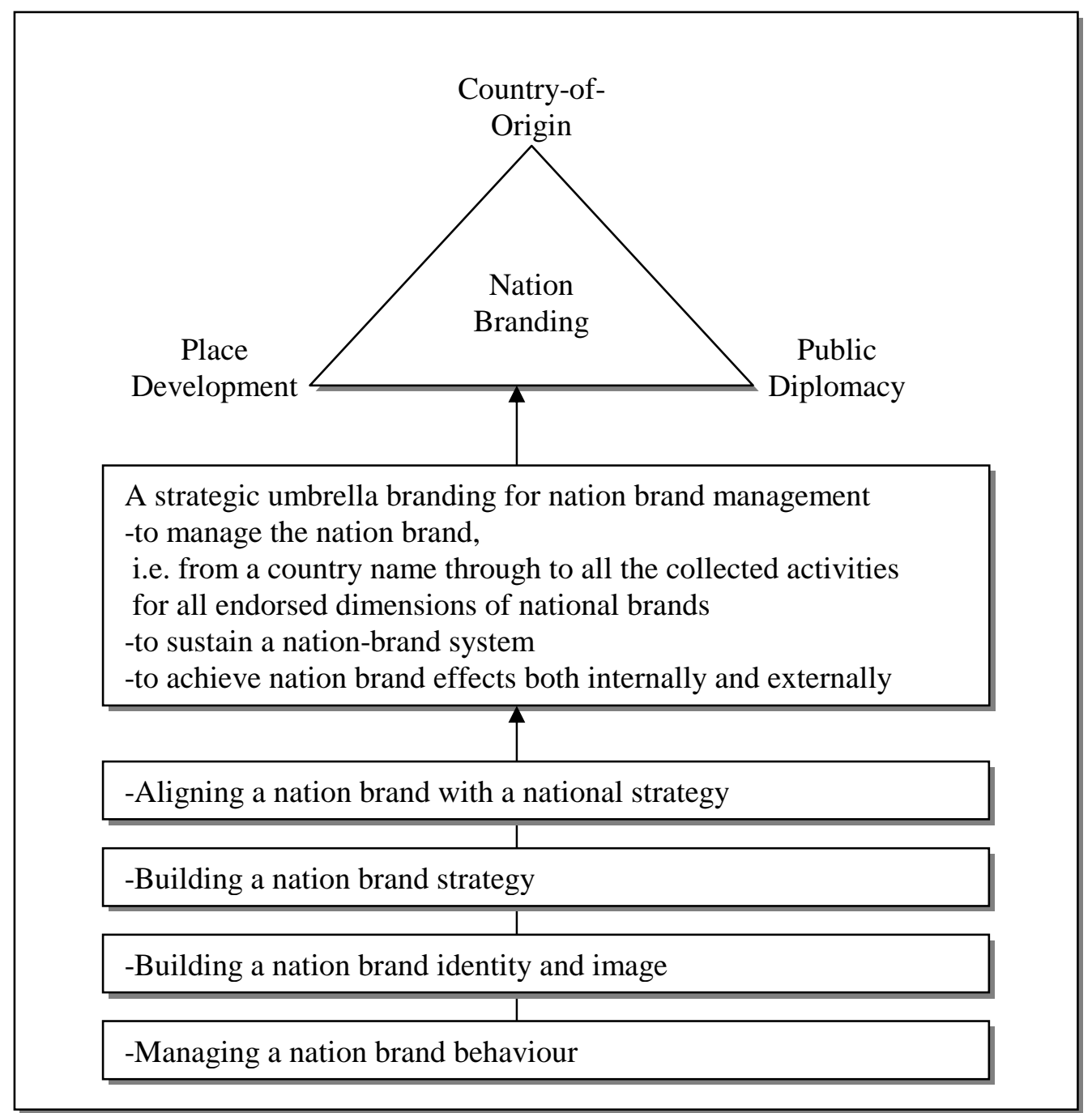

\section{ALIGNING A NATION BRAND WITH A NATIONAL STRATEGY}

As nation branding is a set of practices that aims to align the way the nation and its subjects think of and conduct themselves within the logic of the 'reality of globalization' (Dzenovska, 2005:176), nation brand management is primarily aligned with the role of nation branding. Therefore, it needs to consider that branding a nation must be an amplification of what has been correctly defined as the core values and ideology of a country (Gilmore, 2002:284-85). To endure against competitive environmental changes as well as represent the nation itself, the brand of a country (i.e. the nation brand) must sit at its heart, driving the country's strategy and its direction (Fig. 10), and act as a guide to the strategic decision-making processes of country management (Ibid). 
Fig. 10 A brand-centred management

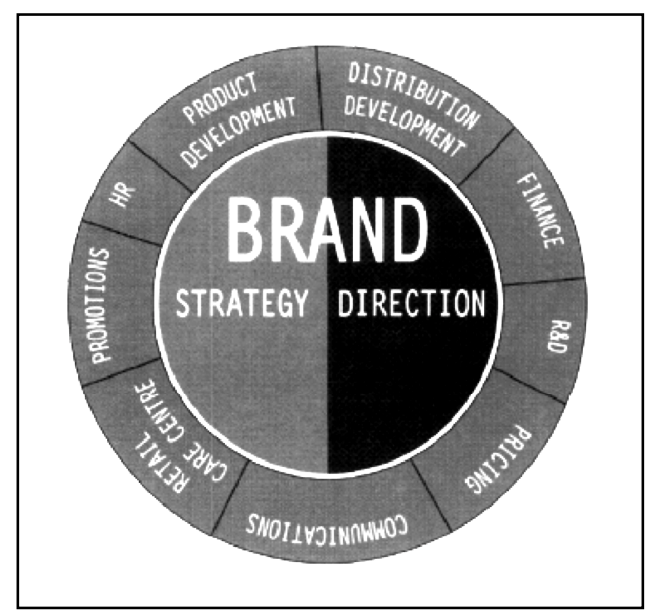

(Source: Gilmore, 2002: 285)

Papadopoulos and Heslop (2002) assert whether branding is appropriate to countries as a strategy or not is based on the theory that a common desire for economic growth can motivate various agents/actors in a place towards a concensus regarding which economic development policies it adopts. Nations continue explicitly (and sometimes implicitly) to shape and reshape their identities, and the people and nation itself continue to demonstrate many traditional characteristics (Olins, 2002). This elucidation validates that people who share some characteristics are entitled to form a national identity as a 'unique entity' in terms of time and space (Georgescu \& Botescu, 2004). People live within the brands and branded system that reflect the way they act, think, and are perceived (Jaworski \& Fosher, 2003). That is, along with the alignment of the country's strategy, the core of a nation brand must capture the spirit of the people of country and their shared purpose (Gilmore, 2002).

\section{BUILDING A NATION BRAND STRATEGY}

To achieve a nation's goals in the economic area, a nation brand strategy is one of the solutions (Florek, 2005). O'Donovan (2004) refers to nation branding as the practice of applying a brand strategy to the economic, social, political and cultural development of a country, and argues that approach results in a highly positive international reputation for the country and enables to achieve successful nation branding. Nation brand strategy has been importantly highlighted in terms of creating and managing a nation brand. It should integrate economic, social, political and cultural disciplines, and should deal with the overall planning of the national strategy. It is possible through clear brand strategy to devote the necessary resources to the branding task (Kyriacou \& Cromwell, 2004). Anholt (2004: 9) insists, moreover, that the real value of nation brand strategy is to provide a government with a strategically robust set of criteria for selecting the actions and behaviours that best suit the country's aims and visions. Nation brand strategy is a means to integrate all messages that a country wishes to communicate to the world, and encompasses 
factors, i.e. subject's activities in building and promoting identities, as a strategic framework for nation branding (Cho, 2004).

An interview was done by Simon Anholt and Wally Olins - known as two gurus in nation branding, which provides the strategic pillars of nation branding (Table 13). Their perspectives related to nation branding show both similarities and differences. Nations are branding themselves for attracting investment and creating economic wealth. In line with a government's initiatives and behaviors, it is important to strike an internal and external balance and a policy-based how-to-do approach. It needs to connect channels of communication (e.g. policy, culture, people, products and tourism) in a joint strategy, to consider a coherent approach to short, medium and long term planning, and to show a leadership from the very top, i.e. the head of government and/or head of state. In leveraging to shape the brand positioning of a country, the role of everybody as well as institutions and politicians, in particular, is emphasized to be brand champions.

Table 13 Strategic pillars of nation branding practices

\begin{tabular}{|c|c|c|}
\hline & S. Anholt & W. Olins \\
\hline $\begin{array}{l}\text { What differentiates } \\
\text { "nation branding" from } \\
\text { commercial branding? }\end{array}$ & $\begin{array}{l}\text {-Nation brand has little in common } \\
\text { with the way that commercial brands } \\
\text { are built by advertising, logos and } \\
\text { slogans }\end{array}$ & $\begin{array}{l}\text {-Nation branding is related to diverse } \\
\text { stakeholders and needs to deal with } \\
\text { both the public sector and the private } \\
\text { sector }\end{array}$ \\
\hline $\begin{array}{l}\text { What are the strategic } \\
\text { pillars of nation } \\
\text { branding? }\end{array}$ & $\begin{array}{l}\text {-Connecting policy, culture, people, } \\
\text { products and tourism in a joint } \\
\text { strategy } \\
\text {-A coherent approach and leadership } \\
\text { for short, medium and long term } \\
\text { planning }\end{array}$ & $\begin{array}{l}\text {-A balance between the internal and } \\
\text { external focus } \\
\text {-An understanding and integration of } \\
\text { the input } \\
\text {-Need a support of the people as } \\
\text { nation brand champions }\end{array}$ \\
\hline $\begin{array}{l}\text { Why is it necessary for } \\
\text { a nation to brand itself? } \\
\text { What are the benefits? }\end{array}$ & $\begin{array}{l}\text {-To make public opinion ensure that } \\
\text { this nation brand is as true as it can } \\
\text { be to the aims of the country. } \\
\text {-To make export, tourism, cultural } \\
\text { relations, investment promotion, and } \\
\text { so on }\end{array}$ & $\begin{array}{l}\text {-To attract foreign investment, } \\
\text { tourism, and export their products in } \\
\text { competitive world } \\
\text {-To create a platform where a nation } \\
\text { attracts a greater share of the world's } \\
\text { wealth }\end{array}$ \\
\hline $\begin{array}{l}\text { What are the roles of } \\
\text { institutions, symbols, } \\
\text { individuals, } \\
\text { companies? }\end{array}$ & $\begin{array}{l}\text {-The companies, tourism, other } \\
\text { people, sport, and culture need to be } \\
\text { promoted to "round out" what is still } \\
\text { a pretty thin brand }\end{array}$ & $\begin{array}{l}\text {-Institutions shape people's } \\
\text { perceptions about national brands. } \\
\text { Public diplomacy and politicians play } \\
\text { a major role in that }\end{array}$ \\
\hline $\begin{array}{l}\text { How can a country } \\
\text { with many symbols } \\
\text { present itself? }\end{array}$ & $\begin{array}{l}\text {-All countries are diverse, unlike } \\
\text { products. Richness is an asset, not } \\
\text { an obstacle. -An advertising issue is a } \\
\text { concern } \\
\text { merely for the tourist board }\end{array}$ & $\begin{array}{l}\text {-You should not have too many } \\
\text { symbols or initiatives because they } \\
\text { confuse the audience. } \\
\text {-Visualize the core idea }\end{array}$ \\
\hline
\end{tabular}

(Source: http://www.designindabamag.com/2006/2nd/brand_the_beloved_country.htm)

Nations explore different strategies for achieving their nation brand goals (Dinnie, 2008: 219). However, there are certain basic strategic principles (Fig. 11). 
Fig. 11 The basic principles of a nation-branding strategy

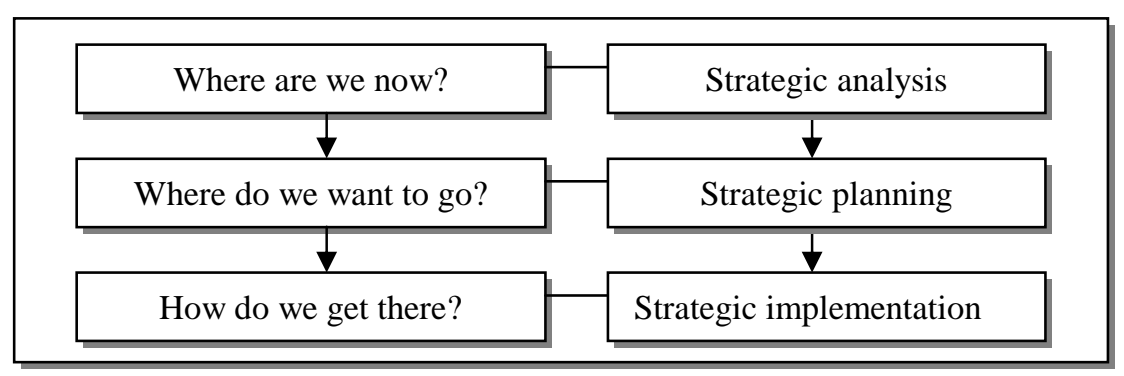

(Source: Dinnie, 2008:220-24)

A brand's positioning defines a brand's point of reference by identifying the attributes which make the brand similar to other places and which make it unique within the competitive set (Hankinson, 2004: 115). Papadopoulos and Heslop (2002) assert that a country is a 'corporation' that produces many products, and that it needs a corporatepositioning strategy based on its core competencies, which derive largely from people, ideas, approaches, and styles of doing business. For example, the perceived competencies of Switzerland (accuracy, trustworthiness and so on) are transferable and actionable in unique ways to the different 'product lines' of that country, such as tourism, banking and the exporting of watches and premium dairy products (Ibid). The issue is not so much one of needing to develop 'a single strategy' but one of developing distinct strategies for each of several outputs that can be meaningfully distinguished from each other and coordinated so that they do not conflict (Papadopoulos \& Heslop, 2002).

\section{BUILDING A NATION BRAND IDENTITY AND IMAGE}

Nation branding is about the ways in which a whole country differentiates, symbolizes and communicates itself to all of its audiences, which relates to building and managing a nation's brand identity and image. It is widely accepted that brand identity is how the brand is intended to be perceived and brand image is the perception of a brand in the minds of people. As Dinnie (2008:42) states, the core concepts of brand identity and brand image are eminently transferable from the context of products, services or corporations to the context of nation branding. In the nation branding context, they are described in various ways. For instance, from a country-of-origin perspective, nation branding is to meet the identitybuilding requirements imposed upon its national brands by the global marketplace and to build a nation's image that derives from the mutual transfer of images of particular companies and products. In terms of place development and branding, identity and image form an entity for branding a nation. To build a brand relationship with foreign audiences, the nation's brand identity and image forms the center of building foreign policy and managing diplomatic efforts. Even though there are diverse views from the different perspectives, building brand identity and image of a nation is a selective process of identifying a nation's values and therefore inextricably linked with managing the nation brand. 
To develop an understanding of a nation brand identity and image, an analysis of the components of brand identity and image is a useful starting point (Dinnie, 2008:42). The notion of a national image (or country image) provides an important aspect of the components of a nation brand identity and image. Jaffe and Nebenzahl (2006) define national image (or country image) is a dynamic phenomenon including smaller or larger localities (such as cities, states, or regions) and by branding should be strategically determined and controlled. Examining the concept of a nation brand image, Dinnie (2008:47) insists that segmentation of target audiences needs to be carried out in order to both monitor and influence the image. Researchers highlight the national image (or country image) and nation brand image in alternative way.

However, there is a common notion that in order to build a national image or nation brand image, a nation's brand identity must be created and developed at the same time (Dinnie, 2008; Rainisto, 2003). Kotler and Gertner (2002:251) refer to the national image (or country image) as the sum of beliefs and impressions people hold about places, and describe that it results from a nation's geography, history, proclamations, art and music, industrial products, famous citizens and other social features. For effective nation branding, the desired national image must reflect reality, and be believable, simple, appealing, distinctive and conscious (Ibid). "Perception is reality" (Jaworski \& Fosher, 2003:100). Building a national image as a brand perception is linked to building a nation brand identity, in particular, based on the real contents (reality) of the country.

The role of brand management is to define and manage a brand identity as a means of achieving competitive advantage (Hankinson, 2004:111). Therefore, effective nation branding relates to building and managing a nation brand identity. Researchers elaborate a nation brand identity with multifaceted aspects of the reality from natural and authentic to technological and competitive (see Table 14).

Based on the genuine perspective of nation branding, Gilmore (2002:283) refers to a nation brand identity as 'communication equities' - the 'ownable' brand communication assets, ranging from historical and political events to particular individuals and physical structures. Martinovic (2002) emphasizes the marketing identity of country as the genuine country features that make up its geopolitical, economic, social and cultural environment. Florek (2005) accounts for the fact that the country products are diverse based on a nation's strength in its brand being the creation of core brand identity (i.e. the set of ideas, values, features, culture, words, images and so forth). Dinnie (2008) asserts that a key task in constructing a nation brand identity is to identify the elements of national identity.

A place's brand image is inevitably linked with the place's national identity that is rooted in both culture and politics (Skinner \& Kubacki, 2007). National identity is the driver developing the nation brand and the democratic process (Wetzel, 2006). Gnoth (2002) argues that the choice of brand attributes helps determine and shape competitiveness as well as the identity, and that the pool of attributes consists of the attraction, essential services, supporting primary and secondary industries, and all export products. To modify 
the basis of competitive advantage, a place brand platform is developed as an integrated form that combines a variety of sourced place factors into the place essence and the place competencies: the essence of the place brand consists of values and manifestations of the place; competencies are based upon capabilities and innovativeness (Zerrillo \& Thomas, 2007).

As a total concept of a nation brand identity, Frasher et al. (2003) refer to a nation brand identity as an umbrella identity encompassing sub-brands applied to four dimensions (tourism, FDI, export, and political influence) of the country. In the context of tourism, brand identity has two components of an authentic place and the natural centre. In the context of FDI, the country is identified as the physical and economic centre, a stable macro economic environment, and the qualities of the people themselves. In a similar vein to FDI, there is an opportunity for the brand to project the idea of the people being excellent providers of industries and of location as a hub for trade. For political influence, brand identity can be articulated as an essential partner in any initiative or event impacting on other places.

Table 14 Nation brand identity and its sources

\begin{tabular}{|c|c|c|}
\hline Reference & Nation brand identity & Sources of nation brand identity \\
\hline $\begin{array}{l}\text { Morgan, Pritchard } \\
\text { \& Piggott } 2002\end{array}$ & The brand values & $\begin{array}{l}\text { Warm, friendly and welcoming openness, natural and } \\
\text { unpretentious, unique heritage }\end{array}$ \\
\hline Gnoth 2002 & Brand attributes & $\begin{array}{l}\text { The attraction, essential services, supporting primary } \\
\text { and secondary industries, and all export products }\end{array}$ \\
\hline Gilmore 2002 & Communication equities & $\begin{array}{l}\text { Historical and political events, particular } \\
\text { individuals, physical structures }\end{array}$ \\
\hline Martinovic 2002 & Marketing identity & $\begin{array}{l}\text { The key features of the economic, social and } \\
\text { cultural activities of its population }\end{array}$ \\
\hline $\begin{array}{l}\text { Papadopoulos } \\
\text { \& Heslop } 2002\end{array}$ & $\begin{array}{l}\text { Outputs which consist of the } \\
\text { products, services and actions }\end{array}$ & Core competencies and product lines \\
\hline $\begin{array}{l}\text { Jaworski \& Fosher } \\
2003\end{array}$ & Essence and core values & $\begin{array}{l}\text { A nation's people, beliefs, history, innovation, skill } \\
\text { and know-how }\end{array}$ \\
\hline Rainisto 2003 & $\begin{array}{l}\text { A unique set of place } \\
\text { attraction }\end{array}$ & $\begin{array}{l}\text { The most unique know-how-expertise and resources } \\
\text { of the place }\end{array}$ \\
\hline Frasher et al., 2003 & An umbrella identity & $\begin{array}{l}\text { An authentic place and the natural centre (Tourism); } \\
\text { the physical and economic centre, a stable macro } \\
\text { economic environment, and the qualities of the } \\
\text { people themselves (FDI); the people being excellent } \\
\text { providers of industries and location as a hub for trade } \\
\text { (Export); an essential partner (political influence) }\end{array}$ \\
\hline Hankinson 2004 & Brand personality & Functional, symbolic and experiential attributes \\
\hline Florek 2005 & Core brand identity & $\begin{array}{l}\text { The set of ideas, values, features, culture, words, } \\
\text { images and so forth which produce in the receiver } \\
\text { defined associations with the country }\end{array}$ \\
\hline $\begin{array}{l}\text { Skinner \& Kubacki } \\
2007 \\
\end{array}$ & National identity & Cultural and political entities \\
\hline $\begin{array}{l}\text { Zerrillo \& Thomas } \\
2007\end{array}$ & Place brand platform & $\begin{array}{l}\text { The essence: values and manifestations; } \\
\text { Competencies: capabilities and innovativeness }\end{array}$ \\
\hline
\end{tabular}


What is the most important notion is that nation branding is to manage a nation brand that is based on the reality of the country. In particular, reality is changing, and this transformation is both internally and externally driven (Szondi, 2007). Therefore, nation brand identity and image should always correspond in a systematic way to maintain continuity of the brand reality, which needs to take a strategic approach (Ibid). The identity is a result of planned activities, and its image is the passive process outcome (Rainisto, 2003). Ultimately, nation branding aims to improve a nation brand identity, image and reputation.

\section{MANAGING A NATION BRAND BEHAVIOR}

Nation branding aims to improve a nation's image and reputation, which can only occur if the nation's actions are well-communicated and well-perceived (Dinnie, 2008). A nation brand is built through the country's actions and behaviours (Anholt, 2006b:179). 'Country behaviour' refers to the work of the country that the communication of brand identity is made through, entailing "national policy, decisions and work undertaken by the leaders of the country and their departments [...] and all the events that occur in a given country that are to do with politics, economics, science, sport or culture" (Florek, 2005: 209-210). To achieve a sustainable competitive advantage in the marketplace, nations need to engage in a degree of consistent behaviour (Anholt, 2005b:117). With respect to anthropological perspectives, moreover, Dzenovska (2005) traces the discourses of branding actors who are actively involved in nation branding or identified as supportive of nation branding efforts. In line with advanced branding theory and the anthropological discipline, nation branding needs to define how branding actors have been involved in country behaviours. If there is indeed nation branding, the first question to be addressed is who is responsible for nation branding (Fan, 2006:8).

The crucial role of the government in nation branding is pointed out in academics and practices. Anholt (2005a) recommends that the government plays the role of a holding company managing a group of related sub-brands. A government can formulate communication strategies aimed at improving the image of its country (Jaffe \& Nebenzahl, 2006: 23-24). Kyriacou and Cromwell (2004) describe that in order to develop internal competitiveness and integrate it into the world community, the responsibility of nation branding derives particularly from the government, focusing on its promotion and support for the sectors, its image, as well as establishing relevant legislation and maintaining the rule of law. In particular, nation branding practices aim to govern on three registers that align the activities of the governing actors (Dzenovska, 2005:181). Firstly, it is necessary to align activities of institutions and individuals perceived to be in a position to govern so that they are animated by a compatible logic. Secondly, nation branding influences potential investors, tourists and consumers in ways that result in a purchase decision. Thirdly, nation branding practices aim to affect the conduct of the individuals who constitute the nation. The technologies of government appropriate to each of the three registers differ (Ibid). The 
government of the country has a responsibility to look after the well-being of its citizens, and nation branding must have the support of a competent government, sound policies and value-producing development projects (Gilmore, 2002:293).

To succeed, nation branding needs not only the responsibility of the government but also involves all levels of stakeholders of a country. Without them, a country cannot successfully make use of its resources and capabilities, and risks losing its development and market position (Endziņa \& Luņeva, 2004; Kotler et al., 2004). Stakeholders are virtually all members of the public, i.e. "any group or individual who can affect or is affected by the achievement of the organization's objectives" (Freeman, 1984:46). The various aspects of stakeholders in nation branding are discussed in some viewpoints. One of them refers to as a nation's own people or target audiences (Gilmore, 2002; Gnoth, 2002; Anholt, 2000). Ursache (2003) underlines, "the audience is split into two major categories: that nation's people and everyone else. It seems that most national branding programs are aimed at foreigners - improving one nation's image in the eyes of the rest of the world - but it is equally important to create programs that aim at that nation's own people, because on a long-term basis, a nation is perceived also through its individuals." Gilmore (2002:286-88) refers to stakeholders as target audiences and classifies them into present and future residents; investors, both at home and from abroad; students; retirees; tourists; media and opinion formers. Moreover, Gilmore (2002) insists that these are not mutually exclusive, i.e. a student of a country could become an investor in the future; the tourist of today could become the export purchaser tomorrow and be mutually supportive when taken together.

In terms of management of the nation brand, Loo and Davies (2006) assure that countries generally take one of two approaches: in the first approach, dedicated organizations are set up either by the government or by the business community to promote the nation and its outputs. In the second approach, the government assumes a leadership role and confirms that a consensus on the common denominators to be promoted can be reached and then inspires the private and public sectors to live up to them. Gnoth (2002:268) advocates that the creation of a strategy for the brand attributes needs to be spearheaded by the industry in conjunction with all stakeholders. Industry groups such as chambers of commerce, local councils, tourist boards and government agencies are partners in the effort to maintain or improve a national image, whose ongoing endeavor is necessary to mold consumer preference for products sold abroad (Jaffe \& Nebenzahl, 2006:137). Industry-government cooperation (Papadopoulos, 2004) has been used as a trade barrier in order to foster demand for domestic goods instead of imports (Ibid). The infinitely wide scope of nation branding activity can only adequately be conducted through an inclusive stakeholder approach in pursuit of goals that will benefit the whole nation (Dinnie, 2008:170). The ultimate success of a place brand strategy relies on how effectively the brand mirrors the reality through effective commitment and relationships with stakeholders (Kerr \& Johnson, 2005; Hankinson, 2004). Fehlmann et al. (2002) distinguish stakeholders 
as internal (i.e. national, community, economy, and population) and external (i.e. individual countries, supranational organizations, and others such as correspondents, news agencies, neighbouring regions) parts. Nation branding, as a process that evolves and expands over time, includes both internal and external stakeholders (Table 15).

Table 15 The categories of stakeholders for nation branding

\begin{tabular}{|c|c|c|}
\hline \multirow{13}{*}{$\begin{array}{l}\text { Internal } \\
\text { Stakeholders }\end{array}$} & \multirow{4}{*}{ International Level } & Embassies and consulates \\
\hline & & Inward investment agencies \\
\hline & & Economic development agencies \\
\hline & & International enterprises with a place-bound link \\
\hline & \multirow{3}{*}{ National level } & National governments \\
\hline & & Political parties \\
\hline & & Export \& inward investment agencies; tourist boards \\
\hline & \multirow{2}{*}{ Community Level } & Local and state government \\
\hline & & Regional economic development agencies \& tourist boards \\
\hline & \multirow{4}{*}{ Sector Level } & Public Sector \\
\hline & & $\begin{array}{l}\text { Mayor and/or city manager; business development department; urban } \\
\text { planning department; tourist bureau; conventions bureau; public } \\
\text { information bureau }\end{array}$ \\
\hline & & $\begin{array}{l}\text { Private Sector } \\
\end{array}$ \\
\hline & & $\begin{array}{l}\text { Individual citizens; leading enterprises; local developers/ agents/ } \\
\text { organizations; hospitality and retail industries; facilitating } \\
\text { organizations; tourist agencies; media (newspaper, radio, TV); } \\
\text { society groups (e.g. professional, religious, academics) }\end{array}$ \\
\hline \multirow{3}{*}{$\begin{array}{c}\text { External } \\
\text { Stakeholders }\end{array}$} & $\begin{array}{l}\text { Individual } \\
\text { Countries }\end{array}$ & $\begin{array}{l}\text { Neighboring countries; the most influential countries; countries or } \\
\text { territories with a similar offering }\end{array}$ \\
\hline & $\begin{array}{l}\text { Supranational } \\
\text { Organizations }\end{array}$ & OECD; FTA; UN; WTO; etc. \\
\hline & Others & $\begin{array}{l}\text { Correspondents for the nation in the international press; news } \\
\text { agencies; neighboring regions }\end{array}$ \\
\hline
\end{tabular}

(Source: Lee et al., 2006)

\subsection{NATION BRANDING \& SUSTAINABLE COMPETITIVENESS}

Countries compete in the competitive global environment to develop markets, technology, skills and investment, and to raise their standard of living (Vietor, 2007:1). Competitiveness is the key notion manifesting the economic success of a country and the only question is how best to achieve it (Krugman, 1996:17). As branding is referred to as the starting point in creating a sustainable future for the organization (Kitchin, 2003:69), nation branding is considered to be the central concept in creating and managing the sustainable competitiveness of nations. This section comprises the relevance of nation branding and international business in terms of globalization and competitiveness. In particular, we focus on understanding the concept of sustainable competitiveness as key performance outcome in nation branding. 


\subsubsection{NATION BRANDING AND GLOBALIZATION}

Globalization is a domain that is shared with fields such as international political economy, economic geography, business and society (or social issues in management), and business ethics (Peng, 2004; Freeman, 1997). At the same time, it has been interpreted as the concept of both challenging the competitive pressure and expanding market opportunities on a global basis (Knight \& Cavusgil, 2004; Kotabe \& Helsen, 2000; Porter, 1998; Barney, 1991). Globalization promotes locational advantage by removing artificial barriers to trade and investment, which provides both the opportunity to boost national competitiveness and a threat to increasing or even maintaining it (Porter, 1998).

Recently some celebrated scholars in international business management have insisted on globalization's multiple dimensions and their manageability. Buckley and Ghauri (2004) argued that globalization implies location near the customer and that the differential pace of globalization across markets presents a number of challenges to policy makers in local, national and regional governments. Gill (2002) advocated that globalization, as a multidimensional facet involving ideas, images, symbols, music, fashion, and a variety of tastes and representations of identity and community, is the part of a broad process of restructuring the state, political and civil society, political economy and culture. Kaul et al. (2003) asserted that globalization can be manageable, and that if globalization is to serve as a means of improving people's lives, concerted cross-border public policy action, networked cooperation as well as the free flow of private economic activity must be necessary.

In the nation branding context, there are several conditions that make a branding approach to competitiveness not just desirable but essential (Table 16).

Table 16 Conditions driving a nation branding approach

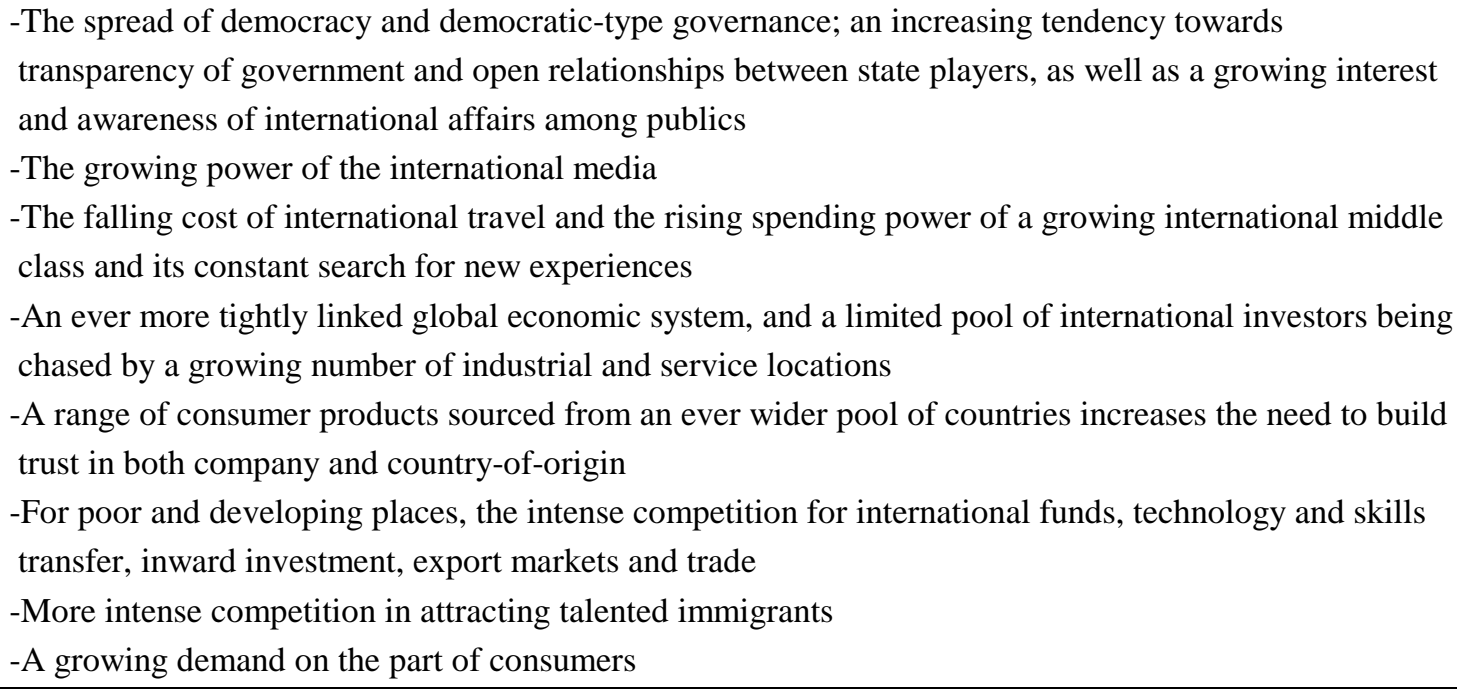

(Source: Adapted from Anholt, 2007a:19-20) 
The common driver of all such changes is globalization, and only those global players with the ability to serve a wide and diverse global marketplace and with a clear, credible, appealing, distinctive and thoroughly planned vision, identity and strategy can compete successfully (Anholt, 2007a:21).

\subsubsection{KEY CONCEPT OF SUSTAINABLE COMPETITIVENESS}

\section{COMPETITIVENESS}

There are no agreed definitions of competitiveness of nations (Table 17), and the term seems to mean different things to different people (Boltho, 1996:1).

Table 17 Definitions of the competitiveness of nations

\begin{tabular}{|c|c|}
\hline Definitions & Sources \\
\hline -Country's ability to generate the resources required to meet its national needs & HMSO, 1985 \\
\hline $\begin{array}{l}\text {-Country's ability to create, produce and distribute service products in international } \\
\text { trade while earning rising returns on its resources }\end{array}$ & $\begin{array}{c}\text { Scott \& } \\
\text { Lodge, } 1985\end{array}$ \\
\hline $\begin{array}{l}\text {-Competitiveness is seen as the ability to perform well; it is the generation and } \\
\text { maintenance of competitive advantages; and it is the process of managing decisions } \\
\text { and processes in the "right" way } \\
\text {-Competitiveness cannot be considered as a static concept, but rather as an ongoing } \\
\text { process }\end{array}$ & $\begin{array}{l}\text { Buckley, Pass } \\
\text { \& Prescott, } \\
1988\end{array}$ \\
\hline $\begin{array}{l}\text {-Competitiveness is the degree to which a nation can, under free and fair market } \\
\text { conditions, produce goods and services which meet the test of international markets, } \\
\text { while simultaneously maintaining and expanding the real incomes of its people over } \\
\text { the longer term }\end{array}$ & OECD, 1992 \\
\hline $\begin{array}{l}\text {-Competitiveness is the ability of a country to achieve sustained high rates of growth in } \\
\text { GDP per capita }\end{array}$ & WEF, 1996 \\
\hline $\begin{array}{l}\text {-A nation which fails to match other nations in productivity or technology will face } \\
\text { the same kind of crisis as a company that cannot match the costs or products of its } \\
\text { rivals }\end{array}$ & $\begin{array}{l}\text { Krugman, } \\
1996\end{array}$ \\
\hline $\begin{array}{l}\text {-Competitiveness in the short run has been equated with the level of the real exchange } \\
\text { rate, ensured internal and (broadly defined) external balance (i.e. desirable level of the } \\
\text { current account) } \\
\text {-Turning to the longer-run aim of rising living standards, a possible definition of } \\
\text { international competitiveness could be the highest possible growth of productivity that } \\
\text { was compatible with external equilibrium }\end{array}$ & Boltho, 1996 \\
\hline $\begin{array}{l}\text {-The "wholeness" is an important characteristic of competitiveness } \\
\text {-Competitiveness analyses how nations and enterprises manage the totality of their } \\
\text { competencies to achieve prosperity or profit } \\
\text {-Competitiveness is the ability of a nation to create and maintain an environment that } \\
\text { sustains more value creation for its enterprises and more prosperity for its people; the } \\
\text { ability of a country to create added-value and thus increase national wealth by } \\
\text { managing assets and processes, attractiveness and aggressiveness, globality and } \\
\text { proximity, and by integrating these relationships into an economic and social model }\end{array}$ & IMD, 2005 \\
\hline
\end{tabular}


The idea that the economic success of a country depends on its international competitiveness took hold among business, political, and intellectual leaders in the late 1970s; the World Economic Forum, which hosts the famous Davos conferences, began to publish its annual World Competitiveness Report in 1980, and the rankings in that report soon became a major criterion by which national performance was judged; by the 1990s, the concept of competitiveness was no longer even controversial among influential people (Krugman, 1996:17).

Competitiveness has given meaning to a country's ability to produce competitive resources based on national needs or international trade and to maintain competitive advantages. In particular, Buckley, Pass and Prescott (1988:177) insisted that competitiveness cannot be considered as a static concept, but rather as an ongoing process and thereby it is a critical aspect of research into the process of competitiveness. Competitiveness embodies a holistic approach to a country's ability to sustain national economic and social development level for its people. To achieve those development goals, it is referred to as a nation's ability to produce goods and services that meet global market needs, to create and manage value-added assets, processes, attractiveness and globalization. In the $21^{\text {st }}$ century, competitiveness comprehends "wholeness" and "totality" that shape the ability of a nation to create and maintain an environment that sustains more value creation for its enterprises and more prosperity for its people.

\section{COMPETITIVE ADVANTAGE}

It is necessary to explain the dynamics of competitiveness, and single measures of competitiveness do not capture all the elements of the concept (Buckley et al., 1988). Competitive advantage, Day and Wensley (1988:1) insisted, is sustained through the integrated framework (Fig. 12) underlying the sequential determinism of the source of advantage, positional advantage and performance outcomes.

Fig. 12 The elements of competitive advantage

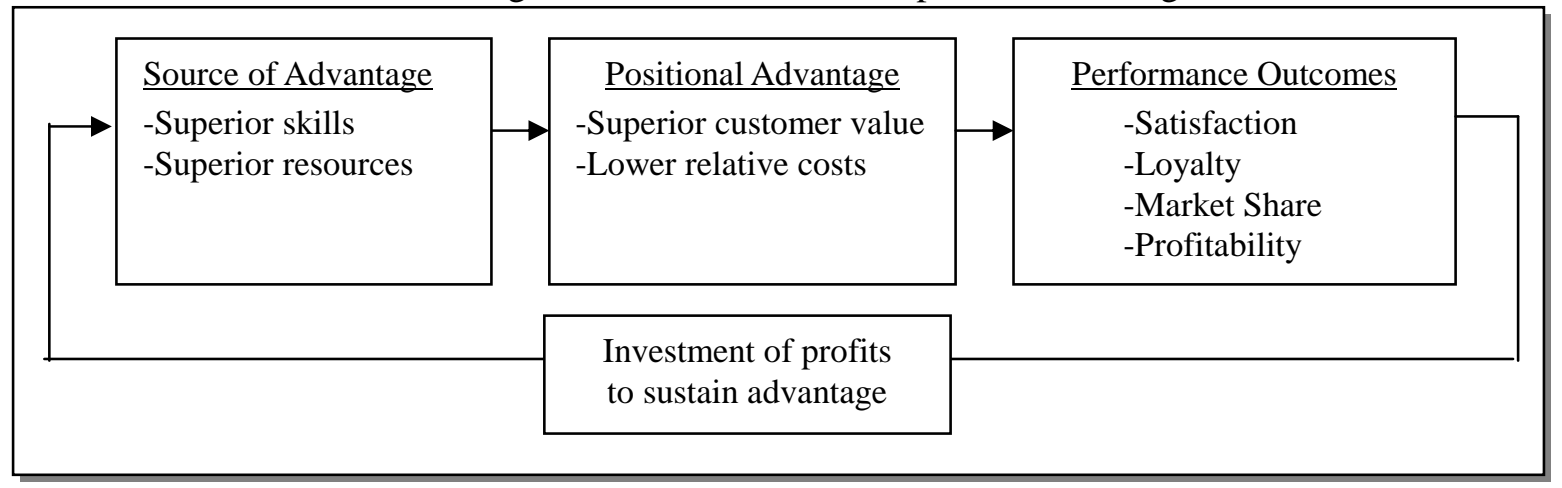

(Source: Day \& Wensley, 1988:3) 


\section{- Source of advantage}

Nations are endowed with differing stocks of factors (Table 18). Factors are grouped into a number of broad categories such as infrastructure, human, physical, knowledge and capital resources, and all of them play a role as the source of the competitive advantage (Porter, 1998:74-75).

Table 18 A category of factor endowment

\begin{tabular}{|c|l|}
\hline Factors & \multicolumn{1}{c|}{ Contents } \\
\hline Human resources & $\begin{array}{l}\text { The quantity, skills, and cost of personnel (including management), taking into } \\
\text { account working hours and work ethic. They can be divided into a myriad of } \\
\text { categories, such as toolmakers, electrical engineers with PhDs, and so on. }\end{array}$ \\
\hline $\begin{array}{c}\text { Physical } \\
\text { resources }\end{array}$ & $\begin{array}{l}\text { The abundance, quality, accessibility, and cost of the nation's land, water, mineral, or } \\
\text { timber deposits, hydroelectric power sources, fishing grounds, climate conditions, } \\
\text { and geographic location, size, time zone and position. }\end{array}$ \\
\hline $\begin{array}{c}\text { Knowledge } \\
\text { resources }\end{array}$ & $\begin{array}{l}\text { The nation's stock of scientific, technical and market knowledge bearing on goods } \\
\text { and services. They reside in universities, government research institutes, business and } \\
\text { scientific literature, market research reports and trade associations. }\end{array}$ \\
\hline Capital resources & The amount and cost of capital available to finance industry. \\
\hline Infrastructure & $\begin{array}{l}\text { The type, quality, and user cost of infrastructure available that affects competition, } \\
\text { including the transportation system, the communication system, funds transfer, health } \\
\text { care, and so on. Housing stock and cultural institutions affect the quality of life and } \\
\text { the attractiveness of a nation as a place to live and work. }\end{array}$ \\
\hline
\end{tabular}

(Source: Adapted from Porter, 1998:74-75)

A hierarchy of sources of advantage structures factors contributing to sustainability (Porter, 1998:74-75). Lower-order advantages (such as low labor costs or cheap raw materials) are relatively easy to imitate, but higher-order advantage is more durable and characterized by more advanced skills and capabilities. Sources of higher-order advantages are not only sustainable but are associated with higher levels of productivity (Ibid). As sources of advantage, superior skills are the distinctive capabilities of personnel that set them apart from the personnel of competitors, and superior resources are more tangible requirements for advantage that enable enterprises to exercise their capabilities, which are the key success factors that must be managed obsessively to ensure long-run competitive effectiveness (Day \& Wensley, 1988:1). Aaker (1989) claimed that assets and skills are the basis of sustainable competitive advantage. Hall (1992) defined intangible assets whose essence is an idea or knowledge, and insisted that they drive capability differentials, which in turn drive sustainable competitive advantage. Sophisticated industries (and segments of industries) involving complex technology and highly skilled human resources offer the potential for high levels of productivity as well as sustained productivity growth (Porter, 1998:10). Human capital and clusters of industries are emerging as the most vital resource that places possess or can develop in place competition (Kotler et al., 1993:322-26). 


\section{- Positional advantage}

Nations are positioning themselves strategically on their abilities to assume an advantage in attracting human and physical capital both regionally and globally. Positional advantage in markets is secured by value-creation activities, which is gained only with considering a market segment characterized by distinct benefits that are perceived and valued by both competitors and customers (Day \& Wensley, 1988:1). Based on the research regarding external environments, some studies deal with market conditions such as market evolution (Teece et al., 1997; Dickson, 1996; Senge, 1993), competition and customer demand (Kessler \& Chakrabarti, 1996; Day \& Nedungadi, 1994). Research has defined market in some perspectives. Day (1990) referred to it, for instance, as a core market including products that offer similar or related functions to groups of customers with distinct needs and as an extended market encompassing all competitive possibilities for satisfying customer needs. Buckley and Ghauri (2004) categorized markets into three levels, i.e. financial markets, markets in goods and services and labour markets.

Meanwhile, Hooley et al. (1988) insisted that there is a typology of strategic market environments in competitive advantage, which are characterized in terms of key environmental factors (Table 19) in competitive positioning. The only significant difference across environment types in competitive advantage relates to product performance and high quality. High price positioning occurs in mature and diverse markets (Ibid.)

Table 19 Market environmental factors

\begin{tabular}{|c|c|}
\hline Market maturity & $\begin{array}{l}\text { (i) A new emerging or a declining market } \\
\text { (ii) An established, growing market } \\
\text { (iii) A mature and stable market }\end{array}$ \\
\hline $\begin{array}{l}\text { Diversity of customer } \\
\text { wants and needs }\end{array}$ & $\begin{array}{l}\text { (i) Many customers each wanting different products or services } \\
\text { (ii) Distinct market segments each wanting different products and services } \\
\text { (iii) All customers want essentially the same products and services }\end{array}$ \\
\hline $\begin{array}{l}\text { Changing customer } \\
\text { requirements }\end{array}$ & $\begin{array}{l}\text { (i) Customer requirements are changing rapidly } \\
\text { (ii) Customer requirements are changing slowly } \\
\text { (iii) Customer requirements are not changing }\end{array}$ \\
\hline Technological change & $\begin{array}{l}\text { (i) Technological change is rapid } \\
\text { (ii) Technological change is slow } \\
\text { (iii) There is no change in technology }\end{array}$ \\
\hline Degree of competition & $\begin{array}{l}\text { (i) Competition is intense } \\
\text { (ii) Competitive rivalry is weak } \\
\text { (iii) There is no effective competition }\end{array}$ \\
\hline Competitive change & $\begin{array}{l}\text { (i) Competition is established and entrenched } \\
\text { (ii) Competition is established but changing }\end{array}$ \\
\hline Barriers to entry & $\begin{array}{l}\text { (i) Competitors can enter but at a cost } \\
\text { (ii) There are substantial barriers to entry }\end{array}$ \\
\hline Barriers to exit & $\begin{array}{l}\text { (i) Competitors can exit but at a cost } \\
\text { (ii) There are substantial barriers to exit }\end{array}$ \\
\hline
\end{tabular}

(Source: Adapted from Hooley et al., 1988:134) 


\section{- Performance outcome measures}

The outcome of the competitive process, i.e. performance outcome (Table 20), provides a historical perspective and insights into the sustainability of such performance (Buckley et al., 1988). In terms of outcome measures, relative market share with a profit performance criterion represents the best approach (Ibid).

Table 20 Performance outcome by level of analysis

\begin{tabular}{|l|l|}
\hline Export market share & -The percentage share of exports relative to a matched comparator \\
\hline $\begin{array}{l}\text { Percentage share of World } \\
\text { manufacturing output }\end{array}$ & $\begin{array}{l}\text {-Market share measured through the national share of world } \\
\text { manufacturing. }\end{array}$ \\
\hline Balance of trade & -Balance of trade between countries. \\
\hline Export Growth & -Export sales growth \\
\hline Profitability & -Rarely referred to in the literature as a proxy for competitiveness \\
\hline
\end{tabular}

(Source: Buckley et al., 1988)

According to Hughes (1993), two broad approaches to analyzing competitiveness can be distinguished. The first is that competitiveness is a question of relative efficiency, which can be measured by looking at the relative performance levels of productivity and productivity growth. The second measure is that competitiveness is reflected in relative international trade performance. The only meaningful concept of competitiveness at the national level is national productivity (Porter, 1998). Hirst (1997) argued that globalization means a continuing process of the growth of international trade and investment. IettoGillies (2005) referred to international trade and international investment (in particular, FDI) as the outputs of macroeconomic performance.

Trade in goods and services has been engaged as the engine of economic growth along with FDI. Nations have represented various patterns in trade and FDI growth. In particular, exports have indicated the competitiveness of a nation's industries, which has explained a nation's performance in global markets. Exports are the amount and value of goods and services produced in one place that are sold and shipped to another place and, in many countries, they are the foundation for the country's power and prosperity (Kotler et al., 1993:261). Export competitiveness has many facets, the most obvious implying higher exports. It also means diversifying the export basket, sustaining higher rates of export growth over time, upgrading the technological and skill content of export activity, and expanding the base of domestic firms able to compete globally; thus, competitiveness is sustained and it is generally accompanied by rising incomes (UNCTAD, 2002:117). FDI (Foreign Direct Investment) refers to the overseas investment of transnational corporations (TNCs) and is one of the main figures indicating location competitiveness based on stocks and flows of FDI activities.

The world economy changed significantly in the 1980s. FDI outflows since 1983 have increased unprecedently by 29 per cent a year, which has been three times faster than that of the growth of world exports. The gap between the growth rate of exports and that of FDI 
outflows since 1985 widened dramatically (Fig. 13), which implies something about the competitiveness of nations given the links between FDI and trade.

Fig. 13 Index of current value of exports and FDI outflows (1975-1989)

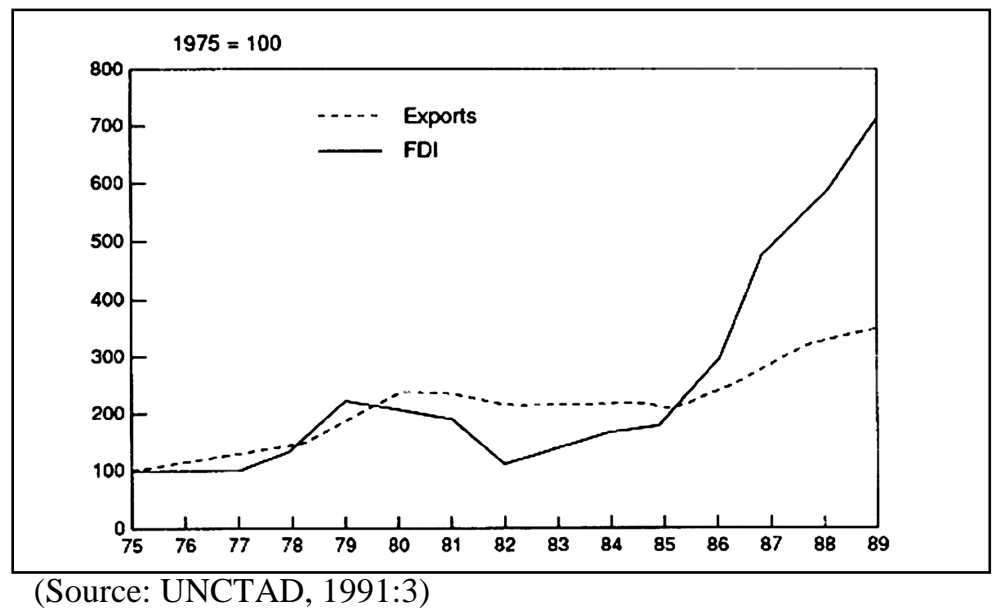

Gersbach (2002) found a strong relationship between globalization and productivity differences based on the most efficient producers (i.e. TNCs), and concluded that TNCs' influence spreads beyond a single region such as Europe or North America. In the context of production activity, some interesting figures are relevant to a nation's competitiveness in global markets. TNCs (i.e. transnational corporations) ${ }^{2}$ are the major players that control the bulk of production in global markets. They are not only producers for international trade but also consumers (i.e. investors) who determine foreign investments. The world economy has changed to favour these major players that control the production in global markets and decide to select locations for making products.

TNCs are significant players in world trade markets and increasingly shape trade patterns, accounting for about two-thirds of world trade. About one-third of total trade (or half of the TNC trade) is intra-firm (UNCTAD, 2001). Pursuing their optimal locations for the highest productivity, TNCs are considered as one of the main target markets for nation branding. Therefore, the number of them in a particular nation represents a nation's competitiveness in global markets. As shown by the World Investment Report 2006 (UNCTAD, 2006), the number of TNCs worldwide has risen to about 77,000, controlling at least 770,000 foreign affiliates. As shown in Table 21, their distributions are characterized in several ways: in terms of parent corporations, they are mainly based in developed nations (i.e. about 70 per cent of total) and about 50 per cent of them are located in Europe, in particular in the European Union. Their foreign affiliates are located in developing nations. East Asia is the main region with the highest number of TNC foreign affiliates.

\footnotetext{
2 Transnational corporations are incorporated or unincorporated enterprises comprising parent enterprises and their foreign affiliates (UNCTAD, World Investment Reports).
} 
Table 21 TNCs distribution by country and economy

\begin{tabular}{|c|c|c|c|}
\hline \multirow{3}{*}{ Country Level } & Regional Level & $\begin{array}{c}\text { Parent corporations } \\
\text { based in economy } \\
\text { (number) }\end{array}$ & $\begin{array}{c}\text { Foreign affiliates } \\
\text { located in economy } \\
\text { (number) }\end{array}$ \\
\hline \hline \multirow{3}{*}{$\begin{array}{c}\text { Developed } \\
\text { economies }\end{array}$} & $\begin{array}{c}\text { Europe } \\
\text { (European Union) }\end{array}$ & $\begin{array}{c}44922 \\
(39018)\end{array}$ & $\begin{array}{c}218651 \\
(208026)\end{array}$ \\
\cline { 2 - 4 } & North America & 3857 & 28332 \\
\cline { 2 - 4 } & Japan & 5658 & 4761 \\
\hline \hline \multirow{2}{*}{$\begin{array}{c}\text { Developing } \\
\text { economies }\end{array}$} & Africa & 630 & 36448 \\
\cline { 2 - 4 } & Latin America \& the Caribbean & 16602 & 364194 \\
\cline { 2 - 4 } & Asia \& Oceania (East Asia) & $312906)$ \\
\hline \hline $\begin{array}{c}\text { Other South-East } \\
\text { Europe and the CIS }\end{array}$ & South-East Europe & $12489)$ & 99202 \\
\cline { 2 - 4 } & CIS & 77175 & 10661 \\
\hline World Total & - & 361 & 773019 \\
\hline
\end{tabular}

(Source: Adapted from UNCTAD, 2006:270)

\section{SUSTAINABLE DEVELOPMENT}

Sustainable development is first developed in the 1980s to stress the need for the simultaneous achievement of development and environment goals, however the origins of the concept can be traced back to the increased concern shown for the environment in the 1960s and 1970s (Strong \& Hemphill, 2006). There are many different paths to sustain development, and there is no single, fixed definition of "sustainable development." The goals of development vary, and there are many ways of reaching such goals (Sachs, 1992). Development is increasingly seen as an open-ended process and, indeed, is defined very loosely as a "broadening of people's choice" (UNDP, 1998). However, in spite of these differences, one thing is clear: development is about much more than economic growth and economic development (UNCTAD, 1999: 150). As a comprehensive view of development, the United Nations Charter (1944) mentioned development in the context of economic and social progress and higher standards of living, as well as cultural, educational and health matters. The Programme of Action of the 1995 World Summit for Social Development, for example, embraces a concept of development that includes both developed and developing countries, and deals with eradicating absolute poverty, expanding employment, and increasing social integration (UNRISD, 1995).

In dealing with the concept of development, World Investment Reports of UNCTAD adopt the United Nations' definition of "sustainable human development" that encompasses economic, social, political, environmental and other dimensions. Sustainable development, as the primary challenge for the 21 st century, is a process of "achieving human development [...] in an inclusive, connected, equitable, prudent, and secure manner" (Gladwin et al., 1995) and "improving the quality of human life [...]" (Bond, 2005:39). Encompassing both the challenge and the solution to the global issues, the term "sustainable human development" (Table 22) refers to the global-scale drivers of sustainability. Recently, the Economist Intelligence Unit (2004) presented a range of 
categories relating to the business environment and quality-of-life factors such as socioeconomic well-being for assessing the comparative attractiveness of countries.

Table 22 Sustainable human development indicators

\begin{tabular}{|c|l|l|}
\hline Reference & Index & \multicolumn{1}{c|}{ Indicators } \\
& & -Adult literacy rate (\% aged 15 and older) \\
Human & & -Combined gross enrolment ratio for primary, secondary and \\
tertiary education (\%) & -Education index \\
Development & Human & -GDP index; GDP per capita (PPP US\$); GDP per capita \\
Reports, & Development Index & (PPP US\$) rank minus HDI rank \\
UNDP 2005 & & -Human development index value \\
& & -Life expectancy at birth, annual estimates (years) \\
& & -Life expectancy index \\
\hline Economist & Socio-economic & -Material wellbeing; Job security \\
Intelligence Unit, & Well-being & -Familiy relation; Social and community activites \\
2004 & Conditions & -Health; Gender equality \\
& -Political freedom \& security \\
\hline
\end{tabular}

\section{NATION BRAND EQUITY}

The concept of the brand as a value enhancer has led to the development of the concept of brand equity (Hankinson, 2004:111). Brand equity as a consequence in branding is output rather than input (Hankinson, 2004; Keller, 1998). Nation brand equity (NBE) refers to the tangible and intangible, internal and external assets (or liabilities) of the nation (Dinnie, 2008:67). Nation brand value (NBV) is the total sum of nation brand equity that is created by people, firms, government and products within a country (Cho, 2004).

National image and reputation are essential parts of the competitiveness and brand equity of a nation (Loo \& Davies, 2006; Jaffe \& Nebenzahl; 2006; Gertner, 2004; Van Ham, 2004). Based on stakeholders' attitudes and behaviours in the market, reputation ultimately represents the output of nation branding by embracing those stakeholders' perceptions that are relevant to the nation image (Martensen \& Grønholdt, 2005; MacMillan et al., 2005; Fombrun, 1996). Due to the reputation of the countries as top world manufacturers and exporters, products bearing 'made in Germany', 'made in Switzerland' or 'made in Japan' labels are commonly regarded as high quality (Kotler \& Gertner, 2002:250)

The objective of the process and method of measuring its degree of success in place branding is the increase in brand equity which is the extra benefit enjoyed by the consumer (Kavaratzis \& Ashworth, 2005). When considering a multidimensional view of nation-asbrand, the central organizing concept is 'country equity' or the value that may be embedded in perceptions by various target markets about the country (Papadopoulos \& Heslop, 2002:295). It is due to the growing awareness of the need to market places to more mobile markets in a more competitive environment that the application of the principles of brand 
management to places is receiving greater attention (Kerr, 2006:278). One outcome of the new environment has been the growing number of countries that undertake proactive branding programmes to attract foreign investors and to promote export efforts (Papadopoulos, 2004; Papadopoulos \& Heslop, 2002). One of successful results through place development and branding is represented by place growth (Fig. 14).

Fig. 14 Place growth dynamics

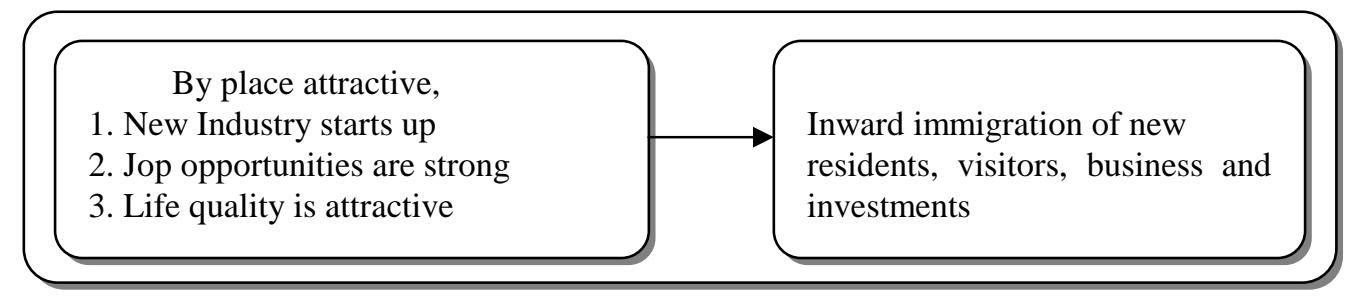

(Source: Adapted from Kotler et al., 1999)

Nation brand equity and value have been measured by combining the customer perspective with the financial perspective based on national competitiveness (Table 23). To measure nation brand value, since 2003 Cho and IPS (the Institute for Industrial Policy Studies) have measured the Country Brand Value of 37 countries as judged by businessmen and consumers in 65 countries. The Country Brand Value Index has adopted brand valuation through multiplying nation brand revenue and the relevant brand power index. Nation brand revenue, a proxy for each country's total sales, is calculated on the basis of three-year tourism income and merchandise and service export volume. The Country Brand Power index is calculated through multiplying the nation brand strategy by branding actors and a combination of national competitiveness and psychological friendliness. Sinclair and the School of Economic and Business Science (University of the Witwatersrand) have developed the Wits technique, aming to measure the brand value of South Africa. This approach recognises that brands are long-life assets and that they will help to generate earnings for many years into the future. The method uses discounted cash flow (DCF) and four core inputs: financial, dilution, category expected life and brand knowledge structure. In particular, for the financial measure, the Wits valuation includes the earnings from export sales, foreign investment and tourism as the earnings that are most sensitive to brand image, the nation brand's competitive ranking and the stability of its region. Since 2005, Anholt and GMI have measured nation brand values of between 10 and 35 nations by 2007. The six key measures of national competence included are: exports, governance, investment and immigration, culture and heritage, people, and tourism. In conjunction with Anholt Nation Brands Index, since 2005 Brand Finance has carried out financial valuations of the nation brands featured in the Nation Brands Index, using an adapted version of the 'royalty relief' method, a valuation technique widely used in commercial brand valuations. 
Table 23 Nation brand valuation

\begin{tabular}{|c|l|l|}
\hline Reference & \multicolumn{1}{|c|}{ Brand Valuation-measures } & Methodology \\
\hline $\begin{array}{c}\text { Cho and IPS } \\
\text { (Source: Korea Brand } \\
\text { Conference, 2003-2007) }\end{array}$ & $\begin{array}{l}\text {-Country Brand Valuation } \\
\text { :National competitiveness index, psychological } \\
\text { friendliness, financial earnings, nation brand } \\
\text { strategy by branding actors }\end{array}$ & $\begin{array}{l}\text { Survey in 65 } \\
\text { countries among a } \\
\text { sample of business } \\
\text { people and citizens }\end{array}$ \\
\hline $\begin{array}{c}\text { Anholt and GMI } \\
\text { (Source: Anholt Nation Brands } \\
\text { Index, 2005-2007) }\end{array}$ & $\begin{array}{l}\text {-The Anholt Nation Brands Index } \\
\text { :Perceptions of the cultural, political, } \\
\text { commercial and human assets, investment } \\
\text { potential and tourist appeal, Royalty relief method }\end{array}$ & $\begin{array}{l}\text { Survey in 35 nations } \\
\text { among a sample of } \\
\text { consumers }\end{array}$ \\
\hline $\begin{array}{c}\text { Sinclair and the School of } \\
\text { Economic and Business Science } \\
\text { (Source: Sinclair, 2004) }\end{array}$ & $\begin{array}{l}\text {-Wits technique } \\
\text { :Financial earnings, dilution,category expected } \\
\text { life and brand knowledge structure }\end{array}$ & $\begin{array}{l}\text { Survey in South } \\
\text { Africa among a } \\
\text { sample of business } \\
\text { people }\end{array}$ \\
\hline
\end{tabular}

The aim of nation branding is to achieve sustainability of the competitiveness of nations. To achieve the sustenance of competitiveness, nation branding needs a substantial and holistic approach to creating competitive advantage and to sustaining a nation's development growth. However, as Pant (2005:273) argued, it is important to transform the 'quality of context' into competitive advantage in international business. Moreover, to sustain the competitiveness of nations, the notion of competitiveness needs to emphasize the notion of nation brand equity. By nation branding, countries are able to create national systems and positions as the reliable and eligible members of the international community (Szondi, 2007). Nation brand value, as the sustainable competitiveness, impacts on a nation's economic, social and political effects (Fig. 15).

Fig. 15 The impacts of nation brand value

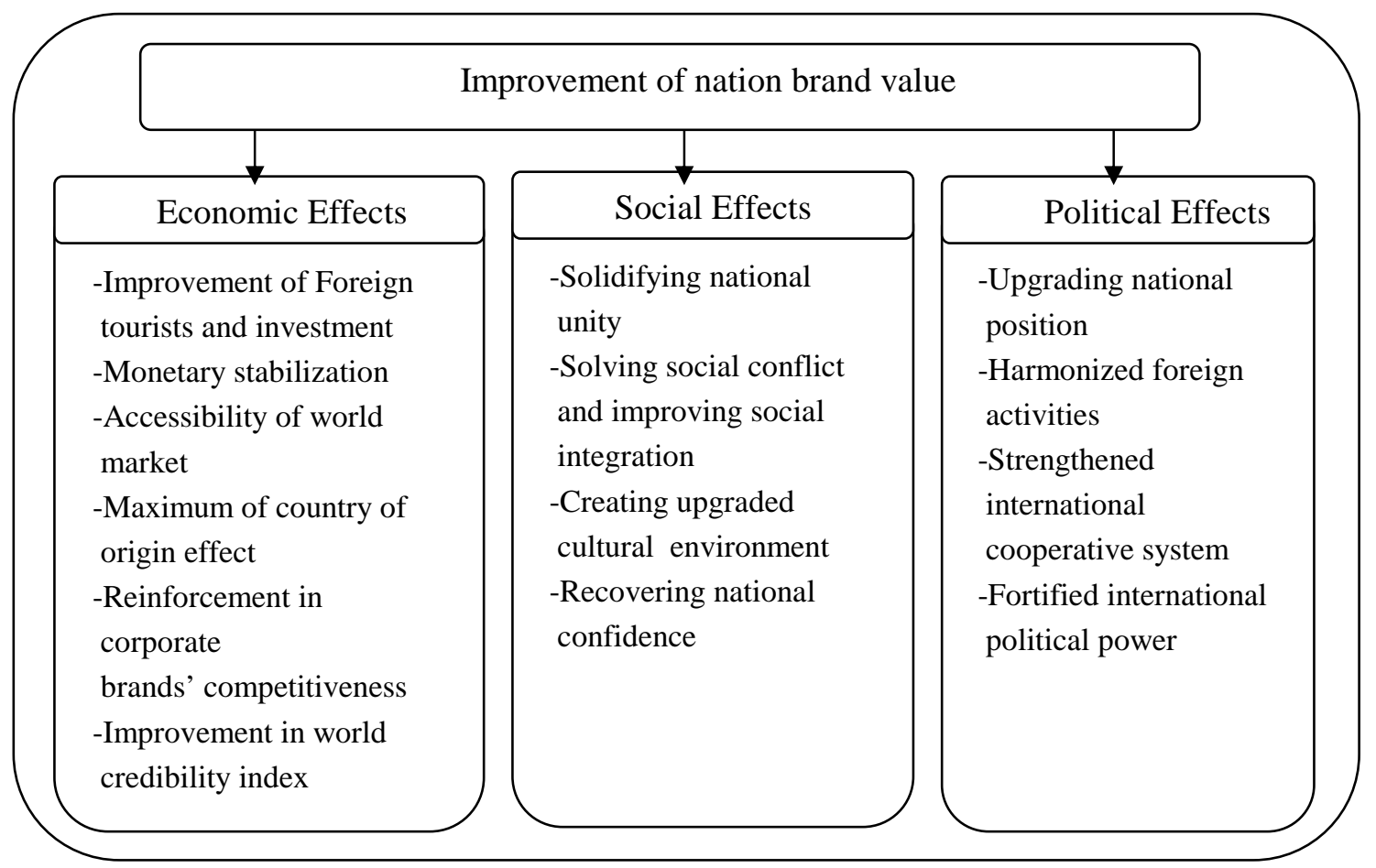

(Source: Cho, 2004:40) 


\subsection{MODELS OF NATION BRANDING}

Existing models - in the context of nation branding - distinguish how a nation brand is developed and managed. Based on four aspects of key nation-branding concept (2.2.5: Fig. 9), models are classified with different categories.

The first group of models focuses on developing the nation brand on the principle of aligning it with a national strategy (see Table 24).

Table 24 Models aligning a nation brand with a national strategy

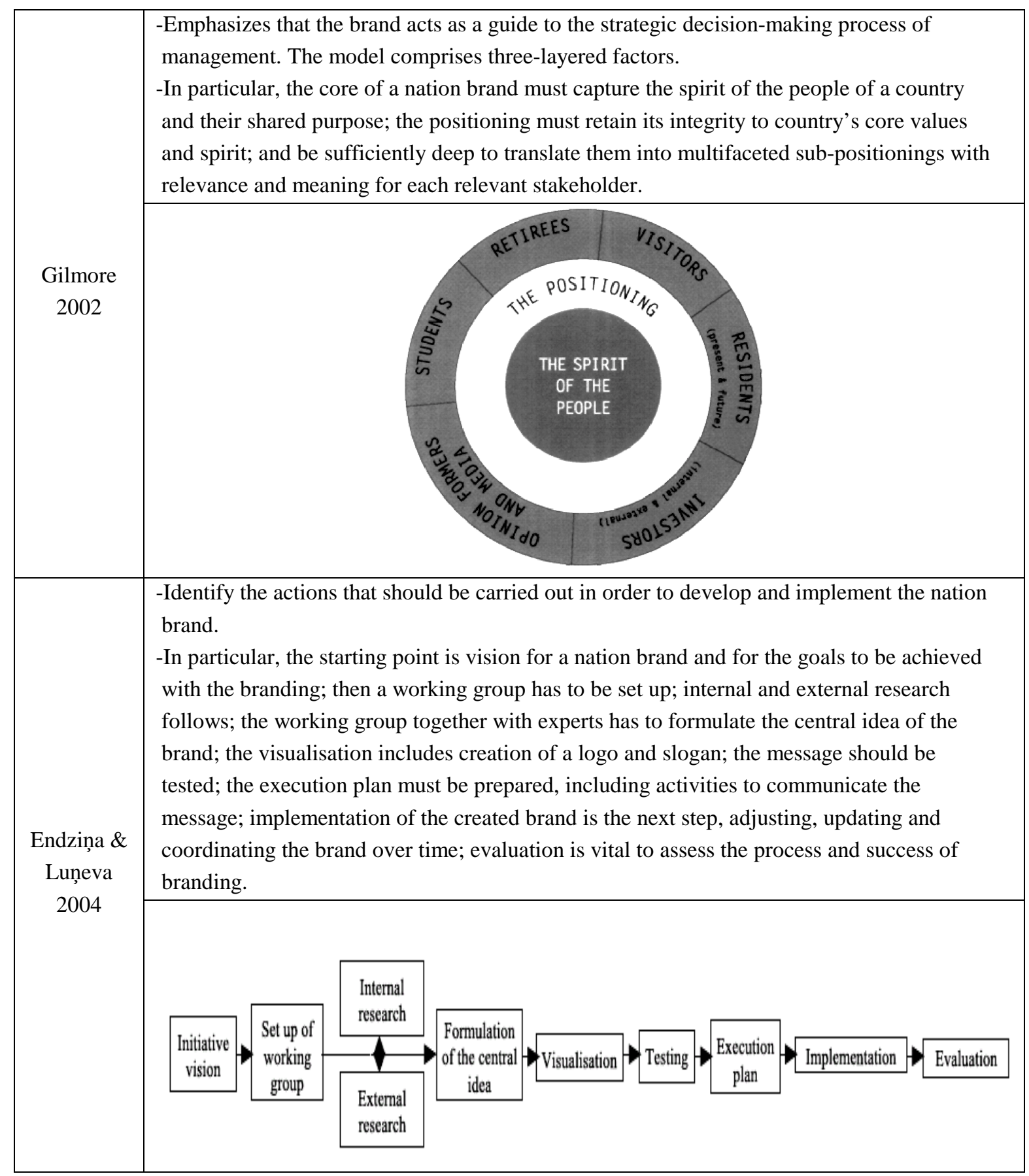




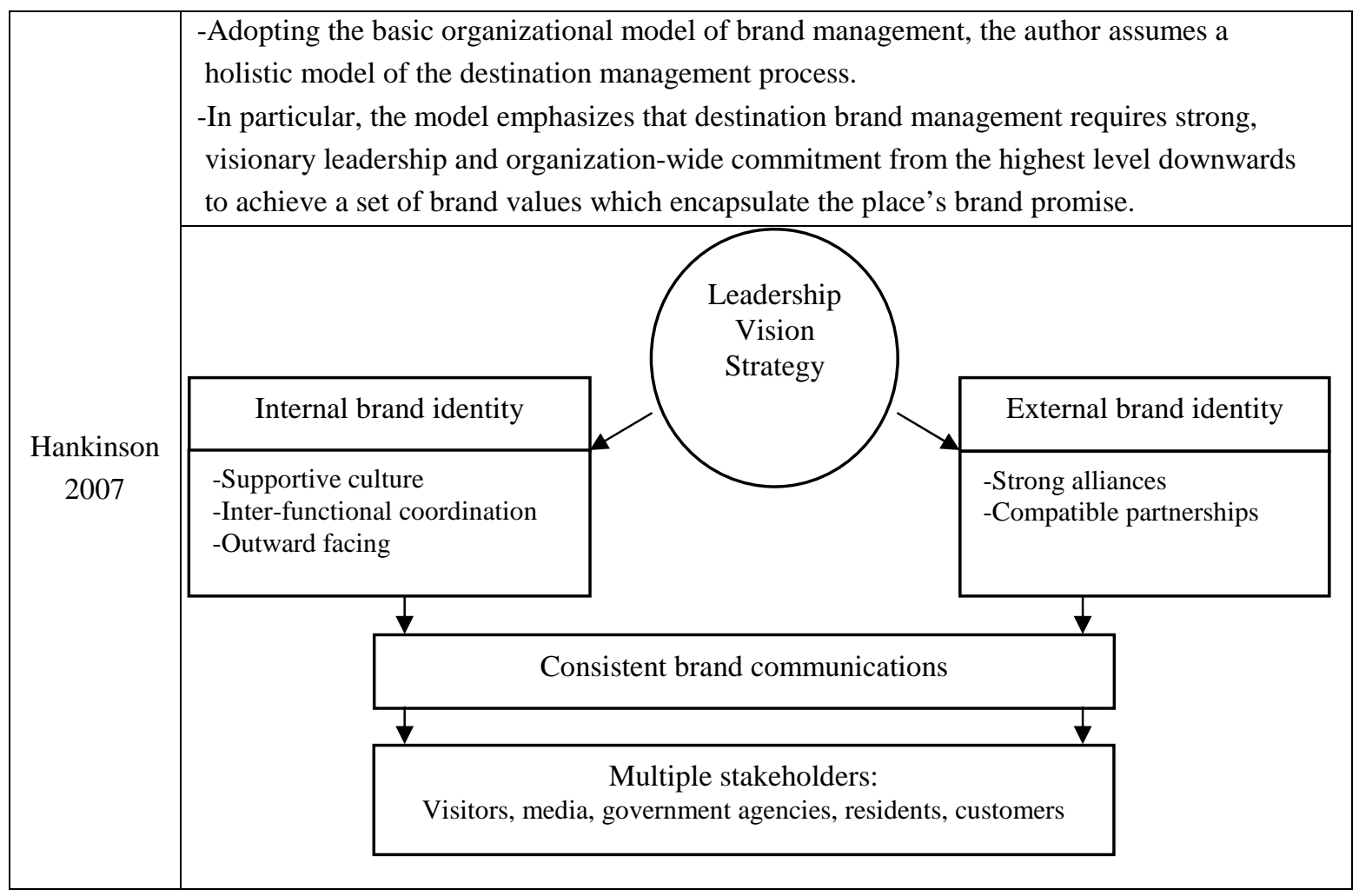

There are a few models currently available to explain how a nation brand is developed through aligning with a national strategy. We adopted three existing models. These characterise the advantages or the disadvantages in building a nation brand. The first model (Gilmore, 2002) emphasizes that the spirit of the people and their shared purpose are at the core of successful nation branding, which is based on the etymological and ontological concepts of nation branding. The second model (Endziña \& Luneva, 2004) takes a strategic management process based on a planning approach. This model considers the importance of vision creation, internal and external researches, implementation and evaluation. However, only a working group among brand actors is involved in this process. Moreover, this model is limited to visualization in a nation-brand development process. The third model (Hankinson, 2007) takes a similar approach to the first and the second models in terms of vision and stakeholders. However, the third model exploits not only internal brand identities but also external brand identities. In particular, leadership and strategy of a nation (or place) are highlighted as the most significant elements in branding. In the first and third models, internal and external stakeholders are considered as the ultimate entity of the process.

The second group of models emphasizes the role of brand strategy in achieving nation (or place) brand equity or value (see Table 25). 
Table 25 Models building a nation brand strategy

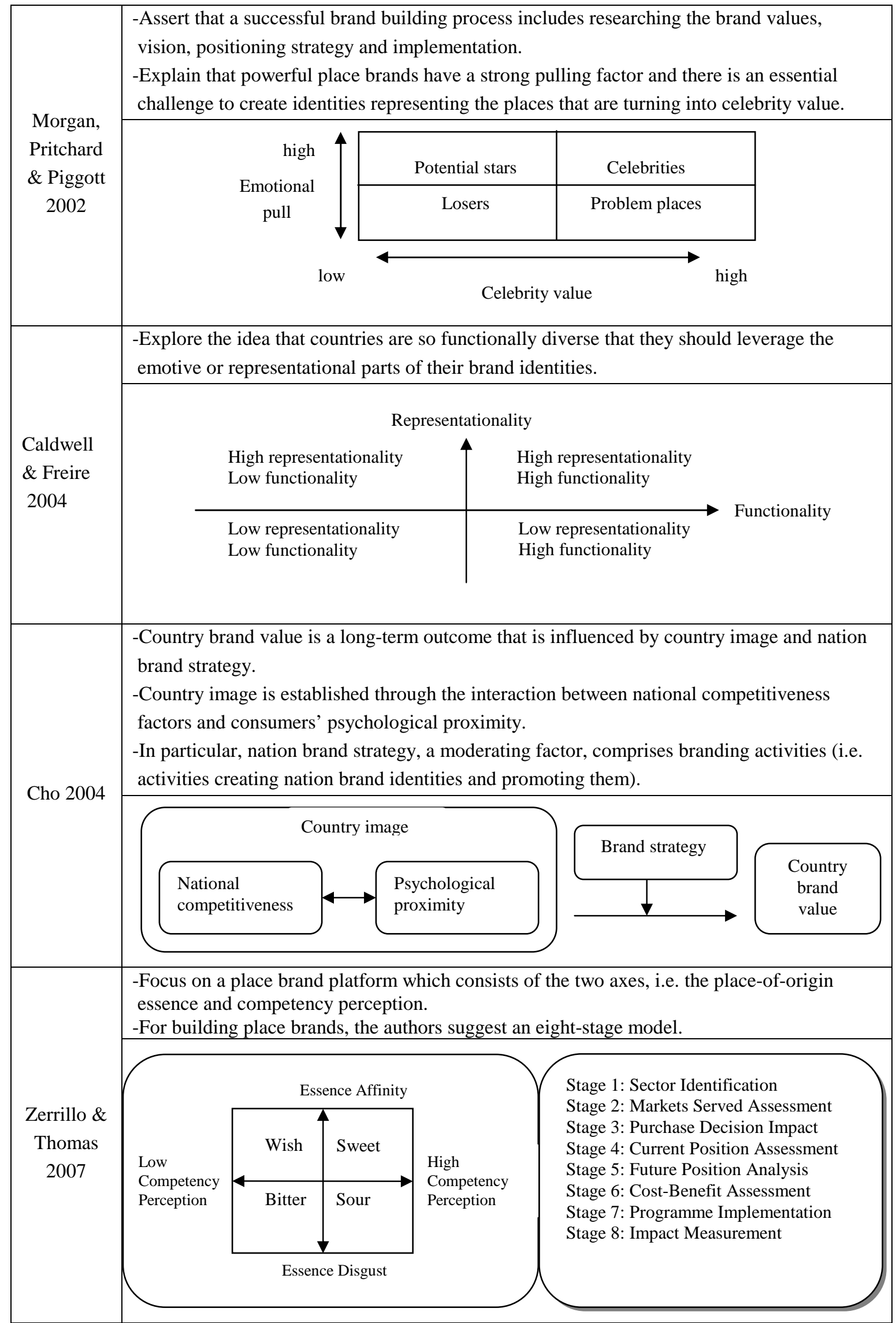


Nation brand strategy is applied to the economic, social, political and cultural development of a country. To provide a criterion for selecting country behaviour and to achieve a nation's development goals, it needs to integrate a nation brand strategy with those disciplines. The first model (Cho, 2004) emphasizes a nation brand strategy based on actors and activities creating identities and communicating them, and defines nation brand value as the outcome. Other models (Morgan et al., 2002; Caldwell \& Freire, 2004; Zerrillo $\&$ Thomas, 2007) focus on the relationship between brand essence and brand perception. Even though they stated the importance of brand management process for successful branding, these models lack in insisting that their brand strategies are enough to reflect a nation's strategy or development strategy.

The third group of models focuses on a nation brand and its dimensions based on brand attributes or reality of a nation (see Table 26).

Table 26 Models building the nation brand identity and image

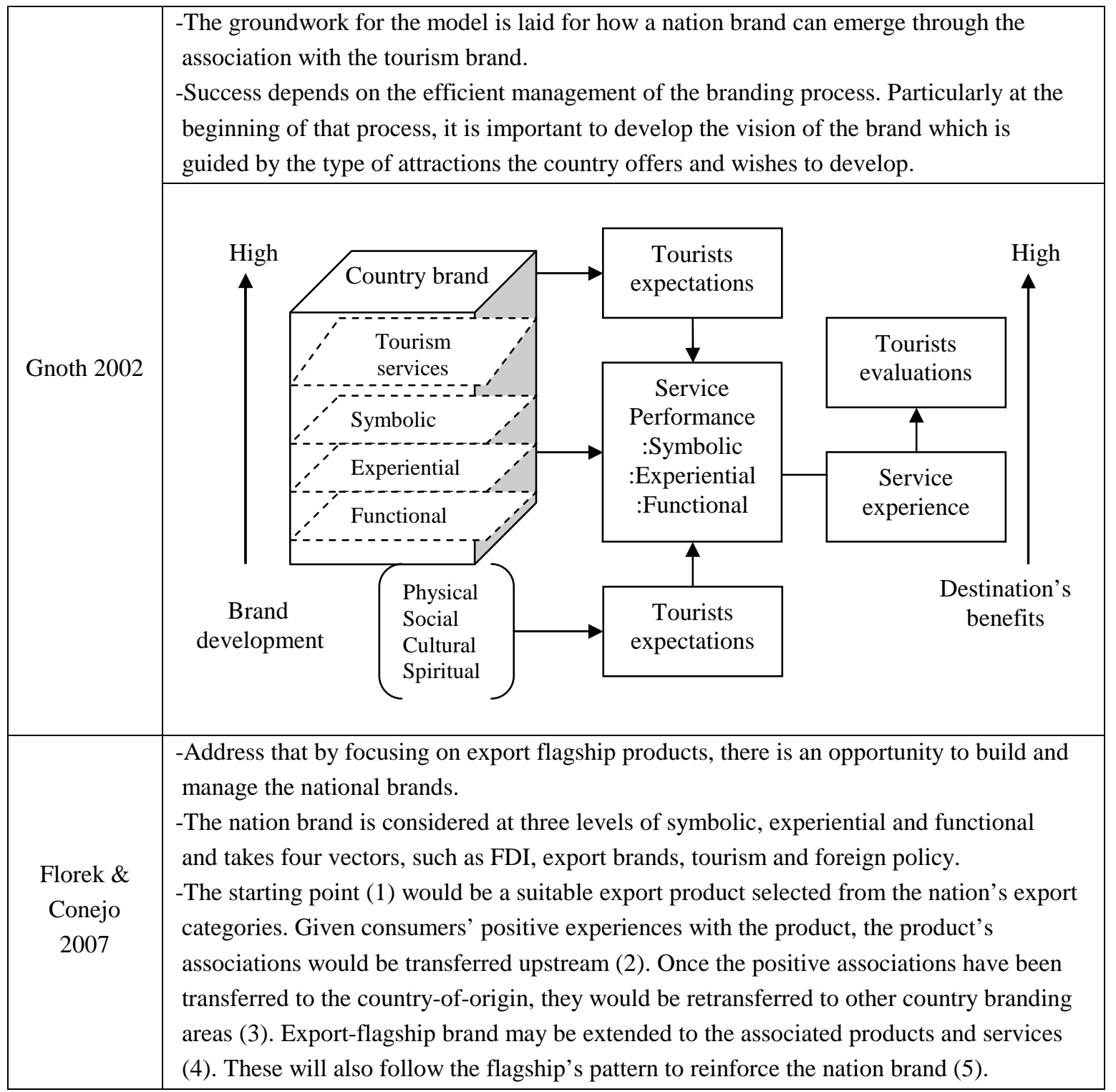




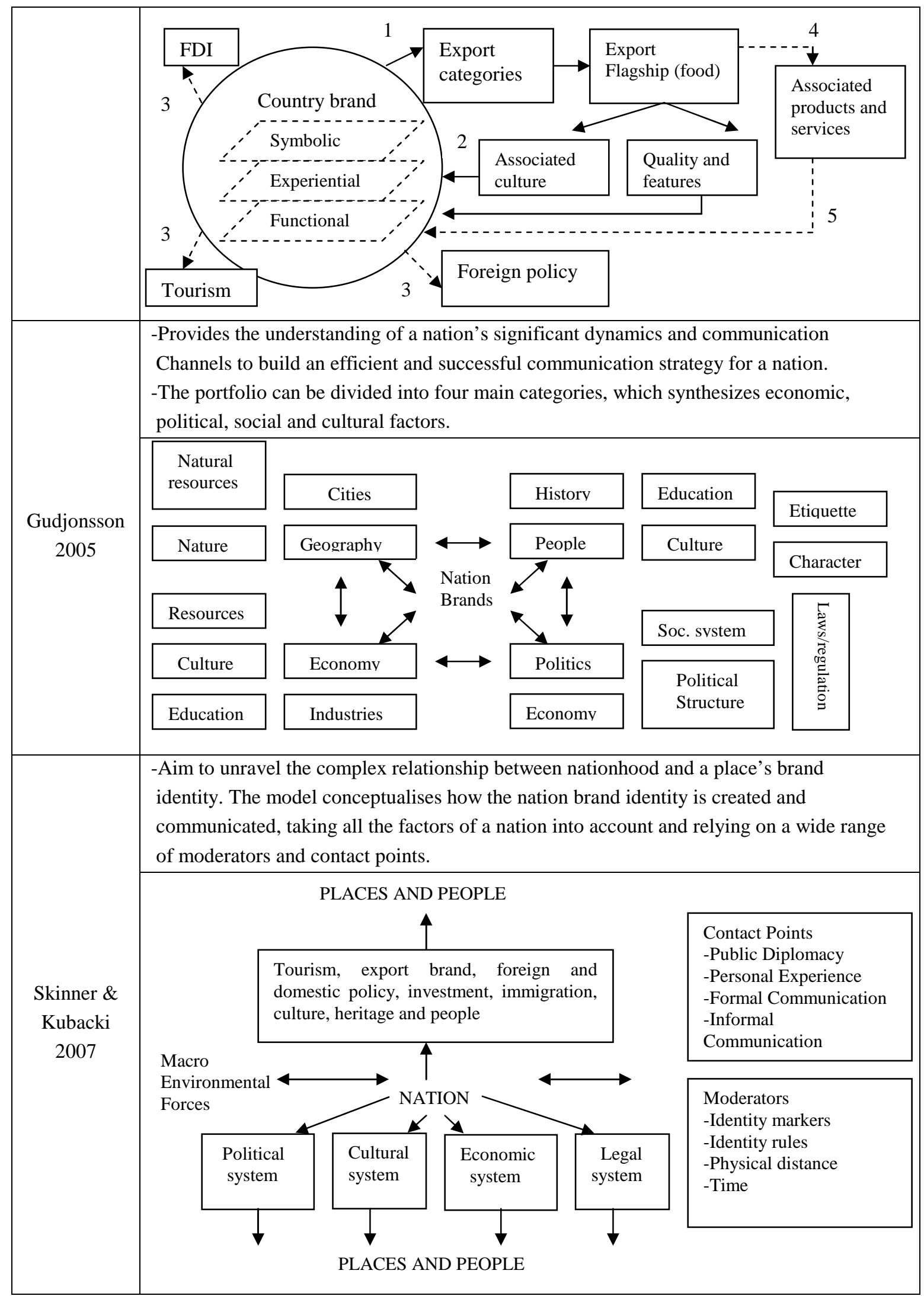

These models all aim to explain how a nation brand is developed through the identitybuilding process and what kinds of brand attributes are involved in the process. While the 
Table 27 Models managing a nation brand behaviour

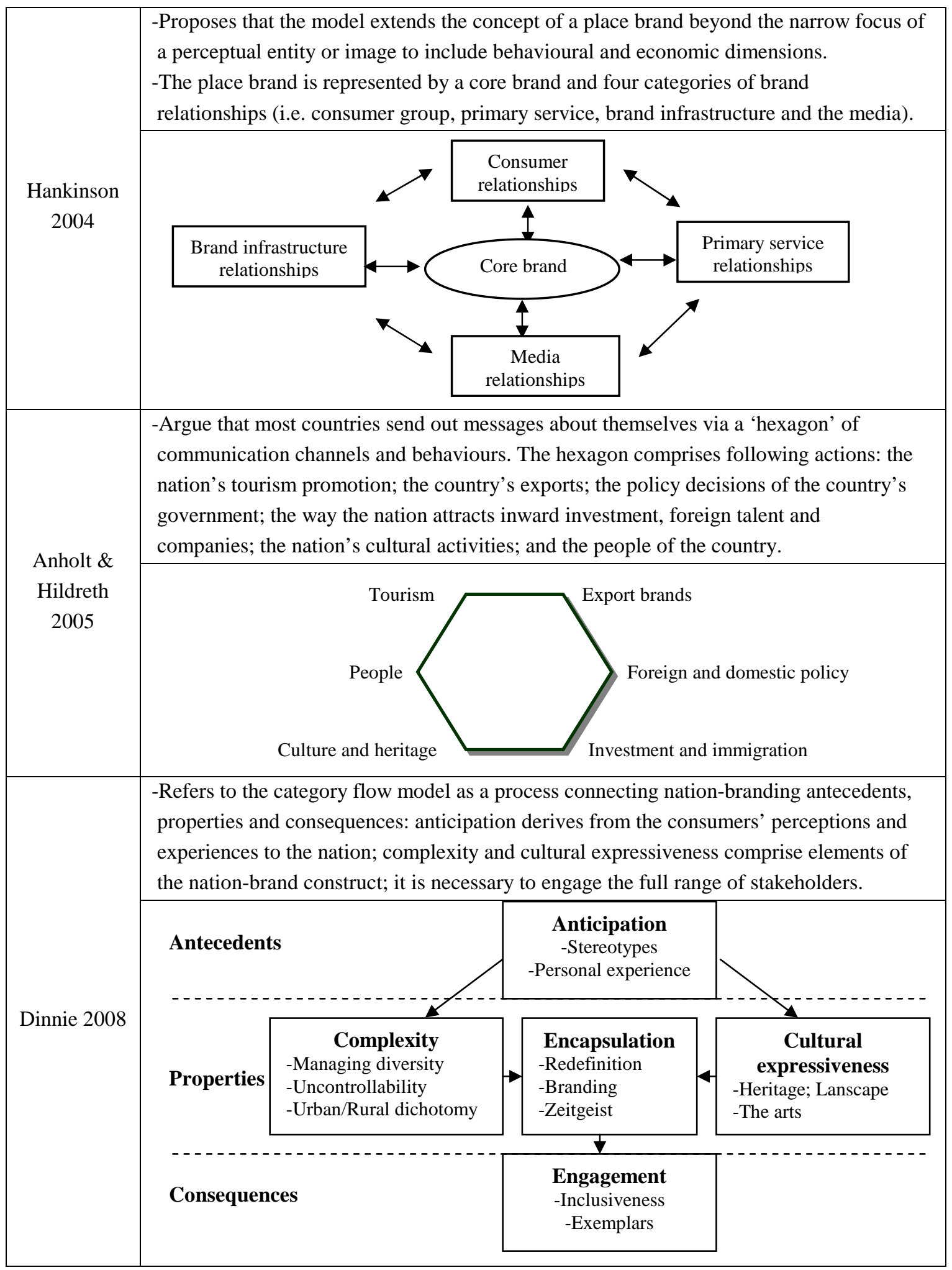

first model (Gnoth, 2002) is limited to a product (e.g. tourism) of a nation brand, the second model (Florek \& Conejo, 2007) explains a nation brand development through a virtual circle of export product, country-of-origin effect and its impacts on other products of a nation brand. Meanwhile, the models (Gudjonsson, 2005; Skinner \& Kubacki, 2007) 
emphasize the importance of national economic, political, social and cultural dimensions in creating the nation's brand identity. In particular, macro environmental forces are considered in the process. The fourth group of models represents the modules that underline the involvement of stakeholders and brand behaviours, emphasizing that the nation brand identity is posited at the core of the process (see Table 27).

When we analyzed them, models highlighted key cause and effect variables in nation branding (Table 28) either implicitly or explicitly. Some models were limited to a conceptualized framework; others were verified qualitatively by empirical evidence.

Table 28 Key variables in nation branding models

\begin{tabular}{|c|c|c|c|}
\hline & \multicolumn{2}{|l|}{ Key variables } & \multirow{2}{*}{$\begin{array}{l}\text { Scope of } \\
\text { model }\end{array}$} \\
\hline & Causes & Effects & \\
\hline Gilmore 2002 & The spirit of its people; the positioning; stakeholders & Citizen value & Conceptual \\
\hline $\begin{array}{c}\text { Endziņa \& } \\
\text { Luņeva } 2004\end{array}$ & $\begin{array}{l}\text { Vision; a working group; internal and external } \\
\text { research; idea formation; visualisation; the message } \\
\text { test; execution plan; implementation; evaluation }\end{array}$ & Nation brand & Conceptual \\
\hline $\begin{array}{l}\text { Hankinson } \\
2007\end{array}$ & $\begin{array}{l}\text { Vision, leadership and strategy; internal and external } \\
\text { brand identity; brand communications }\end{array}$ & Stakeholders & Conceptual \\
\hline $\begin{array}{l}\text { Morgan et al. } \\
2002\end{array}$ & $\begin{array}{l}\text { Brand values; vision; positioning strategy; } \\
\text { implementation }\end{array}$ & $\begin{array}{l}\text { Celebrity value; } \\
\text { emotional pull }\end{array}$ & Conceptual \\
\hline $\begin{array}{l}\text { Caldwell \& } \\
\text { Freire } 2004\end{array}$ & The brand's functionality and representationality & Brand loyalty & Empirical \\
\hline Cho 2004 & $\begin{array}{l}\text { Country image (national competitive factors, } \\
\text { psychological proximity); brand strategy }\end{array}$ & $\begin{array}{c}\text { Country } \\
\text { brand value }\end{array}$ & $\begin{array}{l}\text { Conceptual; } \\
\text { Empirical }\end{array}$ \\
\hline $\begin{array}{c}\text { Zerrillo \& } \\
\text { Thomas } 2007\end{array}$ & The place essence; the place competencies & Customer intimacy & Empirical \\
\hline Gnoth 2002 & $\begin{array}{l}\text { Brand experiences (functional, experiential and } \\
\text { symbolic); service performance and experience }\end{array}$ & $\begin{array}{l}\text { Destination's } \\
\text { benefits }\end{array}$ & Conceptual \\
\hline $\begin{array}{c}\text { Florek \& } \\
\text { Conejo } 2007\end{array}$ & $\begin{array}{l}\text { Three level of country brand (symbolic, experiential } \\
\text { and functional); export product; consumers } \\
\text { experience; export flagship pattern }\end{array}$ & $\begin{array}{l}\text { National brands } \\
\text { and nation brand }\end{array}$ & Empirical \\
\hline $\begin{array}{l}\text { Gudjonsson } \\
2005\end{array}$ & $\begin{array}{l}\text { The people and their culture; politics, structure, } \\
\text { government and policies; the economy, industries, } \\
\text { companies and brands; geography }\end{array}$ & $\begin{array}{l}\text { The nation's } \\
\text { compatibility and } \\
\text { prosperity }\end{array}$ & Empirical \\
\hline $\begin{array}{c}\text { Skinner \& } \\
\text { Kubacki } 2007\end{array}$ & $\begin{array}{l}\text { National system; macro environmental factors; } \\
\text { physical distance; time; identity markers; rules }\end{array}$ & $\begin{array}{l}\text { Nation brand } \\
\text { identity }\end{array}$ & Conceptual \\
\hline $\begin{array}{l}\text { Hankinson } \\
2004\end{array}$ & $\begin{array}{l}\text { Core brand (personality, positioning, reality); brand } \\
\text { relationship (consumer group, primary service, brand } \\
\text { infrastructure and the media) }\end{array}$ & Place brand & Conceptual \\
\hline $\begin{array}{c}\text { Anholt \& } \\
\text { Hildreth } 2005\end{array}$ & $\begin{array}{l}\text { Tourism; exports; the policy decisions; inward } \\
\text { investment; culture and heritage; the people }\end{array}$ & $\begin{array}{l}\text { competitive } \\
\text { identity; reputation }\end{array}$ & $\begin{array}{l}\text { Conceptual; } \\
\text { Empirical }\end{array}$ \\
\hline Dinnie 2008 & $\begin{array}{l}\text { Anticipation; complexity; cultural expressiveness; } \\
\text { encapsulation }\end{array}$ & $\begin{array}{l}\text { Engagement by } \\
\text { stakeholders }\end{array}$ & Conceptual \\
\hline
\end{tabular}

(Note: The variables have derived not only from the models directly but also the contents of the literature) 
This research has observed models explaining key concept of nation branding. Some models (Endziña \& Luneva, 2004; Hankinson, 2007) stress the brand management perspective. Even though they have highlighted the importance of the nation brand development aligning with national strategy, and adapted it to the organizational model of branding and strategic brand management, the models lack in explaining a nation brand management as an advanced brand theory.

In particular, for nation branding that facilitates effectively the sustainable competitiveness of a nation, a model needs to explain not only the causal variables in nation branding but also performance outcomes with respect to the sustainable competitiveness. However, a few models (Cho, 2004; Morgan et al., 2002) articulate the effect of nation branding in terms of nation brand equity or value. They still lack in explicating performance in nation branding in the context of strategic management as an umbrella concept for sustaining a nation's holistic brand system.

\subsection{CONCLUSION}

Theories and models of nation branding and sustainable competitiveness of nations were reviewed, exploring the concepts of nation branding and the sustainable competitiveness; and the relevance of existing models in line with the key concept of nation branding.

The concept of nation branding has been both implicitly and explicitly defined, which relates to the notions from nation-as-brand to nation brand management. The nation-asbrand notion is discoursed on the etymological, the ontological and the ecological perspectives of a nation. Nation brand management is relevant to a nation's ability to develop and manage a nation brand. Strategic brand management and the systematic process approach are highlighted to innovate a nation's current economic, social, political and cultural realities and to align them with a strategy for building a nation's identity and improving national image and reputation. These basic concepts in nation branding have evolved with the academic disciplines of marketing a country-of-origin and a place and of international relations (i.e. a branding approach to public diplomacy).

Aiming to define the role of nation branding and create a strategic management tool on nation branding for the sustainable competitiveness of nations, we have addressed the key concept of nation branding, in particular, focusing on the role of nation branding and a strategic management approach to nation branding. That is, nation branding combines the three domains of country-of-origin, place development and public diplomacy, creates a nation brand as an umbrella brand encompassing from country name through to all the collected activities for national brands, and ultimately achieves nation brand effects both internally and externally. In particular, this process needs an umbrella branding and a holistic and strategic brand management approach that can sustain a nation brand system. 
For this process, we highlighted four aspects of nation branding, emphasizing the interdisciplinary and systematic branding approach. First, to manage a nation brand systematically, nation branding needs to align a nation brand with a national strategy. Second, a nation brand strategy should be aligned with the nation's economic, political, social, and cultural development strategies. Third, the nation brand identity and image should be created based on the nation's reality. Moreover, nations need to engage in consistent brand behaviour that encompasses all aspects of the nation brand.

These concepts of nation branding need to be determined with respect to sustainable competitiveness. The first notion relates to globalization as a main driver of nation branding. Nation branding needs to consider how to restructure the country and how to manage globalization, in particular, a globalized marketplace that provides an external environment for the nation brand. Competitiveness is a country's ability to produce competitive resources based on national and international needs, and to maintain a competitive position in global markets. In addition, it is an ongoing process to sustain a nation's economic and social development level for its people. To sustain the competitiveness of nations, nation branding is an imperative. That is, the competitiveness of nations is the nation's ability to create and sustain competitive advantage and national development. Nation branding is to take a strategic, systematic management approach to creating and sustaining them. Moreover, as we explored the etymological, ontological, and ecological concepts, the concept of nation branding needs to show the entire process of why and how a nation creates a nation brand system, to sustain it and achieve the nation brand effects ultimately expressed as nation brand equity. In this holistic process of creating and sustaining a nation's competitiveness, nation branding plays its key role.

To define the role of nation branding and create a strategic management tool on nation branding for the sustainable competitiveness of nations, we have asked: how does nation branding contribute to the sustainable competitiveness of nations; and how can we develop a comprehensive framework for nation branding that facilitates effectively the sustainable competitiveness of a nation. Based on the key concept of nation branding, existing models fail to explain either the role of nation branding that influences the sustainable competitiveness of nations or the relationship between nation branding and sustainable competitiveness. Therefore, we conclude: a new model of nation branding needs to adopt a strategic nation branding approach in terms of both strategic management and ongoing process of nation branding that sustains a nation's competitive advantage, development and brand equity. 


\section{CHAPTER 3 A NATION-BRANDING MECHANISM MODEL}

\subsection{DEVELOPING A NATION-BRANDING MODEL}

\subsubsection{CRITERIA}

Nations compete in the competitive global environment in order to sustain national economic and social developments for their people. To achieve these development levels, nations have been building their abilities to produce goods and services to match global market needs. These represent a nation's sources of competitiveness. As the main driver for nation branding, globalization is a domain providing an external environment where nations can challenge to take opportunities for competitive advantage. A successful performance in nation branding, therefore, can be discussed by assuming a nation's competitiveness in the global market environment. In particular, a notion of competitiveness is denominated not as a static concept, but rather as an ongoing process. Porter (1998) has argued that competition is constantly changing and evolving in which new products, new ways of marketing, new production processes, and completely new market segments emerge. There is an urgent need to explain the dynamics of competitiveness, integrating input, process and outcome (Buckley et al., 1988). Competitive advantage is sustained through the integrated framework underlying the sequential determinism of the source of advantage, positional advantage and performance outcomes (Day \& Wensley, 1988). In sustaining a nation's competitiveness, therefore, it is important to consider that a nation-branding model is:

- Suitable to explain an interwoven process of producing competitive resources and simultaneously corresponding to the global market environment

- Suitable to address the dynamics integrating a sequence of input, process encompassing the sources of the competitiveness, and performance outcome.

Branding and brand-based differentiation are powerful means for creating and sustaining competitive advantage (Aggarwal, 2004). Nation brands that stakeholders prefer achieve competitive advantage in the marketplace, which leads to a stakeholder-based country value. Nation branding is to create the sustainable competitiveness of nations and ultimately to achieve nation brand value. That is, it is all about creating and managing nation brand equity.

Reflecting on the nation-branding context related to country-of-origin, place development and public diplomacy, management of the nation brand equity must be in line with a strategic approach to managing a nation brand. In terms of strategic management of a nation brand, nation branding should develop a sustainable brand system and manage that system holistically. The primary role of nation branding is to perform nation brand management effectively, and to align a nation brand with a nation's strategy and direction. 
Moreover, to achieve a nation's sustainable development, it is important to develop a nation brand strategy that applies to a nation's economic, political, social, and cultural development strategy. For managing nation brand equity effectively, therefore, a model should be:

- Suitable to align a nation brand with a nation's strategy and direction

- Suitable to develop a nation brand strategy that applies to sustainable development.

A nation's image (or reputation) and identity are the crucial parts of nation brand equity. Nation branding is to manage the national identity and image, and aims to improve these for the sustainable competitive advantage of the country. In managing a nation brand identity and image, it is necessary to develop a unique set of brand attributes or attractions that are compatible with market competition and meet market needs. For creating the brand's uniqueness and attraction, the most important principle is to take a strategic approach based on the reality of the country, namely a country's essence and competence. In particular, changes in the reality are driven by the extent to which the internal resources and the external environment are transformed. To manage a nation's identity, image and reputation as nation brand equity, therefore, it is important to build a model that is:

- Suitable to deal with creating a nation's identity and image based on the reality of the country

- Suitable to reflect the dynamic phenomenon of the reality change both internally and externally driven.

A sustainable nation-brand system is managed by the country's behaviour, encompassing branding actors and their activities, termed a nation brand behaviour. To align a nation brand with a nation's strategy and direction for sustainable competitiveness, nation brand behaviour is important and therefore highlighted. In developing a nation brand strategy and managing the identity and image, nations need to focus on ensuring consistent and coherent brand behaviour. To explain performance in nation branding, therefore, a model should be:

- Suitable to address a nation brand behaviour, i.e. branding actors and their activities 


\subsubsection{TYPOLOGY OF A MODEL: factor or process model}

A strategic framework or model encompassing the systematic and comprehensive approach, according to Schmitt and Simonson (1997:43), offers a clear guideline for enhancing an organization's or brand's appeal, and provides value for the organization and its multiple constituents. Morecroft, Sanchez and Heene (2002) insisted that modelling can elucidate logical relations among key success factors. Meanwhile, Gill and Johnson (2002) asserted that theory is established by explaining the cause and effect relationship between variables. According to Cooper and Schindler (2003:164), "causation" refers to a kind of prediction and the causal inferences allow us to build knowledge of presumed causes over time. Therefore, it is important to highlight the cause-and-effect relationship logically during a model building.

A model is defined as an external and explicit representation of a part of reality as seen by the people who wish to use that model to understand, to change, to manage and to control that part of reality (Pidd, 1996). Meanwhile, according to Cooper and Schindler (2003), the cause-and-effect relationship is often less explicit. In particular, Perry and Robertson (2002) explained technically the causalities using two forms: implicit and explicit causality. The former assumes that some degree of causality exists between variables, and the latter is verified through manipulating statistical procedures to measure variables in the cause-and-effect sequence (Ibid).

With respect to an input-process-output model for performance measurement, researchers have explained models classified by a dyadic perspective, i.e. variance (or factor) or process model (Table 29).

Table 29 Characteristics of a factor and a process models

\begin{tabular}{|c|l|l|}
\hline \multirow{2}{*}{ Definition } & \multicolumn{1}{|c|}{ Factor Model } & \multicolumn{1}{|c|}{ Static } \\
\cline { 2 - 3 } & $\begin{array}{l}\text { The cause is necessary and sufficient } \\
\text { for the outcome }\end{array}$ & $\begin{array}{l}\text { Causation consists of necessary condition in } \\
\text { sequence; chance and random events play a role }\end{array}$ \\
\hline Elements & Independent and dependent variables & Discreted, sequential entities \\
\hline Assumptions & $\begin{array}{l}\text { Outcome will occur when necessary } \\
\text { and sufficient conditions are present }\end{array}$ & $\begin{array}{l}\text { Outcomes may not occur (even when conditions } \\
\text { are present) }\end{array}$ \\
\hline
\end{tabular}

(Source: Markus \& Robey, 1988)

A variance model focuses on inputs and outcomes of change and explains the causal relationship between them by testing the empirical association and then inferring the relationship at a statistical confidence level (Mackenzie, 2000; Van de Ven \& Huber, 1990). Compared to a variance model, a process model explains discrete or discontinuous phenomena having a qualitatively different "change of state." While a factor model (a variance model) does not provide evidence of the phenomena (events, actions, and so on) between variables, the process approach explains "how or why" the predictors and 
outcomes are related (Newman \& Robey, 1992). In particular, researchers (Van de Ven \& Huber; 1990; Abbott, 1988) insisted that the process approach is applicable to explaining the temporal order and sequence in which a discrete set of events occurred based on a story or historical narrative.

Reflecting on nation-branding models (section 2.4), the dyadic approach has been applied to the existing nation-branding models. As shown in Table 30, some of models adopt a factor-based approach, explaining the causal relationship between independent and dependent variables, or the interaction between variables. Others present a process-based model. They explain how and why the predictors and outcomes are related, presenting sequential events based on a temporal scope.

Table 30 Nation-branding models based on Factor or Process model

\begin{tabular}{|l|l|}
\hline \multicolumn{1}{|c|}{ Factor model } & \multicolumn{1}{c|}{ Process model } \\
\hline Morgan, Pritchard \& Piggott (2002) & Gilmore (2002) \\
Hankinson (2004) & Gnoth (2002) \\
Caldwell \& Freire (2004) & Endzina \& Luņeva (2004) \\
Cho (2004) & Florek \& Conejo (2007) \\
Anholt \& Hildreth (2005) & Hankinson (2007) \\
Gudjonsson (2005) & Zerrillo \& Thomas (2007) \\
Skinner \& Kubacki (2007) & Dinnie (2008) \\
Zerrillo \& Thomas (2007) & \\
\hline
\end{tabular}

\subsubsection{SELECTION OF A MODEL}

A process is designed to produce a specified output (Davenport, 1994). Organizations are open systems that are in continual interaction with their environments for resources and there are processes of adaptation and change which can be both operationalized and managed (Mackenzie, 2000). Process studies are fundamental to developing and testing the theories of organizational adaptation, change, innovation and redesign (Van de Ven \& Huber, 1990:213). For instance, the Scandinavian School came up with the model explaining stages in the internationalization process that involve a time sequence developing in a logical and linear pattern (Ietto-Gillies, 2005). An organizational process of adaptation and change is applicable at the country level. Porter (1998) has argued that it needs to explain the role of the nation in the innovation process. In respect of sustainable competitiveness of nations or organizations, Buckley, Pass and Prescott (1988) have asserted that it is a useful measure of competitiveness to include the competitive process management.

To decide an appropriate nation-branding model with respect to the sustainable competitiveness, we first highlight two important aspects of time and planning. The competitive context changes over time. The image and reputation of nations are changed over time by stakeholders' perceptions. A nation's reality and identity are restructured and recreated over time. Therefore, nation brand equity is actively managed over time by 
reflecting a changing notion and reinforcing the nation brand definition. The time dimension is influential in country-of-origin effects, with strategic market planning relying on a place's economic development, and on public diplomacy aiming to promote and maintain brand relationship in international environments. To reflect events connected with nation branding, a time line showing the sequence of the actions and the events needs to be developed (Endziña and Luneva, 2004). As Szondi (2007) has argued, nation branding has been evolving for more than decades, and collective experience enables us to identify patterns of nation branding. Developing a nation brand is a long-term and complex process (Florek, 2005).

Competitiveness without sustainability is illusionary (Ritchie \& Crouch, 2005). Sustainability is an evolutionary process of improving the management system and, in an evolutionary system, planning is concerned with the future and involves the active control of a system's environment (Bagheri \& Hjorth, 2007:84-85). Branding has been considered as a managed process whereby management decides on a strategic plan (Gnoth, 2002:270). Endziņa and Luñeva (2004:95) pointed out that traditionally place branding has been more accidental than a deliberately planned action, but that thoughtful economic planning of nation branding has been applied at least for a decade. In nation branding, Dinnie (2008) has argued that nations that fail to plan the strategic management of their nation brand may struggle to compete with nations that take a more proactive approach to nation branding.

In defining the role of nation branding with the notions of sustainability and management (2.2.5), our research has highlighted to align a nation brand with a national strategy and to develop a nation brand strategy. Within this context, Anholt (2008) has emphasized the importance of aligning the innovation to a strategy for enhancing national reputation. According to him, that makes the innovation more focused and more appropriate to the needs and resources of the country, and brand management should be treated through the process of planning or economic development of a nation (Ibid). In line with a planning approach, Kotler et al. (1993) have asserted that strategic market planning has emerged as a promising integrative process linking a place's potential competitive advantages to overall economic development goals. They have argued that the strategic planning process aims to prepare plans and actions that integrate the place's objectives and resources with its changing opportunities (Ibid). Endzina and Luneva (2004) have adopted a planning approach to a nation-branding development model. Based on time and planning, a process-based model is applicable to explaining why nation branding is necessary for sustainable competitiveness of nations and how it brings effectiveness.

Meanwhile, different countries have adopted different strategies in order to confront the specific challenges they face and to differentiate themselves on the world stage (Dinnie, 2008:23). In predicting where countries are going, according to Vietor (2007), it is useful to consider a country's trajectory (i.e. a country's developmental pathway, cutting through time with a lot of momentum). Each country develops in a particular direction, based on its current strategy, organizational structure and context, which can sometimes change 
abrubtly under new political, economic and social conditions (Vietor, 2007:3). Van de Ven and Poole (1990) have argued that it is necessary to identify which development path leads to success or failure for different kinds of innovations. Within these notions, we highlight a mechanism-based process theory. According to Van de Ven (1992), the process is regarded as a "black box" in which undefined processes occur. Extending process theory into a mechanism-based view, Cho (2006:101) has argued that the process automatically "streams out" from a mechanism, and asserted that the mechanism-based process view is about the multifaceted and holistic approach focusing on the dynamics and operational principles of an organization that drive a specific process.

In the mechanism-based process view, a value-creating process model (Fig.16) is presented. The value-creating process model explains how an organization can achieve sustainable competitiveness by creating more valuable resources and environments, aligning them with the organization's strategic management process. This model assumes that sustainable competitiveness is created by a mechanism composed of a bundle of behaviors, such as vision creation, goal setting, environmental and resources analysis, strategy development, restructuring and the creation of environment and resources, and implementing the organization's strategy along with environment and resources created.

Fig. 16 A value-creating process model

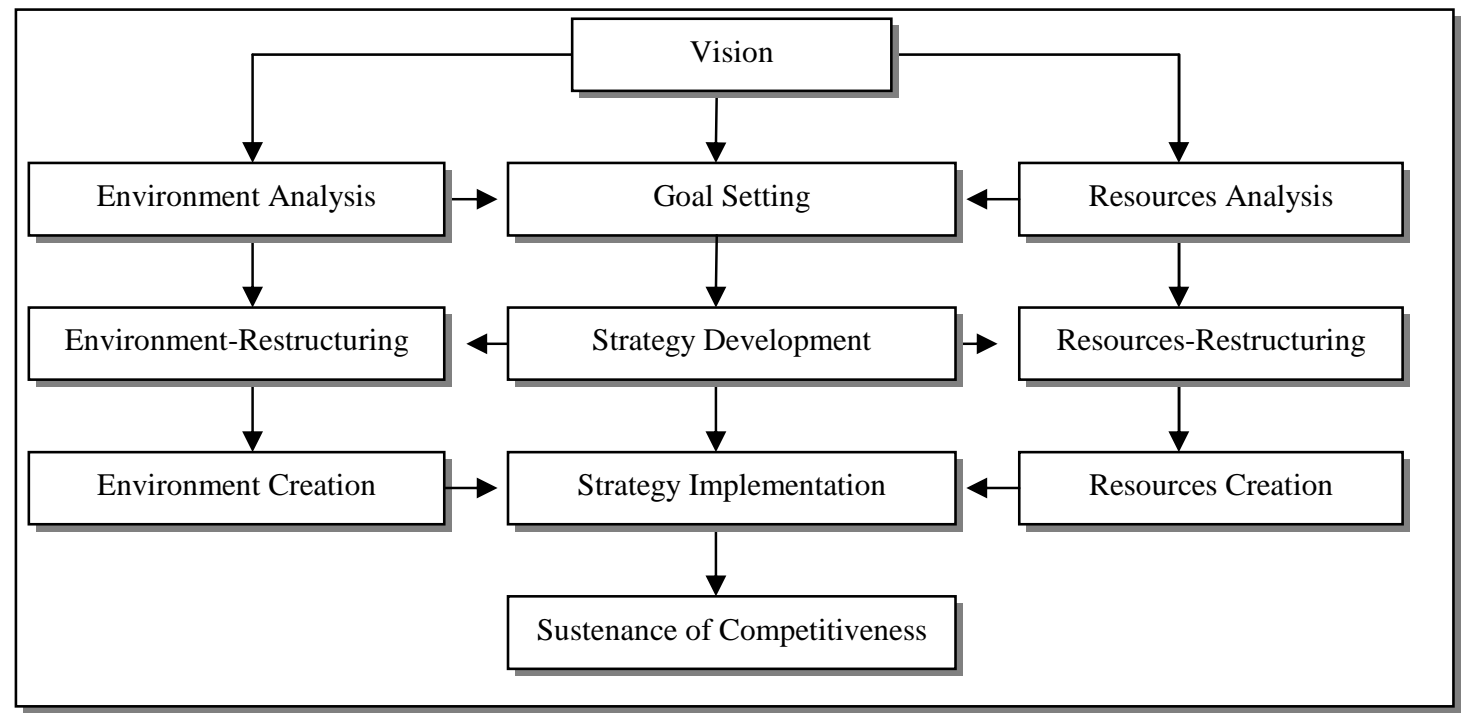

(Source: Cho, 2006:314)

This value-creating process view (Fig.16) characterises some similarities and differences compared to the strategic planning process view (Fig.8, p.25). Both of them emphasize the process-based and mechanism-based perspectives. The planning process is defined as a set of generic activities that occur across an entire problem-solving sequence (Bryson \& Bromiley, 1993:320). Strategic planning can improve the business performance of tangible and intangible effects on an organizational mechanism (Huysman et al., 1994). Kotler, Haider and Rein (1993:80) have asserted that the strategic planning process is highly likely to succeed in places where consensus-building mechanisms operate. However, 
the value-creating process model argues that while a process is a stepwise sequence of activities which stem from causes and arrive at effects of a phenomenon, a mechanism comprises parts (subjects, environment and resources) providing causal explanations within the contextual events (Cho, 2006). The parts have been identified by both the activities that are producing a change and the actors that engage in the activities (Machamer et al., 2000). The mechanism derives from behavior by interactions between some parts (Glennan, 1996). While the strategic planning process view highlights a mechanism implicitly, the value-creating process model explains a mechanism-based view explicitly.

Historically, market and place have been tightly interwoven (Zukin, 1993:6). There is a certain type of market environment that facilitates competitive advantage in terms of product performance and high quality (Hooley et al., 1988). In a competitiveness context, research has contended that not all resources can create competitive advantage (Milfelner et al., 2008; Porter, 1998). To gain sustainable competitiveness, an organization or a nation needs unique, durable and appropriated resources (Porter, 1998; Collis \& Montgomery, 1995; Day \& Wensley, 1988) and should think about how to exploit the characteristics of its resources. Within these resources and market environment contexts, the strategic planning process model provides an important notion that approaches for place development and improvement, if they are to succeed, must recognize dynamic global forces and use the tools of business because many places are competing for resources and must be both market-conscious and market-driven (Kotler et al., 1993:76).

However, while the strategic planning process highlights to strengthen the capacity of places to adapt [author highlights] to the changing marketplace, the value-creating process model distinguishes the environment-creating organization from the environment-adapting organization. While the latter limits itself to just adapting to a new environment, the former creates a new environment and resources based on a reciprocal interaction through mechanism-based ${ }^{3}$ value-creating process. According to Lorino and Tarondeau (2002), value creation and competitive advantage can only be achieved by building competences (i.e. the ability to sustain coordinated deployments of resources) in using resources. However, when both the internal confidence and the external performance of a country are carefully managed in tandem, they help each other along and create accelerated change of the country (Anholt, 2005a:11). Superior resources and market position are mediated jointly by strategic choices and then converted into superior performance outcomes (Day, 1990). In identifying strategic processes, process analysis and strategic analysis are necessarily intertwined (Lorino \& Tarondeau, 2002). The value-creating process model encompasses these aspects for the strategic management process of a nation and a nation brand.

Value is an intangible created when people reckon that a brand offers them something worthwhile, and branding is a way of signalling how an organization aligns its goals and

${ }^{3}$ Cho $(2006$; 1997) refers to it as 'The Environment-Creating Mechanism.' 
abilities with the demands of its stakeholders (Anholt \& Van Gelder, 2003:57). As a brand is a value enhancer, nation branding is simply a value-enhancing process. To create and increase a nation's value, nation branding needs to galvanize how nations align their goals and abilities with respect to stakeholders' needs. In particular, nation branding ultimately aims to sustain the competitiveness of nations. In sustaining a nation's competitiveness, a nation-branding model needs to satisfy two criteria: suitable to explain an intertwined process of producing competitive resources and simultaneously corresponding to the market environment; suitable to address the dynamics integrating a sequence of input, process encompassing the source of advantage and positional advantage, and performance outcomes. Branding should be a strategic process that is visionary and integrates crossfunctional activities in the value-adding process (De Chernatony, 2001:32). For a process to be a source of sustainable competitiveness, a planning process requires a more comprehensive and systematic approach (Ritchie \& Crouch, 2003). Moreover, a strategic process must have a substantial impact on some aspects of strategic performance and must be able to create value on a sustainable basis (Lorino \& Tarondeau, 2002:136-37).

The value-creating process model (Cho, 2006) highlights the transformation of an environment-adapting organization into an environment-creating organization through a reciprocal process of creating new environment and resources. Moreover, the model emphasizes how an organization sustains its competitiveness by aligning the organization's vision, goal and strategy based on a mechanism of restructuring and creating resources and an environment through the organization's actors. In the previous chapter, we highlighted that to sustain the competitiveness, a nation needs to build and restructure sources of competitive advantage based on reality of the country (i.e. brand identities and images). To create and manage these competitive identities and images, moreover, our research has emphasized an important aspect of managing nation brand behavior. Principally, we emphasized that nation branding needs to take a strategic and systematic approach to sustaining a nation's brand system and ultimately achieving nation brand effects both internally and externally. Within the systems approach, the mechanisms ensure that an individual brand is managed in a consistent manner (Mihailovich, 2006:245), and derived from intellectual activities (Gold, 2006:221) to create the nation's competitive identities and images based on reality. Based upon the criteria to build a nation-branding model on the sustainable competitiveness (3.1.1), a process-based planning appoach is suitable for this research. In particular, a mechanism-based value-creating process is the optimum model applicable to explaining nation branding as the way to sustain the competitiveness of nations. 


\subsubsection{ADAPTATION: A mechanism-based process approach}

Aiming to define the role of nation branding and create a strategic management tool on nation branding for the sustainable competitiveness of nations, we have developed the key concept of nation branding (2.2.5). In particular, we emphasized a process of nation branding which creates a nation brand as an umbrella brand encompassing from country name through to all the collected activities for national brands, sustains the nation brand system, and ultimately achieves nation brand effects both internally and externally, i.e. sustainable competitiveness of a nation. In line with the research objective, we have addressed that a new model of nation branding needs to adopt a strategic nation branding approach in terms of both strategic management and ongoing process of nation branding that sustains a nation's competitiveness. The conceptualized framework of nation branding as the strategic asset of country management is importantly considered as strategic pillar to investigate the factors and processes sustaining the competitiveness of nations.

Based on the criteria reflecting on both the role of nation branding and sustainable competitiveness of nations, our research has adopted a mechanism-based process approach - combining the strategic planning process with the value-creating process. To develop a model explaining the role of nation branding in sustainable competitiveness, we adapt the approach to building a research model, a Nation-Branding Mechanism Model (Fig. 17). This NB-MM refers to a 'mechanism-based nation branding model' explaining a dynamic sequence of branding behaviours that take place contextually within a nation brand system and that influence the sustainable competitiveness of a nation. In structuring the NationBranding Mechanism Model, this research adopts a framework that integrates an inputprocess-output model for a holistic branding approach and, based upon this, focuses on 'process' in detail.

For the input dimension of nation branding, 'built-in stereotype' (White \& Cundiff, 1978 ) is highlighted. As an intial step in the nation-branding process, an awareness of the stereotype is needed before any attempt is made to consciously create a nation brand (Dinnie, 2008:142). Stereotyping is a mechanism that people will always use to simplify a world rich in meaning, and which has a dynamic and evolving nature rather than a static one (Freire, 2005). In a similar context, Kotler and Gertner (2002) have claimed that a nation brand has a built-in equity that individuals in various target markets develop over their lifetimes.

The process of nation brand management is started with vision creation (Aguirre \& Renjel, 2008; Hankinson, 2007; Hankinson, 2004; Endziņa \& Luņeva, 2004; Yan, 2003; Rainisto, 2003; Frasher et al., 2003). If a nation brand must act as the central organizing principle to achieve a nation's wealth (Clifton, 2004) and as a guide to the strategic decision-making of country management (Gilmore, 2002), a vision of a nation brand firstly needs to be created. A powerful brand vision points to the long-term intent for the brand 
which must enourage the actors' commitments and enable them to interprete how they can contribute to success (De Chernatony, 2001:33).

While vision is characterized in a rather abstract way and needs long-term perspective, a goal is about short-term action directed to achieving vision. The expectations and goals are considered to be the parameters within which any place brand strategy should be developed (Kerr \& Johnson, 2005). The strategy of what to compete for and of where to compete is commonly highlighted as the most important factor influencing performance outcomes in sustainable competitive advantage (Aaker, 1998; Porter, 1998; Day, 1990). A national brand strategy ensures that strategic vision is supported, reinforced and enriched by every act of communication between the country and the rest of the world (Anholt, 2005a:11). For their long-term direction and scope, nations must make strategic decisions about configuring resources and competences to achieve their goals (Dinnie, 2008:220).

The final and self-evidently important stage lies in implementing the chosen strategy, and key challenges in strategy implementation include ensuring control (Dinnie, 2008; Johnson, Scholes \& Whittington, 2005). In line with a nation brand behaviour, branding actors from the national leader through the social system (i.e. stakeholders) have been considered as the fundamental construct in nation branding. Branding actors are typically involved in developing and executing various branding stages (Papadopoulos \& Heslop, 2002:310-11).

For the strategic framework that offers a clear guideline for national development and competitive advantage, the Nation-Branding Mechanism Model integrates them (i.e. from vision creation, goal setting, strategy development and implementation, through to branding actors) into a nation branding process.

Brands are expected to achieve sustenance of competitiveness (Louro \& Cunha, 2001; Porter, 1980; Karakaya \& Stahl, 1989). Therefore, we suggest that the Nation-Branding Mechanism Model (NB-MM) (Fig. 17) is a mechanism-based process model that implies a strategic nation branding approach in terms of both strategic management and ongoing process of nation branding that sustains a nation's competitiveness.

The NB-MM comprises a sequence of branding behaviours (i.e. actors and activities), i.e. creating a nation-brand vision (C-NBV), setting a nation-brand goal (S-NBG), developing a nation-brand strategy (D-NBS), and operating a nation-brand strategy (ONBS). The process is trigerred by market input, and influences the sustainable competitiveness of a nation. 
Fig. 17 A Nation-Branding Mechanism Model (Research Model)

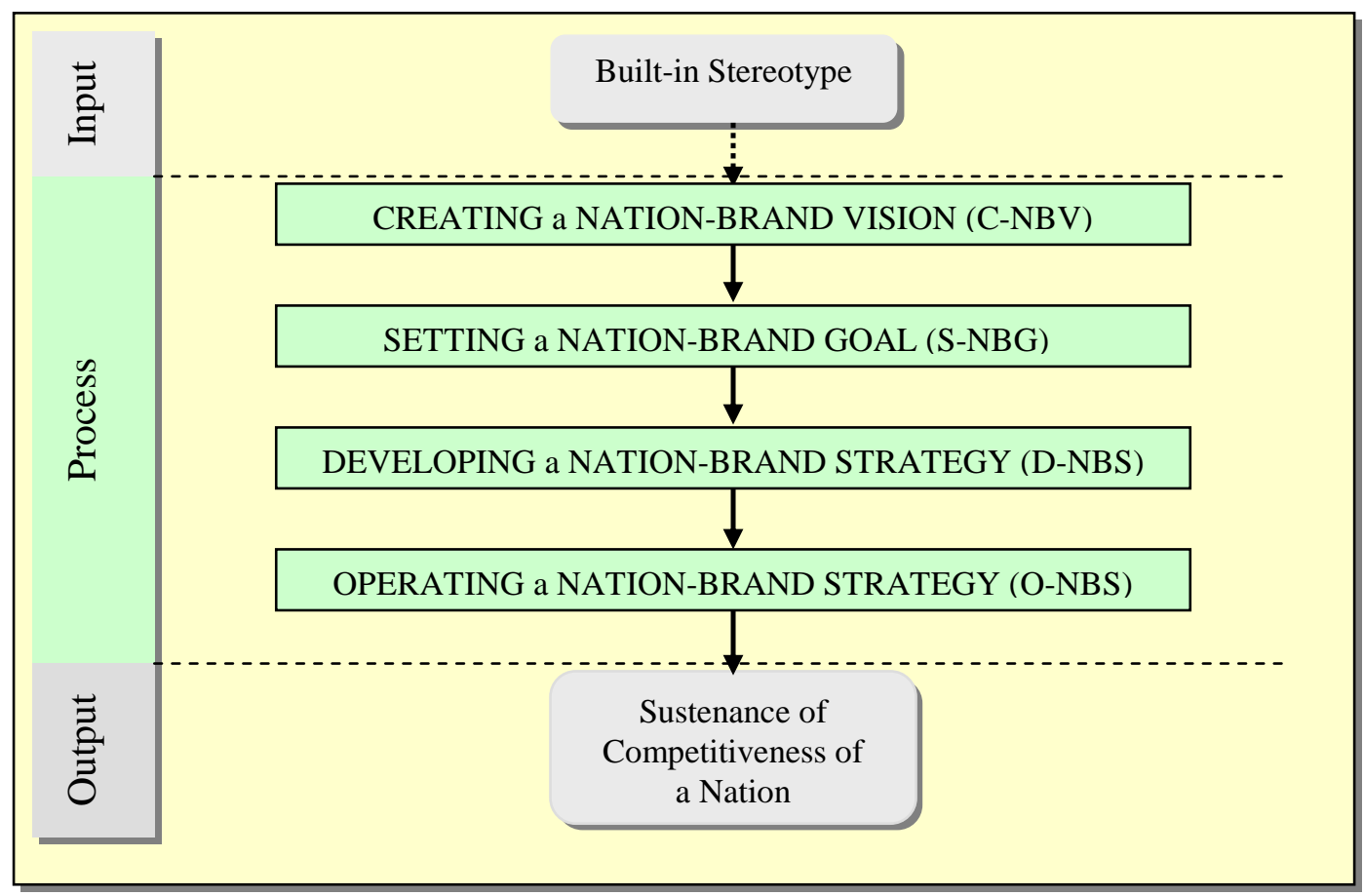

\subsection{A NATION-BRANDING MECHANISM MODEL (NB-MM)}

Focusing on the process of holistic nation branding for sustainable competitiveness, this section elaborates the phases in NB-MM. Each phase elucidates branding behaviours that comprise the contextual parts (i.e. branding actors and activities) related to performance in nation branding. Finally, we construct sustenance of competitiveness as the outcome of nation branding.

\subsubsection{PHASE I. CREATING A NATION-BRAND VISION (C-NBV)}

To correspond to a nation's truths and deliver its promises to national or international communities, the nation brand vision (NBV) needs to be clearly defined. Yan (2003) insists that vision representing a nation brand matches the truths in international relations and community. At all stages of brand development and, in particular, at the beginning of that process, it is important to develop the vision of the brand to allow scope and flexibility for extension across various product categories (Gnoth, 2002:276). Creating the vision is the primary step for the strategic market planning process for place development (Kotler et al., 1993). Successful places have developed their own solutions to have a vision to guide economic development (Rainisto, 2003:30).

Brand vision is described in an internal document that clearly records the future path and growth for the brand, which clearly lays down the future direction for the brand and the 
desired role and status that the brand hopes to achieve in a stated time (De Bono, 2006:102). Vision can be nothing but a dream if there is a very wide gap between the present and the future being represented (Hamel \& Prahalad, 1989). To be an efficient and socially and environmentally responsible nation brand, Gnoth (2002:276) describes that the vision needs to be guided by the type of attractions the country has. Gluck (1984) articulates that brand vision is built on the basis of a deep understanding of the dynamics of industries, markets and competition, and the potential of the organization for influencing and exploiting these dynamics. Some researchers thereby advocate strategic analysis work to create the vision. Researchers (Dinnie, 2008; Anholt, 2007a; Rainisto, 2003; Kotler et al., 1993) have insisted on analyzing a whole picture of what a place has been building internally and externally. In the nation management context, O (1995) primarily emphasizes 'the principles' that a nation has set "for the people". In order to strategically manage a nation, therefore, brand vision is ultimately established on the basis of the national vision that is envisaged by those principles (Ibid).

Vision creation relates to the nation leader and leadership as an ability with qualities to be a leader (Hankinson, 2007; 2004; Rainisto, 2003; Kotler et al., 1993; Gluck, 1984). The leader of a nation takes the main role for building the nation brand and managing it with expert support (Anholt, 2003). To achieve sustainable brand value, nations sometimes need heroes. Cho (1997:16-20) insists that the study of heroes is the starting point to understanding the environment-creating mechanism, and that heroes must possess a futureforward and optimistic spirit, as well as qualities such as creative insight, talent, charismatic and tolerance, pure motivation and fidelity. In particular, Johnson and Scholes (1999) articulate that vision is thought of as related to intuition, and highlight that the outcome of the intuition is a vision associated with the command of a leader or a process of political influence. As well as a nation leader, the government has the main responsibility to create vision (Anholt, 2007a; Rainisto, 2003). Meanwhile, Gnoth (2002:277) articulates that brand development is more likely to succeed by being managed 'bottom up' rather than 'top down', developing a brand community that creates communication and interaction patterns. From the perspective of organizational change theory, moreover, Beer (2001) points out that the effective behavioural approach for high performance is to apply both top-down, results-driven change and slower, bottom-up development of the organization. The top-down approach typically leads to immediate improved financial performance; organizational capabilities through bottom-up approach, arising from the social system (i.e. groups of people), result in sustained high performance and economic value (Ibid).

Nation brand vision is a strategic vision representing a core value and ideology of a nation. A strategic vision is created as part of the planning process in an organization, or has become embedded in the history and culture of the organization (Johnson \& Scholes, 1999:68). Strategic vision requires a will to change, and the expectation of paradigm shifts (Aaker, 1998). In achieving sustainable competitiveness, Cho (1997) insists that vision is attributed to three specific characteristics: first, vision must present 'a wanted future' to the 
people; second, vision must be innovative beyond the extent of current competitive competence; third, vision must match the shared understanding of the people. A nation brand's core value is composed of the spirit of the people of the country and their shared vision influences brand positioning and stakeholders (Gilmore, 2002:285-90). Vision must inspire the organization to be creatively ambitious and motivate the people to work hard to help realize the vision (Filion, 1991). Vision, according to Day (1990:15-18), is a guiding theme that articulates the nature of the business and its intentions for the future, which is defined in terms of four types of strategic vision that guides successful business (Table 31).

Table 31 Types of strategic vision

\begin{abstract}
-Informed Vision: A vision must be grounded in a solid understanding of the business, and the ability to foresee how the forces operating in the market will change the future. Here vision is equated with insight. -Shared Vision: Visions will motivate organizations when they are created through collaboration, with the leader serving as the articulator and sponsor of the vision that emerges from the team's collaboration. -Competitive Vision: Powerful visions are also statements of intent that create an obsession with winning throughout the organization. By focusing attention on a desired leadership position, measuring progress against that achievement, and continually searching for new ways to gain competitive advantage, the actions and ideals of the organization are given meaning.

-Enabling Vision: Visions flourish within organizations where individual managers have enough latitude to make meaningful decisions about strategies and tactics. These individuals are empowered to use the general framework articulated by the vision to decide which opportunities or threats to respond to.
\end{abstract}

(Source: Adapted from Day, 1990: 15-18)

The clearer a vision is, the more it is competitive in an internationalization process (Allali, 2006). In order to represent the core value and ideology of a nation, the study claims that creating a nation-brand vision needs branding activities and actors who comprehend strategic analysis, national vision development, a top-down or bottom-up approach, and notions of strategic vision.

Phase I. Creating a Nation-Brand Vision (C-NBV)

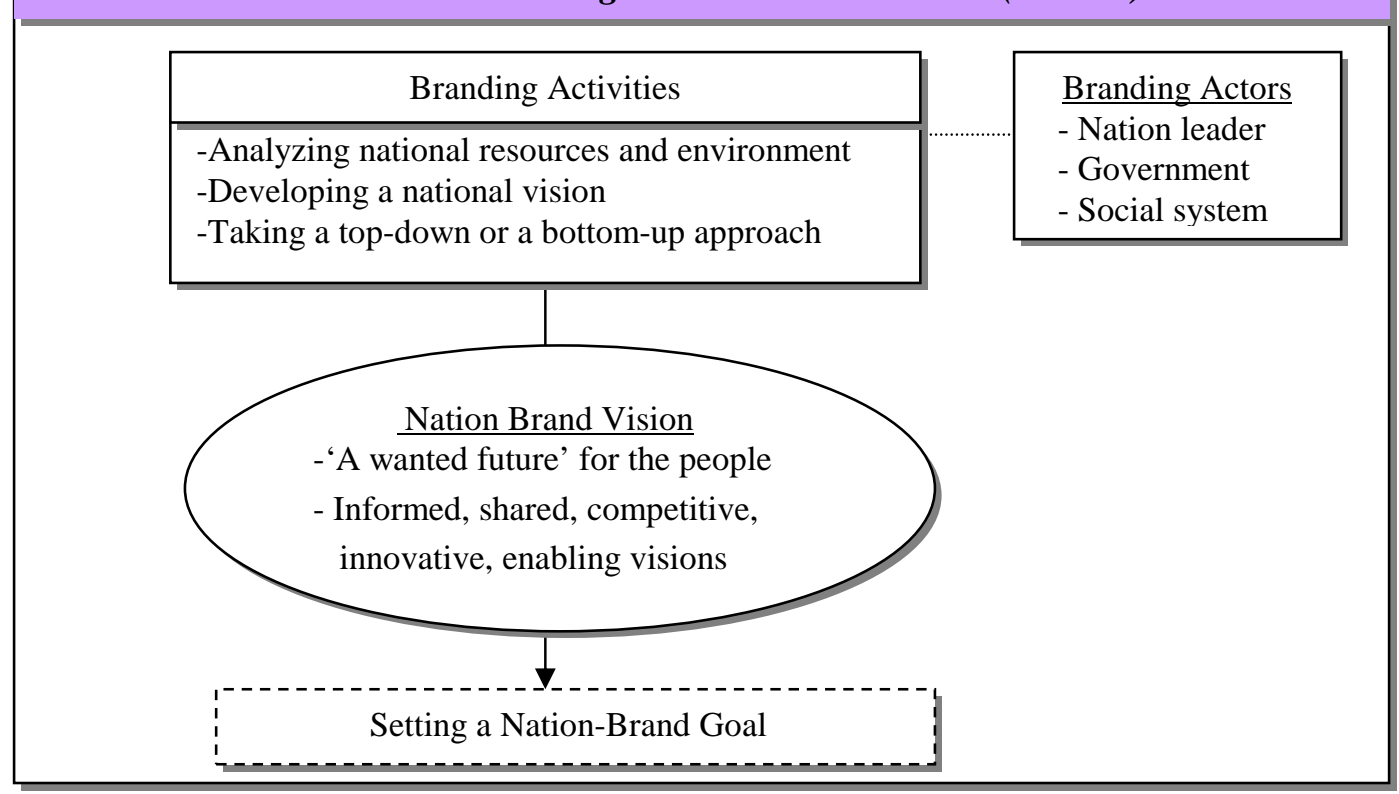




\subsubsection{PHASE II. SETTING A NATION-BRAND GOAL (S-NBG)}

The goal in the environment-creating organization is set in a different way in the environment-adapting organization (Cho, 1997). While the latter sets the goals by using internal resources in order to adapt to environmental change, the environment-creating organization sets the strategic goal on the basis of vision and aims to create a new environment (Ibid). In establishing objectives and goals, strategic analysis is referred to as the key branding activity. Strategic analysis is about understanding the strategic position of the organization in terms of its external environment, internal resources and competences, and the expectations and influences of stakeholders (Johnson \& Scholes, 1999:17). Strategic analysis, both internally and externally, is necessary for nation branding (Dinnie, 2008; Kerr \& Johnson, 2005; Rainisto, 2003). For strategic place branding, it requires an understanding of the strengths and weaknesses of the country to compete with others and entails a dynamic understanding of the opportunities and threats. The purpose of the brand audit is to provide an overall analysis of the brand from internal and external sources, and to identify both the brand differentiators and basic brand attributes on which the brand can be built (De Bono, 2006:96). In nation branding, researchers (Gilmore, 2002; Kotler \& Gertner, 2002) have emphasized the need to analyse internal resources and external markets related to the nation brand.

Once a vision has been developed, the stakeholders in a place need to set specific objectives and goals (Kotler et al., 1993:94). Vietor (2007) claims that national goals for national economic development consist of loose generalities, such as "economic growth" or "political stability" and can be identified more precisely in an objective statement. Objectives are only directional statements, and they must be turned into goals to make them measurable and motivating to those who are responsible for planning (Kotler et al., 1993:94). Goals provide clear direction as to a place's economic development towards expected achievement, and become the basis of earmarking the resources needed to accomplish them (Ibid). In line with the temporal scope, goals also can be expressed as medium- or long-term dimensions (Leonard et al., 2005).

Fig. 18 Obejctive and goal statements

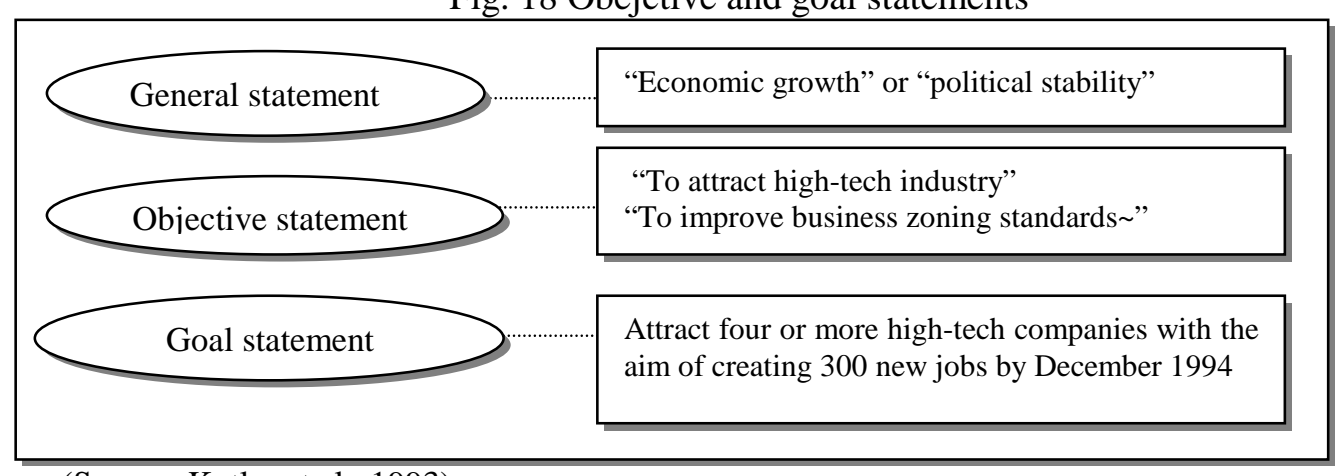

(Source: Kotler et al., 1993) 
In the context of place development and marketing, a planning group has been mainly considered as a branding actor (Rainisto, 2003; Kotler et al., 1993). The economic planners determine the target goals, based on forecasts of the future changes that might influence the trade and growth of the country (Levary \& Choi, 1983:1057). In particular, an economic development professional focuses largely on helping a place improve its competitiveness, through analyzing a place's strengths and weaknesses, opportunities and threats as they are affected by external forces, and also determining how the local economy best fits into a changing regional, national and global context (Kotler et al., 1993:75).

Based on the notions, this study assumes that the nation brand goal primarily reflects a nation's brand vision and needs to analyze internal resources and the external environment related to the nation brand, so directing how to develop a strategy for nation branding.

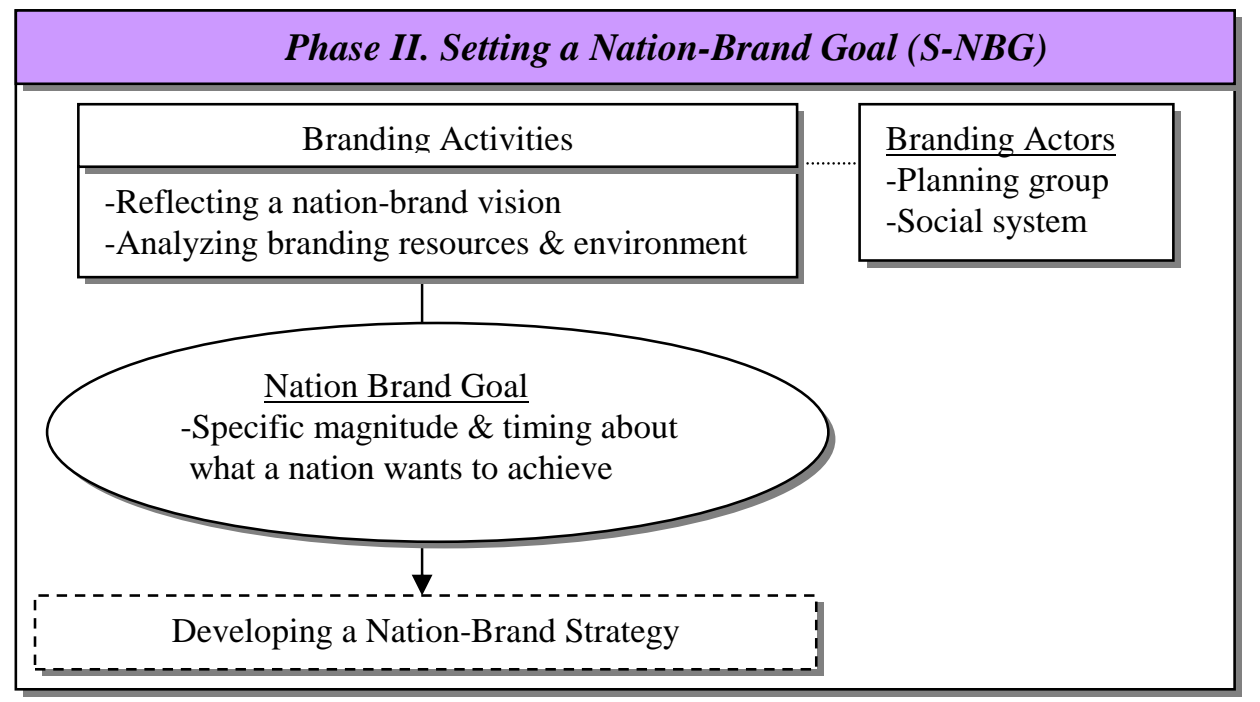

\subsubsection{PHASE III. DEVELOPING A NATION-BRAND STRATEGY (D-NBS)}

Researchers in nation branding have emphasized the imperatives of creating a nation brand strategy (NBS). Anholt (2004: 9) highlights, for instance, the real value of NBS which best suits the country's aims and visions. Gilmore (2002:285) strongly proposes that NBS provides a guide to the strategic decision for a national strategy. Nation branding, as O'Donovan (2004) asserts, is the practice of applying a brand strategy to the economic, social, political and cultural development of a country. Therefore, nation brand strategy needs to fit to a nation's branding vision and goal. Developing a nation brand strategy relates to developing national strategy encompassing the economic, social, political and cultural development of the country.

In general, a strategy is a directional statement encompassing both an explanation of the pattern of past actions and a guide to future initiatives and programs (Day, 1990:21), or the direction and scope of an organization over the long term (Johnson \& Scholes, 1999:10). In a strategic management process, strategic choice provides meaning and 
direction to the myriad activities of the business in shaping expectations for profit and growth performance (Day, 1990:14). Strategic choice involves understanding fundamental factors guiding future strategy (i.e. identifying the bases of competitive advantage arising from an understanding of both markets and customers, and special competences), forming strategic directions, and selecting from among them (Johnson \& Scholes, 1999:20).

Dealing with what makes the brand unique, inspiring, believable and trustworthy (Van Gelder, 2005), brand strategy has been referred to as the intended direction linked to organizational strategy (De Bono, 2006:99). To improve their competitive positions, places have been developing strategies of attracting and retaining enterprises to help enterprise development (Kotler et al., 1993). That is, promoting foreign trade and investment has emerged as an important place development strategy (Ibid: 285). To help nations or places achieve their strategic objectives, a promotion strategy in line with their overall development strategies has been particularly highlighted (UNCTAD, 2002; Kolter et al., 1993). Therefore, developing a nation brand strategy (D-NBS) relates to the identification of the bases of the overall national strategy or national development strategy on competitiveness and to guide future initiatives for national strategic directions. In particular, the promotion strategy in line with the branding strategy envisages how a nation can achieve national development through serving its target markets.

In the context of competitive advantage, Vietor (2007) claims that every country must make choices when developing resources efficiently. Whether or not a place adopts a strategic market planning approach for place competition, careful attention to these features and attributes can create the foundations of a place strategy (Kotler et al., 1993:100). Lenway and Murtha (1994) assert that a government's strategic capability relates to the formulation of government plans to allocate resources with the intention of meeting longterm national economic objectives, including growth and international competitiveness. As pointed out in the description of the value-creating process model (Cho, 2006), restructuring an environment and resources is also an important aspect to consider if an organization is to remain competitive.

The availability of resources determines the overall branding strategy (De Bono, 2006). Good strategies consider responses to market conditions and internal strengths and weaknesses (Adcock, 2000). Furthermore, they anticipate problems in a competitive context (Ibid). In the strategic brand management process, it is necessary to develop brand positioning ${ }^{4}$ by clarifying the brand's essence in a unique way (Kotler \& Keller, 2006:309). The initial choice of brand attributes is crucial, since it determines competitivenss (Kotler \& Keller, 2006; Gnoth, 2002). The brand identity strategy is a framework for identity building (Upshaw, 1995). It is about being honest about what assets and liabilities a brand carries with it, and about looking for every opportunity to capitalize on a brand's strengths

\footnotetext{
${ }^{4}$ Positioning is the act of designing organization's offering and image to occupy minds of consumers to maximize the potential benefit to the organization (Kotler \& Keller, 2006:309).
} 
(Ibid). Ries and Trout (1982) argue that a competitive frame of reference for brand positioning is to decide product category membership (the products or sets of products with which a brand competes) and to decide on a target market.

Considering on how a nation's identity can become more competitive, Anholt (2007a: 34) asserts that competitive identity depends firstly on having a proper competitive strategy for the country. That is, in creating a culture of innovation in every sector (i.e. government, culture, tourism, business, investment promotion, education, industry), the country starts to produce a constant stream of new ideas and then a communication strategy becomes necessary (Ibid). To direct strategic choices for nation branding, therefore, a government's plan - which needs to depict a nation brand strategy, encompassing how to allocate resources and how to communicate to target markets - is about the intended direction and scope that links to national strategy or national development strategy. That is, how to build competitive identities, i.e. innovative brand attractions or product categories, and how to communicate with selected target markets are important notions to be considered in selecting a nation brand strategy.

Leadership means the holistic capability of the place management to conduct the complex process, to form the right strategies and to obtain the organizational power, which enables the taking of a successful market position (Rainisto, 2003:84). According to Gluck (1984), leadership is essential not only to create and refine the vision but also to follow a successful process in deploying the resources in pursuit of a new vision, building the capability with the experience, judgment and intuitive commitment to their vision, changing the perceptions and behavior of external initiatives (i.e. external stakeholders and consumers), and removing internal obstacles to change. A leadership style must be distinctive for a nation to be differentiated (Sousa, 2000). Although the precise nature of the leadership role can vary, it is important for leaders to assign responsibility to individuals and groups (Hardy, 1994:131).

Andrews (1980) insists that the essence of defining strategy is pattern. That is, it is important to uphold the coherence and internal consistency of an organization's strategic decisions that position the organization in its environment and give the organization its identity, its power to mobilize its strengths, and its likelihood of success in the market place (Ibid). Therefore, nation brand strategy needs a balanced approach between internal and external focus and a coherent approach from short to long-term planning. To develop a nation brand strategy, it is necessary to have branding activities reflecting a nation brand goal (NBG), developing national strategy or development strategy, and crafting brand positioning with branding actors, which enables advancement to the implementation stage. 


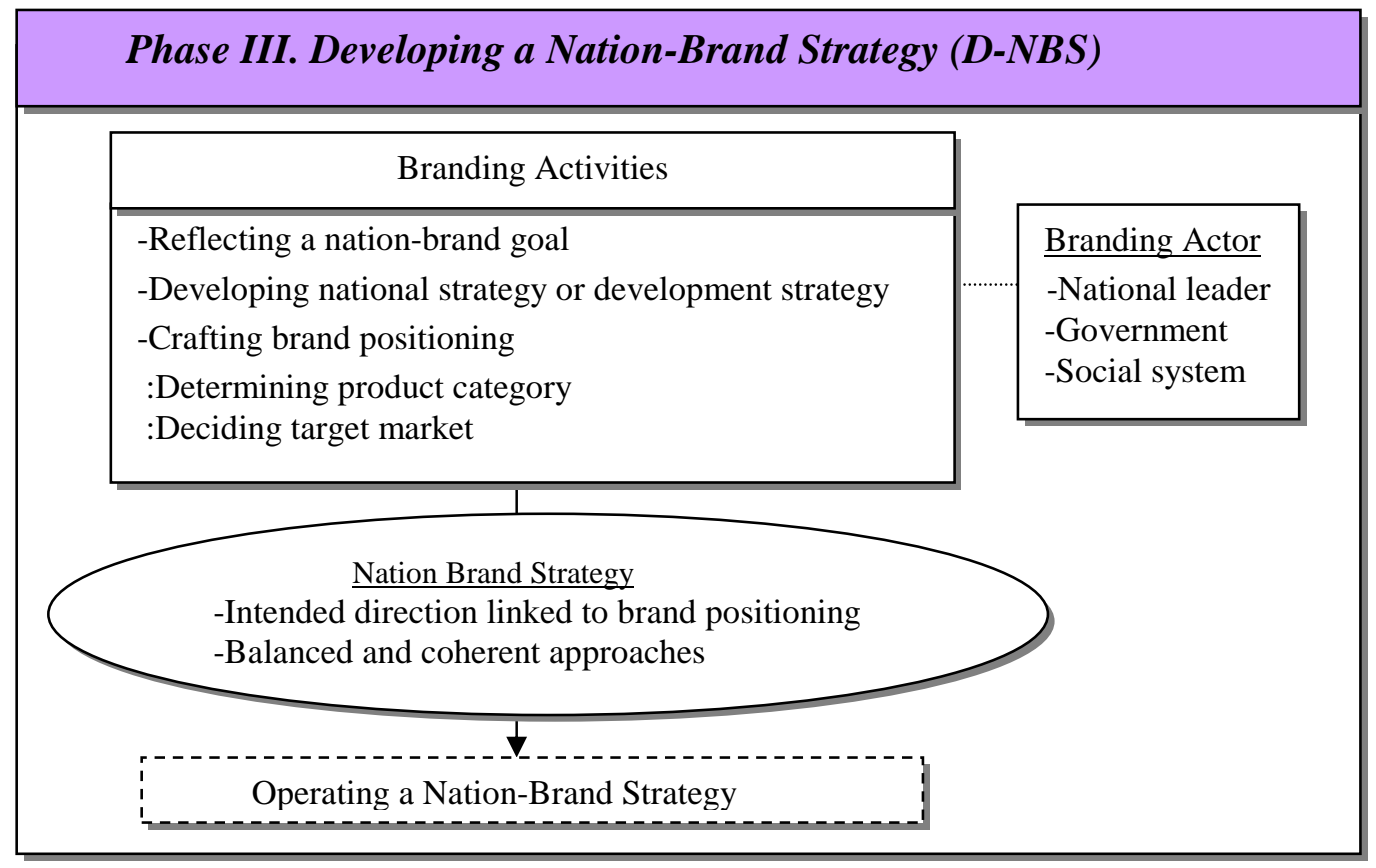

\subsubsection{PHASE IV. OPERATING A NATION-BRAND STRATEGY (O-NBS)}

The brand implementation phase is where all the planned strategies are put into practice in the marketplace, and where brand associations eventually start to form in the mindset of customers (De Bono, 2006:112). Strategy implementation is concerned with translating strategy into organizational action and comprises a series of subactivities (Johnson \& Scholes, 1999; Hardy, 1994). Successful implementation of a strategy is likely to be dependent on the extent to which the various implementation units are effectively integrated to deliver competences (Johnson \& Scholes, 1999:22).

Countries vary in their capabilities to implement new economic strategies (Lenway \& Murtha, 1994). To improve the organizational or institutional operations, operating tools are articulated. Beauchamp (2001) asserts that visions can never be realized without clear actions, and a critical step in realizing the leader's vision is for the leader to support words with actions through policies and programs. A repertoire of policies or practices that constitute organizational or institutional capabilities has been highlighted throughout international business (Buckley \& Ghauri, 2004) or organizational performance (Orlikowski, 2002; Luthans \& Stewart, 1977). Nation branding needs to coordinate a nation's entire socio-economic policy (Macrae, 2008:246). Policy drives activity that impacts on how our places look and feel, how we engage with them, what benefits they offer us and how we perceive them (Parkerson, 2007). In particular, Bacon and Pugh (2003) insist on the organization's policies and standard operating procedures for interacting with audiences and internal resources and differentiating an organization from its competitors. Government policy influences the business environment to support rising productivity (Porter, 1998). Specific industrial policies serve to promote the international 
competitiveness of targeted manufacturing industries and, through the linkage of international markets, play a significant role in defining a nation's competitive advantage (Audretsch, 1997). To implement the strategy, those policies or programmes developed actually reflect the strategic options chosen (Adcock, 2000).

Implementation involves resource planning (Johnson \& Scholes, 1999). Resources should be deployed and upgraded in the most productive ways possible (Porter, 1998). That is, through resource configuration within a changing environment, strategy achieves advantage for the organization (Johnson \& Scholes, 1999:10). In the branding context, resource planning relates to a way of identifying the level of brand identity and developing it. Brand identity is the essential contributor to the nation branding perspective. In particular, it is important to clarify the core brand identity (Florek, 2005; Joachimsthaler \& Aaker, 1997). In building nation brand identity, the attraction what a nation has provides emotional power, and the choice of attractive elements helps determine and shape competitiveness (Gnoth, 2002:270). Place branding combines a place with unique attraction factors to make it different from the competing places (Rainisto, 2004:14). Therefore, identifying brand identity is essential to defining the brand attraction of a nation. According to Murtha and Lenway (1994), a policy that focuses on a specific target (e.g. industry) enables a country to increase its capabilities. In deciding on overall image promotion policies, policy makers can start by selecting their country's key industries and then the major brands within each industry (Jaffe \& Nebenzahl, 2006:68).

A place's image is a critical determinant of the way that citizens and businesses respond to the place (Kotler et al., 1993:141). Images represent a simplification of many associations and pieces of information connected with the place. To implement an effective image building of a place, designing, communicating and delivering a place's image are important within strategic image management (Ibid). A brand communication is to share an experience between the sender or source of the message and the recipient of that message (Hankinson \& Coowking, 1996:106). It is most important to identify and develop a nation's identity and, furthermore, to communicate the parts of the identity that are favourable to specified target groups. Strategic vision is supported, reinforced and enriched by every act of communication between the country and the rest of the world (Anholt, 1998). For the identity to work, it must be conveyed through every available communication mix (Table 32) and brand contact (Kotler \& Keller, 2006:320) using integrated image-building techniques (Wells \& Wint, 2000). 
Table 32 The elements of communication mix

-Advertising: has perhaps responded fastest to the globalization of the market function
-Global sponsorship: focuses around two key events, the Football World Cup and the Olympic Games
-Public relations: aims to create a favourable reputation for the brand by influencing and coordinating
different groups of people and different channels of communication
-Packaging: is regarded as a continuous communication of the brand. Communicating a consistent brand
proposition through packaging has led to harmonize or standardize pack designs across borders
-Sales promotion: is perhaps the most hard-nosed in its objective of converting an intent to buy to a sale
-Direct marketing: is increasingly used to reach highly targeted segments of the international population
on a personal, one-to-one basis. The aim of a direct marketing campaign is to establish and maintain a
continuing relationship with a customer

(Source: Adapted from Hankinson \& Coowking, 1996; Kotler et al., 1993)

The important point of the implementation stage is who has overall responsibility for the implementation programme (Johnson \& Scholes, 1999; Hankinson \& Coowking, 1996). It is in the area of implementation that nation branding faces its biggest challenge, given that a nation brand's stakeholders may not be well structured (Dinnie, 2008:224). A set of national institutions (i.e. national government, local governments or quasigovernmental agencies) have initiated and developed nation branding with their stakeholders in order to achieve the common purpose and brand vision. Anholt (2007a:82) strongly urges that unless the government can find a way of achieving a common singleminded sense of purpose and control, nothing will come of the competitive identity project. Aiming for the competitiveness and prosperity of nations, an activist role - e.g. ensuring vigorous competition, providing high-quality education and training - by government provides for the creation of a business environment that supports rising productivity (Porter, 1998). The market performance of the promotion agency highly influences the location decision of the target market (Kotler \& Gertner, 2002). In particular, public and private partnerships have been emphasized in order to achieve a successful organizational or institutional performance. Without the cooperation and support of all parties, it is unlikely that one sector - government or business acting alone - will be particularly successful over the long-term in turning around a place's economy or in making it more competitive (Kotler et al., 1993:331-338). Coordination and collaboration among institutions and organizations are mainly related to successful nation branding (Dzenovska, 2005; Florek, 2005; Endziņa \& Luñeva, 2004).

A government's implementation capability largely rests on the specificity and credibility of its economic policy instruments (Lenway \& Murtha, 1994). Policy credibility and target specificity work together to determine implementation capability of a nation's industrial strategy (Ibid). With respect to nation branding, the capability in brand operation is emphasized through consistency of operation in policy. One of the fundamental tenets of branding is to achieve consistency of policy (Risen, 2005). Nation branding means consistent policies that "live the brand" (Anholt, 2007a). Keller (2003) stresses the 
cohesiveness of brand elements, i.e. the extent to which brand elements are consistent in representing brand identity. Consistent brand elements reinforce each other and help to unify the core values for creating a nation brand identity and image building process.

Operating a nation-brand strategy (NBS), based on government policy, is about branding activities identifying and developing brand identites and communicating these to target markets. Coordination and collaboration between branding actors are important elements in operating NBS.

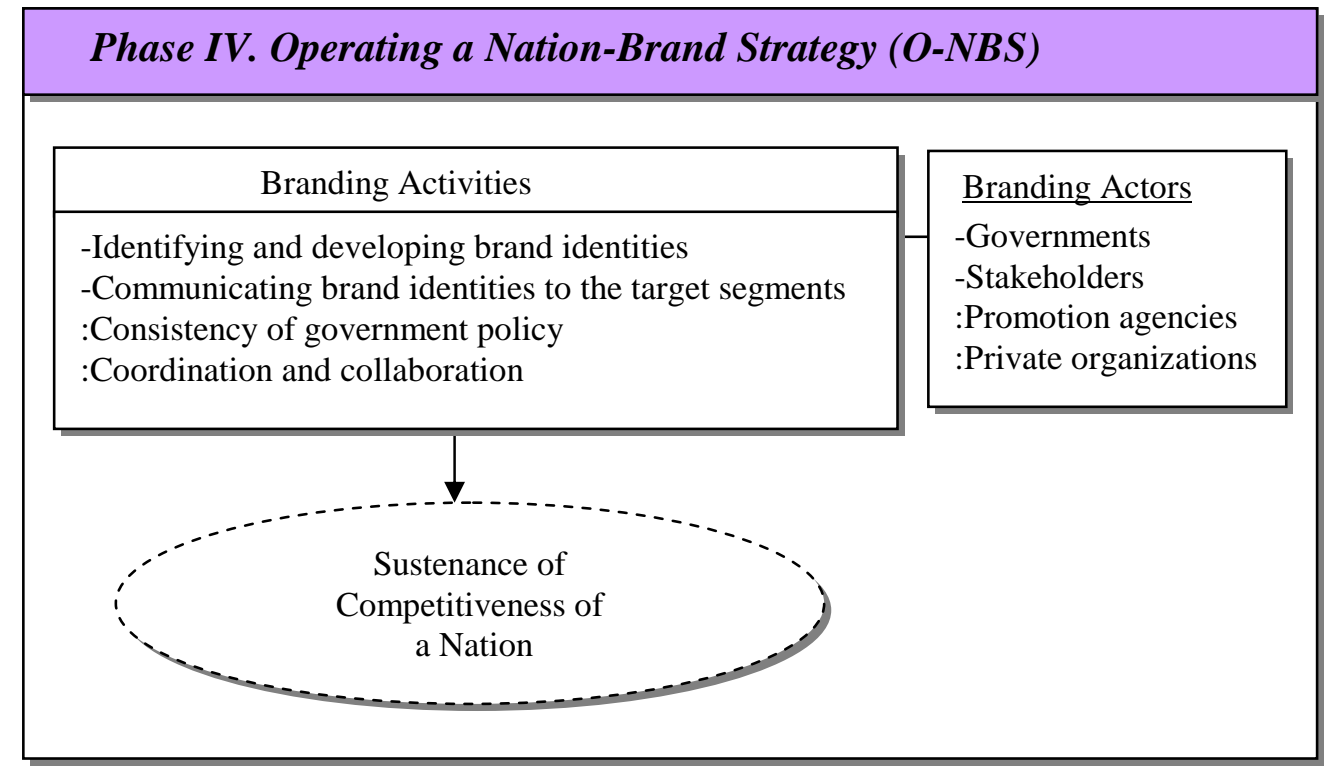

\subsubsection{SUSTENANCE OF COMPETITIVENESS OF A NATION}

Competitiveness is the key driver of the economic success of a country, relying on international business of companies on the one hand and embodying a holistic approach in a country's ability to sustain national economic and social development level for its people on the other hand. In terms of international business, export performance and competitiveness are directly related to the rate of economic growth (UNCTAD, 2002; Levary \& Choi, 1983). FDI stock and flows indicate that locational competitiveness helps to attract and retain foreign direct investment (FDI), which can be referred to as FDI competitiveness. In line with the concept of sustainability, development has been highlighted as being about much more than economic growth and economic development (UNCTAD, 1999). Particularly when dealing with development, the United Nations defines "sustainable human development" that encompasses economic, social, political, environmental and other dimensions, and classifies high, medium and low-levels of country achievements in different areas of human development by a standard means that measures sustainable well-being quality. Francis (1992:66) claims that because this is a relative quality and the data are contentious, it is hard to measure competitiveness. Neverthless, Sachs (1992) states that the goals of development vary, and argues that there are many ways of reaching such goals. Thereby, national goals encompassing economic 
and social development in line with sustainable human value are imperatives in measuring the sustainable competitiveness of nations.

Nation branding is the process to establish "nation brand value (NBV), the totality of nation brand equity (NBE).' Building brand equity provides the organization with a competitive advantage (Farquhar, 1990). There is no agreed single measure of brand equity (De Bono, 2006; De Chernatony et al., 1998; Feldwick, 1996). However, brand equity has been concretized in terms of brand strength and brand perception. Park and Srinivasan (1994) divided brand equity into attribute-based and non-attribute-based components. Brand associations related to product attributes is about the former, while the non-attributebased component of brand equity is created by brand associations unrelated to product attributes (Ibid). Quelch and Harding (1996:39) referred to brand equity as the added value that a brand name brings to the underlying product. Country image is an essential part of nation brand equity (Jaffe \& Nebenzahl, 2006; Van Ham, 2004). In line with social psychology, while attribute-based brand equity is brand strength, non-attribute-based brand equity or nation image has been referred to as brand perception. Brand knowledge constitutes a perceived equity (De Bono, 2006; Trappey III \& Woodside, 2005), being referred to as brand awareness (if and when the audience knows the brand). With respect to knowledge context, reputation has been highlighted as a more advanced level rather than associations. Research has defined reputation as a snapshot that reconciles the multiple images of an organization. Clearly, in today's environment, a country - just like a corporation or other large entity - has to manage its reputation actively if it wants to gain competitive advantage (Anholt, 2007a; Loo \& Davies, 2006). While brand knowledge or reputation represent cognitive information processing, brand preference refers to the level of liking toward a brand and it can range from mere liking to a deep loyalty with repeat actions over time (De Bono, 2006). The loyalty stage comes when customers have deep and meaningful relationships with the brand (Ibid).

Superimposed upon the notions, sustainable competitiveness of a nation is measured in terms of a nation's economic performance and social development achievement. Particularly with respect to the sustainability notion, the human development value of a nation reflects a sustainable well-being quality that encompasses a holistic national development level. Meanwhile, a nation has a large variety of national brands and outputs on the basis of 'product lines' (e.g. tourism, export, FDI). Therefore, nation branding is performed through various project-based ${ }^{5}$ exercises (Clifton, 2004; Lodge, 2002) to attract tourists and business interests or to export products and services. Success in branding is always contextual and is based on the achievement of a project's goal and outcomes per domain $^{6}$ (Rainisto, 2003). Nation brand equity based on product attributes and perception is

\footnotetext{
${ }^{5}$ Rainisto (2003:40) emphases, citing Bennett (1995: 227), that a project is often part of a larger unit of work or a programme that delivers a stream of new products.

${ }^{6}$ Domain is the scope of the area in which success is assessed, and the domains can overlap each other (Rainisto, 2003:40).
} 
an important dimension to be measured. From the inclusive approach, brand equity must be interpreted based on total value delivered, not attempting to subtract anything (Abela, 2003; Barwise, 1993). Highlighting the inclusive approach to measuring brand value and equity, this research extends it to measure the sustenance of competitiveness of a nation (Table 33). We focus on three aspects as effective performance outcomes in nation branding: national development goal; project-based goal; and nation brand equity.

Table 33 Sustenance of Competitiveness of a Nation

\begin{tabular}{|c|l|l|}
\hline $\begin{array}{c}\text { National } \\
\text { Development } \\
\text { Goal }\end{array}$ & \multicolumn{2}{|l|}{ Economic and Social Development } \\
\cline { 2 - 3 } $\begin{array}{c}\text { Project-based } \\
\text { Goal }\end{array}$ & $\begin{array}{c}\text { Product line-based } \\
\text { Competitiveness }\end{array}$ & Export, FDI, Tourism \\
\hline \multirow{2}{*}{$\begin{array}{c}\text { Nation Brand } \\
\text { Equity }\end{array}$} & $\begin{array}{c}\text { Product attribute-based } \\
\text { Equity }\end{array}$ & Product attributes \\
\cline { 2 - 3 } & Perception-based Equity & $\begin{array}{l}\text {-Brand knoweldge (awareness) } \\
\text {-Brand reputation } \\
\text {-Brand preference } \\
\text {-Brand loyalty }\end{array}$ \\
\hline
\end{tabular}

\subsection{CONCLUSION}

To define the effective performance in nation branding with respect to sustainable competitiveness of nations, we addressed the need to develop a nation-branding model based on a strategic nation branding approach. In this chapter, the criteria were selected for nation branding and sustainable competitiveness contexts. A mechanism-based process approach was adopted for model building and adapted to construct the new research model of nation branding.

In developing a nation-branding model to explain the role of nation branding that contributes to the sustainable competitiveness of nations, the first criterion needs to fit to the sustainable competitiveness context. Successful nation branding is achieved by assuming a nation's competitiveness in the global market environment. Therefore, a model should be suitable to not only explain an interconnected process of creating competitive resources and simultaneously corresponding to the global market environment, but also to address the dynamics of integrating a sequence of input, process encompassing the sources of competitive advantage, and performance outcome.

Nation branding - as a scientific concept of creating the sustainable competitiveness of nations - ultimately aims to achieve country value and to manage a nation's brand equity. Strategic management of nation brand equity relates critically to developing a sustainable brand system and managing that system holistically. A model should be suitable to align the nation brand with the nation's strategy and direction for sustainable development. Also, nation branding involves managing a nation's identity and image as a 
critical part of nation brand equity. To manage the identity and image, it is important to build a model that is suitable for dealing with creating the brand's uniqueness or attraction based on the reality of a country and which reflects the dynamic phenomenon of changes of the nation's reality, both internally and externally driven. Most of all, a sustainable brand system is managed by the country's behaviour, encompassing branding actors and their activities, i.e. nation brand behaviour. Thereby, it is important to address nation brand behaviour, i.e. branding actors and their activities, within an effective nation-branding model.

For developing a model that explains the role of nation branding with respect to sustainable competitiveness of nations, this research reflects on how the strategic planning process can lead to a successful place development and how value-creating processes can drive an organization's sustainable competitiveness. Based on existing mechanism-based process models, the Nation-Branding Mechanism Model (NB-MM) is introduced as a 'mechanism-based nation branding model' to explain a sequence of brand behaviours that contextually take place within a nation-brand system and that influence the sustainable competitiveness as performance outcome of nation branding. 


\section{CHAPTER 4 DEVELOPING THE RESEARCH PROTOCOL}

A research protocol is an effective way of establishing the reliability of empirical testing and increasing construct validity (Yin, 2003). In this chapter, a developed research protocol applicable to the collection of data for empirical evidence and to the analysis of the collected data is provided. Such a protocol is more than an instrument and contains procedures to be followed in using the instrument (Yin, 2003:67). Therefore, this chapter comprises sections of motivating the choice of a case study as the data collection method (section 4.1), case selection (section 4.2), selected cases (section 4.3), and the selected case study protocol (section 4.4).

\subsection{CASE STUDY}

Data are collected from a variety of sources and are then assembled in a single document with the sources of these data listed, together with an explanation of the methods used in collecting the data (Saunders et al., 2007). In collecting the data in the field, authors point to several tatics. Cooper and Schindler (2003) articulate that it is important to decide on the data collecting scale that is ranged from a simple observation at one location to a wide-ranging survey in different parts of the world. Data collecting scale relates to the choice between breadth and depth. According to Verschuren and Doorewaard (1999), the notion of breadth follows a large-scale approach which enables a generalization of the results, but which imposes limits on depth, elaboration, complexity and a sound foundation of the results. If the study aims for a small-scale approach, this will yield knowledge that can be generalized to a lesser extent. However, this latter approach in depth enables us to achieve depth, elaboration, complexity and a sound foundation with a minimum of uncertainty (Ibid: 144).

The method of breadth and depth research is related to qualitative or quantitative research. According to Eisenhardt (1989:538), qualitative data are useful for understanding the reason or theory underlying relationships revealed in the quantitative data. Bauer et al. (2005) refer to quantitative research as 'hard' research that deals with numbers using statistical models to explain the data and to qualitative research as 'soft' research that deals with 'interpreting' social realities. Significantly, there should neither be quantification without qualification nor should there be statistical analysis without interpretation (Ibid). The qualitative information gathered from researching management processes helps to explain the reasons for success (Buckley, Pass \& Prescott, 1988:178).

In conducting longitudinal field research on organizational processes, a different set of methodological issues are involved (Van de Ven \& Huber, 1990:215). According to Yin (2003), using a case study method remains one of the most challenging methods in the social sciences. The research itself focuses on a particular domain of activity, and 
qualitative research methodology is often described as a case study approach (Piore, 2006:17). Case studies as used in the social sciences tend to be viewed as offering empirical results (Ibid). In particular, case studies are useful ways to explain the use of process research models (Newman \& Robey, 1992:256).

A case study methodology is relevant to collecting nation-branding data. Nation branding aims to discover identities or attractions about the nation and to manage them along with image or reputation. Moreover, nation branding is an umbrella concept encompassing all sub-brands in different product lines and integrating various images into a unified branding idea, which connotes the nature of complexity or uncertainty in a nation branding process. Given the link to the breadth or depth approaches, a case study enables us to gain depth, elaboration, complexity and a sound foundation for nation branding study. "No effective branding decision can be made without sophisticated qualitative research [...]. Usually brand-orientated research starts with qualitative techniques [...]" (Lindsay, 2004:9). We are increasingly asked for case histories, and take these as indicators to learn from other's experience, to gain insights into the challenges to which a place must respond and to help shape what kinds of brand a country should adopt (Lodge, 2006). Therefore,

- In terms of the nature of complexity and uncertainty of nation branding, a case study providing a qualitative and in-dept knowledge is a suitable method to collect data for explaining performance in nation branding.

We, in the preceding chapter, have developed a 'Nation-Branding Mechanism Model (NB-MM)' as a research model. The NB-MM refers to 'a mechanism-based process model' that explains a sequence of branding behaviours (i.e. branding actors and branding activities) that contextually take place within a nation brand system and that influence the sustainable competitiveness of nations. The case study approach focuses on understanding the dynamics that are present within single settings (Eisenhardt, 1989:534). It is a useful way to explain the use of a process research model (Newman \& Robey, 1992:256). In line with a mechanism-based view, Cho (2006:110) insists that a case study enables us to find out contextual phenomena arising from a management process, to carry out an in-depth analysis between the contexts, and to take a holistic view of the process. In particular, the case study is applicable either to test or to generate a theory (Cho, 2006; Eisenhardt, 1989). Therefore, it is concluded that:

- A case study is an appropriate approach to finding out contextual phenomena throughout the branding process, to analyzing the contexts, and to obtaining an holistic view of nation branding process

- A case study is an applicable method to test a provisional model and then to develop a revised model that explains performance in nation branding.

The Nation-Branding Mechanism Model (NB-MM) is designed to be a model explaining "how and why nations achieve the sustainable competitiveness through nation 
branding", and providing "the branding story based on temporal sequence by recounting how nations create competitive identity and image." A case study method is suitable to generate answers to 'why?', 'what?' and 'how?' questions (Saunders et al., 2007; Yin, 2003). Moreover, researchers have applied case studies to test the particular findings based on longitudinal studies (Van de Ven \& Huber, 1990). Therefore,

- A case study is suitable to generate answers to "how and why nations accomplish the sustainable competitiveness through nation branding"

- A case study is an applicable method to explore empirical findings based on a longitudinal nation-branding story.

\subsection{CASE SELECTION}

A fundamental question is often raised about the generalizability of an in-depth case study (Van de Ven \& Huber, 1990:216). "Case replication" is considered to be suitable to test the generality of key findings from a single longitudinal case study by comparing it with another longitudinal case, which means that cases should be selected on spatial and temporal criteria that provide meaningful comparisons (Leonard-Barton, 1988). It is necessary to decide the number of cases viewed sufficient for the generalization of empirical findings, which provides external validity (Yin, 2003: 51). The concept of competitiveness depends fundamentally on comparison (Buckley et al., 1988:178). A comparative approach across nations provides systematic evidence or patterns to support general findings and enables us to predict outcomes under specified conditions (Perry \& Robertson, 2002). In comparing nations, the triangular structure (Fig. 19) expresses the critical decisions, describing the three domains of decision-making: Why to Compare; What to Compare; and How to Compare (Perry \& Robertson, 2002). "Why to Compare" is an epistemological decision to find out the reasons why comparing across nations; "What to Compare" is to decide which concepts are central to the research question; "How to Compare" relates to the selection of the most suitable cases and replication logic for the process of analysis and evaluation.

Fig. 19 The science of comparing nations

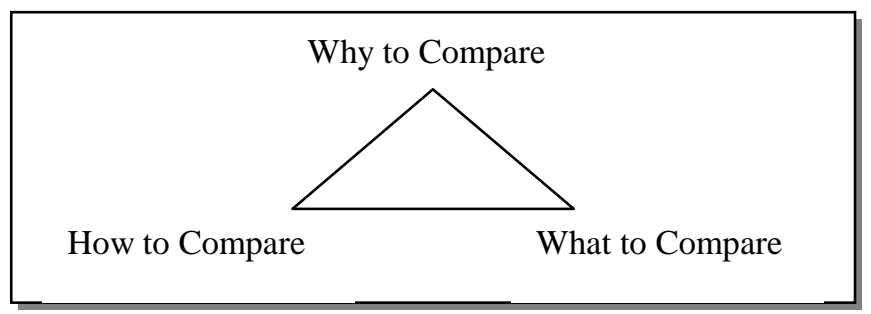

(Source: Perry \& Robertson, 2002:20) 
Selecting suitable cases to be studied has been considered as an important aspect of building theory (Yin, 2003; Verschuren \& Doorewaard, 1999; Eisenhardt, 1989). To select cases that are likely to provide external validity, the study adopts the three domains of decision-making described below.

\section{- "Why to Compare"}

Each nation has its own inherited aspects such as history, culture, values, and demographic variables. There are cross-national variations in institutional management systems, such as a government's plans, industrial strategies, policies, and systems of public and private decision-making (Porter, 1998; Lenway \& Murtha, 1994; Dunning, 1979). No two nations are able to set their strategies, use their resources, define their products, or implement their plans in the same way (Kotler et al., 1993). As a result, they take different paths to national development, which inevitably leads to nation-specific mechanisms.

Conducting comparative studies needs to map the relevant configurational patterns and to explain the similarities and the differences by considering the specific contingent conditions under which the postulated generative mechanisms operate (Tsoukas, 1989). Similarities between the units of analysis are explained by the generative mechanisms and the similar type of contingencies that have been responsible for the mechanisms. Differences may be due either to the operation of different generative mechanisms or to the different contingencies within which the operation of a similar set of mechanisms has taken place. Considering the generic notion of building a nation'a image and identity, the 'Nation-Branding Mechanism Model' has been presented, which encompasses a systematic process between contextual parts (i.e. branding actors and activities) that are involved in nation branding. By comparing the nation branding process with multiple nations, the study aims:

- To identify nation-specific branding mechanisms

- To identify the relevant contextual patterns in the nation branding process

- To identify similarities and differences in the nation branding process.

\section{- "What to Compare"}

To define the role of nation branding and create a strategic management tool on nation branding for the sustainable competitiveness of nations, the 'Nation-Branding Mechanism Model (NB-MM)' has been presented. The NB-MM articulates a sequence of branding phases, ranging from creating a nation-brand vision (C-NBV), setting a nation-brand goal (S-NBG), developing a nation-brand strategy (D-NBS), operating a nation-brand strategy (O-NBS), through to achieving the sustainable competitiveness for the nation. This study compares branding mechanisms within a system through the branding process.

Nations compete in the international arena, which contribute to building a nation's identity and image. To compare branding mechanisms between nation branding systems, branding behaviours in managing a nation's identity and image are highlighted. Meanwhile, 
country image is output-specific and is composed by multifaceted and diverse identities that enable to sustain a nation's developmental strength. That is, whether nations adopt branding behaviours based on a nation's reality or not is particularly considered, which enables us to understand branding mechanisms within a brand system.

Therefore, to identify nation-specific branding mechanisms and the relevant contextual patterns in the nation branding process, it must be decided what to compare with the reality for the nation brand. Researchers on the nation-banding context have highlighted various dimensions ${ }^{7}$ (e.g. tourism, investment, export, or public diplomacy) or their resources, such as industries, related to the nation brand's reality. In particular, FDI and exports are considered to be key assets in a nation's brand equity (Dinnie, 2008). 'FDI attraction' and 'export promotion' have been highlighted in improving a country's global competitiveness (Florek \& Conejo, 2007; Mihailovich, 2006; Papadopoulos, 2004; Kotler \& Gertner, 2002; Papadopoulos \& Heslop, 2002; Olins, 1999). With respect to the competitiveness context, these two dimensions stress competitiveness of a nation's industries and explain a national performance in global markets. With FDI and export branding behaviours, transnational companies (not only as the producers for international trade but also as the consumers deciding foreign investments) are the main nation branding actors. However, researchers have not yet fully explored this area and it remains a largely under-researched phenomenon (Capik, 2007; Szondi, 2007; Papadopoulos, 2004). Branding mechanisms focusing on FDI and export branding system are particularly important for empirical investigation. Therefore, our case study compares:

- Branding mechanisms on FDI and export branding systems of nations

- The contextual patterns in these branding processes and mechanisms of nations.

\section{- "How to Compare"}

When considering a comparative (or multiple-case) study, we need to deal with the number of cases and the replication approach (Yin, 2003). According to Verschuren and Doorewaard (1999), there are two choices about whether to select cases showing a minimum number of differences or cases representing a maximum number of differences. That is, it needs to be decided how many cases are required to justify the relevant evidence and how much of variation between the cases is permissable.

Nations have developed their brands with various strategies for the specific challenges that they face (Dinnie, 2008; Anholt, 2006a). Developing a coherent and strategic nation brand can take from decades through to centuries, following a natural evolutionary path (Szondi, 2008; Lebedenko, 2008; Lodge, 2006; Gudjonsson, 2005; Papadopoulos, 2004). A longitudinal approach based on historical perspective is highlighted for understanding comprehensive nation branding (Amine \& Chao, 2005; Damjan, 2005; Olins, 2002). When analysing the evolution and development of nation branding, it is important to understand

\footnotetext{
${ }^{7}$ Researchers refer to them as endorsed brands, functional sectors, product outputs, domains, and so on.
} 
and examine the context in which nation branding emerged (Szondi, 2008). In particular, Quelch and Jocz (2005) assert that performance should be tracked over time and compared from nation to nation. Based on the specific notion of nation branding, a comparative study needs intensive resources and time. To understand the mechanisms of the branding process, therefore, the study selects two cases that enable us to predict similar results (i.e. literal replications).

With a similar notion of a nation brand's longitudinal evolution, many determinants have to be considered to make the brand successful (Florek, 2005). However, to compare branding mechanisms on FDI and export branding systems, and to understand the contextual patterns in the branding processes and mechanisms, the cases need to distinguish the similar results through FDI and export branding. Reflecting the categorization of nations linked to building a nation's identity and image, the cases need to be selected within the same category based on auto-identification and country image taxonomy, which helps to address a similar input measure. With variation between cases, Verschuren and Doorewaard (1999) insist that if there is little knowledge of the subject to be examined, those cases that on the whole show many similarities (minimal variation) are preferred. Nation branding is in its infancy stage for academic research (Anholt, 2002b). Therefore, the study selects and compares those nations with minimal variation that provide more similarities than differences.

The basic theoretical constructs of the model are termed events (Newman \& Robey, 1992). There are the patterns and correlates of the occurrences of events (Yamaguchi, 1991). Because the model includes the prospect of change in the established patterns, the mechanisms for achieving change must also be prescribed (Newman \& Robey, 1992:253). Each individual case, therefore, consists of multiple embedded cases, i.e. multiple events. According to Newman and Robey (1992), events are comprised with episodes and encounters. An episode refers to a set of activities standing for the end of one sequence of activities and the beginning of another, and encounters are the most likely times in a process that mark the beginnings and ends of episodes.

The greatest opportunity for change to episode occurs during the critical encounters (Newman \& Robey, 1992:253). That is, time is referred to as another critical source in a comparative study. The temporal dimension should be reflected along which the comparion has been undertaken (Tsoukas, 1989). To gain understanding of the pattern of competitivness (Hughes, 1993), the time horizon of the analysis needs to be spelled out (Buckley et al., 1988). In settling for a longitudinal approach, there is a period of evolutionary change, the so-called epoch (by influential leaders) and this type of approach can be adapted for empirical study with process context (Melin, 1992). To understand branding mechanisms on FDI and export branding systems and the contextual patterns in branding processes and mechanisms, this study adopts each case with multiple events that comprise critical encounters and episodes, and then proceeds to compare them. 


\subsection{SELECTED CASES}

Based on these three domains of decision-making to select cases (section 4.2), this research suggests the criteria to select cases as follows:

- Cases that have distinguished their own nation-specific development path

- Cases that have developed their own FDI or export branding system

- Cases that have been positioned within a similar category level on auto-identification and country image, implying similar levels of nation brand status

- Cases that highlight a period of evolutionary change (i.e. epoch) brought about by influential leaders

- Cases that explain multiple events based on longitudinal scope.

\section{THE SELECTION OF KOREA AND IREALND}

Korea and Ireland have been identified as nation brands which have been built through their country behaviours (Anholt, 2006b). As reseachers (Gertner, 2007; Gertner \& Kotler, 2004; Papadopoulos, 2004; O’Donovan, 2004; Olins, 1999; Porter, 1998) highlight, Korea and Ireland have employed export or FDI promotion as a key ingredient in their economic development strategies and nation brand image projection.

The two countries are geographically located in different region, Asia and Europe. They are characterized by demography. Historically, the two nations had confronted painful external relationships in their geographic regions and overcame economic crises. However, both countries represent rapid economic growth over fairly short periods. Korea has established its economic achievements by the export-centred brand development since 1960s. By the mid 1990s, Korea had been transformed into the third largest economy in Asia, earning its reputation as a so-called 'Asian tiger.' Ireland, overcoming a fiscal crisis in the early 1980s, recorded huge inflows of FDI investment since the late 1980s and double-digit export growth through the period 1991-2001. By the middle of 1990s, Ireland had been recognized as a 'Celtic tiger' in the market.

Korea and Ireland are positioned as innovation-driven countries. They highlight 'innovation networks' (i.e. partnerships between companies or countries which are thought to be more effective than keeping research and development "in-house") that are effective at taking developments from other nations or companies and turning them into commercial products $^{8}$. According to the Innovation Capability Index (UNCTAD, 2005) calculating for 117 nations for the years 1995 and 2001, Ireland and Korea are categorized as highly innovative countries and ranked in similar positions.

\footnotetext{
${ }^{8}$ The study has been carried out by US research consultancy Forrester, which has identified Ireland and Korea as 'transformer' position for innovation (National Innovation Networks Q4 2006, The Forrester Wave).
} 
During the period 1985-2000, at the four-digit Standard International Trade Classification (SITC, Rev. 2) level, the most dynamic products come mainly from the hightechnology group (UNCTAD, 2002:146). Ireland and Korea have built their international production competitiveness and, in particular, highlighted their strengths in hightechnology industries. That is to say, competitive identity and image for Korea and Ireland have been reflected through changed reality based on high-technology and innovativeness. According to the classification of world economies based on GNI per capita (World Bank, 2006), Ireland and Korea are positioning themselves as leading countries in high-income economies.

Ireland and Korea have both positioned themselves within a similar category level, both as innovative countries with Asian or Celtic tiger images which represent rapid economic growth. Meantime, they have established different branding paths, by adopting FDI or export-oriented branding system. A unique brand development system in each of the two countries is suitable to identify nation-specific branding mechanism and to identify the relevant contextual patterns in the nation branding process. As Korea and Ireland have adopted a different branding system, they can provide valuable notions on the similarities and differences in generating their nation branding process.

\subsection{CASE STUDY PROTOCOL}

A host of theoretical and practical problems have to be addressed in conducting longitudinal field research, which include questions of how to deal with time, site selection, choices about data collection and degrees of involvement, and handling the problems typically associated with case studies (Van de Ven \& Huber, 1990:216). The protocol is a major way of increasing the reliability of case study research and is intended to direct the carrying out of the data collection (Yin, 2003:67). Reliability concerns whether the research can replicate - in a later study - the similar findings and conclusions when repeating the same case again, and the goal of reliability is to lessen the errors and biases in a study before entering the field (Yin, 2003; Eisenhardt, 1989). In line with increasing the reliability, a case study protocol needs to be designed to provide case study tactics.

Triangulation in crafting a case study protocol enables us to intensify the construct validity (Saunders et al., 2007; Yin, 2003; Eisenhardt, 1989). In line with theory building through a case study, it is necessary to triangulate multiple sources of data (known as data triangulation), using different data collection techniques (known as method triangulation) within one study (Saunders, 2007:139). Data and method triangulations are needed to help decide which devices (e.g. questionnaires and observation forms), and the medium of communication (e.g. interview, the telephone, mail, Internet, etc), with deciding primary or secondary data based on credibility (Cooper \& Schindler, 2003). A triangulation approach aims to corroborate each new fact or phenomenon (Yin, 2003:99). Through the 
convergence of several different sources of information (Fig. 20), empirical findings from a case study can be much more convincing and accurate (Ibid: 98 ).

Fig. 20 Convergence of evidence

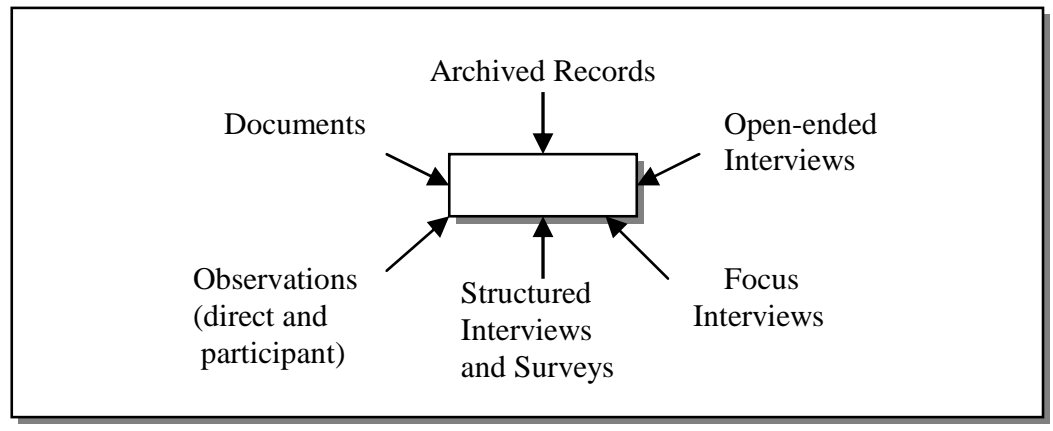

(Source: Yin, 2003:100)

To increase the reliability and validity of case studies, based upon the above-defined techniques, we adopt triangulation with data sources and collecting techniques. The data collection protocol (see Appendix) is as follows:

- To develop a nation-branding model on the sustainable competitiveness, our study primarily focuses on gathering the objective measures with respect to the sustenance of competitiveness. Information on each case is obtained by benchmarking the secondary data from the leading international data agencies such as UNCTAD, the UN Human Development Agency, the OECD, the Economist Intelligence Unit, and the World Trade Organization. In particular, to understand how Ireland and Korea have been involved in FDI and Export promotions, we collect the secondary data of these trends from the World Investment Report series (1991-2006) published by UNCTAD.

- Along with the secondary data, this research collects the primary data to obtain the locus for Korea's and Ireland's branding processes. Preliminary interviews by questionnaire are carried out with selected experts in national governments and promotion agencies in both Korea and Ireland (see Appendix: A4). For practical reasons such as distance, time and money (Swanborn, 1996), both direct and indirect interviews are conducted. A questionnaire has been developed containing both open and closed-ended questions (see Appendix: A2).

- With respect to the longitudinal approach based on encounters and episodes, multiple documents (e.g. annual reports and research reports) and archived records related to the nation branding process are searched. In particular, the national development plans of Korea and Ireland are studied. Records relevant to FDI and Export promotions which have been published by the governments and promotion agencies of each country are obtained. To provide more objective data, we explore the related studies about Korea and Ireland. Media (e.g. newspapers, television, email and so on) are addressed to a wider audience (Verschuren \& Doorewaard, 
1999). Data from the media are also collected. In particular, country images of both nations are closely observed.

In a comparative case study, researchers suggest the hierarchic method such as analyzing Within-Case data and searching Cross-Case patterns (Eisenhardt, 1989). Verschuren and Doorewaard (1999:166) recommend two stages. The initial stage is to examine the separate cases independently; in the second stage, based on the results from the first stage, it is necessary to make a comparative analysis of the coherent body of all cases studied. Using this procedure, we expect to find explanations for the similarities and differences between the various cases (Ibid). Yin (2003:17) argues that case analysis shows all the evidence and addresses the most significant aspect of the particular case study, and it is important to select specific analytical strategies or techniques (Table 34).

Table 34 Analytical techniques

\begin{tabular}{|c|l|}
\hline $\begin{array}{c}\text { Pattern } \\
\text { Matching }\end{array}$ & $\begin{array}{l}\text {-A logic comparing empirically based patterns that may be related to the dependent or } \\
\text { the independent variables of study }\end{array}$ \\
\hline $\begin{array}{c}\text { Explanation } \\
\text { Building }\end{array}$ & $\begin{array}{l}\text {-A special type of pattern matching } \\
\text {-The procedure is more difficult and therefore deserves separate attention }\end{array}$ \\
\hline $\begin{array}{c}\text { Time-Series } \\
\text { Analysis }\end{array}$ & $\begin{array}{l}\text {-An analysis following many intricate patterns between variables and identifying the } \\
\text { specific indicators to be traced over time }\end{array}$ \\
\hline Logic Models & $\begin{array}{l}\text {-A technique stipulating a complex chain of events over time by forming a repeated } \\
\text { cause-effect-cause-effect pattern }\end{array}$ \\
\hline $\begin{array}{c}\text { Cross-Case } \\
\text { Synthesis }\end{array}$ & $\begin{array}{l}\text {-A technique applying specifically to the analysis of multiple cases consisting of at least } \\
\text { two cases }\end{array}$ \\
\hline
\end{tabular}

(Source: Yin, 2003:116-35)

To develop internal and external validity ${ }^{9}$, this research adopts the pattern-matching and cross-case analytical technique. In the first stage, the study analyses each case, i.e. branding of Korea and branding of Ireland. In particular, to define branding mechanisms on FDI and export branding systems and the contextual patterns in branding processes and mechanisms, branding of Korea is analyzed with multiple branding events based on encounters and episodes. Branding of Ireland is analyzed in a similar way. Based on the results from the first stage, we compare branding of Korea and branding of Ireland. Finally, this research defines the similarities and differences between both cases in terms of the contextual patterns in branding processes and mechanisms within FDI and export branding systems.

\footnotetext{
${ }^{9}$ Internal validity is about establishing a causal relationship and external validity relates to establishing the domain to which a study's findings can be generalized (Kidder \& Judd, 1986:26-29).
} 


\subsection{CONCLUSION}

To test the developed research model 'Nation-Branding Mechanism Model', a case study methodology based on a comparative approach across nations is determined to be a suitable operational approach.

Based on the formulated three domains of selection, Korea and Ireland are two countries that qualify to obtain the empirical data. As found in the literature study (Chapter 2) and previous section (4.2), FDI and export revenue have been identified as the outcomes of nation branding and, at the same time, the competitive process in international business. In particular, the gap between the growth rate of exports and FDI outflows since 1985 has dramatically increased, which influenced the competitiveness of nations in global markets. Since 1960s, Korea has focused on export branding aligned with national development plans. Since 1985, Ireland has rebranded, focusing on FDI promotion. Korea's and Ireland's branding can explain their nation-specific branding system and, moreover, identify branding mechanisms that derive from their nation branding process within the system. 


\section{CHAPTER 5 BRANDING OF KOREA}

\subsection{BACKGROUND}

Korea, officially the Republic of Korea (ROK), is geographically located in East Asia, being surrounded by the Yellow Sea to the west and East Sea to the south east. About 50 million people inhabit in Korea. Gojoseon is recorded as the first Korean dynasty founded by DanGun under the basic principle of "Hong-ik", i.e. "Broad benefits to the people."

Hangeul, which was created by King Sejong (1443), is commonly spoken as the authentic national language. Although mainly based on Confucianism, many Korean people also adhere to the Christian or Buddism religion.

Korea, after the Joseon Dynasty (1392-1910), was colonized by Japan (1910-1945). Through the colonial

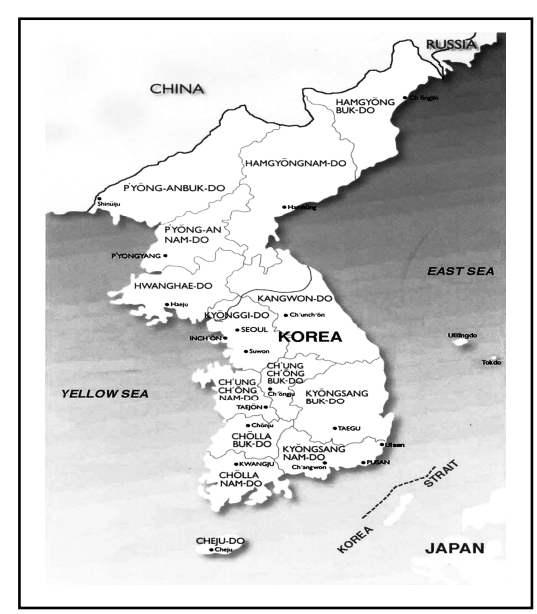
period, the quality of life of ordinary Koreans was devastated. The Korean War (1950-53) divided the country into South and North Korea, which damaged over 80 per cent of industial and infrastructure facilities and destroyed over half of dwellings in the capital city, Seoul. The Korean economy was severely damaged. President Rhee, Syng Man governed Korean during 1948-1960, and relied heavily on foreign aid from the USA. However, the government barely articulated any distinct strategic direction of economic growth for Korean. In April 1960, the Democratic Party government of Chang, Myun replaced the previous regime, but the Korean economic condition deteriorated further. The GNP per capita in 1962 amounted to only \$ 87. The Supreme Council of National Reconstruction (SCNR) under General Park, Chung Hee on May 1961 established a new government, aiming to rebuild Korea from this severely deteriorated state.

Korea was transformed into a new phase of economic development. The Korean image was stereotyped as 'the divided and poor country' or 'Korean War'. However, a new Government in 1962 developed the first Five-Year Plan (FYP) as the national strategy, pursuing the Korea-brand as an Industrialized Korea founded on export along with science and technology development. Emphasizing science and technology values for export and industry development, Korea presented its third and fourth FYPs in the 1970s, and became one of the Newly Industrialising Countries (NICs). In the 1980s and 1990s, the Five-Year Plans were invigorated for accomplishing Industrialized Korea towards a sustainable competitiveness for Korea. Throughout these Five-Year Plans, Korea envisaged plans for place development of building attractive resources and for economic diplomacy of establishing the relationship based on technological and cultural exchanges with other countries. 
Successfully hosting the Asian Games in 1986 and the Olympic Games in 1988, Korea officially advanced from the status of a developing country at the GATT in 1989. By the mid-1990s, it became the third largest economy in Asia, and is now recognized as one of the "Asian Tigers." In spite of sharp economic downturn during the 1997-98 financial crisis, it hosted the World Cup in 2002.

'Dynamic Korea' is symbolized as a national slogan, representing an ever-continuing process of change and creation by Korean people.

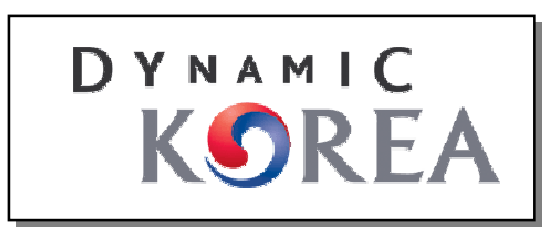

\subsection{CASE STUDY DESIGN}

Korea's image since the Korean War (1950-53) has been perceived as a poor country economically and insecure geographically. However, coming into the 2000s Korea has achieved economic success, which helps its position as one of high-economy countries and its reputation as an "Asian Tiger." To explore how Korea has achieved its reputation and competitiveness by nation branding, this study focuses on empirical findings throughout the nation branding events ranged from the 1960s through the 1990s.

Korea transformed into a new economic development era with its Five-Year Plans (1962-1997). During the periods of FYPs, Korea created the brand Korea - a type of ESTI - based on export, science \& technology, and industry development. Therefore, our research highlights the brand development process with ESTI-brand system and explores branding process of how Korea's ESTI-brand system has driven a highly innovative country, and allowed it to complete its Five-Year Plans.

Based on the key concept of nation branding (2.2.5, p.34-45), the whole period of FYPs is suitable to explore the context of a strategic fit between a nation brand and a national strategy. The period can be divided into certain episodes in terms of developing and managing brand strategy, brand identity and image by branding actors. The first and second Five-Year Plans (1962-1971) provided a ground period of creating the ESTI-brand system. The third and fourth Plans (1972-1981) continued to develop it, but reinforced the brand system with strategic decisions of national strategies. Coming to the 1980s, there were several changes in Korea in terms of national leader, political and social development, which were continued into the 1990s. Aiming to identify Korean-specific branding mechanisms in the ESTI-brand system and contextual patterns in the branding process of the 'Nation-Branding Mechanism Model,' our study distinguishes Korea branding episodes by three periods of branding encounters as follows:

- ESTI-I: The period of branding episode from 1962 to 1971

- ESTI-II: The period of branding episode from 1972 to 1981

- ESTI-III: The period of branding episode from 1982 to 1997 


\subsection{CREATING A KOREA-BRAND VISION (C-KBV)}

\subsubsection{C-KBV: ESTI-I (1962-1971)}

With his determined belief in building a new nation for Korean people, President Park, Jung Hee (then a military General) on May 1961 established a regime along with the Supreme Council of National Reconstruction (SCNR). With his first priority to solve the economic and social problems that Korean people had been suffering since the war, President Park and the SCNR designated a planning group that was composed of economic experts who had been working as economic policy makers, and assigned to analyze the current internal and external status of Korea.

Based on the drafts of the three-year plan (1959) and the five-year plan (1961) that had been drawn up previously, the planning group analyzed Korea's current internal and external positions. Korea is geographically adjacent to Communist North Korea and China, which has threatened Korean people and has directly affected the nation's safety and survival. For national security and economic development (e.g. foreign aid, investment, or trade), Korea has been closely linked with USA and Japan. The financial assistance from foreign nations has given some opportunities for national reconstruction on the one hand, but the dependence on foreign aid gave rise to a major economic problem on the other hand. To make matters worse, it was imperative to import essential goods for the people. In the meantime, Korea was considered to have one of the highest estimated population growth rates in Asia, relative to possessing arable land at only around 20-30 per cent of its total area. The diligent and motivated people who have relatively high levels of literacy ${ }^{10}$ and skills are therefore the only available resources that can offer a comparative advantage to Korea.

Reflecting on the present advantages and disadvantages, President Park and the SCNR set a national vision building "Industrialized Korea on the basis of 'Jarip-Gyongje' with a self-reliant and independent industrial economy." The Economic Planning Board (EPB) was immediately organized and assigned to take responsibility for developing Korea's strategic direction in the macro perspective and comprehensively coordinating the government departments. In particular, President Park urged the creation of a national development plan for building the science \& technology-based and export-oriented industries. Putting 'Jarip-Gyongje' into concrete terms, President Park in 1964 declared a brand vision of building 'Industrialized Korea based on the Export-first Principle'. In particular, President Park strongly expressed the excellence of the Korean people, which was reflected in developing the principles of 'Export first' and 'Industrialization'. The president appealed to the people to devote all their energies to export promotion. During the middle of 1960s, the President and Government envisioned a bright picture of

\footnotetext{
${ }^{10}$ In the 1960 s the illiteracy rate was already well below 10 per cent (Harvie \& Lee, 2003:268)
} 
accomplishing a complete 'Jarip-Gyongje' based on economic and social development by the early1980s.

\subsubsection{C-KBV: ESTI-II (1972-1981)}

On July 1969, President Nixon of the United States announced that allied nations would henceforth be expected to take care of their own military defense. As a result of the Nixon Doctrine, Korea was confronted with a threat to national security. Meanwhile, there was an opportunistic prospect in international market trends that created a boom in the heavy engineering and chemical industries. The President and Government challenged industries to be aggressive and seized the opportunity for upgrading export industries and accelerating export promotion. In his New Year's address in 1973, the President announced the 'Heavy and Chemical Industrialization (HCI) Era' for Korea and shared his belief with the people that they needed to prepare and respect a technology-oriented mind and to export in all industries. President Park, in articulating his national vision, had the insight to envision the 'Saemaul Undong' not only for the improvement of the "environment" quality of community life but also for the spiritual reform of Korean people in rebuilding Korea according to the ESTI-brand system.

In 1976, the KDI (Korea Development Institute) and twenty Task Force teams, consisting of national expertise from academic, business, research institutes and the Government, and particularly encompassing 28 advisors from the World Bank and others, suggested the 15-Year Plan (1977-1991) for economic and social advancement. The Government envisaged a new brand vision of attaining 'Jarip-Gyongje' by strengthening the technology-led HCIs, innovating the promotion of science and technology, and reinforcing both export promotion and trade liberalization. Furthermore, the plan emphasized social equity through social welfare and equality, as well as economic prospects. Reporting on the "New Strategy for 1980s", in January 1979 the Economic Planning Board (EPB) proposed to President Park that it was time for Korea to adopt a market-based economy and build the balance of social and economic growth on the basis of stability, autonomy, and openness. On March 1979, the President and Government convened a policy meeting and came to an agreement about moving to 'a well-balanced and stable national economic system.' Establishing a 'Jarip-Sungjang' for self-sustaining economic and social developments based on stability, autonomy and openness was also envisaged as the national vision for 1980s.

\subsubsection{C-KBV: ESTI-III (1982-1997)}

In the 1980s, the world economy changed significantly. With a huge shift in international production, the share of the United States declined rapidly. The US took special measures to protect its knowledge resources such as technology and intellectual property on the one hand and pressured other nations to open their markets on the other hand. The Korean Government prospected that the world economy since 1980s became 
dominated by the technology revolution and that nations would be striving for competitive advantage in technology. In the full assurance that Korea had accumulated sufficient capability in science and technology, President Chun, Doo Hwan and the Government had a mutual agreement about moving toward a well-balanced and stabilized national economic system and emphasized on building Korea as a science and technology-advanced country. During the middle of the 1980s, economic and political reform was initiated in the Soviet Union. The Soviet and Eastern markets became a new emerging export market that needed an approach to building industrial cooperation. The Uruguay Round of the GATT commenced in September 1986 and began the process of opening trade in services. Internally, Korea held the '86 Asian Games' and the '88 Seoul Olympics.' With the ultimate goal of normalized relations with the People's Republic of China and Soviet Union, President Roh, Tae Woo and the Government declared a policy of Nordpolitik.

Immediately on being inaugurated in June 1992, the new President Kim, Young Sam declared his intention to build a 'New Korea based on the New Economy.' The Government convened expertise from academia, business and governments in order to prepare a preliminary plan. On March 1993, President Kim made a special statement to the public: "In order to restructure our economy, I advocate 'New Economy' withdrawing many regulations that have constrained our enterprises' activities and enabling them to act more freely. It is necessary, therefore, to innovate national finance and organizations." In the following year, the President declared 'Segyehwa (i.e. globalization)' and encouraged the people and enterprises to adopt an entrepreneurial spirit and take initiative.

\subsection{SETTING A KOREA-BRAND GOAL (S-KBG)}

The Economic Planning Board (EPB) integrated the Budget Bureau and the General Planning Bureau, centralized both planning and budgeting authorities, which enables the elimination of conflicts between the planning and ministries' interests, and invigorated the coordinating and supporting role for short-term stability or long-term investments in national economic planning. As the first priority in national development planning, the EPB in cooperation with an advisory board and working committee under SCNR created five-year plans (FYPs) and set national economic goals (Table 35) to establish a base for 'Jarip-Gyongje' in 1960s, achieve the system for 'Jarip-Gyongje' during the 1970s. Through subsequent FYPs over the periods of 1980s through 1990s, they aim to maintain 'Jarip-Gyongje' as self-supportive economic system and to continue with 'Jarip-Sungjang' for self-sustaining development. 
Table 35 Expected national economic outcomes through Five-Year Plans

\begin{tabular}{|c|c|c|c|c|c|c|c|}
\hline & $\begin{array}{c}\text { First } \\
\text { FYP }^{\mathrm{a}} \\
(1962-66)\end{array}$ & $\begin{array}{c}\text { Second } \\
\text { FYP } \\
(1967-71)\end{array}$ & $\begin{array}{c}\text { Third } \\
\text { FYP } \\
(1972-76)\end{array}$ & $\begin{array}{c}\text { Fourth } \\
\text { FYP } \\
(1977-81)\end{array}$ & $\begin{array}{c}\text { Fifth } \\
\text { FYP } \\
(1982-86)\end{array}$ & $\begin{array}{c}\text { Sixth } \\
\text { FYP }\end{array}$ & $\begin{array}{c}\text { New } \\
\text { Economy } \\
\text { FYP }\end{array}$ \\
\hline GNP (\%) & 7.1 & 7.0 & 8.6 & 9.2 & 7.6 & 7.3 & 6.9 \\
\hline $\begin{array}{c}\text { Unemployment } \\
(\%)\end{array}$ & 8.5 & 6.1 & 4.2 & 4.0 & 4.2 & 3.7 & NA \\
\hline $\begin{array}{l}\text { Note1. a) indicates complementary magnitude during 1964-1966. } \\
\text { Note2. The original FYPs comprehend national economic goals in terms of economic growth rate, }\end{array}$ \\
unemployment, GNP deflator, consumer prices, total currency, product export \& import rate, \\
industrial structure, and current transaction. \\
Note3. The study limits to present average annual growth rate of GNP and unemployment for comparable \\
index.
\end{tabular}

(Source: Kang, 2000; KOTRA, 1992; Korea Five Year Plans)

\subsubsection{S-KBG: ESTI-I (1962-1971)}

In line with medium-term national goal (1962-1966) establishing a base for 'JaripGyongje,' the EPB simultaneously analysed the current status of national resources and competences. Korea was suffering from a poor endowment of natural resources. Compared to the quality of welfare facilities, its population increased up to 2.9 per cent per year, which gave rise to a high death rate and limited investment for developing national resources to generate economic growth. The domestic market was hardly established enough to support enterprise activities. Enterprises operated on a small scale in certain industries, which made them less competitive in the international markets. In respect of export and import structures in 1961, export products were mainly from primary industries, i.e. agricultural products, and their sales relied on Japanese markets. Imports were imperative due to the shortage of raw materials locally. Particularly in science and technology development, there was little investment in R\&D.

Meanwhile, the world's industrialized economies in 1960s enlarged and international trade volume increased. The free economy became prevalent. Korea's market expanded from the USA into Western Europe. Recognizing the key market opportunities in the free economy, the EPB primarily focused on the expansion of secondary industries based on mining and manufacturing sectors and on improvement of enterprises' competitiveness in the international markets, which was reflected in the decision to export products. Under the national vision establishing 'Industrialized Korea on the basis of 'Jarip-Gyongje' along with brand vision of the 'Export-first Principle', the EPB in collaboration with other government ministries set a target to build 'Export Korea'. In particular, the export goal was for an average of US \$140million during the first FYP and export products in 1966 came from manufacturing industries up to 57 per cent. 


\subsubsection{S-KBG: ESTI-II (1972-1981)}

To expand the system for 'Jarip-Gyongje' as the second medium-term goal and to accelerate 'Export Korea', in 1969 the Government organized a task force (TF) within the export promotion agency (KOTRA). TF analyzed the market environment and national resources in a step-by-step procedure. Primarily, it focused on prospecting how international trade and economic trends are deployed. Based on that, it analyzed market share per product and country categories, competitive nations, importing nations, as well as national supply capacities and strategic directions, and prospects' market demands for both existing and new products. Integrating the analyses and plans by $\mathrm{TF}$, the Ministry of Commerce and Industry in 1972 presented the expected outcomes for long-term export goals (Table 36) in order to achieve 'Export US\$10billion' and 'National income ${ }^{11}$ per head of US\$1,000' in 1980 .

Table 36 Long-term export-planning goals: 1972-1980

\begin{tabular}{|c|l|l|l|l|l|l|l|l|l|}
\hline & 1972 & 1973 & 1974 & 1975 & 1976 & 1977 & 1978 & 1979 & 1980 \\
\hline $\begin{array}{c}\text { Export Amount } \\
\text { (US\$ M) }\end{array}$ & 1,800 & 2,350 & 3,000 & 3,750 & 4,600 & 5,600 & 6,800 & 8,250 & 10,000 \\
\hline
\end{tabular}

(Source: KOTRA, 2002; The Ministry of Commerce and Industry, Korea)

Coming into the 1970s, international markets rapidly changed. The US economy declined. The USA started taking protective measures, which affected world trade. Industrialized nations reinforced import restrictions by adding import taxes. Experiencing the first oil shock, nations tried to retain their national resources. Korea had deeply relied on its trade relations with both the USA and Japan (Table 37), which came to threaten further export expansion.

Table 37 The pattern of export dependence on the USA and Japan in Asia NICs

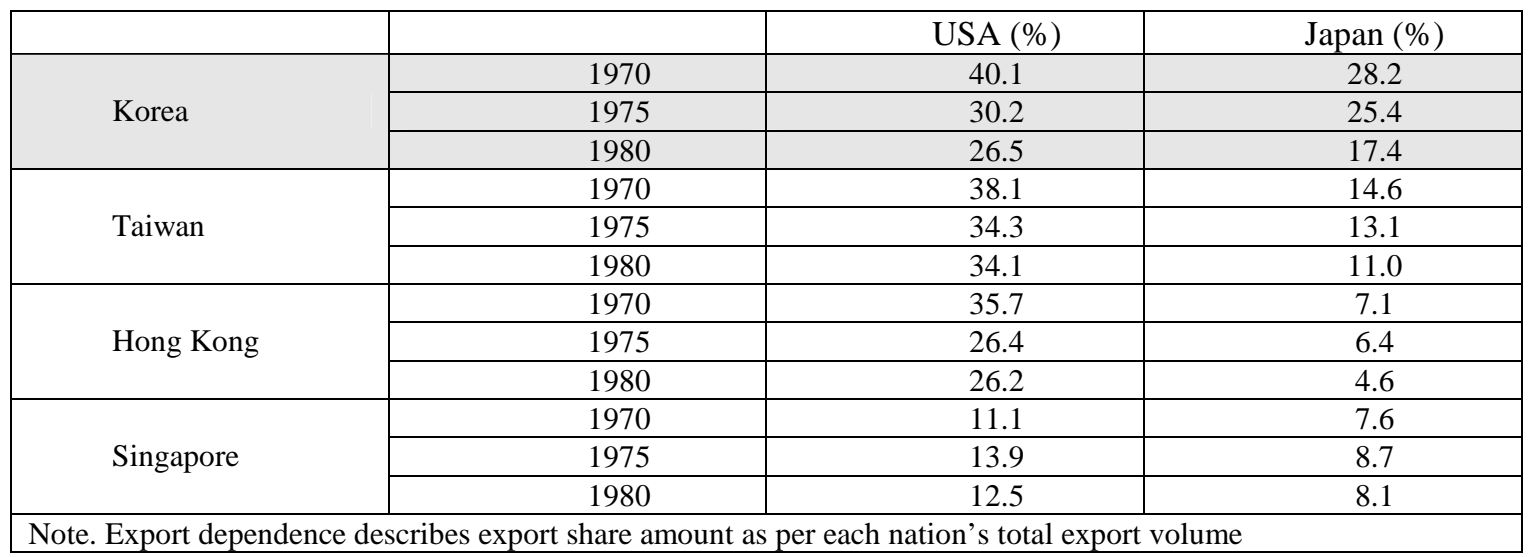

(Source: KOTRA, 1992; IMF, Yearbook)

\footnotetext{
${ }^{11}$ National income per head recorded US\$167 in 1969 (The Second FYP' General Evaluation Report,1972:323)
} 
With the shift in international production, industrialized nations rapidly transformed to build their own intensive technology and high value-added industrial structures. Newly Industrialized Countries (NICs) entered into the international market, which affected the light industrial market and intensified market competition in HCIs. Their export market shares in manufacturing sector (Table 38) expanded. There were only a few options to exploit new markets, such as China, Eastern Europe, Central and South America, and Africa.

Table 38 Export market shares of main industrial products

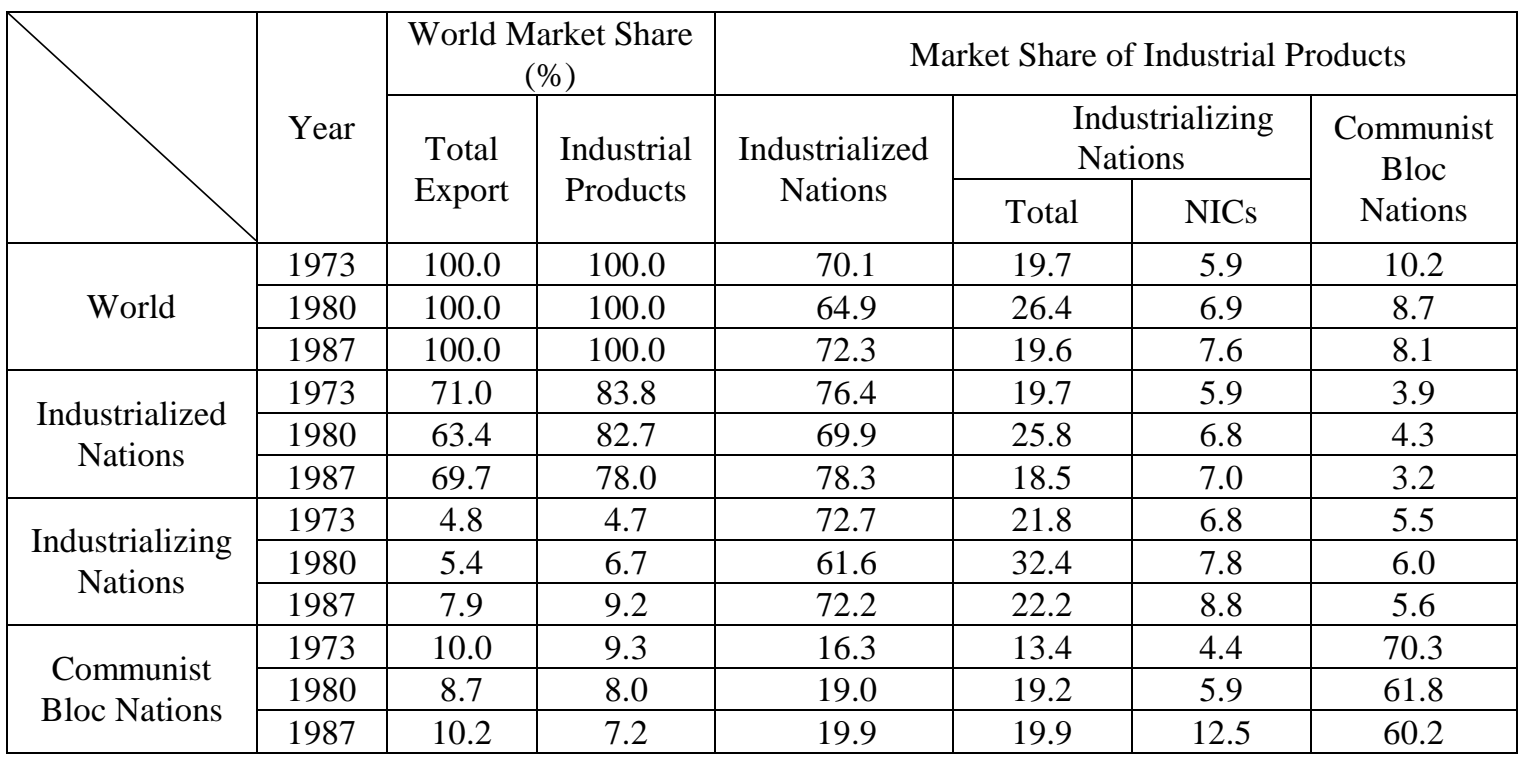

(Source: KOTRA, 1992; UNCTAD Database)

Since the third FYP (1972-76), the Government established its medium to long-term goals on the basis of sectors as per the ministries, and the EPB aggregated and coordinated them. To reinforce the system for 'Jarip-Gyongje' and align with the external market force and national industry condition in more efficient and effective ways, the Government in 1973 established the Committee for a long-term economic future. In particular, it decided to concentrate on "Heavy and Chemical Industries (HCIs), i.e. iron \& steel, petrochemicals, shipbuilding, electronics, nonferrous metals and machinery." Expecting the development of related industries as well as HCIs, the Government expected that the manufacturing sector in the secondary industries would increase by up to 133.2 per cent between 1970 and 1976 (Table 39). Within the total manufacturing sector, HCIs would constitute $40.5 \%$ by 1976 , which increased by up to 163.7 per cent compared to 1970 . Moreover, light industry constituted $59.5 \%$ of manufacturing export by 1976 . That is, the Government planned to reinforce the manufacturing industry by transforming from light industry to HCIs. 
Table 39 The manufacturing Industry structure: 1970-1976

\begin{tabular}{|c|c|c|c|}
\hline & 1970 & 1976 & $\begin{array}{c}\text { The rate of increase (\%) } \\
(1970-1976)\end{array}$ \\
\hline Manufacturing industry & 100.0 & 100.0 & 133.3 \\
\hline HCIs & 35.9 & 40.5 & 163.7 \\
\hline Light industry & 64.1 & 59.5 & 116.3 \\
\hline
\end{tabular}

(Source: The Third Five-Year Plan, 1971:12)

Along with the strategic expansion of HCIs and its expected goals, the Ministry of Commerce and Industry adjusted expected outcomes for its long-term export goals (Table 40). In a revised plan, export goals indicated that the manufacturing sectors for export were prominently targeted at 28.4 per cent compared to other sectors and, in particular, HCIs products in the manufacturing sector accounted for 51.5 per cent of exports between 1972 and 1976.

Table 40 Export goals of industrial sectors and products (HCIs and Light Industry Products)

\begin{tabular}{|c|c|c|c|c|}
\hline & 1971 & 1972 & 1976 & \multirow[b]{2}{*}{$\begin{array}{l}\text { Average rate of } \\
\text { Increase (1972-76) }\end{array}$} \\
\hline & $\begin{array}{c}\text { Component ratio } \\
(\%)\end{array}$ & $\begin{array}{c}\text { Component ratio } \\
(\%)\end{array}$ & $\begin{array}{c}\text { Component ratio } \\
(\%)\end{array}$ & \\
\hline Total & 100.0 & 100.0 & 100.0 & 27.0 \\
\hline Agricultural sector & 3.0 & 2.3 & 2.3 & 22.3 \\
\hline Fisheries sector & 7.7 & 6.7 & 5.4 & 18.6 \\
\hline Mining sector & 3.5 & 2.7 & 1.6 & 9.3 \\
\hline $\begin{array}{l}\text { Manufacturing } \\
\text { sector }\end{array}$ & 85.8 & 88.1 & 90.7 & 28.4 \\
\hline $\begin{array}{l}\text { Manufacturing } \\
\text { products }\end{array}$ & 100.0 & 100.0 & 100.0 & 28.4 \\
\hline A. HCIs Products & 19.1 & 25.1 & 38.6 & 51.5 \\
\hline (1) petrochemicals & 4.9 & 4.1 & 6.6 & 45.7 \\
\hline (2) iron \& steel & 4.2 & 7.4 & 7.1 & 50.8 \\
\hline (3) machinery & 0.3 & 0.8 & 0.9 & 95.6 \\
\hline (4) electronics & 8.3 & 10.1 & 15.3 & 45.2 \\
\hline (5) shipbuilding & 1.4 & 2.7 & 8.7 & 58.8 \\
\hline $\begin{array}{l}\text { B. Light Industry } \\
\text { Products }\end{array}$ & 80.9 & 74.9 & 61.4 & 21.0 \\
\hline
\end{tabular}

(Source: 한국무역협회 KITA, 1973:239-240)

\subsubsection{S-KBG: ESTI-III (1982-1997)}

The World economy stabilized and export competition intensified. The Government analyzed that in spite of trade restriction, industrialized nations in 1980s would increase imports in manufactured products, and therefore that Korea needed to increase its export market and reinforce its export market share through the qualified manufactured products. In the $4^{\text {th }}$ FYP, the Government focused on solidifying industry structures to the higher degree based on the development of science and technology in order to meet the need for 
export competitiveness. Coming to 1980s, nations accelerated developments of technologybased industries and concentrated on industrial restructuring, particularly reinforcing protective measures for trade markets and knowledge resources. Even though Korea in the 1970s had already set the strategic goal of intensifying science and technology development throughout the 15-Year Plan, the extent of development in science and technology had progressed slowly. Compared to countries in industrialized economy (Table 41), science and technology had contributed insignificantly to Korea's economic growth.

Table 41 Contributions of main sources in national economic growth (\%)

\begin{tabular}{|l|l|c|c|c|c|c|c|}
\hline Country & Year & $\begin{array}{c}\text { Growth } \\
\text { rate of } \\
\text { national } \\
\text { income }\end{array}$ & $\begin{array}{c}\text { Work } \\
\text { force } \\
\text { (Labor) }\end{array}$ & Capital & $\begin{array}{c}\text { Labor } \\
\text { mobility } \\
\text { between } \\
\text { industries }\end{array}$ & $\begin{array}{c}\text { Economy } \\
\text { of } \\
\text { Scale }\end{array}$ & $\begin{array}{l}\text { Technology } \\
\text { advancement }\end{array}$ \\
\hline Korea & $1966-76$ & 9.7 & 3.9 & 2.1 & 0.8 & 2.2 & 0.7 \\
\hline Japan & $1953-71$ & 8.81 & 1.85 & 2.10 & 0.95 & 1.94 & 1.97 \\
\hline USA & $1948-69$ & 4.0 & 1.30 & 0.79 & 0.30 & 0.42 & 1.19 \\
\hline Canada & $1950-67$ & 4.95 & 1.85 & 1.14 & 0.64 & 0.66 & 0.66 \\
\hline UK & $1950-62$ & 2.38 & 0.60 & 0.51 & 0.12 & 0.36 & 0.79 \\
\hline France & $1950-62$ & 4.70 & 0.45 & 0.79 & 0.95 & 1.00 & 1.51 \\
\hline Germany & $1950-62$ & 6.27 & 1.37 & 1.41 & 1.01 & 1.61 & 0.87 \\
\hline Netherlands & $1950-62$ & 4.10 & 0.87 & 1.04 & 0.63 & 0.78 & 0.78 \\
\hline
\end{tabular}

(Source: KDI, 1977:12)

The fifth FYP (1982-86) emphasized the development of technology-intensive industries (i.e. Precision Chemistry and Machinery, Information, Electronics such as televisions, videocassette recorders and semiconductor-related products) and accelerated technology-led HCIs. The Government in 1985 organized the 'Long Term Planning Committee' consisting of expertise groups. The Committee and the Ministry of Science and Technology in 1986 created 'Science and Technology Development Long-Term Plan for the 2000s (1987-2001)' in collaboration with other stakeholders. This Plan established the brand goal of accomplishing 'Science and Technology-advanced Korea' by ranking in the world's top ten by the year 2000. In particular, it aimed to position itself as the world leader in high-technology products, and contribute to the growth of GNP, export, and social equity, which were all advanced and concretized in the sixth FYP (1987-1991) and the New Economy FYP (1993-97). These especially expected that industrialized countries would intensify the development of high-tech and knowledge-intensive industries through the 1990s and that there would be an accelerating and strengthening international collaboration between industrialized countries and NICs for competitive industrial development. 


\subsection{DEVELOPING A KOREA-BRAND STRATEGY (D-KBS)}

In line with the Five-Year Plans (FYPs) (Table 42) corresponding to its national development strategy, the Korean Government established national strategic directions in order to accomplish 'Jarip-Gyongje' and sustain 'Jarip-Soungjang.'

Throughout the first and third FYPs, strategic directions for the sustainable development of Korea rested primarily upon two basic notions: developing the industries in order to satisfy the basic needs of the Koreans and constructing infrastructure in order to facilitate more industrialization. Based on these two principles, the Korean Government identified the promotion of export, science, technology and industry (i.e. the principal industries for energy sources and production system) in the first and second FYPs. The third FYP invigorated advancing industrialization by focusing on HCIs, expanding the educational system, developing export clusters, improving the quality of life, and increasing employment. In the fourth FYP, investment capital and social welfare were considered along with promoting industry, exports, and science and technology. Coming to 1980s, the fifth FYP deeply reflected the change of market environment and reinforced trade promotion-encompassing import liberalization as well as export promotion. Through the sixth FYP, improving economic, social and regional equities were described. Restructuring the government functions was also a priority. Along with restructuring the industrial sector and promoting a market economy, promoting science and technology was strongly emphasized in the sixth Plan. As the final FYP, the New Economy Plan (1993-97) placed special emphasis on establishing both internationalization and industrialization and, in particular, encouraged enterprises to be both initiative toward global investment and creative on the basis of design activity.

Table 42 Main strategic directions in the Five-Year Plans

\begin{tabular}{|c|l|}
\hline & -Expanding agriculture production \\
The first FYP & -Constructing infrastructure for expansion of social overhead capital \\
$(1962-1966)$ & -Developing principal sectors for energy sources such as electric power, chemicals \\
& -Developing natural resources \\
& -Improving trade balance by promoting export \\
& -Promoting science and technology \\
\hline & -Securing self-sustaining food system \\
& -Developing natural resources \\
The second FYP & -Developing production system for chemical, steel, and engineering industry \\
$(1967-1971)$ & -Improving trade balance by export expansion and import substitution \\
& -Promoting family planning \\
& -Diversifying agriculture and improving agrarian household income \\
& -Promoting science and technology \\
\end{tabular}




\begin{tabular}{|c|c|}
\hline $\begin{array}{c}\text { The third FYP } \\
(1972-76)\end{array}$ & $\begin{array}{l}\text {-Expanding agriculture production and mechanized farming } \\
\text {-Expanding infrastructure for regions } \\
\text {-Accomplishing US } \$ 3.5 \text { billion for export } \\
\text {-Advancing industrialization with heavy and chemical industries } \\
\text {-Improving employment } \\
\text {-Expanding science \& technology and education system } \\
\text {-Improving regional development by developing export clusters } \\
\text {-Improving quality of life }\end{array}$ \\
\hline $\begin{array}{l}\text { The fourth FYP } \\
\text { (1977-1981) }\end{array}$ & $\begin{array}{l}\text {-Supplying investment capital by Koreans' own ability } \\
\text {-Improving trading balance } \\
\text {-Reinforcing advanced industry structure } \\
\text {-Promoting social welfare } \\
\text {-Innovating science and technology }\end{array}$ \\
\hline $\begin{array}{l}\text { The fifth FYP } \\
\qquad(1982-86) \\
\text { (from Modified } \\
\text { FYP 1984-86) }\end{array}$ & $\begin{array}{l}\text {-Solidifying economic stabilizing system and establishing a base for a self-sustaining } \\
\text { growth } \\
\text { :Stabilizing price system } \\
\text { :Promoting investment on technology and enterprise system } \\
\text { :Increasing export amount prominently } \\
\text {-Reducing technology and competitiveness gaps with advanced countries } \\
\text { :Promoting market competition for enterprise environment based on autonomy and } \\
\text { creativity } \\
\text { :Intensifying technology innovation } \\
\text { :Strengthening enterprise competitiveness by promoting product parts industry of } \\
\text { SMEs } \\
\text { :Increasing agricultural productivity } \\
\text { :Strengthening efficient energy consumption in all industries } \\
\text { :Reinforcing cooperative relationship for science and technology transfer } \\
\text {-Expanding social infrastructure and social development } \\
\text { :Promoting regional development } \\
\text { :Developing social welfare system } \\
\text { :Establishing social inclusion } \\
\text {-Developing government structure }\end{array}$ \\
\hline $\begin{array}{l}\text { The sixth FYP } \\
\text { (1987-91) } \\
\text { (from Modified } \\
\text { FYP in 1988) }\end{array}$ & $\begin{array}{l}\text {-Strengthening enterprise development based on autonomy and economic inclusion } \\
\text { :Promoting enterprises' collaborating relationships } \\
\text { :Restricting enterprise inequality } \\
\text { :Maintaining optimal growth by employment expansion } \\
\text { :Reinforcing high-tech and knowledge-based industry development } \\
\text {-Strengthening social inclusion } \\
\text { :Developing a balanced improvement for regional areas } \\
\text { :Promoting industry development based on regional areas } \\
\text {-Promoting economic openness and globalization } \\
\text { :Reinforcing export industry structure } \\
\text { :Diversifying export markets } \\
\text { :Accelerating international openness and internationalization } \\
\text { :Expanding import and international cooperation } \\
\text { :Promoting foreign direct investment of domestic enterprises }\end{array}$ \\
\hline
\end{tabular}




\begin{tabular}{|c|l|}
\hline & -Reinforcing growth potentiality based on science, technology and creativity \\
New Economy & -Expanding export markets through enterprises initiatives and economic cooperation \\
FYP & with developing nations \\
$(1993-1997)$ & -Improving quality-of-life \\
& -Innovating finances regulation \\
& -Relieving regulation for foreign investors \\
& -Enhancing competitiveness for domestic and foreign enterprises \\
\hline
\end{tabular}

(Source: Kang, 2000; KOTRA, 1992; The Five-Year Plans)

In relation to the nation brand goals for brand visions, i.e. 'Export Korea', 'Science \& Technology-advanced Korea' and 'Industrialized Korea', the Korean FYPs emphasized and maintained strategic concepts of branding export, science, technology and industrial development (i.e. ESTI-brand strategy). These were all legislated by laws and envisaged by promoting programmes or plans.

\subsubsection{D-KBS: ESTI-I (1962-1971)}

With the enactment of the promotion law in 1962, the Government in 1964 selected its 'Export-First Principles' and focused on an export-promoting industrialization strategy in place of its import-substitution industrialization strategy. Placing the first priority on building an export promotion strategy (EPS), the Government envisaged that industrial promotion strategy (IPS) and science and technology promotion strategy (STPS) would be coherent with EPS. In 1960s, EPS was directed to establish a base of export industries, to expand financial supportive measures for export enterprises and their industry development, and to strengthen the exploitation of export markets. Highlighting the imperatives in establishing science and technological infrastructure for industry and export promotions, the Government in 1962 created the first Science and Technology Promotion 5-Year Plan (STPP) along with the first FYP. The first STPP, like the science and technology promotion strategy (STPS), emphasized science and technology being connected to industrial development. Under its main strategic direction, it highlighted law reform, education and training systems in science and technology, international technology cooperation, and the quality of science and technology to international standards. The second STPP advocated the necessity of STPS to be established as the base for Korea's long-term science and technology development and stressed the need to extend science and technology performance into reinforcing export promotion as well as contributing to an increase in industrial products' quality. Moreover, it encouraged collaboration with foreign institutions and attracting them in order to introduce Korea to their advanced science and technology skills. The industrial promotion strategy (IPS) in the early 1960s focused on establishing the infrastructure for industrialization and building import-substitution industries. In line with the 'Export-First Principles', IPS transformd industrial development from import-substitution industries to export-promotion industries. 
Table 43 Strategic directions of ESTI Promotions (ESTI-I)

\begin{tabular}{|c|l|}
\hline & -Applying export liability \\
& -Securing free trade by prohibiting protective trade and regulating a tariff \\
& rate \\
Export Promotion Strategy & -Modernizing export and import system \\
& -Establishing a base of export industry \\
& -Expanding financial supportive measures \\
& -Strengthening to exploit export markets \\
& -Reinforcing trade diplomacy \\
\hline \multirow{5}{*}{ Science and Technology } & -Expanding the science and technology-oriented human resources \\
Promotion Strategy & -Promoting research and development \\
(STPS) & -Investing in human resources and R \& D \\
& -Attracting and managing the foreign sources of science and technology \\
& -Promoting collaborative relationships with foreign institutions \\
& -Improving the quality of the science and technology level \\
\hline Industry Promotion Strategy & -Establishing the infrastructure for industrialization \\
(IPS) & -Building import-substitution industries \\
& -Developing export-promotion industries \\
\hline
\end{tabular}

\subsubsection{D-KBS: ESTI-II (1972-1981)}

The ESTI-brand strategy was further reinforced. The 10-year export plan (EP), as the first long-term EPS, was published in 1970, and presented strategic directions supporting capital investment in production facilities on the one hand and reinforcing export competitiveness in terms of better price and high-quality in export products, market expansion, regulation improvement, and managerial improvements in enterprises on the other hand. Two years later, the Government presented its '10 Billion Export Plan (10BEP)' in line with upgrading export promotion, which was already reinvigorating EPS. The 10B-EP emphasized the building of a national economic policy for export competitiveness, expanding and reinforcing export industries, innovation in technology, expanding export markets, improving export regulations and laws, creating and maintaining special accounts for export promotion, promoting general trading companies, and establishing an "umbrella" exporting company for all SMEs. The third STPP focused on improving industrial technology through the new technology by exploiting the nation's skills and reinforcing international competitiveness. The fourth STPP highlighted innovation in technology, corresponding to the active developments in industry technology, the efficient introduction of advanced technology, the promotion of fundamental science, the development of atomic energy, the promotion of information and systems industries, and the improvement in industrial efficiency. IPS advanced the modernization of industrial structures, which was envisaged concretely by passing the promotion laws and developing medium and long-term promotion plans for the heavy and chemical industries (HCIs). Identifying strategic industries which focused on HCIs, the Government decided to position HCIs as national brands representing high quality and the superior advantage of Korean industries in export 
markets. The President, through his New Year address in 1973, announced strategic directions for building HCIs. Technology-based HCIs, along with securing human resources and skills in science and technology, were mainly highlighted.

Table 44 Strategic directions of ESTI Promotions (ESTI-II)

\begin{tabular}{|c|c|}
\hline $\begin{array}{l}\text { Export Promotion Strategy } \\
\text { (EPS) }\end{array}$ & $\begin{array}{l}\text {-Managing fiscal, monetary and exchange rate policy in organic manner } \\
\text {-Expanding export industry \& products } \\
\text {-Diversifying export markets } \\
\text {-Improving export supporting system } \\
\text {-Creating and maintaining special accounts for export promotion } \\
\text {-Promoting general trading company } \\
\text {-Establishing an exporting company taking full charge of SMEs } \\
\text {-Improving the rate of export net earning and the product quality }\end{array}$ \\
\hline $\begin{array}{c}\text { Science and Technology } \\
\text { Promotion Strategy } \\
\text { (STPS) }\end{array}$ & $\begin{array}{l}\text {-Establishing and improving infrastructure of science and technology } \\
\text {-Promoting industrial technology for HCIs } \\
\text {-Expanding quality improvement in human resources and R\&D } \\
\text {-Promoting knowledge-intensive industry and technology innovation }\end{array}$ \\
\hline $\begin{array}{l}\text { Industry Promotion Strategy } \\
\text { (IPS) }\end{array}$ & $\begin{array}{l}\text {-Reinforcing international competitiveness of export industry } \\
\text {-Promoting HCIs as strategic export industries in an attempt to practice } \\
\text { economics of scale } \\
\text {-Securing engineers and skilled workers } \\
\text {-Promoting the technological aspects of the HCIs } \\
\text {-Selecting the optimal location for the purpose of promoting HCIs }\end{array}$ \\
\hline
\end{tabular}

\subsubsection{D-KBS: ESTI-III (1982-1997)}

Responding to the shift in market environment in 1980s, EPS comprehensively approached not only the trading of products but also building diplomatic relationships with other trading nations. In line with trends of liberalization and internationalization, EPS entailed diversifying export markets into segmentation, building diplomatic relationships with segmented markets, enlarging import liberalization, dealing with import restrictions, and reforming trade regulations and law. Responding to the shift in the international environment, the fifth STPP (1984-1986) clarified that STPS was established in line with EPS and IPS, and especially emphasized setting up a national science \& technology-led policy. Moreover, in order to establish a "Science and Technology Korea," it advanced innovating industry technology and SMEs' science and technology capabilities. Through the 'Science and Technology Development Long-Term Plan for 2000s' and the sixth STPP, the STPS firmly established a strong will to brand a 'Technology-advanced Korea.' Building on the development of HCIs in 1970s, the IPS in 1980s emphasized upgrading HCIs by restructuring enterprises and industries. EPS and IPS focused on exporting 'whole-industries based on HCIs'. 
Table 45 Strategic directions of ESTI Promotions in 1980s (ESTI-III)

\begin{tabular}{|c|c|c|}
\hline $\begin{array}{l}\text { Export Promotion } \\
\text { Strategy (EPS) }\end{array}$ & \multicolumn{2}{|c|}{$\begin{array}{l}\text {-Diversifying with Segmented Markets } \\
\text {-Comprehensively Programming to Import Restriction } \\
\text {-Building trade diplomatic relationships with segmented markets } \\
\text {-Accelerating import liberalization } \\
\text {-Improving trading regulations and laws as international standard }\end{array}$} \\
\hline \multirow{3}{*}{$\begin{array}{c}\text { Science and } \\
\text { Technology } \\
\text { Promotion } \\
\text { Strategy (STPS) }\end{array}$} & $\begin{array}{l}\text { The } 5^{\text {th }} \text { STPS: } \\
\text { (1984-1986) }\end{array}$ & $\begin{array}{l}\text {-Assembling national technology capability for productive R\&D } \\
\text {-Accomplishing the original and vital technology } \\
\text {-Intensively developing the primary strategic-technology and } \\
\text { challenging to develop an advanced technology } \\
\text {-Expanding investment in science and technology } \\
\text {-Promoting highly educated human resources }\end{array}$ \\
\hline & $\begin{array}{l}\text { 'Science and } \\
\text { Technology } \\
\text { Development } \\
\text { Long-Term } \\
\text { Plan for 2000s' } \\
\text { (1987-2001) }\end{array}$ & $\begin{array}{l}\text {-Improving and reinforcing science and technology policy with } \\
\text { consistency } \\
\text {-Improving technology development support system } \\
\text {-Establishing infrastructure in science and technology } \\
\text {-Promoting and securing human resources } \\
\text {-Strengthening quality of education } \\
\text {-Maximizing the application of human resources }\end{array}$ \\
\hline & $\begin{array}{l}\text { The } 6^{\text {th }} \text { STPS } \\
(1987-1991)\end{array}$ & $\begin{array}{l}\text {-Expanding expenditure on human resources and R\&D } \\
\text {-Harmonizing the development both a core strategic-technology } \\
\text { and general industrial-technology } \\
\text {-Promoting both original technology development and advanced } \\
\text { technology transfer }\end{array}$ \\
\hline $\begin{array}{c}\text { Industry } \\
\text { Promotion } \\
\text { Strategy (IPS) }\end{array}$ & \multicolumn{2}{|c|}{$\begin{array}{l}\text {-Upgrading HCIs for competitive advantage in the markets } \\
\text {-Restructuring HCIs and enterprises } \\
\text {-Localizing machinery, components and industrial materials }\end{array}$} \\
\hline
\end{tabular}

Taking over the strategic directions of 1980s, EPS in 1990s put special attention on expanding export structures with high value-added products and reinforcing overseas marketing infrastructure. The New Economy FYP advocated the reinforcing of independent science and technology skills through technology innovation and enlarging science and technology investment, leading to the establishment of an enterprise-led technology innovation system and the reinforcement of a market-led technology development system. Maintaining the basic strategic notion for HCIs, the Government concentrated on establishing the public and private collaborative system for industrial development, reinforcing international cooperation in industrial development, and supporting enterprises' international strategies. 
Table 46 Strategic directions of ESTI Promotions in 1990s (ESTI-III)

\begin{tabular}{|c|c|}
\hline $\begin{array}{l}\text { Export Promotion Strategy } \\
\text { (EPS) }\end{array}$ & $\begin{array}{l}\text {-Expanding export structure with high value-added products } \\
\text {-Expanding overseas marketing infrastructure } \\
\text {-Innovating trading regulations } \\
\text {-Expanding trading support system }\end{array}$ \\
\hline $\begin{array}{c}\text { Science and Technology } \\
\text { Promotion Strategy } \\
\text { (STPS) }\end{array}$ & $\begin{array}{l}\text {-Reinforcing independent ST skills through technology innovation } \\
\text {-Expanding ST investment } \\
\text {-Establishing an enterprise-led technology innovation system } \\
\text {-Reinforcing a market-led technology development system }\end{array}$ \\
\hline $\begin{array}{l}\text { Industry Promotion Strategy } \\
\text { (IPS) }\end{array}$ & $\begin{array}{l}\text {-Establishing 'industry development system based on collaboration of the } \\
\text { Government and enterprises' } \\
\text {-Reinforcing international cooperation as to industry development } \\
\text {-Supporting enterprises' international strategies } \\
\text {-Innovating operation of industrial policy }\end{array}$ \\
\hline
\end{tabular}

\subsection{OPERATING A KOREA-BRAND STRATEGY (O-KBS)}

The ESTI-brand strategy, i.e. the Korea-brand strategy that integrates EPS, STPS and IPS, was operated along with government policies that articulate and guide the ways of export promotion, science and technology promotion and industry promotion. ESTI-brand promotions (ESTI-P), founded on policy measures, were deployed by restructuring export markets, industries and technology-specific resources.

\subsubsection{O-KBS: ESTI-I (1962-1971)}

ESTI-brand promotions during the first and second FYPs, i.e. ESTI-P (I) (Table 47), began with organizing an export promotion agency and providing supportive incentives for export promotion, developing export products and infrastructure for industry promotion, and expanding human resources and advanced technology for science and technology promotion. Sharing the imperatives to establish an export promotion organization that can assume full charge of export promotion, the Government in April 1962 organized KOTRA (then the Korea Trade Promotion Corporation) as a quasi-government agency under aegis of the Ministry of Commerce and Industry. In 1962, Korea recorded only 69 export products, which were sold to only 33 nations. Major export products included those from labor-intensive industries such as wigs, artificial eyelashes, textiles, and plywood. Opening overseas offices in New York, Hong Kong, Los Angeles and Bangkok in 1962 and dispatching market researchers, KOTRA collected market information such as export promotion policies or legislation in strategic markets such as USA, Europe and South East Asia. Collected information was provided to the Government and export enterprises, which was reflected in identifying and developing export products that can deliver brand value to export markets. To facilitate business sales between export enterprises and foreign buyers, 
KOTRA created an exploitation team and invited foreign buyers to visit Korea. Through exhibitions and Expo, the Korean image of products was communicated to export markets.

Export promotion over this period was intensified through industry promotion. Infrastructure expansion was primarily considered to be a basic attribute of ESTI promotion, and the Government allocated a big portion of government expenditure ${ }^{12}$. During the first and second FYPs, three hydroelectric and three thermal power stations were constructed to supply enough energy. Four express highways were completed in the second FYP. Ulsan and Pohang ports were developed to allow exports from the Ulsan chemical industrial complex and the Pohang steel company, and Incheon port was later added. Selecting thirteen export products that were considered to offer brand value to the market, the Government empowered domestic enterprises to involve themselves in producing selected industries and created massive financial incentives for their export activities.

Export and industry promotion were reinforced by science and technology promotion. In addition to providing financial incentives, the Government concentrated on building the export capabilities of enterprises. To establish enterprises' export capabilities, in particular, the Government's Ministry of Foreign Affairs and Trade actively joined international organizations and built relationships with other countries for attracting science and technology resources. Through the agreement for economic cooperation with Japan in 1965, the Government attracted Japanese investment ${ }^{13}$ in Korea and supported domestic enterprises in adopting advanced technology. Contracting with foreign enterprises through technical agreements or joint ventures, domestic enterprises actively built up their own technological capabilities. Recognizing the necessity of building a research institute that can help enterprises to be technologically advanced for industry promotion, the President and Government initiated to attract Korean scientists working abroad. KIST (Korea Institute of Science and Technology) for R\&D activities was finally created in 1966 through the full of wit and hard work of President Park.

Particularly managing the 'Export Promotion Expansion Meeting' since 1965, the President met government ministers, representatives from exporting companies, financial institutions, shipping companies, and labor union leaders on a monthly basis. In the meetings, they discussed export problems, reviewed export trends by item and country, and included the planning of new products. With any complaints noted, the President resolved them quickly. Because the President had a thorough knowledge of related issues, both the

\footnotetext{
12 The share of public sector of gross domestic investment records $38.1 \%$, while the average annual growth rate of gross domestic investment to GDP is $19.9 \%$, and the share of expenditure for transportation and communication in economic services increases to $36.5 \%$ in 1971 from $21.4 \%$ in 1962

${ }^{13}$ In 1961 and 1962, Matsushita and Sanyo have related to build two transistor radio plants. Toshiba has set up operations for the assembly of semiconductors, consumer electronics products, cassette recorder tapes (CRTs), and CRT parts. NEC and Matsushita formed joint ventures or technical agreements with Goldstar Electric, Samsung Electron Devices, or Anam in Korea during 1960s and 1970s (Bloom, 1992:49-50).
} 
representatives and the ministers had to completely prepare in advance for the meetings. The ESTI-brand was actively promoted by both the national leader and government.

Table 47 ESTI Promotions during the First and Second FYPs: ESTI-P (I)

\begin{tabular}{|c|c|}
\hline $\begin{array}{c}\text { Export } \\
\text { Promotion }\end{array}$ & 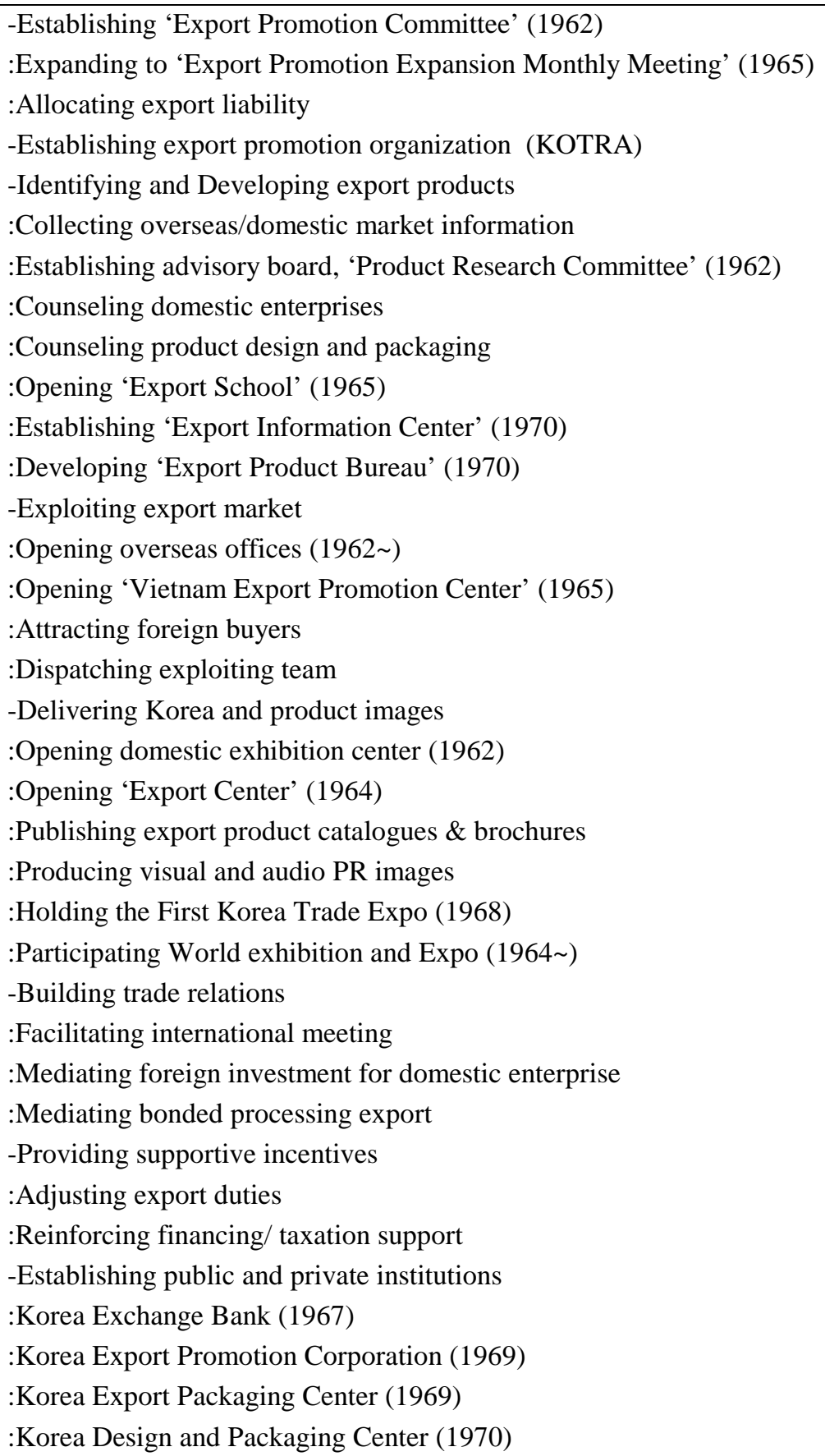 \\
\hline $\begin{array}{c}\text { ST } \\
\text { Promotion }\end{array}$ & $\begin{array}{l}\text {-Collaborating with foreign science and technology } \\
\text { :Joint ventures or technical agreements: Japan, USA } \\
\text {-Establishing resources and skills } \\
\text { :KIST (Korea Institute of Science and Technology) }\end{array}$ \\
\hline
\end{tabular}




\begin{tabular}{|c|l|}
\hline & -Establishing the base of export industry \\
& :Allocating government expenditure \\
& :Developing import-substituting industry \\
& :Developing social infrastructure \\
Industry & :Expanding manufacturing industry \\
Promotion & -Empowering enterprises \\
& :Reducing business income taxes and corporate taxes by 50 percent for export incomes \\
& :Introducing tariff exemptions for materials imported to make products for export \\
& :Providing financial support through low interest loans \\
& $:$ Establishing a firm under the Korea Foreign Trade Association to help small exporters \\
& :Awarding medals and prizes to people contributing to exports
\end{tabular}

\subsubsection{O-KBS: ESTI-II (1972-1981)}

ESTI-brand promotions during 1970s, i.e. ESTI-P (II), (Table 48) were aggregated into operating the HCIs promotion strategy. The Government selected six strategic industries, mainly iron \& steel, petrochemicals, shipbuilding, electronics, nonferrous metals and machinery, for a concerted effort. Pohang Steel Company (POSCO), established in 1968, in 1981 started to supply the increasing domestic demand for crude iron and steel production. The petrochemical complexes in Wulsan and Yochon were built. Kumi Electronic Industry Complex was completed in 1973. To reinforce the international competitiveness of the exporting industries, the Government strategically promoted HCIs by selecting export products from the machinery, electronics and shipbuilding sectors for their comparative advantage and by expanding iron \& steel, nonferrous metals, and petrochemicals sectors in optimal level in line with allied industries. To increase the international competitiveness of enterprises, the Government encouraged enterprises to attract advanced technology and skills from foreign countries, to increase investment for research and development, to improve their management systems in a scientific and rationalized manner, and to improve productivity levels. In line with promoting HCIs and enterprises' competitiveness, national funds were created and supportive incentives, such as subsidies, tax reductions, exemptions and policy loans, were provided. To improve the quality of export products, foreign product designers were invited for design consultations. Free trade areas were constructed in Masan and Iri. Telecommunication facilities were expanded.

Science and technology promotion within ESTI-P (II) was prominently emphasized to drive HCIs' promotion, and aimed to supply specialized human resources to HCIs. Five strategic industrial research institutes in the fields of shipbuilding, machinery, petrochemicals, electronics, and marine science were established to support the technological capabilities. To secure engineers and skilled workers efficiently, the Government categorizes scientific engineers, field workers and technicians. Higher educational institutions (i.e. the Korea Advanced Institute of Science and Technology) were established to cultivate high-level human resources and reinforce research networks among the Government, University, and enterprises. The high-level vocational training 
institutes were reduced into two-year colleges, and the entrance qualification for four-year university courses was adjusted to improve the skills of engineers and technicians in the heavy industries. To expand advanced technology, foreign professionals were hired as researchers or professors to meet the need for $R \& D$ and to better educate the next generation.

KOTRA during ESTI-P (II) proactively exploited new markets for HCIs, mediated trade deals between export enterprises and foreign buyers, and communicated to foreign markets through various specialized channels. Besides consulting services and delegating sales representatives in 1960s, for instance, some special connecting services and touring groups in 1970s were organized. In terms of promoting export products as well as the Korea Image, KOTRA broadly expanded its communication activities and targeted market segmentation in line with strategic priorities. Exhibitions were reinforced through 1970s and PR agents in local area were adopted in order to increase market knowledge. To enhance credible relationships and communication among the Government, export enterprises, foreign buyers and consumers, KOTRA closely collaborated with the overseas offices and the Korean embassies. Since the middle of 1970s, corresponding to trade liberalization, KOTRA concentrated on building cooperative relationships with trade markets and developed a technology and human exchange programme with external stakeholders. Introducing a 'general trading company' by law (1975), the Government provided for enterprises to exploit export markets with their own capacity, but offered supportive incentives.

Table 48 ESTI Promotions during the Third and Fourth FYPs: ESTI-P (II)

\begin{tabular}{|c|c|}
\hline & $\begin{array}{l}\text {-Improving export supporting system } \\
: \text { Creating and maintaining special accounts for export promotion } \\
: \text { Establishing general trading company } \\
\text {-Identifying and Developing export products } \\
\text { :Counseling product design \& packaging } \\
: \text { Promoting plant export } \\
\text {-Expanding export products } \\
: \text { Diversifying \& qualifying light industry products } \\
: \text { Selecting export products (e.g. machinery, electronics, shipbuilding) from HCIs based on } \\
\text { comparable advantage } \\
\text {-Exploiting export market } \\
: \text { Establishing 'Special Market Bureau' (1975) } \\
: \text { Establishing 'Special Trade Service' (1975) } \\
: \text { Opening 'Special Trade Bureau' for Eastern Market (1978) } \\
: \text { Expanding overseas offices } \\
\text {-Diversifying export markets } \\
: \text { Reducing USA market ( } 30 \% \rightarrow 28 \%) \\
: \text { Maintaining Japan market ( } 26 \%) \\
: \text { Expanding EC (17\% } \rightarrow 20 \%) \& \text { Middle East }(6 \% \rightarrow 11 \%)\end{array}$ \\
\hline
\end{tabular}




\begin{tabular}{|c|c|}
\hline (Con't) & $\begin{array}{l}\text {-Delivering Korea \& product images } \\
\text { :Organizing salesmen board } \\
\text { :Expanding domestic exhibitions } \\
\text { :Publishing export product catalogues \& brochures } \\
\text { :Producing visual and audio PR images } \\
\text { :Holding Korea Trade Expo; participating in world exhibitions \& expos } \\
\text {-Building trade relations } \\
: \text { Facilitating international meetings } \\
\text { :Contracting memorandum of understanding (MOU) } \\
: \text { Exchanging human resources and skills } \\
: \text { Hosting symposium for industry cooperation } \\
\text { :Mediating foreign investment for domestic enterprise }\end{array}$ \\
\hline Promotion & $\begin{array}{l}\text {-Developing industry technology in proactive manner } \\
\text { :Researching and developing industry technology development by KIST } \\
\text { :Establishing specialized research institutes (e.g. KAIST) } \\
\text { :Encouraging R\&D by private institutions } \\
\text { :Encouraging technology development by private institutions } \\
\text { :Promoting technology service for plant export } \\
\text {-Collaborating with foreign advanced technology } \\
\text { :Establishing 'technology inducement center' in KIST } \\
\text { :Inviting foreign professionals for education and training }\end{array}$ \\
\hline $\begin{array}{l}\text { Industry } \\
\text { Promotion }\end{array}$ & $\begin{array}{l}\text {-Reinforcing international competitiveness of export industry } \\
\text { :Prioritizing on comparable advantage sources (e.g. machinery, electronics, shipbuilding) } \\
\text { in modernizing HCIs } \\
\text { :Strategically selecting iron \&steel, nonferrous metals, and petrochemicals in optimal } \\
\text { level in line with allied industries } \\
\text {-Expanding international competitiveness of enterprises } \\
\text { :Inducing advanced technology and skills } \\
\text { :Investing in R\&D } \\
\text { :Rationalizing management system } \\
\text { :Increasing productivity level }\end{array}$ \\
\hline
\end{tabular}

\subsubsection{O-KBS: ESTI-III (1982-1997)}

ESTI-brand promotions during the 1980s and 1990s, i.e. ESTI-P (III), (Table 49) concentrated on leaping to a 'Science and Technology-advanced Korea.'

Table 49 ESTI Promotions during the Fifth through New Economy FYPs: ESTI-P (III)

\begin{tabular}{|c|l|}
\hline & -Diversifying with Segmented Markets \\
& :Main surplus-causing market; Main deficit-causing market; Developing market; \\
& Special market \\
Export & -Building trade diplomatic relationships with segmented markets \\
Promotion & -Expanding export structure with high value-added products \\
& -Reinforcing overseas marketing infrastructure \\
& :Expanding overseas exhibitions \\
& :Increasing Korea image PR \\
& -Expanding trading support system \\
\hline
\end{tabular}




\begin{tabular}{|c|c|}
\hline ST Promotion & $\begin{array}{l}\text {-Establishing enterprise-led technology innovation system } \\
\text { :Facilitating enterprises' R\&D institutes } \\
\text { :Reinforcing information service function } \\
\text { :Expanding high-educated researchers } \\
\text { :Expanding tax privilege and technology financing supply } \\
\text { :Relieving regulations } \\
\text { :Expanding national science \& technology facilities } \\
\text { :Establishing enterprise-led partnership among industry, university and research } \\
\text { institute } \\
\text {-Reinforcing market-led technology development system } \\
\text { :Reinforcing technology prediction, research planning and evaluation system } \\
\text { :Facilitating developed new technology to the market } \\
\text { :Revising and reinforcing national research institutes } \\
\text { :Reinforcing collaborative partnerships with technology-advanced countries } \\
\text {-Expanding national R\&D projects } \\
\text { :Expanding investment for R\&D } \\
\text { :Reinforcing industry technology development projects } \\
\text { :Maintaining G7 Project } \\
\text { :Developing a combined technology, atomic energy and aerospace technology } \\
: \text { Expanding fundamental science supporting system for professionals } \\
\text { :Planning technology-combined public systems }\end{array}$ \\
\hline Industry Promotion & $\begin{array}{l}\text {-Promoting industry restructuring } \\
\text { :Restructuring and upgrading HCIs } \\
\text { :Developing high-tech and knowledge-based industry } \\
\text { :Developing factory automation } \\
\text {-Localizing machinery, components and industrial materials } \\
\text {-Restructuring enterprises and supporting their international strategy }\end{array}$ \\
\hline
\end{tabular}

The 'Science and Technology Promotion Expansion Meeting' (STPEM) in 1982 was organized under the supervision of the President. Participating with the Ministers of the Government, politicians, enterprises, academic and research professionals, the meetings looked at technology trends, innovation promotion, strategic promotion for vital technology, and technology support for SMEs. The Technology Promotion Committee was established in 1984 to support and review the STPEM. A special cultivating system for human resources was operated in the Science High School, the Science and Technology University, and in KAIST (Korea Advanced Institute of Science and Technology). The Pohang University of Science and Technology was established in 1986. Through the 1990s, science and technology promotions were operated to focus on enterprise and marketoriented tasks. Enterprises were invigorated to facilitate and innovate their R\&D programmes and expand the number of highly-educated researchers. Moreover, enterpriseled partnerships through close relationships among industry, university and research institute were encouraged, which helped to increase market entry. The Government expanded tax privileges and technology financing supply, and cut down on regulations. Furthermore, by expanding national $R \& D$ projects (such as the $G 7$ project) or investing in 
the development of the future technology, science and technology promotions were proactively operated. In particular, offering significant attention to developing high valueadded industries with science \& technology-driven, the Government enlarged the amount of investment in $\mathrm{R} \& \mathrm{D}$. Moreover, to maintain competitiveness in the markets, enterprises increased tremendously R \& D investment (Table 50).

Table 50 Trends of Korea's research and development investment (Unit: 100million won)

\begin{tabular}{|c|c|c|c|c|c|c|c|}
\hline & $\begin{array}{c}\text { Total R\&D } \\
\text { investment } \\
(\mathrm{A})\end{array}$ & $\begin{array}{c}\text { Government } \\
\text { and public } \\
\text { investments }\end{array}$ & $\begin{array}{c}\text { Enterprises } \\
\text { investments }\end{array}$ & $\begin{array}{c}\text { Government } \\
(\%)\end{array}$ & $\begin{array}{c}\text { Enterprises } \\
(\%)\end{array}$ & GDP (B) & $\begin{array}{c}\text { R\&D } \\
\text { investment } \\
\text { per GDP } \\
\text { (A/B) }\end{array}$ \\
\hline 1981 & 3,688 & 2,036 & 1,652 & - & - & 387,749 & 0.56 \\
\hline 1982 & 5,331 & 2,643 & 2,681 & 50 & 50 & 521,823 & 1.02 \\
\hline 1983 & 6,822 & 2,312 & 4,510 & 34 & 66 & 617,223 & 1.11 \\
\hline 1984 & 9,072 & 2,515 & 6,558 & 28 & 72 & 700,839 & 1.29 \\
\hline 1985 & 12,371 & 3,068 & 9,303 & 25 & 75 & 780,884 & 1.58 \\
\hline 1986 & 16,069 & 3,743 & 12,326 & 23 & 77 & 929,093 & 1.73 \\
\hline 1987 & 19,852 & 4,902 & 14,950 & 25 & 75 & $1,097,265$ & 1.81 \\
\hline 1988 & 24,542 & 5,229 & 19,312 & 21 & 79 & $1,331,342$ & 1.84 \\
\hline 1989 & 28,173 & 5,750 & 22,422 & 20 & 80 & $1,491,647$ & 1.89 \\
\hline 1990 & 33,499 & 6,510 & 26,989 & 19 & 81 & $1,787,968$ & 1.87 \\
\hline 1991 & 41,584 & 8,085 & 33,500 & 19 & 81 & $2,165,109$ & 1.92 \\
\hline 1992 & 49,890 & 8,569 & 41,321 & 17 & 83 & $2,456,996$ & 2.03 \\
\hline 1993 & 61,530 & 10,266 & 51,264 & 17 & 83 & $2,774,965$ & 2.22 \\
\hline 1994 & 78,947 & 18,802 & 60,145 & 24 & 76 & $3,234,071$ & 2.44 \\
\hline 1995 & 94,406 & 22,891 & 71,515 & 24 & 76 & $3,988,377$ & 2.37 \\
\hline 1996 & 108,781 & 28,506 & 80,274 & 26 & 74 & $4,485,964$ & 2.42 \\
\hline 1997 & 121,858 & 33,448 & 88,410 & 27 & 73 & $4,911,348$ & 2.48 \\
\hline
\end{tabular}

(Source: Presidential Advisory Council on Science \& Technology, 2006: 22)

ESTI-brand promotion over the 1980s was directed by pursuing national economic stabilization, which particularly influenced industrial promotion. The rationalization programme was devised in terms of reorganizing and upgrading HCIs sectors and enterprises capabilities, enforcing mergers and acquisitions for specialization in 'promising industries' that needed to increase R \& D or liquidations in 'declining industries' that needed to close. In the early 1980s, reorganizing and upgrading enterprise capabilities, the Government imposed limits on capacity expansion of the large conglomerates (chaebols) who invested in their group families, and forced restructuring of their businesses around the core sectors. While restricting the chaebols' monopolies through strict policy measures, the Government focused on promoting small and medium enterprises (SMEs) and expanded financial incentives and venture support for them in terms that they could more efficiently respond to market needs and increase the national industrial base. Along with restructuring the enterprise system, the Government selected production facilities, the automobile and machinery sectors in order to reorganize HCIs for competitive advantage in their markets. In the middle of this period, the shipping, overseas construction, and fertiliser industries were merged and integrated. Electronics and automobiles with an emphasis on the development of components were categorized as growth-led industries. Industrial 
materials, such as steel and chemicals, were grouped and managed as systematic and high value-added industries. Light industries such as textiles and shoes became engaged more in fashionable and high-value oriented products. Design promotion, in line with creating high value-added industries, was not actively deployed. Throughout the 1980s, it was limited to provide just design information to enterprises. By adopting GD (Good Design) mark certification in selecting well-designed products in 1985, design promotion was reinforced and helped to upgrade competitiveness in export products.

ESTI-brand promotion was proactively reinforced through export promotion corresponding to the change in the market environment. KOTRA intensified market research into segmented markets and held explanatory sessions sharing the information. Furthermore, it solidified its supportive role for the Government to reorganize trade policy toward international organizations. In 1981, HCIs' promotion group was established together with overseas offices to report back with market information on a daily basis. Since 1983, market research for export products of SMEs was intensified. Exploiting export markets for HCIs and SMEs was encouraged and executed. Domestic and international Expos were expanded. Exhibitions for special markets were implemented. Projecting "Korean Products Toward World Class," the Promotion Committee collaborated with the Ministry of Trade and Industry and public organizations was established in 1986 and proactively initiated overseas PR, marketing and design supports for World Class Products. The "Made in Korea Fair' 87" as the biggest overseas PR event was opened in INTEX, Osaka. The U.S. Products Show in 1987 was executed in cooperation with the Government and enterprises from both Korea and USA. Throughout the 1980s and the 1990s, export markets became diversified and segmented by four types, i.e. main surpluscausing market (USA, EC, Canada), main deficit-causing market (Japan, Australia), developing market (Southeast Asia, Middle East, Africa, Central South America), and special market (Eastern Europe, China). Market exploitation was solidified for special markets such as Eastern Europe and the Soviet Union. Overseas networks were expanded to eighty-one including Praha, East Berlin, Beijing, Hochimin and Bucharest and were reinforced as PR centers for the Korea Image. Actively responding to the trade conflicts in industrialized markets, a private trade squad and a regional economic cooperative committee were established. The Ministry of Commerce and Industry changed its name to the Ministry of Trade and Industry. Diplomatic relationships with USA and the EC were strengthened through import liberalization, direct investment and industrial technological cooperation. The Government emphasized a trade policy that represented the Korea Image as taking the initiative and responsibility for the international trade environment and positioning it as playing a major role. 


\subsection{SUSTENANCE OF COMPETITIVENESS OF KOREA}

\subsubsection{National Development Goal \\ Economic and Social Development}

Since the 1960s, Korea has set the national vision of building an "Industrialized Korea on the basis of Jarip-Gyongje" and accomplishing "Jarip-Gyongje based on economic and social development by the early 1980s." Coming up to 1980 s, the national vision was maintained by establishing and sustaining "Jarip-Sungjang as a self-sustaining economic and social development based on stability, autonomy, openness, and creativity." In line with national visions, successive governments have targeted national economic and social development goals, which have been reflected in achievement of macroeconomic outcomes (Table 51). During the first FYP (1962-1966), Korea attained annual national economic growth in GNP of 8 percent, which exceeded the target. Throughout the FYPs (except the $4^{\text {th }}$ FYP which was devoted to restructuring industries and enterprises), national total productivity growth has been increased from 7 percent to 9 per cent. Along with GNP growth, unemployment rates have been recorded at lower rates than those estimated. In 1996, Korea has joined the 10 Thousand-Dollar GDP per capita group and been accepted as a member of the OECD (MOFE \& KDI School, 2006:237).

Table 51 Korea economic and social development: 1960s - 1990s

\begin{tabular}{|c|c|c|c|c|c|c|c|}
\hline & $\begin{array}{c}1^{\text {st }} \text { FYP } \\
(1962-66)\end{array}$ & $\begin{array}{l}2^{\text {nd }} \text { FYP } \\
(1967-71)\end{array}$ & $\begin{array}{l}3^{\text {rd }} \text { FYP } \\
(1972-76)\end{array}$ & $\begin{array}{l}4^{\text {th }} \text { FYP } \\
(1977-81)\end{array}$ & $\begin{array}{c}5^{\text {th }} \text { FYP } \\
(1982-86)\end{array}$ & $\begin{array}{c}6^{\text {th }} \text { FYP } \\
(1987-91)\end{array}$ & $\begin{array}{c}\text { New } \\
\text { Economy } \\
\text { FYP } \\
(1993-97)\end{array}$ \\
\hline $\begin{array}{l}\text { Average GNP } \\
\text { growth rate }(\%) \\
\text { 〔target〕 }\end{array}$ & $\begin{array}{c}8.3 \\
\lfloor 7.1 〕\end{array}$ & $\begin{array}{l}10.5 \\
\lceil 7.0 〕\end{array}$ & $\begin{array}{l}11.0 \\
\lceil 8.6 〕\end{array}$ & $\begin{array}{c}6.2 \\
\lceil 9.2 〕\end{array}$ & $\begin{array}{c}8.7 \\
\lceil 7.6 〕\end{array}$ & $\begin{array}{c}9.4 \\
\lceil 7.3 〕\end{array}$ & $\begin{array}{c}7.5 \\
〔 6.9 〕\end{array}$ \\
\hline $\begin{array}{l}\text { Unemployment } \\
(\%) 〔 \text { target }\end{array}$ & $\begin{array}{c}7.6 \\
\lceil 8.5 〕\end{array}$ & $\begin{array}{c}5.0 \\
\lceil 6.1 〕\end{array}$ & $\begin{array}{c}4.1 \\
\lceil 4.2 〕\end{array}$ & $\begin{array}{c}4.1 \\
\lceil 4.0 〕\end{array}$ & $\begin{array}{c}4.0 \\
\lceil 4.2 〕\end{array}$ & $\begin{array}{c}3.6 \\
\lceil 3.7 〕\end{array}$ & $\begin{array}{l}2.4 \\
\lceil-〕\end{array}$ \\
\hline
\end{tabular}

(Source: MOFE and KDI, 2005; Kang, 2000; KOTRA, 1992)

\section{Human Development Value}

Korea has made every effort to sustain its competitiveness in terms of improving the standard of living for its people. In particular, Korea's national strategy along with the $5^{\text {th }}$ FYP has focused on both social and economic developments. According to the Human Development Index 2005 from the United Nations Development Programme (Fig. 21), Koreans have progressively achieved longer and healthier lives, knowledge, and a decent standard of living. Compared to the human development values of USA in 1970s and 1980s, Korea's human development value remained at a relatively low level. However, 
Korea since the 1990s has been growing to an advanced level and in 2003 approached to the level of well-being in USA.

Fig. 21 Human development value: Korea (1975-2003)

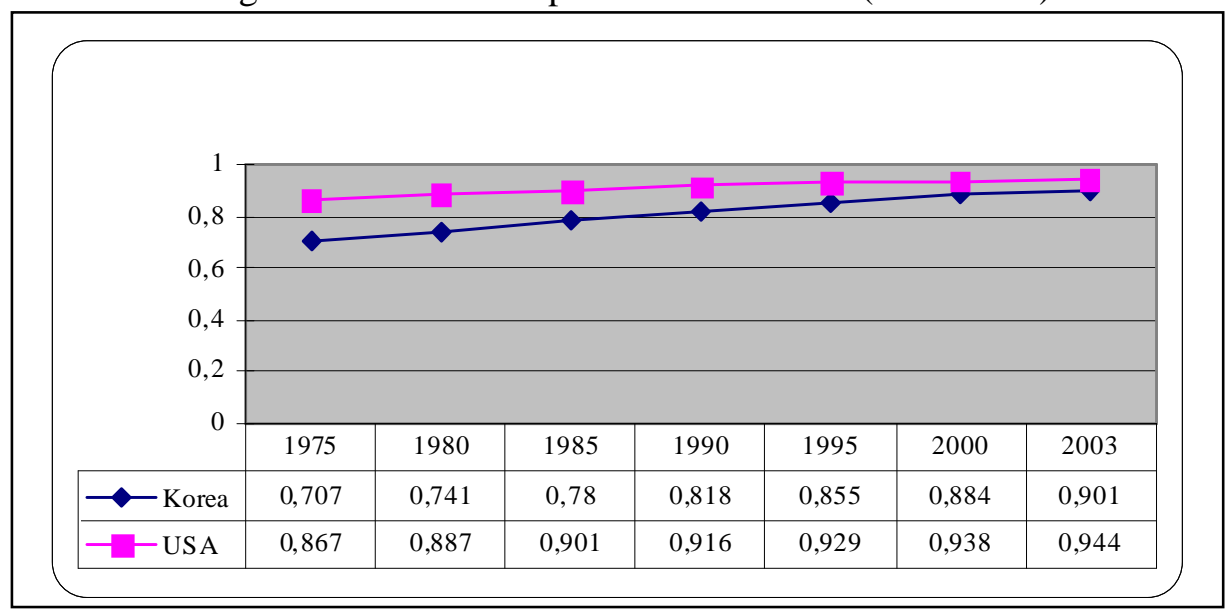

(Source: Human Development Report, HDI 2005)

\subsubsection{Project-based Goal Achievement Export Competitiveness}

Korea throughout the decades has been setting nation brand goals based on ESTI that have targeted 'Export-led Korea' along with building 'HCIs and 'Science and Technologyadvanced Industrialized Korea.' Along with ESTI-brand goals, Korea has achieved greater export competitiveness. According to the Ministry of Commerce, Industry and Energy (MOCIE), Korean exports' share of GDP growth was 34.1 per cent in 1970 and extraordinarily reached more than 110 per cent in 2003 (Table 52). Recollecting the export goal that had set an average amount of US\$140million during the first FYP, over four decades, Korea's export amounts have been growing more than eight thousand-fold, outpacing the national economic growth rate, which have both grown consistently faster than those of the OECD as a whole (MOFE \& KDI School, 2006:237).

Table 52 Korea's exports and its contribution to economic growth

\begin{tabular}{|c|c|c|c|c|}
\hline & $\begin{array}{c}\text { Exports } \\
(\mathrm{US} \$ \mathrm{M})\end{array}$ & $\begin{array}{c}\text { Exports' Contribution to } \\
\text { Economic Growth (A, \% })\end{array}$ & $\begin{array}{c}\text { GDP Growth } \\
(\mathrm{B}, \%)\end{array}$ & $\begin{array}{c}\text { Exports' share in GDP } \\
\text { Growth (A/B, \%) }\end{array}$ \\
\hline 1970 & 835 & 3.0 & 8.8 & 34.1 \\
\hline 1980 & 17,505 & 1.5 & -2.7 & - \\
\hline 1990 & 65,016 & 0.9 & 9.5 & 9.5 \\
\hline 2000 & 172,268 & 2.4 & 8.5 & 28.2 \\
\hline 2003 & 193,817 & 3.4 & 3.1 & 111.2 \\
\hline
\end{tabular}

(Source: MOFE and KDI School, 2006; The Ministry of Commerce, Industry and Energy (MOCIE)) 
Export competitiveness, along with the growth in export volumes, has been built through the profound advancement in export industries and their products. Korea in 1961 relied on an estimated 40 per cent in primary industry such as agricultural and fisheries and 13 per cent in secondary industries, i.e. manufacturing based on light industrial products. Transforming the export industries based on primary industry in 1960s into manufacturing industry and particularly focusing on developing and restructuring HCIs through the 1970s, Korea has secured its strong position with export products on the basis of heavy and chemical industries in export markets. Moreover, throughout the 1980s and 1990s, science and technology-led industries were expanded, which has resulted in reinforcing the export competitiveness that has repositioned Korea as the very competitive nation in HCIs and high-tech industries. Korea's export structure by 2000 has shared a tremendous amount of 80 per cent in HCIs, while the share with primary products has declined to below 3 per cent. By 2004, Korea had accomplished leading positions, particularly becoming the largest shipbuilding nation in the world, the $3^{\text {rd }}$ largest manufacturer of DRAM chips, and the $5^{\text {th }}$ largest producer and exporter of automobiles and steel.

Table 53 Export product structure by major industry groups in Korea (\%)

\begin{tabular}{|c|c|c|c|c|c|}
\hline \multirow{2}{*}{ Year } & Primary & \multirow{2}{*}{$\begin{array}{c}\text { Heavy } \\
\text { Products }\end{array}$} & \& Chemicals & \multicolumn{3}{|c|}{ Light Industry } \\
\cline { 4 - 6 } & 45.4 & 9.2 & 45.4 & 27.7 & 17.7 \\
\hline 1964 & 17.5 & 12.8 & 69.6 & 39.3 & 30.3 \\
\hline 1970 & 11.7 & 41.8 & 46.4 & 29.1 & 17.6 \\
\hline 1980 & 4.9 & 56.6 & 38.5 & 22.7 & 15.8 \\
\hline 1990 & 2.8 & 81.0 & 16.2 & 10.9 & 5.3 \\
\hline
\end{tabular}

(Source: MOFE and KDI School, 2005:141)

\subsubsection{Nation Brand Equity \\ Product Attribute-based Equity}

Competitive positions based on attractive products, particularly from HCIs and hightech industries, have been solidified along with diversification of export markets. Korea in 1962 had limited export markets in 33 nations. Export markets in 1971 included 108 nations, which had extended into new markets such as Eastern Europe as well as other Western markets. Meanwhile, Korea had reinforced its position in USA, Japan and EU markets. Although those Western markets had been imposing trade restrictions in order to protect their domestic markets and expand their exports, Korea maintained export competitiveness in the export markets. In particular, the USA and Japan continued to be Korea's largest export markets, growing from 60 per cent to 70 per cent since the 1960s. According to a 2002 report from KOTRA, export markets were then maintained and diversified over the Chinese territory (24.4\%), North America (21.8\%), Asia and Oceania (15.9\%), the EU (15.5\%), Japan (9.3\%), Middle East and Africa (6.2\%), Central and South America $(5.8 \%)$, and the CIS $(1.1 \%)$. With respect to primary export products and export 
markets (Table 54), Korea exported 65 per cent of its products by volume to ten export markets (USA, China, Japan, Hong Kong, Taiwan, Germany, Singapore, UK, Malaysia and Indonesia). In particular, thirteen products ${ }^{14}$ categorized as a main export product group accounted for over 75 per cent (on the basis of the year 2001) of total exports from Korea. Those export products occupied 63 per cent in only those ten markets. The largest export volume was in the USA market, followed by China and Japan. In particular, semiconductors $(91.2 \%)$, computers $(77.7 \%)$, petrochemicals $(72.0 \%)$ and plastics $(70.6 \%)$ were attractive in these primary markets.

Table 54 Primary export markets and thirteen products' market shares (Year: 2001)

\begin{tabular}{|c|c||c|c|c|}
\hline $\begin{array}{c}\text { Primary } \\
\text { export markets }\end{array}$ & $\begin{array}{c}\text { Amount } \\
(\mathrm{US} \$ 1,000)\end{array}$ & $\begin{array}{c}\text { Thirteen } \\
\text { export products }\end{array}$ & $\begin{array}{c}\text { Export amount } \\
(\mathrm{US} \$ 1,000)\end{array}$ & $\begin{array}{c}\text { Total export market } \\
\text { share }(\%)\end{array}$ \\
\hline USA & $31,210,795$ & Automobile & $7,176,617$ & 53.9 \\
\hline China & $18,190,190$ & IT & $6,438,426$ & 65.3 \\
\hline Japan & $16,505,766$ & Tires & 492,480 & 38.1 \\
\hline Hong Kong & $9,451,678$ & Computers & $8,867,085$ & 78.9 \\
\hline Taiwan & $5,835,269$ & Auto parts & $1,086,734$ & 61.3 \\
\hline Germany & $4,321,766$ & Machinery & $4,412,008$ & 54.8 \\
\hline Singapore & $4,079,605$ & Electronic home & $5,307,747$ & 89.6 \\
\hline UK & $3,489,988$ & Semicondiances & $12,779,028$ & 70.1 \\
\hline Malaysia & $2,628,036$ & Plastics & $1,402,456$ & 72.1 \\
\hline Indonesia & $3,279,783$ & petrochemicals & $6,055,731$ & 59.8 \\
\hline Subtotal & $98,992,876$ & Textiles & $9,561,463$ & 72.8 \\
\hline Total & $150,439,144$ & Iron \& Steel & $5,041,727$ & 21.7 \\
\hline & & Shipbuilding & $2,150,832$ & 63.0 \\
\hline
\end{tabular}

(Source: KOTRA, 2002; KOTIS)

\section{Korea Brand Perception}

In the survey ${ }^{15}$ that evaluates foreign audiences' perceptions of Korea's brand positions in the relevant markets, 'Korea' in general was positioned at the level of advanced countries: between less-developed and advanced countries. With respect to the brand knowledge, 63 per cent of respondents recognized 'Korea' and 93 per cent of them have positively expressed the Korean Image. In terms of brand associations, over 70 per cent of audiences had experienced Korean products and 40 per cent of them have purchased electronic appliances, followed by automobiles and communication products

\footnotetext{
${ }^{14}$ Korean Government has categorized export products and referred to primary export products as thirteen products founded on HCIs and high-tech industries, i.e. Automobile, Auto parts, Computers, Electric home appliances, Machinery, Iron \& Steel, Petrochamicals, Plastics, Semiconductors, Shipbuilding, Textiles, Tires, IT).

${ }^{15}$ The survey has been done on May 10-15, 2002 through KOTRA's 98 overseas networks in 79 countries. Over 10 thousand foreign audiences have responded.
} 
(Fig. 22). In particular, they were more interested in the quality of Korean products rather than the low price relative to products from other countries (KOTRA, 2002).

Fig. 22 Korean products purchased by global markets (Unit: \%)

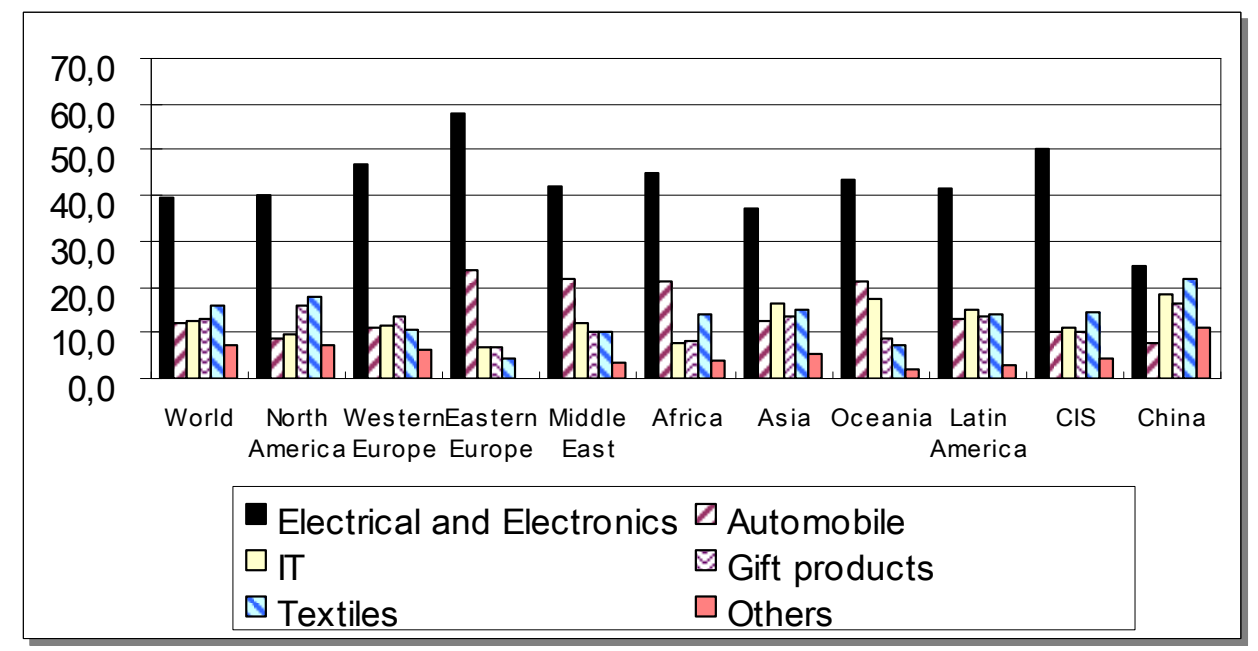

(Source: KOTRA, 2002)

\subsection{CONCLUSIONS}

Korea-branding mechanisms based on a nation-brand system, i.e. ESTI, have encompassed branding actors and activities that have been aligned with Korea's national strategic direction, and have considerably influenced the sustainable competitiveness of Korea.

During the period of ESTI-I (1962-1970), Korea branding took place within a national vision and development strategy. In particular, the President and Government took the initiative and showed entrepreneurship in creating ESTI-brand vision through to operation of the ESTI-brand strategy. Analyzing the national crisis at that time and the competitive advantage offered by a diligent and motivated people, the President and Government created a national vision of building "Industrialized Korea on the basis of 'Jarip-Gyongje' with a self-reliant and independent industrial economy" and of accomplishing 'JaripGyongje' by the early 1980s. To accomplish the national vision, the Korea-brand vision (KBV) was created as building "Industrialized Korea based on Export first Principle." In line with KBV, the Korea-brand goal (KBG) was set up by the Economic Planning Board (EPB). Analyzing branding resources such as industry, science \& technology development and export products on the one hand and branding environment such as an export market, the world economy and international trade volume on the other hand, the EPB in collaboration with other government ministries created the branding objective of building 'Export Korea.' The ESTI-brand strategy for developing and promoting export, science and technology and industry development has been elaborated. It was operated along with 
government policies that supported the restructuring of export markets, science \& technology, and industry-specific resources. KOTRA played a major role in identifying and developing brand attraction in export products and delivering these to primary export markets, collaborating with Korean embassies for attracting foreign advanced science and technology, and distributing the developed skills to other countries.

In the 1970s, Korea was confronted with threats to its national security. Declaring a wish to accomplish 'Jarip-Gyongje,' however, the President and Government created a brand vision of building 'Heavy and Chemical Industrialization' along with the 'Export first Principle.' Analyzing international trade shifts, trade relations with USA and Japan, market competition with the Newly Industrialized Countries (NICs), attractive export products and national industry condition, the Government set both the brand goal and the brand vision. In line with FYPs, the ESTI-brand strategy was elaborated as reinforcing advanced industrial development based on HCIs, developing export clusters, improving the trading balance and innovating science and technology. To promote ESTI, the Government gave policy priority to improving the export support system, creating and maintaining special accounts for financial support and establishing a general trading company in order to facilitate enterprises' export activities. Along with export promotion, moreover, the Government reinforced the international competitiveness of enterprises and export industries by prioritizing to achieve comparative advantage sources (e.g. machinery, electronics, shipbuilding) in HCIs and by strategically selecting iron \& steel, nonferrous metals, and petrochemicals with allied industries. Science and technology promotion was maintained and, in particular, reinforced for HCIs development. Export markets were expanded and diversified within the EC, Middle East and Eastern Europe. Brand communication tools were expanded. Trade relations were reinforced by exchanging human resources and skills. During the period of ESTI-II, in particular, the President and Government took the initiative from vision creation through to operation of the KoreaBrand Strategy. KOTRA has expanded its overseas offices in export markets and played a key role in identifying and developing the brand attractiveness of export products and in communicating this to export markets. During the period, although the national development outcomes were lower than expected despite intensive public investment, the brand goal in terms of HCIs development and export was accomplished.

Coming to 1980s, Korean Government has identified the worldwide technology revolution and analyzed both internal capabilities in science \& technology and external opportunities in emerging markets. The President and Government announced the brand vision of building Korea as an advanced science and technology country and Nordpolitik. Maintaining the national vision of sustaining 'Jarip-Sungjang,' the President and Government during the 1990s announced 'Segyehwa (i.e. globalization). In line with the objective of developing technology-intensive industries and technology-led HCIs, the Ministry of Science and Technology created the brand goal of accomplishing a 'Science and Technology-advanced Korea' ranking in the world top ten by the year 2000 and of 
positioning it as the world leader in high-technology products. Five Year Plans have stressed intensifying technology innovation, strengthening enterprise competitiveness, reinforcing high-tech and knowledge-based industry development, reinforcing export industry structure, diversifying export markets, expanding international cooperation and promoting foreign direct investment of domestic enterprises. In 1990s, the Plans placed the emphasis on growth potentiality based on science, technology and creativity, expanding export markets through enterprises' initiatives and economic cooperation, and increasing competitiveness for domestic enterprises. To promote ESTI, the Government focused on building Korea's image as a country taking responsibility for the international trade environment, and on positioning Korea as a major player with the initiative to trade and cooperate internationally. High value-added products from high-tech industries and HCIs have been highlighted as suitable export products. For science and technology development, enterprise and market-led technology innovation systems have been established. Collaborative partnerships with technologically advanced countries have been reinforced. Export markets have become diversified and segmented. KOTRA has maintained its main responsibility for brand communication. In particular, diplomatic trade relationships have been strengthened as a response to segmented markets.

Korea has achieved successful economic and social developments in terms of economic growth and employment improvement. In terms of ESTI-goals, Korea has achieved export competitiveness, accounting for high growth in export levels and profound increase in exported products. In particular, its competitive position based on attractive products - HCIs and high-tech industries - has been consolidated along with diversification of its export markets. Foreign audiences have perceived Korea positively, based on brand associations with high quality-based products. As well as achieving its repositioning as a competitive nation through attractive products and a good reputation, Korea has improved the standard of living for its people and increasingly built sustainable human development value. 


\section{CHAPTER 6 BRANDING OF IRELAND}

\subsection{BACKGROUND}

Ireland, located in Western Europe, is in a strategic location on major air and sea routes between North America and northern Europe, and is inhabited by above 6 million people. Around 1000-150 B.C., the Celts came over to the island. At the time of conversion to Christianity by St.Patrick (432 AD), the Celts ran Ireland, which enabled them to adopt an affluent Celtic culture. English is predominantly spoken. But, Irish is another language which has been officially recognized by the European Union since June 2005. The Gaeltacht is the legally defined Irish-speaking areas.

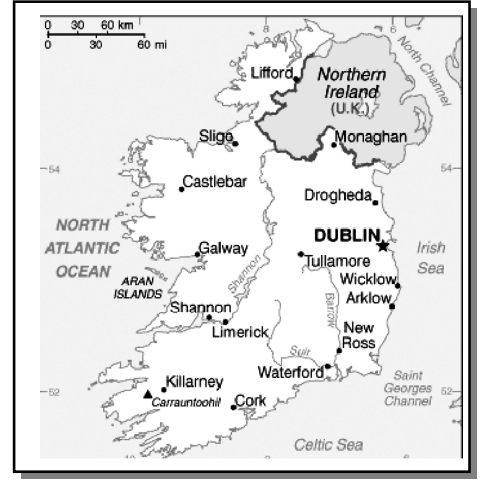

On December 6, 1921, the Irish Free State (1922-1937) was established through the Irish Free State Agreement signed by British and Irish Republic representatives in London, and divided Ireland into two entities: the Irish Free State (covering $80 \%$ of the island's land area) comprising the 26 of Ireland's 32 counties and Northern Ireland (six counties) remaining as part of the UK. In the 1930s, Fianna Fáil, the party of the opponents of the treaty, was elected into government and introduced a new Irish constitution in 1937, which renames the Irish Free State as Ireland (Eire in Gaelic). In 1949, the Republic of Ireland Act, which had been enacted in 1948, officially declared the name Republic of Ireland as the official description of the state and marked its exit from the British Commonwealth.

The Irish economy adopted a protectionist approach to industrial development in the immediate post-independence period (1920-1950s). By the end of the 1950s, Ireland's GDP per head had declined to one of the lowest levels in Europe and emigration reached unprecedented levels, which inevitably made Irish industrial policy change from a protectionist standpoint toward an openness to foreign trade and investment. However, the Irish economy was confronted with a deep recession throughout the late 1970s until the middle of the 1980s.

In the late 1980s, the Irish economy began to improve and later achieved unprecedented economic successes. In 1987, a minority Fianna Fáil government took office and the Prime Minister led the Programme for National Recovery as the national strategy, focusing on 'inward investment' into Ireland and adopting the idea of creating one of world's leading financial hubs in Dublin's Docklands area. Coming to 1990s, Forfás was established as the national policy and advisory board for enterprise, trade, science, technology and innovation, and the coordinater for state bodies. The State's legal powers for FDI, industry, enterprise and knowledge development (FIEK) were vested in Forfás. 
National development strategies were put in place for place development and economic diplomacy. Ireland's economic performance has created a 'Celtic tiger.'

In 1999, Ireland repositioned itself as a European platform for overseas companies. "Ireland, knowledge is in our nature" has been created to feature the Celtic thumbprint symbolizing 'The Irish creative, flexible and knowledge mind.'

\subsection{CASE STUDY DESIGN}

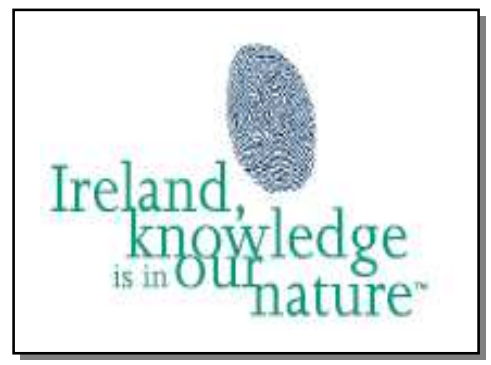

Ireland's image through the middle of 1980s was that of a poor country economically. Concerns about the country's creditworthiness - due to the government's budget deficit had spread to international investors. However, coming into the 2000s Ireland has achieved economic success, which gives it a position among economically successful countries and its reputation as a "Celtic Tiger." To explore how Ireland has achieved its reputation and competitiveness by nation branding, our research observes empirical evidences throughout the nation branding events covered from the middle of 1980s through the early of 2000s.

Since 1987, Ireland built the National Development Programmes (NDPs) as the national strategies. During the periods of NDPs, Ireland created the brand Ireland - a type of FIEK - based on FDI, Industry, Enterprise and Knowledge development. Therefore, this study emphasizes the brand development process with FIEK-brand system and explores branding process of how Ireland's FIEK-brand system has driven a highly innovative country, and repositioning Ireland as the one of the most qualified places for the living.

Based on the key concept of nation branding (2.2.5, p.34-45), the period of NDPs is suitable to investigate the context of a strategic fit between a nation brand and a national strategy. These are allocated to certain episodes in terms of branding actors and their branding activities of developing and managing brand strategy, brand identity and image. The first NDP was from 1987 till 1990, which provided a backbone for creating the FIEKbrand system. During the second period of NDPs (1991-1998), Ireland reinforced it with strategic decisions of national strategies. Coming into 1999, Ireland rebranded itself to be innovative and competitive nation for the $21^{\text {st }}$ century and in 2000 developed a new strategic vision that provided a continnum for envisioning new plans in 2004.

Aiming to identify Ireland-specific branding mechanisms in the FIEK-brand system and contextual patterns in the branding process of the 'Nation Branding Mechanism Model,' this research highlights Ireland branding episodes by three branding encounters as follows:

- FIEK-I: The branding episode period from 1987 to 1990

- FIEK-II: The branding episode period from 1991 to 1998

- FIEK-III: The branding episode period from 1999 to 2003 


\subsection{CREATING AN IRELAND-BRAND VISION (C-IBV)}

\subsubsection{C-IBV: FIEK-I (1987-1990)}

During the period from 1980 to 1985, Ireland faced severe economic and employment difficulties. Demographically, net emigration in the five years to 1986 was estimated at 75,000 , while the 1970s had been characterized by a sustained net inflow of population, at an annual average rate of approximately 9,500.

Since 1973, Ireland's NESC (National Economic and Social Council) has been chaired by the Secretary General of the Department of the Taoiseach (Prime Minister) and composed of representatives of trade unions, employers, farmers' organisations, NGOs, key government departments and independent experts. Becoming conscious of a current national crisis, NESC was concerned that the Irish economy had lapsed into a vicious circle: high national debt led to an incresed tax burden, which in turn resulted in a negative effect on employment and economic activity. Unemployment and the public finances were therefore regarded as the main problems. Meanwhile, the NESC observed that the modern sectors of manufacturing industry, comprising Chemicals, Office Equipment and Instrument Engineering, experienced very rapid growth between 1980 and 1985, and significantly that volume growth (13.4\%) in manufacturing output by sector in 1984 had sharply decelerated to 2.7 per cent in 1985. At the same time, the NESC highlighted that all three sectors in Ireland had been dominated by overseas companies, especially US multinationals. Taking into account the prospects for the 'modern' manufacturing sector in terms of international market environment and the possibility of a 'life-cycle' effect within successive generations of foreign enterprises established in Ireland, the NESC pointed out that sustained economic growth is dependent on a major improvement in competitiveness. Moreover, it anticipated the improvement in competitiveness by the short-term contributions to sustaining employment growth over the longer term. Envisaging economic and social development, in 1986 the NESC ultimately shared a strategic vision of rebuilding Ireland as a cohesive society with sustainable employment growth and an internationally competitive economy.

Charles Haughey, the then leader of the opposition, had received a presentation about the idea setting up an international financial services centre (IFSC) in Dublin, and was impressed with the opportunities for attracting both international finance services enterprises and the talented, young Irish financial services professions who often emigrated. Sharing the recommendations of economic and social development from the NESC, Charles Haughey became confident that development built on the international financial services sector could create a new turn in the economic and fiscal crisis that Ireland faced. Immediately on taking office as Taoiseach (Prime Minister) in 1987, he assigned the secretary of the Taoiseach's department to organize the steering group and appointed chief executives from all the relevant public sectors (the Taoiseach's department, 
Central Bank, the IDA, finance and revenue) along with private sectors (top two banks, KPMG accountants, stock brokering firms and others). In line with the Prime Minister's belief in the IFSC project, the Government and the steering group initiated development of the concept for the IFSC in order to turn the idea into a reality. A brand vision of rebuilding Ireland into a leading world financial services hub was envisaged.

\subsubsection{C-IBV: FIEK-II (1991-1998)}

At the beginning of the 1990s, Ireland's unemployment rate still remained above the EC (European Community) average. Long-term unemployment was among the highest in the OECD. The NESC believed it necessary to put a special focus on resolving long-term unemployment, and was convinced of the critical importance of securing high rates of economic growth as a basis for increasing the rate of employment growth. Meanwhile, in 1992 the Culliton Review Group made recommendations for industrial development of Ireland and suggested strengthening the environment for enterprises. Along with general considerations for improving the enterprise environment, the Review Group particularly pointed out that the degree to which an enterprise undertakes core business functions from an Irish base, rather than simply origin of ownership, should be the critical distinction for policy purposes. In 1993, the Government established Forfás as the national policy and advisory board for enterprise, trade, science, technology and innovation. In 1993, the NESC confirmed that, in order to secure a sufficient condition for competitiveness and employment growth over the medium to long-term, innovation capacity in response to market environment change will be the key to Ireland's success. Sharing the fundamental responsibility for ensuring improved performance, the NESC envisaged a national vision which would be compatible with Irish interests and the need for self-sustained development. Moreover, to achieve employment growth in the global economy, the NESC created a brand vision to sustain long-run competitiveness through enterprise innovation.

\subsubsection{C-IBV: FIEK-III (1999-2003)}

In line with the objective of achieving innovation and competitiveness, at the end of 1990s knowledge was more emphasized as one of the main drivers of prosperity and wellbeing. The Irish Council for Science, Technology and Innovation (ICSTI) ${ }^{16}$ in association with Forfás in 1999 identified information and communication technologies (ICTs) and biotechnology to be the key drivers of technological change worldwide up to 2015 . In particular, Forfás believed that Ireland, as a small open economy, would be more exposed than most economies to changes in the international environment, and reported that Ireland needed to transform rapidly towards a knowledge-based economy based on ICTs and biotechnology, through providing research and development at world-class level.

\footnotetext{
${ }^{16}$ ICSTI publishes Technology Foresight Ireland (TFI) in 1999. This policy document particularly envisages the key importance in developing the industrial development strategy of Ireland.
} 
In 1999, the NESC envisaged a national vision of Ireland sustaining the virtuous circle of achievements in economic and social inclusions into the new century. Given the present economic and social context, the NESC believed that for the next decade Ireland could look forward to building a more dynamic economy and participatory society, incorporating a commitment to social justice and consistent economic development that is socially and environmentally sustainable, and responding especially to the constantly evolving requirements for international competitiveness. In particular, the NESC expected that, over the next decade, a revolution in information and communications technology would be likely to change the face of the global economy and would give rise to enormous changes in economic and social structures in developed economies. Determining how Ireland would be competitive in the early years of the next millennium, the NESC presented a new brand vision which positioned Ireland strategically as a Knowledge-based Society, a World Centre of Research Excellence, based on enterprise's competitiveness and social partnerships. The NESC believed that ultimately this would provide a way to benefit Irish people in the future.

The shared visions were reflected in envisaging a brand vision for the IFSC and Irish enterprise development in the new century. A research report entitled "The Financial Services Industry in Ireland: Challenges and Opportunities in the New Millennium" was prepared by Professor Hutchinson on behalf of the Financial Services Forward Strategy Working Group. This report identified the vital importance of the IFSC as the primary source of employment and business growth in the industry and the need to improve Ireland's competitiveness as a business location through the coherent use of all available policy instruments. Along with the shared vision, the Department of Taoiseach invigorated a brand vision to maximize the level of sustainable economic activity and employment in the international financial services sector in Ireland, encompassing not only the number of jobs but also the quality of employment and activity, and the possibility of improving sustainability of the IFSC through links to related sectors (e.g. shared services, electronic commerce, software development).

\subsection{SETTING AN IRELAND-BRAND GOAL (S-IBG)}

The national vision that was shared by the NESC in 1986 was ultimately to rebuild Ireland as a cohesive society with sustainable employment and competitiveness. Following the strategic and shared vision, the NESC directed Ireland's branding to focus on establishing economic competitiveness over the period from 1987 to 1990, accomplishing self-sustaining development through innovation during the 1990s, and sustaining the virtuous circle of the achievements in economic and social inclusion in the new century. The Government, through concerted efforts with social partners, developed national development programmes and primarily reflected Ireland's vision to envisaging national economic and social development goals (Table 55). 
Table 55 Expected national goals through national development programmes

\begin{tabular}{|l|c|c|c|}
\hline & $1985-1990$ & $1990 \mathrm{~s}$ & $2000-05$ \\
\hline GNP (Annual Growth Rate, \%) & - & $3.5-4$ & $2.5-5.0$ \\
\hline GDP (Annual Growth Rate, \%) & $1.9-3.2$ & $3.6-4.7$ & - \\
\hline Total employment (Annual change, \%) & $-0.7-0.3$ & $9,000-11,000$ (People) & - \\
\hline
\end{tabular}

(Source: NESC, 1999; 1996; 1993; 1986-1990)

\subsubsection{S-IBG: FIEK-I (1987-1990)}

Ireland in 1986 was confronted with national economic and social difficulties. GDP per capita was only 64 per cent of the European Community average. The National Debt was equivalent to more than one and one-half times Ireland's GNP. An unemployment rate of 18.5 per cent of the workforce amounting to 242,000 was one of the highest rates of unemployment in the European Community. Net emigration was estimated at around 30,000 , equivalent to the birthrate. However, despite intense international competition, there was an increased level of investment commitments from new and expanding overseas companies (Table 56). 180 investment projects were approved. Among them, US enterprises remained the largest source of FDI with 77 projects, and there was a striking feature of substantial increase in planned investment from the Far East.

Table 56 Features and source of overseas investment: 1985-1986

\begin{tabular}{|l|c|c|c|c|}
\hline \multicolumn{1}{|c|}{ Investment Projects } & \multicolumn{2}{|c|}{1985} & \multicolumn{2}{c|}{1986} \\
\hline Small Business & No.of Projects & $\begin{array}{c}\text { Fixed Asset } \\
\text { investment (£m) }\end{array}$ & No.of Projects & $\begin{array}{c}\text { Fixed Asset } \\
\text { Investment(£m) }\end{array}$ \\
\hline Mainstream Irish Industry & 685 & 43.0 & 773 & 43.0 \\
\hline Overseas Industry & 101 & 97.8 & 117 & 125.8 \\
\hline -United States & 178 & 260.8 & 180 & 391.6 \\
\hline -Far East & - & - & 77 & 192.5 \\
\hline -West Germany & - & - & 3 & 78.9 \\
\hline -Netherlands & - & - & 7 & 31.9 \\
\hline -Scandinavia & - & - & 15 & 25.7 \\
\hline -UK & - & - & 33 & 17.5 \\
\hline -Other Non-European & - & - & 7 & 18.6 \\
\hline -Other European & - & - & 7 & 5.1 \\
\hline
\end{tabular}

(Source: IDA Annual Reports)

Analyzing the internal problems and the external opportunities for attracting overseas investment, the Government and social partners announced that Ireland's economic and social prospects depended ultimately on the further development of Ireland's industrial base, encompassing both manufacturing and services industries, to produce quality products for world markets. In particular, they expected that the financial services sector would contribute significantly to industrial development. Through the 'Programme for National Recovery (PNR)' (1987-1990), the Government and social partners promoted 
overseas investment (i.e. FDI Promotion) into Ireland's economy, along with a determined approach toward industry development promotion (i.e. IP). Anticipating a combined approach (i.e. FI Promotion) to integrating FDI promotion into Ireland's IP, PNR aimed to create approximately 20,000 extra jobs on average per year over the next ten years and generate almost 16,500 new jobs through FDI promotion in the period of the Programme, in particular, the creation of 7,500 jobs over the next 3-4 years, by attracting international financial services companies, especially through the IFSC project.

\subsubsection{S-IBG: FIEK-II (1991-1998)}

In the 1990s, the Government critically intended to deepen the competitiveness of the Irish economy, to accomplish self-sustaining development. According to the NESC report 'A Strategy for Competitiveness, Growth and Employment (1993),' the share of employment in various service categories in Ireland had been comparably lower than that of other small countries with lower unemployment. Over the period from 1973 to 1990, the average annual rate of growth of total services employment in Ireland had been 1.7 per cent, which placed Ireland as the fourteenth out of the sixteen OECD countries (Table 57). Moreover, the NESC report pointed out that small countries had managed to establish very significant market niches for some types of services and that there had been evidence of the growing share of services in the flows of foreign direct investment.

Table 57 Employment in services (Average annual rate of employment growth, \%)

\begin{tabular}{|c|c|c|c|}
\hline & $1973-90$ & $1973-79$ & $1979-1990$ \\
\hline US & 2.7 & 3.2 & 2.4 \\
\hline Japan & 2.1 & 2.2 & 2.0 \\
\hline Sweden & 2.0 & 2.9 & 1.5 \\
\hline Denmark & 2.0 & - & 1.7 \\
\hline UK & 1.8 & 1.4 & 2.0 \\
\hline Ireland & 1.7 & 2.7 & 1.2 \\
\hline EC & 2.0 & 1.8 & 2.1 \\
\hline OECD & 2.4 & 2.5 & 2.3 \\
\hline Note. Countries are ranked on the basis of employment performance, 1973-1990 \\
\hline
\end{tabular}

(Source: NESC, 1993:332; OECD Historical Statistics, 1960-1990)

Advancing the 'Programme for Competitiveness and Work (PCW)' for the period 1994 to 1999, the Government and social partners pointed out that the successful conclusion of the GATT negotiations should provide a significant boost to growth in the world economy over time but that the short run outlook for economic recovery in a number of Ireland's main markets was slow and uncertain, but that what was certain was that the degree of competition to which Irish producers would be exposed would increase both in overseas markets and at home. Consequently, the PCW emphasized sustainable employment and enterprises in terms of both market-led growth and community-based 
work. To meet the challenges, it set the target for inward investment to achieve 9,000 gross jobs per annum on average over the period of the Programme.

Functioning as the body in which Ireland's legal powers for industrial promotion and technology development have been vested, Forfás in 1995 carried out a survey corresponding to an annual census of employment in all known active manufacturing and internationally traded service companies. According to that survey, employment in foreignowned manufacturing companies over the past 10 years had displayed consistent growth. In particular, permanent full-time employment in foreign-owned internationally traded and international financial service sectors had increased (Fig. 23).

Fig. 23 Internationally traded and international financial services employment: 1986-1995

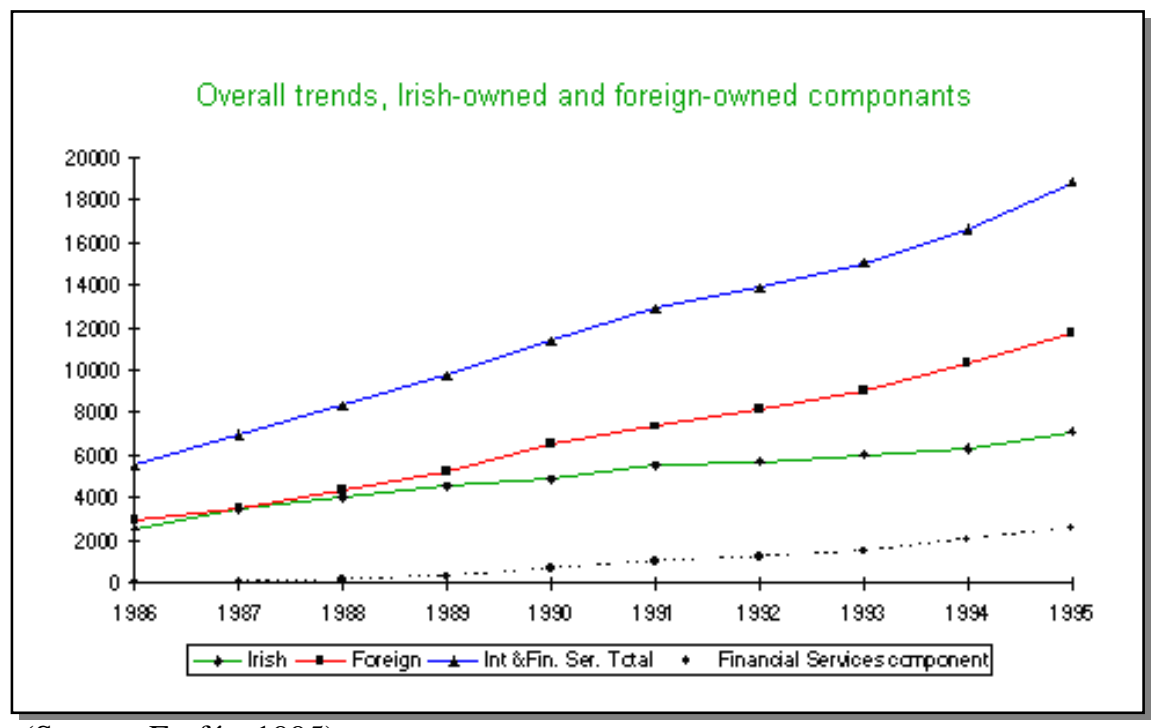

(Source: Forfás, 1995)

Identifying that trade was increasingly linked to foreign direct investment (FDI) and that the trend in FDI was a matter of considerable importance to Ireland, Forfás highlighted that attracting FDI would remain fairly competitive within European economies, involving developed nations such as Germany, France, Denmark, Netherlands as well as central and Eastern European countries. To achieve the national economic and social objectives, it was imperative to consider that the changing nature of the FDI market would bring additional competitive pressures on Ireland's position over the next decade and beyond. Therefore, Forfás insisted that a vibrant and competitive enterprise sector (i.e. the set of Irish-owned and foreign-owned enterprises, based in Ireland, engaged in either the manufacture of goods or the provision of marketable services) is crucial. Integrating Irish-owned and foreign-owned enterprises into a concept of an enterprise sector, Forfás contemplated an approach to FI (FDI \& Industry) promotion focusing on enterprise development. To attain a self-sustaining basis for the 2000s, in 1996 Forfás presented a long-term framework for enterprise development promotion (i.e. EP) over the next fifteen years. It aimed to reduce the number of unemployed from 127,000 in 1995 to no more than 50,000 by 2010, increase 
living standards, in terms of GNP per capita, to achieve average EU-15 levels, compared with 65.2 per cent of the EU-15 average in 1995, and raise the quality of life of all of those living in Ireland.

\subsubsection{S-IBG: FIEK-III (1999-2003)}

Forfás, through its 'Enterprise 2010' report, reinforced the targeted growth output for 2010 and analyzed global conditions that deeply affected the Irish economy. In the report, technological change worldwide was mainly referred to as a long-term trend, especially focusing on the ICT sector (Fig. 24). In particular, electronic business was considered as one of the most significant drivers of both successful business development and national economic development, offering a new route to addressing some of Ireland's strategic challenges and major new business opportunities for Irish-based enterprises and for the development of new sectors. At the same time, Forfás expected that such e-business would facilitate the flow of mobile service industry projects between developed countries and the execution of lower value-added projects in low-wage countries, which would affect enterprises' location decisions and further intensify the competition for FDI.

Fig. 24 Key trends in information, telecommunications and computing industries

\begin{tabular}{|l|l|l|}
\hline Network-based services & $\begin{array}{c}\text { Growth of } \\
\text { data networking }\end{array}$ \\
\hline New computing devices & Software \& server architectures \\
\hline
\end{tabular}

(Source: Forfás, 2000: 14)

Analyzing employment, output and productivity of the enterprise sector in Ireland, meanwhile, Forfás noticed the sectoral gap between Irish-owned and foreign-owned manufacturing sectors. Overall, Irish-owned industry had a relatively limited presence in the high-technology sectors. Productivity in the foreign-owned manufacturing sector had underpinned the competitiveness of the segment, in particular highlighting that sectoral concentration had increased in the higher technology sectors over recent years. Forfás emphasized that increased productivity was the fundamental basis for the sustainable competitiveness of enterprises and for stable high-income employment. Forfás anticipated that productivity growth would have to come from both shifts in employment toward higher value-added activities and through increasing the productivity of existing employees in all sectors of the economy. In line with the objective of increasing productivity, Forfás aimed to establish the conditions under which a higher proportion of foreign companies' value-added activities would be carried out in Ireland and to create additional higher valueadded jobs in the internationally-traded sector (manufacturing and internationally traded services) from 310,000 in 1998 to 400,000 in 2010. 
Aiming to sustain the virtuous circle of achievements in the Irish economic and social inclusion in the 2000s, the Ireland-Brand Goal was furthermore envisaged with respect to the development of the international financial services (IFS) industry. Reflecting the IFSC project over 1990s, the Government asserted that the next five years would be critical to the long-term viability of the IFS industry in Ireland in terms of the transition of the tax regime and uncertainty about the authorities' attitudes to any future development. Also, there was the challenge to ensure that the IFS industry would continue to flourish in terms of the quality and quantity of employment and activity. The Department of the Taoiseach was fully aware that the challenge facing the industry itself was to maintain its competitive edge at a time of rapid economic, legislative and regulatory change. To sustain the competitiveness of the IFS industry in Ireland, the Government formulated tasks in building the positive "image" of the IFSC and promoting Ireland as an excellent financial services location.

\subsection{DEVELOPING AN IRELAND-BRAND STRATEGY (D-IBS)}

In October 1987, the Government and the social partners negotiated how Ireland could regenerate its national economy and improve employment, ultimately achieving improved social cohesion. Adopting the vision and goals of 'A Strategy for Development 1986-1990' envisioned by the NESC, they envisaged the 'Programme for National Recovery (PNR)' amounting to a national development strategy. The new concerted efforts consecutively generated the 'Programme for Economic and Social Progress (PESP)' in 1991, the 'Programme for Competitiveness and Work (PCW)' in 1994 and 'Partnership 2000 (P2000)' in 1996. These Programmes presented strategic directions for the economic and social developments of Ireland.

Confronting Ireland's fiscal crisis, PNR (Table 58) represented a major attempt to overcome the serious obstacles that then existed to impede economic and social development. As the emerging priority, PNR focused on stabilizing macroeconomic conditions on the one hand and reinforcing industrial development in line with employment improvement on the other. Articulating a sector-by-sector approach for industry development promotion (IP), PNR emphasized that FDI Promotion in Ireland be intensified on a specialized basis, integrating such investments into the Irish economy. In particular, the Programme articulated the project that was to create the International Financial Services Center (IFSC) in Dublin. 
Table 58 Main strategic directions in Programme for National Recovery (PNR)

-Stabilizing macroeconomic conditions

-Reforming tax system

-Diminshing social inequities

-Generating job opportunities on a sectoral basis

:Reinforcing industrial development promotion

:Intensifying FDI promotion on a specialized basis

(Source: Programme for National Recovery, 1987)

Coming to the 1990s, the 'Programme for Economic and Social Progress (PESP)' was established in 1991. In the context of reducing long-term unemployment as the primary strategic intent, PESP (Table 59) reinforced industry development promotion (IP) by focusing on the development of an internationally competitive industry, in particular through the manufacturing and international services sectors. It articulated macroeconomic policies, infrastructural services, and specific programmes and incentives aimed at maximizing the employment and economic benefits of industrial development. To attract industry to Ireland, PESP pointed out that the Government would continue to seek to maximize the extent of economic activity by overseas companies to obtain the benefits of both direct and indirect jobs in the Irish economy and would target the main industrial subsectors, such as electronics, engineering, software and financial services sectors.

Table 59 Main strategic directions in Programme for Economic and Social Progress (PESP)

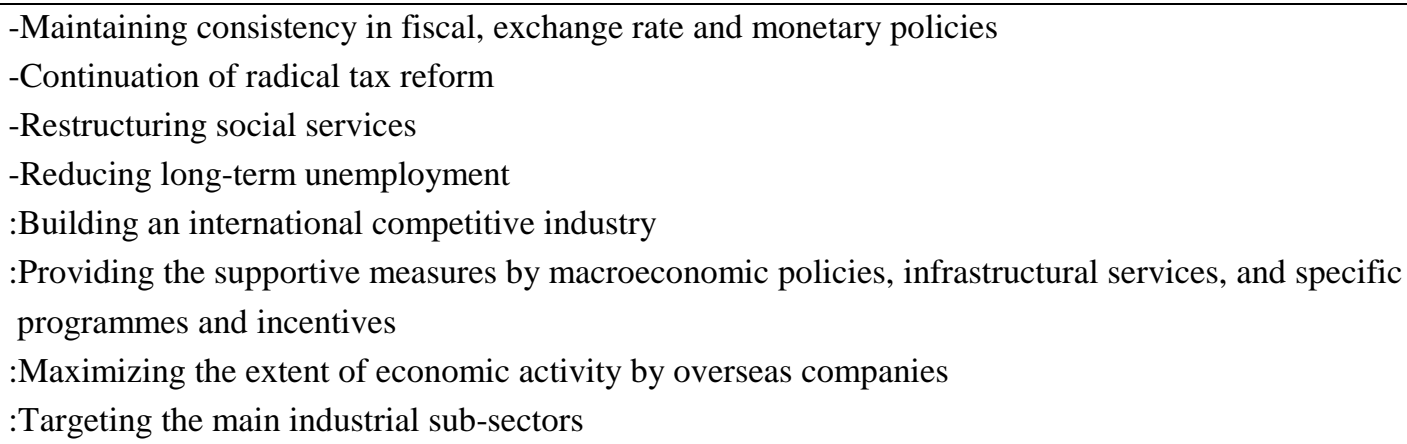

(Source: Programme for Economic and Social Progress, 1991)

The Government, through its shared concern, in 1994 presented the 'Programme for Competitiveness and Work (PCW)' to deepen the competitiveness of the Irish economy. The key challenge in PCW (Table 60) for the period from 1994 to 1996 was to increase the number of people to work within the Irish economy and so to reduce the level of unemployment. To meet this challenge, it primarily developed the National Development Plan, targeted policy changes improving employment performance, consistent fiscal policies, and a partnership framework. Within the framework, in particular, PCW put the emphasis on two components: sustainable employment and enterprise, based on market-led growth and community-based work. PCW articulated that the focus of strategy for the 
promotion of inward investment under the National Development Plan 1994-1999 would be to concentrate on the key sectors and market niches in which Ireland enjoys the greatest competitive advantage. Moreover, it set the inward investment sub-programmes that comprised a measure targeted at the further integration into the Irish economy of overseasowned firms already located in Ireland as well as measures directed at attracting internationally mobile investments to generate new job opportunities and to inject new skills and new technologies into the Irish economy. For IFSC promotion, PCW pursued a policy of creating an attractive and efficient infrastructure, establishing a competitive and stable business environment and promoting the development of new business.

Table 60 Main strategic directions in Programme for Competitiveness and Work (PCW)

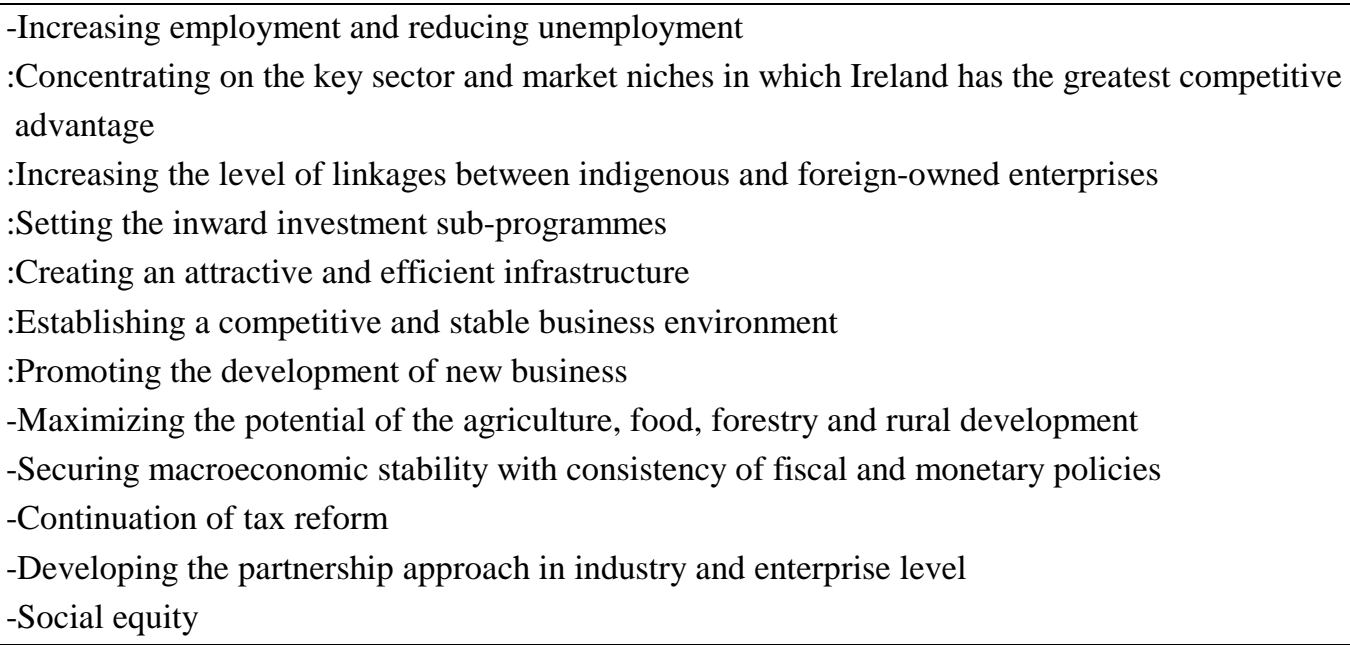

'Partnership 2000 (P2000)' (Table 61) was created in 1996 to extend partnership arrangements at the enterprise level, articulating supportive measures through the national macroeconomic framework. In particular, the Government and social partners agreed that sustaining national economic competitiveness was linked to developing an enterprise environment. To improve enterprise competitiveness, moreover, P2000 aimed to maintain continuous innovation in terms of technology and its application within firms, to develop high-skilled workers and life-long learning in all work roles, to focus on specific sectoral strategies in the key developmental and modern infrastructural areas, to promote enterprise and new business formation, and to promote exports. 
Table 61 Main Strategic directions in Partnership 2000

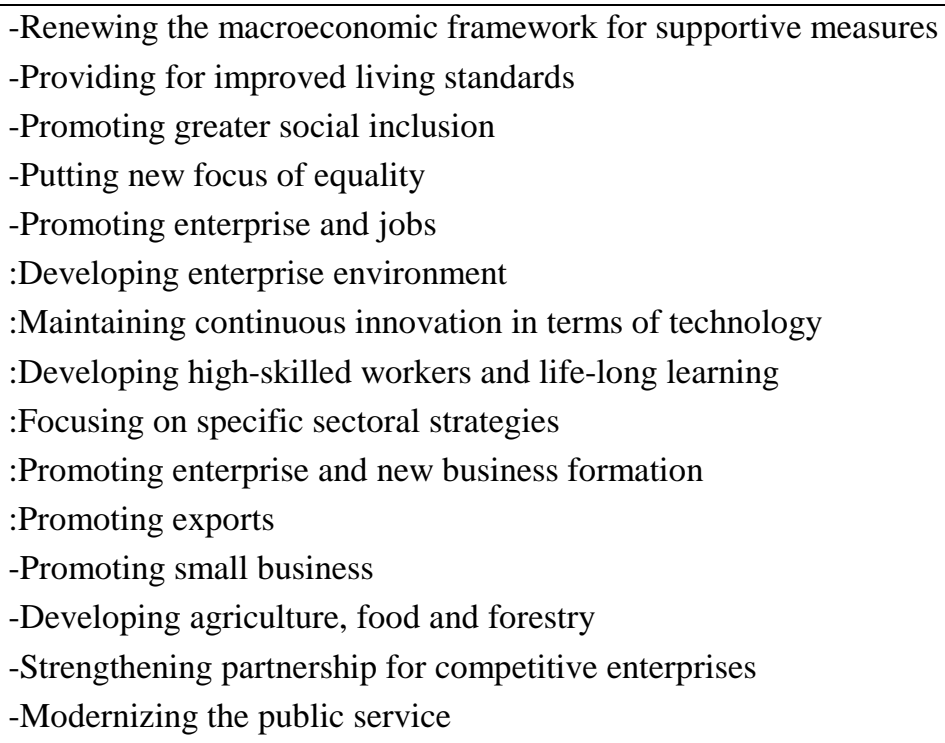

(Source: Partnership 2000, 1996)

Throughout the national development programmes, Irish Government embedded strategies promoting FDI, Industry, Enterprise and Knowledge development in national development strategies. In particular, it adopted strategic directions for FI promotion combining industrial development promotion with FDI promotion, and integrated these into knowledge-based enterprise development promotion (EK promotion) focusing on knowledge and innovation at the enterprise level. All these were ultimately integrated into the FIEK-brand strategy.

\subsubsection{D-IBS: FIEK-I (1987-1990)}

The FIEK-brand strategy over the period of 1987 to 1990 (Table 62) focused on FI promotion strategy combining FDI promotion within an industry development strategy. It was particularly formulated to create a flagship project that would build the International Financial Services Centre (IFSC) in Dublin, along with attracting FDI in the international manufacturing and services sector. In 1987, the Government - with EU approval - set out Dublin's IFSC project in legislation. To provide the cornerstone for the project development, a place redevelopment strategy was formulated on the one hand and a marketing strategy was designed by IDA in cooperation with the government marketing group on the other. In line with devising a place redevelopment strategy for IFSC project, the Customs House Docks Development Authority (CHDDA) was established to develop a site plan and to oversee the redevelopment of the area. A marketing plan articulated that the key feature of the strategy was to concentrate IDA resources worldwide in those sectors and markets in which Ireland had the greatest competitive advantage (e.g. electronics, pharmaceuticals and healthcare, international services, and financial services) in comprehensive terms, and at the same time insisted that it was imperative to exploit them to maximise investment and job creation opportunities from new sources in areas of 
increasing opportunity (e.g. financial services). The IDA maintained the existing markets (e.g. USA, Europe) while putting increased emphasis on new markets (e.g. the Far East). With respect to the sources of competitive advantage, it focused on securing investment from key overseas companies in target markets.

Table 62 Strategic directions of FIEK Promotions (FIEK-I)

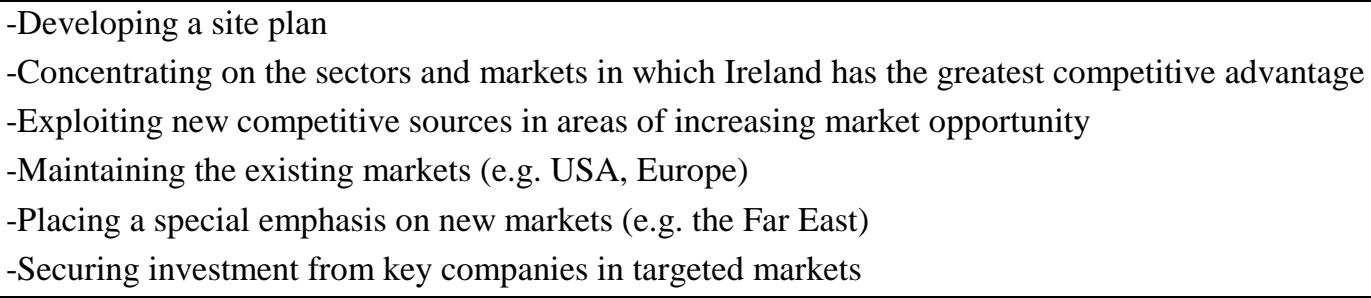

\subsubsection{D-IBS: FIEK-II (1991-1998)}

The FIEK-brand strategy in the 1990s focused on developing an enterprise promotion strategy that would integrate FDI promotion and IP into enterprise development. In general, the strategy was to maintain Ireland's attractiveness as a business location with the requirements of business (e.g. remote data centres, support-office services, education and information services). The combined approach, i.e. FI promotion, by the IFSC project was augmented by PESP and PCW, in terms of creating an attractive and efficient infrastructure through the development of the Customs House Docks Area, establishing a competitive and stable business environment, and promoting the development of new business. Through 'A Strategy for Enterprise in Ireland in the $21^{\text {st }}$ Century (1996)', Forfás articulated five main strands to the proposed strategy for the direct promotion of the enterprise sector: harnessing the growth potential of the services sector; transforming Irish-owned industry into innovative and competitive business; expanding the flow of inward investment in both the services and manufacturing sectors; promoting international trade and market development; and securing financial support for enterprise promotion. Among these strategic pillars, the FIEK-brand strategy was envisaged with a number of key elements at the direct promotional level and supportive measures as described in Table 63:

Table 63 Strategic directions of FIEK Promotions (FIEK-II)

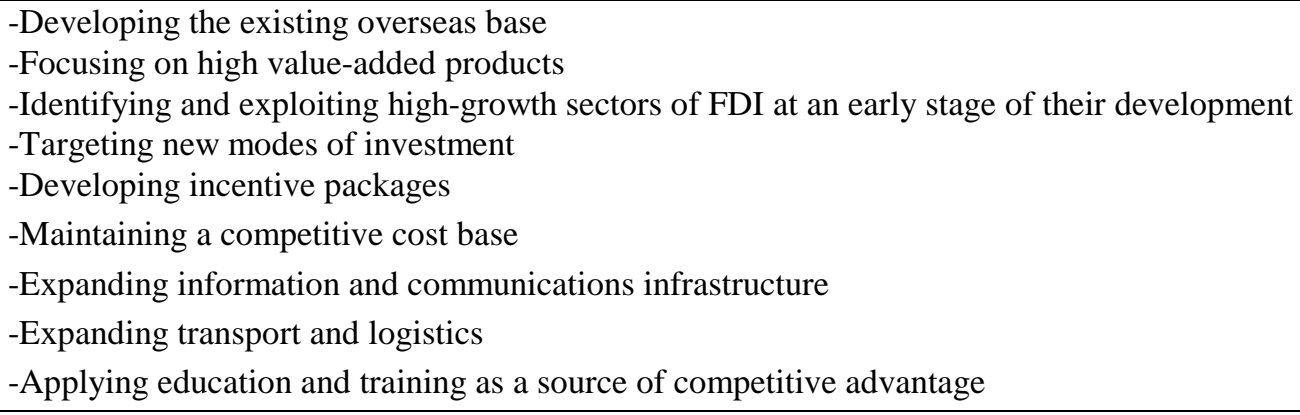




\subsubsection{D-IBS: FIEK-III (1999-2003)}

In 1999, the FIEK-brand strategy (Table 64) was a far more detailed strategy focusing on the promotion of knowledge and innovation in overall enterprise development. In the case of promoting foreign-owned industry, Forfás placed the greatest emphasis on: qualitative factors that deepened investment and activities by enterprises rather than simply quantitative aspects; developing and strengthening the existing base of FDI projects in Ireland as a source of sustainable output, export, sub-supply opportunities and employment; the employment and development needs of Irish regions. It was important to continue to offer an attractive overall "package" such as financial incentives to mobile investors. In line with promoting industrial development, it placed a strong emphasis on diversifying the sectoral spread in high technology between electronics, software and pharmaceuticals/health care for optimum market positioning. For target markets in FDI promotion, it was necessary to maintain the level of US FDI while identifying further opportunities in European and Asian countries.

Table 64 Strategic directions of FIEK Promotions (FIEK-III)

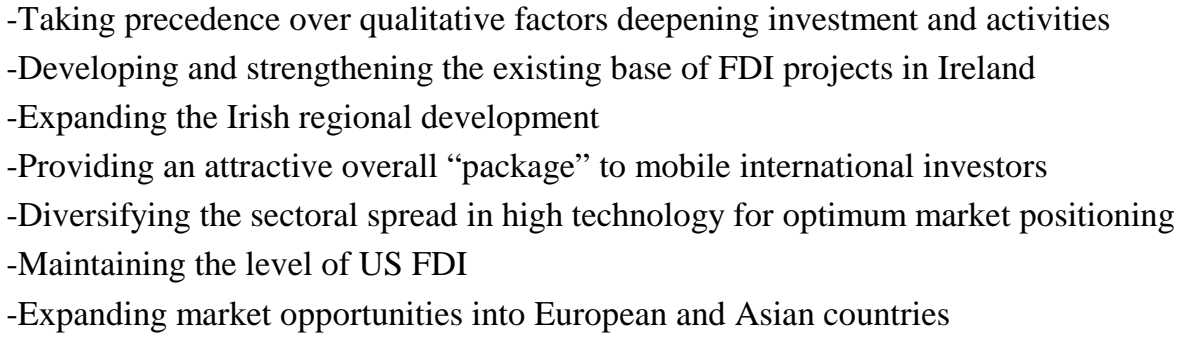

Along with the general FIEK-brand strategy, the IFSC-brand strategy over the period was developed to consolidate the 'IFSC and Docklands' brand images positioning Ireland as a world-class hub for an international financial centre. Moreover, the FIEK-brand strategy emphasized the leveraging of their brand images to maintain a vibrant and growing international financial services industry in Ireland and to improve its sustainability through strengthened links to related sectors (shared services, electronic commerce and software development). In 1999, the Government adopted a strategy (Table 65) for the development of the International Financial Services Industry in Ireland. Recognizing the importance of an effective, properly-enforced and up-to-date system of company law to international perceptions of Ireland as a business centre, the Government (i.e. Department of the Taoiseach) encouraged both industry and the public sector regulators and policy-makers to participate in Government-led initiatives that would identify and remove potential obstacles to the development of the electronic delivery of financial services and to adopt a proactive approach to ensuring that Ireland would be well placed within Europe as a location for such businesses. 
Table 65 Strategic directions of IFSC Promotion (FIEK-III)

-Publicly reaffirming the Government's commitment to the development of the international financial services industry in Ireland

-Organizing a Seminar in June 1999 by IDA Ireland with the assistance of the Department of the

Taoiseach, other Government Departments and Agencies, and industry

-Nominating IFSC liaison officers/specific IFSC sections as a Public Sector Group chaired by the

Department of the Taoiseach to ensure the operation of the Strategy and the follow-up

-Comfirming the Docklands as the hub for the long-term development of the industry in Ireland

-Encouraging front-office financial services companies to locate within the Docklands hub, close to the IFSC

-Developing promotional materials for marketing the attractions and opportunities of the Docklands hub for financial services businesses and marketing Ireland as a financial services location by the DDDA in association with the marketing arrangements of IDA Ireland

-Developing and implementing a revised marketing plan for the promotion of the industry

-Considering the suggestion for an 'IFSC brand'

-Inviting people involved in education initiatives, the Department of Education and Science and FÁS at IFSC Working Group meetings

-Continuing to promote educational initiatives in the Docklands Area

-Reviewing the progress on educational and training needs and provision at the Clearing House Group in November 1999

-Continuing effective consultation with the international financial services industry on tax issues

-Broadening Ireland's network of tax treaties

-Implementing proposals from the IFSC Funds Group already agreed in the forthcoming Companies

(Amendment) Bill

-Taking a more proactive approach towards the development of the industry

-Responding rapidly to proposals to improve the competitive position of the industry while maintaining the necessary prudential safeguards

-Continuing to provide a coherent input to considerations on the establishment of a Single Regulatory Authority from the perspective of the development of the international financial services industry

-Monitoring the effectiveness of a package of tax and company law measures

-Preparing a report on the impact of the euro for the international financial services industry in Ireland, outlining strategic opportunities and threats arising and appropriate responses

-Prioritizing the provision of high-bandwidth telecommunications links in the IFSC

-The Clearing House Group will review and oversee the follow-up to the proposals outlined in the report on pensions commissioned by the FSIA

-The Department of Finance, in consultation with industry, will seek to produce legislation for Finance Bill, to facilitate the growth of securitisation, within the context of EU and domestic policy concerns -Proposals emerging from the Report commissioned on an IMBC will receive positive consideration from the Minister for the Marine and Natural Resources and the Government with a view to their early implementation

(Source: Department of the Taoiseach, 1999) 


\subsection{OPERATING AN IRELAND-BRAND STRATEGY (O-IBS)}

\subsubsection{O-IBS: FIEK-I (1987-1990)}

FIEK-brand promotions over the period of 1987 through 1990, i.e. FIEK-P (I), (Table 66) were vigorously pursued by creating and developing the International Financial Services Center (IFSC) in the Custom House Docks Area of Dublin's City Centre. The Urban Renewal Act of 1987 delineates the boundaries of the area, lying between Amien Street to the west, Common Street to the east, Sherriff Street Lower to the north and Custom House Quays to the south. The Customs House Docks Development Authority (CHDDA) was established and took responsibility for redevelopment planning and control of the IFSC area. Special incentives, such as a 10 per cent corporate tax regime, were available for companies invoved in the IFSC.

The IDA took responsibility for the detailed promotion of the IFSC to the worldwide financial services sector and established a special unit to undertake comprehensive marketing and to follow up the projects that gave rise to job-creating investments. In conjunction with the IFSC project, IDA put marketing efforts not only into attracting mobile international investment from the US, Europe and the Far East but also focusing on all the major financial institutions in the US, UK and Japan. The United States was targeted as the prime source of greenfield investment commitments and for the investment expansions in Ireland. For the US market, it emphasized Ireland's strengths in skills, as a member of the EC and as a consistently profitable location for US investment. Along with European markets, greenfield projects and expansions were made. Marketing in Europe was segmented and tailored to each country based on its competitive advantage that fitted Ireland's needs. For the Japanese market, the IDA identified and selected target companies in key investment sectors such as electronics, international service projects, particularly in the computer software and data processing sectors, pharmaceuticals, and automotive components. Those international companies were widely dispersed throughout the Irish regions. In particular, IDA's marketing in Japan focused on component and parts manufacturers which had a strategic need to supply Japanese final assembly plants in the EC. The Prime Minister and the Minister for Industry and Commerce visited Japan in 1989 and strengthened the on-going relations between the Japanese Ministry for Industry, Trade and Investment (MITI) and Ireland's Department of Industry and Commerce. A significant media campaign was launched in Japan in 1990 to create a more positive image of Ireland among Japanese businesses.

Along with the development of IFSC, the Government took several initiatives. In particular, the Prime Minister himself became involved in the initial marketing effort and gave presentations at the meeting which he hosted on Wall Street, convincing investors of Irish competency and availability for their business operation in Ireland. The Prime Minister had a great respect for competent civil servants and enthusiastically took the ideas 
suggested by them. The Prime Minister and government selected "Three Wise Men" from the Revenue Commissioner and the Department of Finance and organized the Governments Representative Group. The IDA and those three members traveled the world for the first few years and communicated with the very top people in the international financial services industry.

Table 66 FIEK Promotions over 1987-1990: FIEK-P (I)

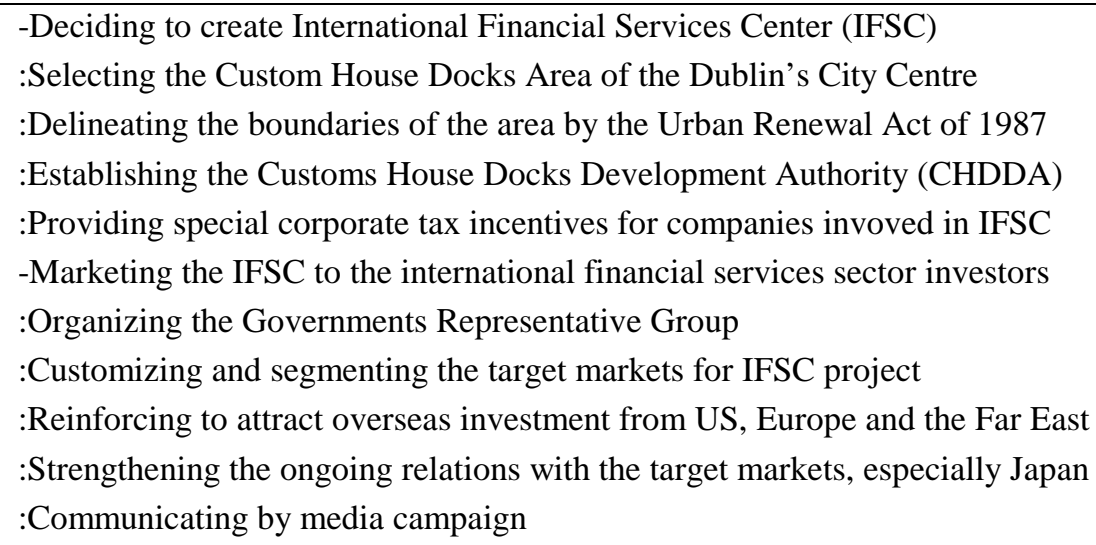

\subsubsection{O-IBS: FIEK-II (1991-1998)}

FIEK-brand promotions in 1990s, i.e. FIEK-P (II), (Table 67) were primarily reinforced by maintaining the taxation benefit that was essential to establish a competitive and stable business environment. The key incentive, i.e. the $10 \%$ corporate rate for manufacturing, for mobile international investment was extended from 2000 to 2010. Moreover, the Government announced that a similar extension of the $10 \%$ tax status would be applied for IFSC companies to 2005. Since the first development of the IFSC (IFSC-I) was completed in 1992, the Custom House Docks Area had been extended with budget allocation. The CHDDA preliminarily undertook a number of feasibility studies prior to the preparation of the plan: a land use and condition survey; a survey of existing and planned services and utilities; a re-examination of all site investigation data; a study on the likely future demand for IFSC space; a forecast of the demand for retail space; transportation and movement, with particular reference to parking demand; urban design studies, with particular reference to building heights. In its 90th meeting, the CHDDA on February 1994 decided to amend the Planning Scheme (1987) to include both the Sheriff Street flats site and the National Sports Centre site as well as areas not previously covered in the Planning Scheme, i.e. the area in front of the existing Custom House Docks site extended to the centre of the River Liffey, Connolly Station and the An Post sorting office on Sheriff Street. Under the Dublin Docklands Development Authority Act 1997, the Dublin Docklands Development Authority (DDDA) assumed the functions of CHDDA for the period of development of IFSC II. While the development during IFSC-I and Planning Scheme 1994 focused on a high-class business enclave and the physical regeneration of the 
area, the DDDA adopted a holistic approach to strengthening cultural attractions and social integration on a sustainable basis. On the basis of the principle of sustainable development, in 1997 the DDDA adopted the Master Plan that addressed the general challenge in terms of providing a real choice for those who wish to live in the area, translating the aspirations of the communities within the area into the gain to be shared by those living and working in the area, providing a renewal strategy for rehabilitating under-utilized areas, promoting world class architecture and urban design, and promoting the principles of sustainability in architectural/urban design.

Along with developing an attractive and efficient infrastructure, the IFSC Committee was restructured in order to facilitate an increased input from the financial industry in policy formulation. Working groups were formed for broadening the range of services and for supporting the development of new products in areas such as insurance, funds, banking and corporate treasury. International marketing of the Centre was added since IDA Ireland (Industrial Development Agency Ireland) was in 1994 established as an agency of Forfás under the provisions of the Industrial Development Act, 1993.

With the misson "We will win for Ireland, its people and its regions, the best in international innovation and investment so as to contribute to the continued transformation of Ireland to a world-leading society which is rich in creativity, learning and personal and social-wellbeing...", IDA Ireland proactively networked and collaborated with Government departments, the Higher Education Authority, FÁS, Vocational Education Committees, Regional Technical Colleges and Universities to ensure a good match between supply and demand for specific skills of companies from overseas. IDA Ireland undertook intensive promotion with the existing base of overseas companies to stimulate the growth of back office centres in Ireland, where companies could undertake their data-processing, accounting, software, customer support and teleservices operations for the whole of Europe from a single location. As the volume of potential greenfield investment was declining, IDA Ireland critically focused on encouraging more R\&D activity to the enterprises already in Ireland. For market positioning with competitive products, the Agency selected not only from the computer manufacturers but also a wide range of segments within information and communication technology industries (ICTs), which spanned hardware and software, computers, telecommunications, components, peripherals, internet, networking systems, and data processing. The US market had always been considered as the most important market for Ireland, in particular, in the targeted sectors with electronic, healthcare and pharmaceuticals with software, some financial services, teleservices and shared service facilities being the dominant non-manufacturing sectors. Increasingly, FDI promotion to the US market was focused on attracting enterprises based on knowledge intensive and high-value added products. This approach was also applied to European countries and Japan primarily in the services as well as in a small number of niche, knowledge-based, manufacturing sub-sectors where Ireland continued to enjoy competitive advantage. To ensure better distribution of both overseas investment and industrial development in the 
Irish regions, the Regional Development Division within IDA Ireland was established and provided a local service to industry and communities in the Irish regions. It also offered a particularly attractive financial incentive package in favour of regional locations, along with attractive property solutions.

The Government initiated the development of the communication message. To promote science, technology and innovation (STI) at all levels of society, the 'Science, Technology and Innovation Awareness Programme' was consolidated with young people and their educators, key decision makers in business and government and the general public. The programme highlighted the benefits to Ireland that can accrue from STI, introduced people of all ages to exciting developments in science, technology and engineering and encouraged learning through enthusiastic participation in STI-based activity at home, at work and in school. To deliver the response to the challenges of EMU (European Monetary Unit) membership, the 'EMU Business Awareness Campaign' was created by Forfás, which launched a range of comprehensive and user-friendly information material such as the Campaign's Information Pack which was disseminated through a newsletter, Forbairt magazine, meetings and seminars, on the Campaign's website and, later, through radio and newspaper advertising, as well as direct mail to small businesses, being conducted with the cooperation of the Revenue Commissioners. A national conference, entitled 'The euro and Business: Preparing for Action', was held in Dublin Castle on April 1997. Over two hundred people from business and the public service participated in the conference. They shared the business planning tools prepared during the Campaign to help enterprises in their preparations for the changeover and discussed the implications of policy changes by the banking sector and the Revenue Commissioners.

Moreover, for FIEK promotion, the National Competitiveness Council was established to identify the main competitive challenges facing the enterprise sector over the medium term and the required policy responses. The Irish Council for Science Technology and Innovation (ICSTI) was founded to advise the Government on the strategic direction of science and technology policy. To develop STI infrastructure, the Government established the $£ 250$ million Scientific and Technological Education (Investment) Fund. Encouraging an Education-Business Partnership, the Government announced the establishment of the Expert Group on Future Skills. Forfás provided the research support and Secretariat to these councils. Moreover, Forfás coordinated awareness campaigns on the EMU, on Science, Technology and Innovation and on Skills. 
Table 67 FIEK Promotions over 1990s: FIEK-P (II)

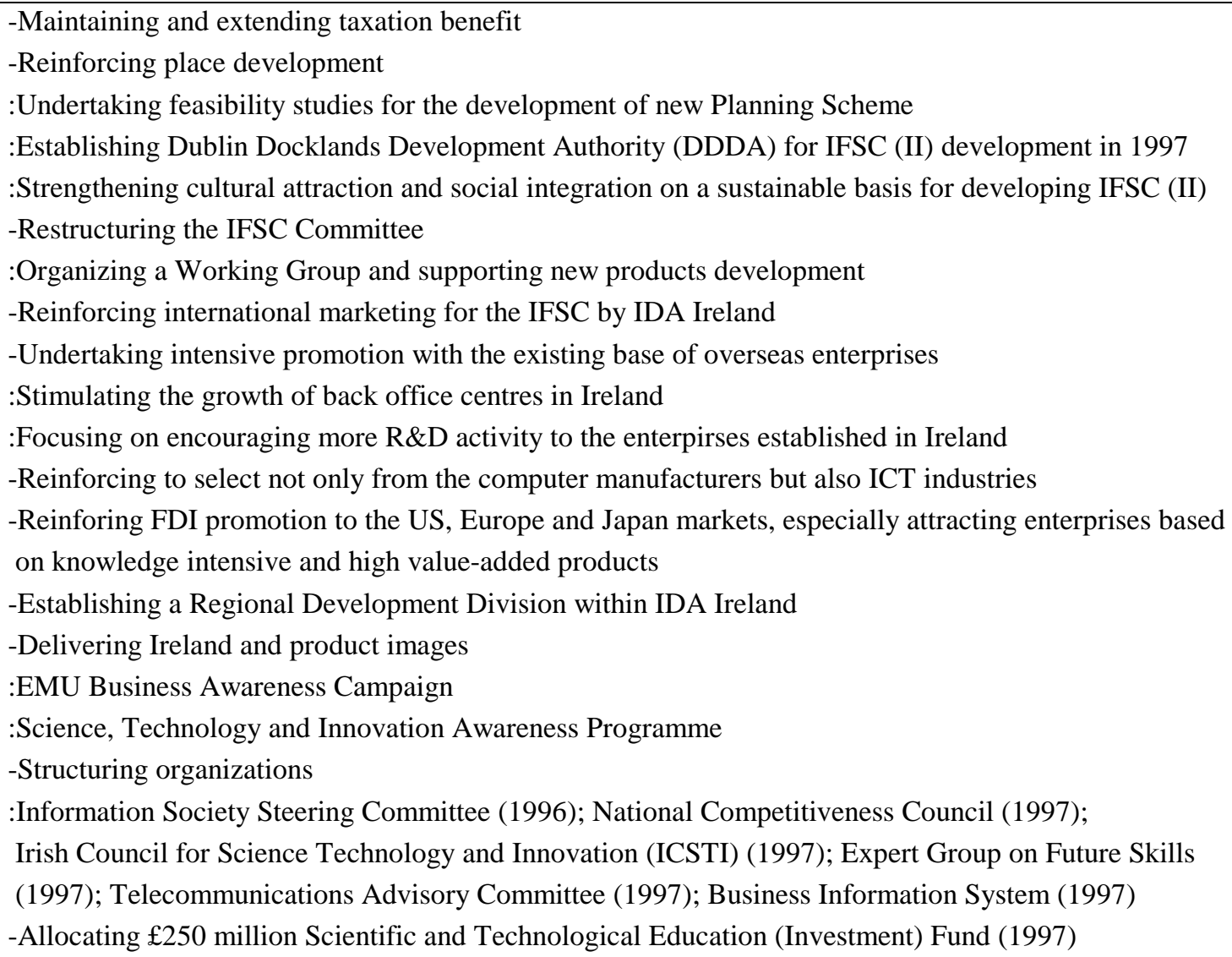

\subsubsection{O-IBS: FIEK-III (1999-2003)}

FIEK-brand promotions since 1999, i.e. FIEK-P (III), (Table 68) have been strengthened by the activities that FIEK-brand promotions during phase I and II were developing, and were extended for new initiatives in 2000s. The IFSC Clearing House Group under the aegis of the Department of the Taoiseach directed the consultative process supporting the Government's IFSC-brand Strategy. A new vision for IFSC in 2000s was published after a seminar. A Group of public sector representatives was established to provide continuity in policy-making for the international financial services sector. The DDDA worked to implement its Development Strategy for accommodation and infrastructure for international financial services in the Docklands area and enhanced the area with cultural and leisure amenities. The Department of the Taoiseach and the Financial Services Industry Association ('the FSIA') jointly commissioned a feasibility study into the establishment of a dedicated training facility with links to IFSC companies. Industry associations took the lead role in the training area. Industry representatives and education providers promoted the IFSC as a career option. The DDDA initiated a school-job placement programme. This programme also provided new employees with evening classes in foundation skills in financial services developed by the DDDA and employers. For the National College of Ireland to move into its proposed Docklands Campus, the Government 
allocated $£ 7 \mathrm{~m}$. The DDDA allocated a site for its new premises in the 12-acre extension of the IFSC. A number of measures were implemented in line with the Government Action Plan on Implementing the Information Society in Ireland. The $12.5 \%$ corporation tax regime was set up. The Revenue Commissioners have continued to work to expand Ireland's tax treaty network worldwide.

IDA Ireland developed marketing plans in consultation with the IFSC Working Groups and implemented marketing plans for the IFSC sectors. Sectoral specialists were nominated within the IDA to market the banking and treasury, funds, life insurance and non-life insurance sectors. The IDA identified a new performance measurement system to replace IFSC certifications and job number commitments. The approval process for companies locating in the IFSC involved various state agencies. Licensing and tax approval involved IDA Ireland and certification involved the Irish Central Bank and Department of Finance. The lead role in the development of policy and co-ordinating future development involved specialized working groups together with industry. Policy measures were taken by the Department of the Taoiseach (Prime Minister). The importance of e-commerce was also recognised in the IDA marketing plans.

To create knowledge-based industries and achieve improved levels of productivity and innovation, the Government in 2000 established a Technology Foresight Fund. This was intended to make Ireland an internationally recognised centre of research excellence, particularly in areas of Information and Communications Technology (ICT) and Biotechnology. To administer the Fund, Science Foundation Ireland as the National Foundation for Excellence in Scientific Research was subsequently established under the Forfás legislation. To implement government policies and programmes, the IDA focused on regional development promotion, balancing the competing requirements of international business and the needs of regional locations, and took account of the strengths and resources of each region. To ensure that Irish branches of global companies continued to add substantially to the value chain within their corporate entities and respond to the changing competitiveness features of the Irish economy, IDA created development programmes encouraging enterpises to systematically move up through the value chain, embedding themselves more firmly in the Irish economy. The IDA became actively involved in promoting and supporting many of the developments of e-Business initiatives (e.g. 'Global Crossing') and started a major promotional drive to bring leading international companies into Ireland to establish their e-Business services for Europe.

The IDA put effort into identifying and building niches in which Ireland could be a leader. Convinced that the single most important contributor to build strong clusters would be the level of world-class innovation arising out of the strengthening links between business and third level education and other research centres in the country, the IDA collaborated with Science Foundation Ireland ${ }^{17}$ and Enterprise Ireland. These agencies built

${ }^{17}$ It is established as the National Foundation for Excellence in Scientific Research under the Forfás legislation in 2000 
strong partnerships and collaboration between industry and universities, undertaking together substantial $\mathrm{R} \& \mathrm{D}$, be it in product, process, technology or the management of innovation, and work to a common strategy in the fields (e.g. digital media sector, communications management software) to facilitate seeking out new niches of business in which Ireland could be a leader. Coordination of the industrial development agencies was a core function of Forfás, which was achieved by operational consistency through a number of mechanisms, including the Board of Forfás and the Inter-Agency Planning Managers' Group.

Awareness campaigns were continued to distribute key messages to the enterprise sector using the medium of advertising. In addition, they were extended into a national campaign using both print and national radio. The campaigns also were continued with a wide range of other information initiatives, including stands at exhibitions and conferences, presentations at meetings and seminars, as well as handling a large number of queries on the campaign's helpline for business. The National Skills Awareness Campaign was coordinated by a Management Committee composed of representatives of IDA Ireland, Enterprise Ireland, FÁS (Ireland's National Training and Employment Authority)'s education division and private industry. The National Innovation Conference, organised by Forfás, was held to investigate how to leverage creativity for competitive advantage at all points in the business value chain and to make policy recommendations that would, if implemented, help add value in all sectors of society.

Table 68 FIEK Promotions since 1999: FIEK-P (III)

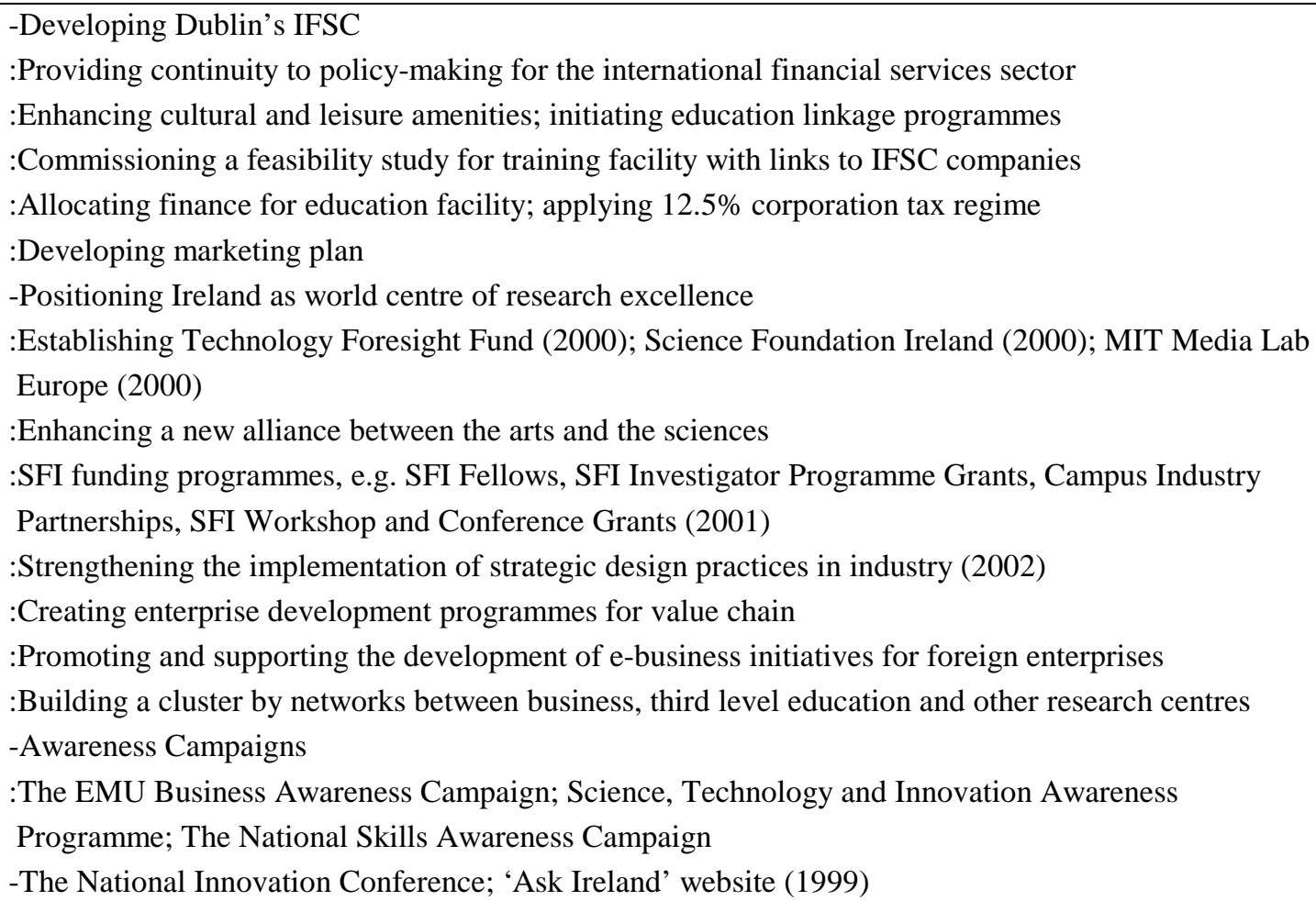




\subsection{SUSTENANCE OF COMPETITIVENESS OF IRELAND}

\subsubsection{National Development Goal \\ Economic and Social Development}

From 1986 Ireland had a shared national vision of rebuilding Ireland as a cohesive society with sustainable employment and competitiveness by 1990, accomplishing a selfsustained development through enterprise innovation in the 1990s, and sustaining the virtuous circle of the achievements in economic and social inclusion in the 2000s. In line with national visions, the Government and its social partners have envisaged Irish economic and social development goals. Referring to Ireland's economic performance (Table 69), GDP growth over the period of 1987 to 1990 reached nearly 5 per cent and in 2000-2003 maintained a similar level. Over the period of 1994 to 2000, in particular, Ireland accomplished substantial growth not only in economic performance but also in social development related to overall employment and unemployment. GNP and GDP both grew by 8 to 9 per cent. According to the OECD, Ireland's employment expansion in 199499 highlighted the extremely favourable context for reducing unemployment, poverty and social exclusion. The Government's target of a 7.0 per cent unemployment rate by end-year 2000 was achieved within a year of its adoption (NESC, 1999; Department of Enterprise, Trade and Employment, 1998).

Table 69 Ireland economic and social development: 1987-2003

\begin{tabular}{|c|c|c|c|c|c|}
\hline & $1981-86$ & $1987-90$ & $1991-93$ & $1994-2000$ & $2000-2003$ \\
\hline $\begin{array}{c}\text { GNP } \\
(\text { Average annual \%) }\end{array}$ & 0.1 & 4.9 & 2.2 & 9.0 & 6.3 \\
\hline $\begin{array}{c}\text { GDP } \\
(\text { Average annual \%) }\end{array}$ & 2.1 & 5.5 & 2.8 & 8.4 & 5.4 \\
\hline $\begin{array}{c}\text { Employment } \\
\text { Average annual \%) }\end{array}$ & -1.3 & 1.5 & 0.6 & 5.1 & 2.9 \\
\hline $\begin{array}{c}\text { Unemployment } \\
\text { Average annual \%) }\end{array}$ & 13.8 & 15.9 & 15.5 & 9.5 & 4.3 \\
\hline
\end{tabular}

(Source: NDP2000-2006; Central Statistical Office, 2006; Burnham, 2003; OECD, 2001; NESC, 1999)

\section{Human Development Value}

In 1986, Ireland established a shared national vision of rebuilding Ireland as a cohesive society with sustainable employment growth and competitiveness. Based on that shared vision, Ireland's branding was pursued to position Ireland to enter a virtuous circle for economic and social inclusion within Ireland. With its strong belief accomplishing social development and cohesiveness along with economic competitiveness, Ireland was nominated as the place with the best 'quality of life' (Economist Intelligence Unit, 2004). According to the Human Development Index (2005), Ireland has been increasingly sustaining a high Human Development Value (Fig. 25). Ireland has been progressive in 
achieving long and healthy lives, knowledge, and a decent standard of living for its people. Compared to the values of USA, Ireland in 1970s and 1980s remained at a relatively low level. However, since the 1990s Ireland has grown and in 2003 reached the level of wellbeing of USA.

Fig. 25 Human development value: Ireland (1975-2003)

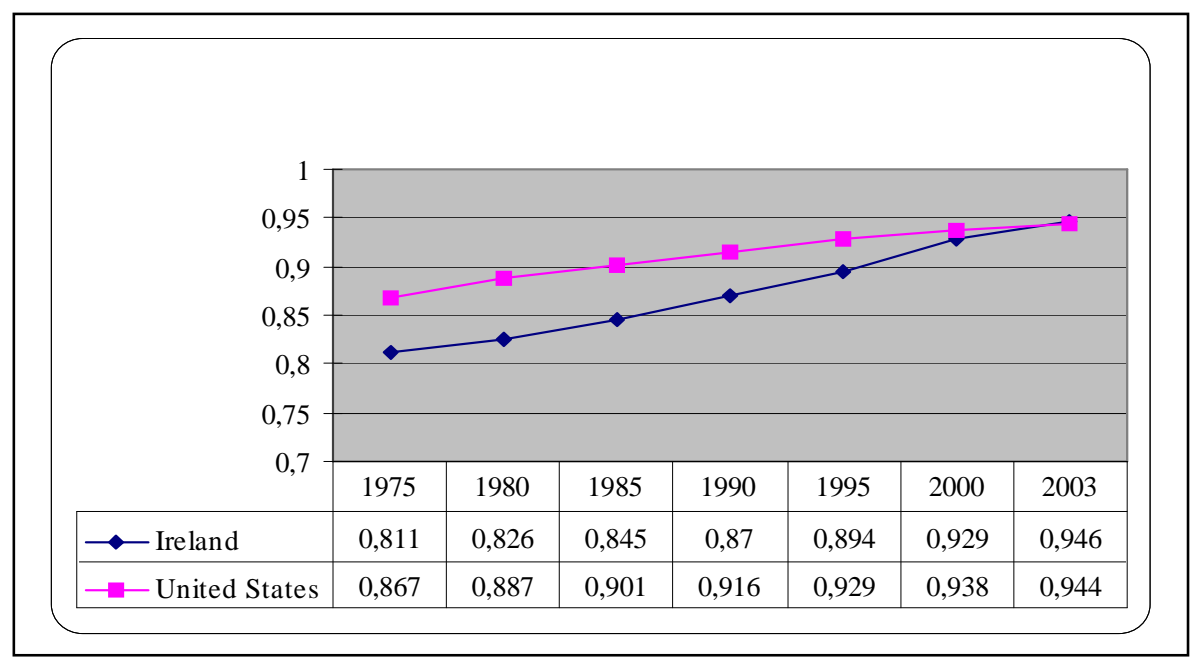

(Source: Human Development Report, HDI 2005)

\subsubsection{Project-based Goal Achievement FDI Competitiveness}

From 1987, Ireland put the emphasis on the brand goal of creating and developing the IFSC in Dublin's Docks Area, and the results provided Ireland with abundant economic competitiveness over the short-term period of FIEK-I. Through the second phase of FIEKbranding, the IFSC-brand project was developed and refined by accounting for brand attraction. From 1999, the IFSC became highlighted as the brand differentiator representing Ireland, which was demonstrated through the employment levels in the IFSC. As Ireland's economic hub, the IFSC in 2003 became a focal point encompassing 450 international financial institutions with around 16,000 employees, especially working in the funds and asset industries (42\%), banking (37\%) and insurance (21\%). According to figures from the European funds industry association (FEFSI) (Table 70), about the top ten leading funds centres in Europe, Ireland's growth rate amounts to 19 per cent of the total net asset value of authorized funds business, which surpassed the European average of 12 per cent. 
Table 70 Net assets of European investment funds industry (Dec. 2003)

\begin{tabular}{|c|c|c|c|}
\hline & Net asset value $(€$ bn) & Market Share $(\%)$ & Year on year \% change \\
\hline France & $1,008.0$ & 21.2 & +13.1 \\
\hline Luxembourg & 953.3 & 20.1 & +12.9 \\
\hline Germany & 822.0 & 17.3 & +9.5 \\
\hline UK & 418.8 & 8.8 & +13.1 \\
\hline Italy & 393.4 & 8.3 & +5.7 \\
\hline Ireland & 361.7 & 7.6 & +19.0 \\
\hline Spain & 204.9 & 4.3 & +18.6 \\
\hline Netherlands & 93.2 & 2.0 & - \\
\hline Austria & 92.1 & 1.9 & +7.3 \\
\hline Belgium & 83.5 & 1.8 & +8.2 \\
\hline
\end{tabular}

(Source: FEFSI, 2003)

Ireland has attracted inward investment in pursuit of enterprise development. Enterprise sectors encompassing indigenous and overseas firms were highlighted as the primary source driving Ireland's competitiveness, which was connected to reinforcing enterprise development promotion integrating FDI promotion into industry development promotion. In terms of enterprise competitiveness that represents competitive advantage by the enterprise sector, according to a Forfás report, some 298,000 Irish jobs by 2003 were in companies supported by the enterprise development agencies, increasing from 217,500 in 1993. In particular, foreign-owned enterprises recruited more than 50 per cent full-time jobs and employed more than 100 people within a firm. In sales and export volume, foreign-owned enterprises accounted for a high proportion of the total volume. Over the same period, employment in the entire economy increased from 1.2 million to approximately 1.8 million.

Table 71 Agency-supported firms in manufacturing and internationally-traded services

\begin{tabular}{|l|l|l|l|}
\hline & Total & Indigenous & Foreign-owned \\
\hline Number of firms & 8,663 & 7,390 & 1,273 \\
\hline Number of full-time employees & 297,549 & 147,895 & 149,654 \\
\hline Average number of employees per firm & 34 & 20 & 118 \\
\hline Sales (€m) (2002) & 99,341 & 23,588 & 75,753 \\
\hline Exports (€m) (2002) & 78,803 & 8,785 & 70,018 \\
\hline
\end{tabular}

(Source: Forfás, 2004; Forfás Surveys, 2003)

Given the increase in competitiveness resulting from attracting inward direct investment (i.e. FDI development level), Ireland continued to have a high stock of inward FDI relative to GDP (Fig. 26). The stock of inward Foreign Direct Investment (FDI) in Ireland by 2004 was equivalent to 126 per cent of the GDP (or approximately 158 per cent of GNP) - higher than any other country benchmarked and at considerable distance ahead of second-placed Netherlands (75 percent of the GDP). The IFSC FDI stock comprised 
around 40 per cent of the total FDI stock (Barry, 2005; CSO, 2003). According to the degree of transnationality of host countries, which reflects both the total activity of transnational corporations (TNCs) and the expansion of FDI stock in the host country, in 2003 Ireland has achieved the highest position as the most transnationalized country among the developed countries (UNCTAD, 2006:11).

Fig. 26 Foreign Direct Investment Inward Stock (\% of GDP), 1990-2004

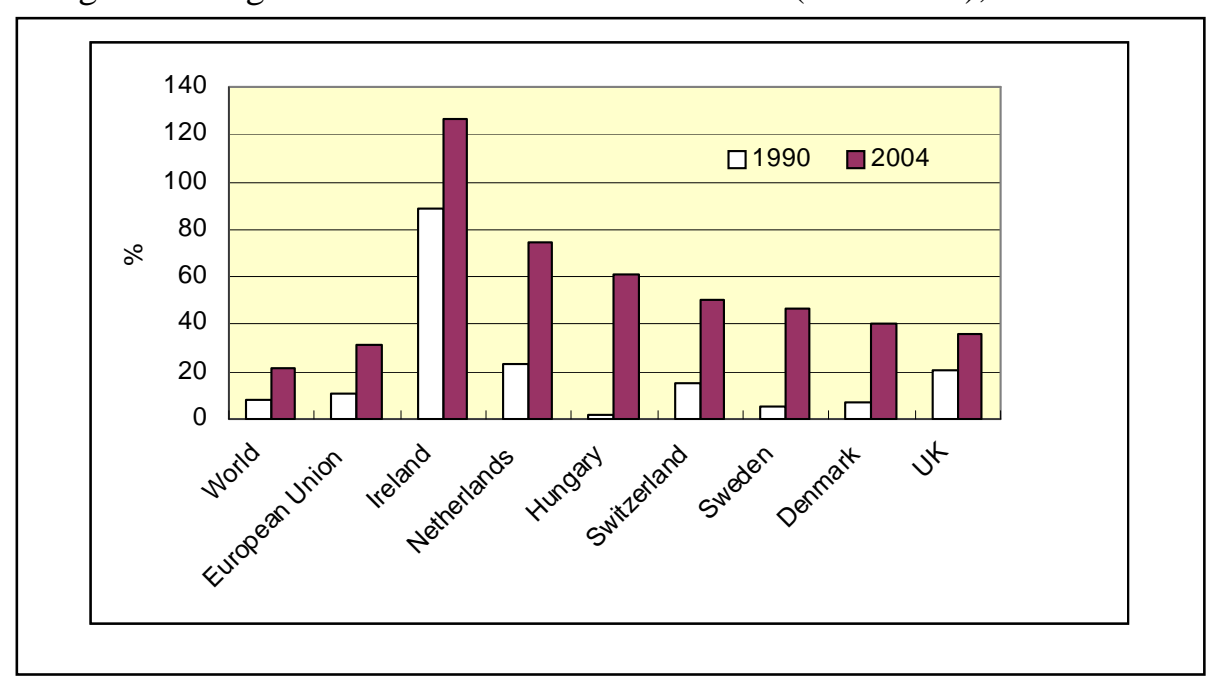

(Source: Forfás and National Competitivenss Council, 2006; UNCTAD, 2006)

\subsubsection{Nation Brand Equity \\ Product Attribute-based Equity}

Enterprise competitiveness on the basis of industrial products from Ireland evolved along with FDI market. Electronics and pharmaceuticals/ healthcare were the main sectors in the 1970s. In the early 1990s, financial services, software and specialized components started to change Irish industry. By the end of the 1990s along with brand vision, knowledge-based products from Information and Communication Technologies (ICT) sector were highlighted as the main source of competitive identities. In particular, the three industries of chemicals, office machinery and computer services were heavily dominated by foreign-owned enterprises (ACR, 2004:87). Turning to employment performance based on industry sector, total employment growth confirmed the strong growth in Irish competitiveness (Table 72). 
Table 72 Total employment by sectors

\begin{tabular}{|c|c|c|c|c|c|c|c|}
\hline Sector & 1972 & 1992 & 1999 & 2000 & 2001 & 2002 & 2003 \\
\hline ICT & - & - & 45,651 & 52,624 & 46,513 & 43,660 & 41,459 \\
\hline $\begin{array}{c}\text { Pharmaceuticals, } \\
\text { healthcare, } \\
\text { Chemicals }\end{array}$ & 5,592 & 12,083 & 17,045 & 17,856 & 18,587 & 18,996 & 19,463 \\
\hline $\begin{array}{l}\text { Electronics and } \\
\text { Engineering }\end{array}$ & 19,645 & 39,951 & 17,556 & 18,118 & 17,699 & 16,622 & 15,435 \\
\hline Miscellaneous & - & - & 12,153 & 11,739 & 10,633 & 9,964 & 9,242 \\
\hline $\begin{array}{l}\text { International and } \\
\text { Financial Services }\end{array}$ & - & - & 33,794 & 40,788 & 42,845 & 42,762 & 43,394 \\
\hline Total & - & - & 126,199 & 141,125 & 136,277 & 132,004 & 128,993 \\
\hline
\end{tabular}

(Source: IDA Annual Reports, 1992-2003)

Ireland has made great efforts to attract FDI enterprises, in particular targeting the US, Europe and the Far East. The US market has been the primary source for continuing new greenfield investment projects and expanding knowledge-based industries. European markets also have been targetted with a customized marketing strategy in line with Irish interests and needs. While the US and Europe markets have traditionally always been well served, the Irish Government has more recently paid special attention to the Far East market, especially Japan. In 1992, overseas enterprises included 371 from the US, which in 2003 increased to 489 companies with about 90,000 employees (Table 73).

Table 73 Origins of IDA supported companies

\begin{tabular}{|c|c|c|c|}
\hline \multirow[t]{2}{*}{ Origin } & \multicolumn{2}{|c|}{ No. of companies } & Total employment \\
\hline & 1986 & 2003 & 2003 \\
\hline US & 77 & 489 & 89,158 \\
\hline Germany & $31^{\mathrm{a}}$ & 149 & 11,394 \\
\hline UK & 33 & 118 & 8,086 \\
\hline Rest of Europe & 29 & 214 & 15,602 \\
\hline Asia Pacific (Far East) & 3 & 44 & 2,937 \\
\hline Rest of the World & 7 & 40 & 1,816 \\
\hline Total & 180 & 1,054 & 128,993 \\
\hline
\end{tabular}

(Source: IDA Annual reports, 1986; 2003)

\section{Ireland Brand Perception}

Ireland has positioned itself as a competitive location for FDI. In particular, Ireland's innovative and knowledge-based image stands out in international research. Demos, the independent UK-based think tank, has referred to Ireland as the most creative nation with significant growth in its creative occupations and its underlying creative capabilities since 1995. IMD reported that one of the reasons why so many companies choose Ireland was because of its unique workforce - Ireland had one of the youngest populations in Europe 
with over $36 \%$ under the age of 25 years. Moreover, Irish people's flexibility and agility (i.e. the Irish Mind) were reflected in the workforce, according to the report, which was recognized as the most unique Irish competency associated with Ireland brand.

Table 74 Flexibility and adaptability of the Irish People

\begin{tabular}{|c|c|}
\hline Ireland & 8.3 \\
\hline USA & 7.43 \\
\hline Portugal & 6.92 \\
\hline Netherlands & 6.86 \\
\hline UK & 6.60 \\
\hline Spain & 6.21 \\
\hline Czech Republic & 6.20 \\
\hline Germany & 5.56 \\
\hline Japan & 5.53 \\
\hline Hungary & 4.87 \\
\hline France & 3.85 \\
\hline
\end{tabular}

(Source: Adapted from IMD World Competitiveness Yearbook 2003; 2007)

\subsection{CONCLUSIONS}

Ireland-branding mechanisms based on a nation-brand system, i.e. FIEK, have encompassed branding actors and activities that have been aligned with Ireland's national strategic direction, and have influenced Ireland's sustainable competitiveness.

Over the period of FIEK-I (1987-1990), the NESC analyzed the existence of a virtuous circle in Irish economic and social development on the one hand and the possibility of a 'life-cycle' effect within successive generations of foreign enterprises established in Ireland on the other. In 1986, the NESC established a national vision of rebuilding Ireland as a cohesive society with sustainable employment growth and competitiveness. Considering the shared national vision, the Prime Minister decided on the FIEK-brand vision to create the IFSC in Dublin. Analyzing an increased level of investment commitments of overseas companies from the US and the Far East market and considering the brand vision, the Government and its social partners set the FIEK-brand goal, aiming to achieve a certain number of jobs through FDI promotion in industry and in the IFSC. Confronted with a national fiscal crisis, PNR (1987-1990) amounted to a national development strategy, primarily focusing on stabilizing the national economic condition on the one hand and, based on sectoral approach, articulating the Ireland-brand strategy to create the IFSC in Dublin on the other. The FIEK-brand strategy, in terms of promoting FDI and industry development, has been operated along with government policies, in particular, restructuring the international financial services industry and the FDI market. Place development and marketing practices were mainly considered. To communicate the IFSC brand, the Prime Minister and the Government took the initiative in attracting 
potential investors worldwide and strengthening the on-going relations with the target markets. Ireland over the period accomplished substantial growth not only in economic performance but also in social development related to overall employment. The IFSCbrand has been developed, accounting for its brand attractiveness.

In the 1990s, the NESC analyzed the high rate of unemployment and the necessity of securing a high rate of economic growth as a spur to employment growth. On the basis of the preliminary analysis regarding the enterprise development of Ireland, the NESC articulated a national vision of building a self-sustaining development for competitiveness and employment growth in the medium to long-run, and envisaged a brand vision sustaining a long-run competitiveness through enterprise innovation. Particularly elucidating the inter-relations between/among trade, FDI trends, Irish competitiveness and competition for FDI promotion between European countries, and considering the brand vision, the Government and its social partners set the specific goal of attracting FDI for a certain number of jobs. In 1996, Forfás presented a brand goal of aiming to reduce the unemployment rate, to increase living standards and to raise the quality of life of all of those living in Ireland. Reflecting the national development programmes and brand goals, Forfás contemplated the FIEK-brand strategy for a dynamic and competitive enterprise. The IFSC-brand strategy was concretized by creating an attractive and efficient infrastructure, establishing a competitive and stable business environment and promoting the development of new business. In line with the brand strategy based on the IFSC-brand, Dublin's IFSC project was reinforced by providing taxation benefits for IFSC companies, strengthening cultural attractions and social integration for place development and reinforcing international marketing. In general, FIEK-brand promotion during this period was undertaken for intensive promotion with the existing base of overseas enterprises. The computer manufacturers and ICT industries were selected for their brand attraction. A special fund for science and technology development was allocated. To attract FDI enterprises based on knowledge intensive and high value-added products, brand communication was concentrated on the existing FDI target market. Forfás, in conjunction with the Government, deployed communication programmes. Over the 1990s, with a significant economic and social development, the IFSC-brand has been refined. Ireland became one of the countries to be competitive in attracting FDI.

Considering the preliminary analysis regarding both technological change worldwide and the necessity of transforming Ireland into a knowledge-based society, the NESC envisaged a new vision of Ireland sustaining the virtuous circle of achievements in economic and social inclusion in the 2000s, and agreed to the brand vision positioning Ireland as a World Centre of Research Excellence based on enterprise competitiveness and social partnerships. The IFSC has been analyzed as the primary driver to improve Ireland's competitiveness. In line with the national vision, the Department of the Taoiseach has invigorated the brand vision maximizing the IFSC-brand. Analyzing the global market environment and technological change, Forfás has emphasized that increased productivity 
would be the fundamental basis for sustainable competitiveness. In line with the objective of increasing productivity, Forfás has set the brand goal to establish an enterprise environment for foreign companies' value-added activities and to create additional higher value-added jobs in the internationally-traded sector (manufacturing and internationally traded services). Considering the brand vision and the long-term viability of the IFSCbrand, the Department of the Taoiseach formulated the brand goal of building the positive "image" of the IFSC and promoting Ireland as a financial services location. Presenting the enterprise promotion strategy in 'Enterprise 2010', Forfás emphasized the need to strengthen the existing base of FDI projects in Ireland as a source of sustainability. The IFSC-brand strategy over the period was developed to consolidate the 'IFSC and Docklands' brand images, positioning Ireland as a world-class hub for international financial services. In particular, it was strengthened by educational linkage programmes, funding allocations for an education facility, special tax benefits, and marketing practices. To create knowledge-based industries and achieve an improved level of productivity and innovation, IDA Ireland helped to strengthen the links between business and third level education and other research centres in the country, and collaborated with both Science Foundation Ireland and Enterprise Ireland. These agencies built strong partnerships and collaboration between industry and universities to facilitate seeking out new business niches in which Ireland can be a leader. Forfás coordinated these agencies. Brand communication was maintained by awareness programmes and national conferences. Throughout the periods of FIEK, the IFSC has been developed and refined by accounting for brand attraction. Encompassing the successful productivity output and inflow levels in foreign-owned enterprises, Ireland has built a reputation in its FDI competitiveness based on the Irish competency. Knowledge-based products from the Information and Communication Technologies (ICT) sector were highlighted as the main competitive identities for FDI markets. Along with positioning itself as the competitive location for investment in Europe, Ireland has been nominated as one of the places with the best 'quality of life', increasingly sustaining human development value. 


\section{CHAPTER 7 ANALYSING PERFORMANCE IN KOREA AND IRELAND BRANDING}

\subsection{PERFORMANCE IN NATION BRANDING}

This research focuses on developing a model that explains the relevance between nation branding and the sustainable competitiveness of nations. The study is based on the 'Nation-Branding Mechanism Model (NB-MM)' as a research model described in Chapter 3. The NB-MM highlights how a nation sustains its competitiveness by nation branding through a mechanism-based process approach. In particular, it provides the criteria for performance in nation branding (Table 75), explaining a sequence of brand behaviours (i.e. branding actors and activities) that contextually take place within a nation-branding system and that influence the sustainable competitiveness of nations (see respective phases in section 3.2).

Table 75 The criteria for performance in nation branding

\begin{tabular}{|c|c|c|c|c|}
\hline & \multicolumn{3}{|c|}{ Branding Activities } & Branding Actors \\
\hline \multirow{4}{*}{$\begin{array}{c}\text { Phase I } \\
\text { Creating a } \\
\text { Nation-Brand Vision } \\
(\mathrm{C}-\mathrm{NBV})\end{array}$} & \multicolumn{3}{|c|}{ Analysing national resources and environment } & \multirow{4}{*}{$\begin{array}{l}\text { - Nation leader } \\
\text { - Government } \\
\text { - Social system }\end{array}$} \\
\hline & \multicolumn{3}{|c|}{ Developing a national vision } & \\
\hline & \multicolumn{3}{|c|}{ Taking a top-down or bottom-up approach } & \\
\hline & \multicolumn{3}{|c|}{ Creating a nation-brand vision } & \\
\hline \multirow{3}{*}{$\begin{array}{c}\text { Phase II } \\
\text { Setting a } \\
\text { Nation-Brand Goal } \\
\text { (S-NBG) }\end{array}$} & \multicolumn{3}{|c|}{ Reflecting a nation-brand vision } & \multirow{3}{*}{$\begin{array}{l}\text { - Planning group } \\
\text { - Social system }\end{array}$} \\
\hline & \multicolumn{2}{|c|}{$\begin{array}{l}\text { Reflecting a nation-brand vision } \\
\text { Analyzing branding resources and environment }\end{array}$} & & \\
\hline & \multicolumn{3}{|c|}{ Setting a nation-brand goal } & \\
\hline \multirow{4}{*}{$\begin{array}{c}\text { Phase III } \\
\text { Developing a } \\
\text { Nation-Brand Strategy } \\
\text { (D-NBS) }\end{array}$} & \multicolumn{3}{|c|}{ Reflecting a nation-brand goal } & \\
\hline & \multicolumn{3}{|c|}{ Identifying national strategy or development strategy } & $\begin{array}{l}\text { - Nation leader } \\
\text { - Government }\end{array}$ \\
\hline & \multicolumn{3}{|c|}{ Crafting brand positioning } & - Social system \\
\hline & \multicolumn{3}{|c|}{ Developing a nation-brand strategy } & \\
\hline \multirow{2}{*}{$\begin{array}{c}\text { Phase IV } \\
\text { Operating a } \\
\text { Nation-Brand Strategy } \\
\text { (O-NBS) }\end{array}$} & \multicolumn{3}{|c|}{ Identifying and developing brand identities } & \multirow[b]{2}{*}{$\begin{array}{l}\text { - Nation leader } \\
\text { - Governments } \\
\text { - Stakeholders }\end{array}$} \\
\hline & \multicolumn{3}{|c|}{ Communicating brand identities to the segmented targets } & \\
\hline \multicolumn{5}{|c|}{ Outcomes } \\
\hline \multirow{5}{*}{$\begin{array}{c}\text { Sustenance of } \\
\text { Competitiveness } \\
\text { of a Nation }\end{array}$} & \multirow{2}{*}{$\begin{array}{l}\text { National Development } \\
\text { Goal }\end{array}$} & \multicolumn{2}{|c|}{ Economic \& social development } & \multirow{5}{*}{-} \\
\hline & & Human developmer & & \\
\hline & $\begin{array}{c}\text { Project-based } \\
\text { Goal Achievement }\end{array}$ & $\begin{array}{l}\text { Product line-based } \\
\text { Competitiveness }\end{array}$ & $\begin{array}{c}\text { Tourism, } \\
\text { Export, } \\
\text { FDI }\end{array}$ & \\
\hline & \multirow{2}{*}{ Nation Brand Equity } & \multicolumn{2}{|c|}{ Product attribute-based equity } & \\
\hline & & \multicolumn{2}{|c|}{ Nation brand perception } & \\
\hline
\end{tabular}


To explore the complexity and uncertainty of nation branding, a case study was executed to collect data for comparison. Two cases were selected: Korea and Ireland. For case study, a triangulation approach to collecting empirical evidences was applied. By collecting data from multiple sources, each case has been initially explored and examined in Chapter 5 and 6.

The 'Nation-Branding Mechanism Model' encompasses a systematic and dynamic process between contextual parts (i.e. branding actors and activities) that are involved in nation branding. As articulated in section 4.2, our research compared the nation-branding process with that of other nations in order to identify nation-specific branding mechanisms, to identify the relevant contextual patterns in nation-branding process, and to identify similarities and differences in generating a nation-branding process.

This research explains contexts of the phases in the 'Nation-Branding Mechanism Model.' We further analyse cross-case patterns between branding of Korea and Ireland.

\subsubsection{CREATING A NATION-BRAND VISION (C-NBV)}

To promise a nation's truths and deliver itself as attractive to national or international communities, a nation-brand vision (NBV) needs to be defined as all countries differ. NBV is closely linked to the national vision and is created through the strategic analysis of national resources and environment. Branding actors are involved. Through branding actors and their activities, a nation's brand vision provides a yardstick of where a nation would like to be in the future.

Korea's brand vision (KBV) and Ireland's brand vision (IBV) have been created with specific characterisitcs (Table 76). Korea and Ireland have each analysed national economic and social development conditions, particularly focusing on current national difficulties and resources for competitive advantage. At the same time, they have analysed international market forces and major trends, and expected to seize opportunities in the competitive markets exploiting their own national sources of advantage. Based upon these analyses, both countries have developed national visions, particularly focusing on sustainable economic and social developments for the Korean and Irish peoples. To achieve their national visions, Korea has created nation-brand visions building 'Industrialized Korea based on Export first Principle' during ESTI-I, 'Industrialized Korea based on Heavy and Chemical industries and Export first Principle' in ESTI-II, and 'Science and Technology-advanced Korea through Nordpolitik and Segyehwa' for ESTIIII. Ireland has envisaged nation-brand visions building 'Ireland as the world's leading international financial services hub' during FIEK-I, 'Ireland sustaining long-run competitiveness through enterprise innovation' in FIEK-II, and 'Ireland as the World Centre of Research Excellence with IFSC competence' for FIEK-III. 
Table 76 Creating a nation-brand vision: Korea-brand visions and Ireland-brand visions

\begin{tabular}{|c|c|c|c|c|c|c|}
\hline \multirow{2}{*}{$\begin{array}{l}\text { Branding } \\
\text { Activities }\end{array}$} & \multicolumn{3}{|c|}{ Korea } & \multicolumn{3}{|c|}{ Ireland } \\
\hline & ESTI-I & ESTI-II & ESTI-III & FIEK-I & FIEK-II & FIEK-III \\
\hline $\begin{array}{c}\text { Analysing } \\
\text { National } \\
\text { Resources \& } \\
\text { Environment }\end{array}$ & $\begin{array}{l}\text {-Economic } \\
\text { Dependence } \\
\text {-National } \\
\text { security } \\
\text {-Advantage } \\
\text { source of the } \\
\text { diligent and } \\
\text { motivated } \\
\text { people }\end{array}$ & $\begin{array}{l}\text {-National } \\
\text { defence } \\
\text {-International } \\
\text { market boom } \\
\text { by HCIs }\end{array}$ & $\begin{array}{l}\text {-Market- } \\
\text { based } \\
\text { economy } \\
\text {-Needs } \\
\text { balancing } \\
\text { social and } \\
\text { economic } \\
\text { development } \\
\text {-Technology } \\
\text { revolution }\end{array}$ & $\begin{array}{l}\text {-Vicious } \\
\text { circle of } \\
\text { economy } \\
\text {-Competitive } \\
\text { industry by } \\
\text { overseas } \\
\text { companies } \\
\text {-The } \\
\text { possibility of } \\
\text { a 'life-cycle' } \\
\text { effect by } \\
\text { foreign } \\
\text { enterprises } \\
\text { in Ireland }\end{array}$ & $\begin{array}{l}\text {-The highest } \\
\text { unemployment } \\
\text { rate } \\
\text {-Enterprise as } \\
\text { the main } \\
\text { driver } \\
\text { of national } \\
\text { competitive- } \\
\text { ness } \\
\text {-Industry } \\
\text { development } \\
\text { by foreign } \\
\text { enterprise }\end{array}$ & $\begin{array}{l}\text {-ICTs and } \\
\text { biotechnology } \\
\text { as the key } \\
\text { drivers } \\
\text {-IFSC as the } \\
\text { primary source } \\
\text { of Ireland's } \\
\text { competitive- } \\
\text { ness }\end{array}$ \\
\hline $\begin{array}{c}\text { Developing a } \\
\text { National } \\
\text { Vision }\end{array}$ & $\begin{array}{l}\text {-Industrialized } \\
\text { Korea on the } \\
\text { basis of } \\
\text { 'Jarip- } \\
\text { Gyongje' } \\
\text {-Complete } \\
\text { 'Jarip- } \\
\text { Gyongje' by } \\
\text { the early } \\
\text { 1980s }\end{array}$ & $\begin{array}{l}\text { Acomplishing } \\
\text { 'Jarip- } \\
\text { Gyongje' as } \\
\text { self- } \\
\text { supportive } \\
\text { economic } \\
\text { system }\end{array}$ & $\begin{array}{l}\text {-Establishing } \\
\text { and } \\
\text { sustaining } \\
\text { 'Jarip- } \\
\text { Sungjang' }\end{array}$ & $\begin{array}{l}\text {-Rebuilding } \\
\text { Ireland as a } \\
\text { cohesive } \\
\text { society with } \\
\text { sustainable } \\
\text { employment } \\
\text { growth and } \\
\text { competitive- } \\
\text { ness }\end{array}$ & $\begin{array}{l}\text {-Building a } \\
\text { self-sustained } \\
\text { development } \\
\text { for } \\
\text { competitive- } \\
\text { ness and } \\
\text { employment } \\
\text { growth }\end{array}$ & $\begin{array}{l}\text {-Sustaining the } \\
\text { virtuous circle } \\
\text { of } \\
\text { achievements } \\
\text { in economic } \\
\text { and social } \\
\text { inclusions in } \\
2000 \text { s }\end{array}$ \\
\hline $\begin{array}{c}\text { Creating a } \\
\text { Nation- } \\
\text { Brand } \\
\text { Vision }\end{array}$ & $\begin{array}{l}\text {-Industrialized } \\
\text { Korea based } \\
\text { on Export } \\
\text { first } \\
\text { Principle }\end{array}$ & $\begin{array}{l}\text {-Industrialized } \\
\text { Korea based } \\
\text { on Heavy and } \\
\text { Chemical } \\
\text { Industries } \\
\text { and } \\
\text { Export first } \\
\text { Principle }\end{array}$ & $\begin{array}{l}\text {-Science and } \\
\text { Technology- } \\
\text { advanced } \\
\text { Korea } \\
\text {-Nordpolitik } \\
\text {-Segyehwa }\end{array}$ & $\begin{array}{l}\text {-Ireland as } \\
\text { the world's } \\
\text { leading } \\
\text { international } \\
\text { financial } \\
\text { services hub }\end{array}$ & $\begin{array}{l}\text {-Ireland } \\
\text { sustaining } \\
\text { long-run } \\
\text { competitive- } \\
\text { ness through } \\
\text { enterprise } \\
\text { innovation }\end{array}$ & $\begin{array}{l}\text {-Ireland as the } \\
\text { World Centre } \\
\text { of Research } \\
\text { Excellence } \\
\text {-Sustaining } \\
\text { IFSC Brand }\end{array}$ \\
\hline
\end{tabular}

Nation brand vision (NBV) refers to a desired future for the people and characterizes strategic visions that are catagorised by informed, shared, competitive, innovative and enabling visions. When President Park and his Government in the ESTI-I period created Korea-Brand Vision building 'Industrialized Korea based on Export first Principle,' the principle in picturing the brand vision was founded on building a new Korea for the Korean people. The Korea-Brand Vision was created with determined insight and through informed decisions by the national leader and with strategic analysis by the Korean Government. When the IFSC-brand project in 1987 was started, the Prime Minister envisaged the Ireland-Brand Vision as rebuilding Ireland as the world's leading international financial services hub. The Ireland-brand vision based on the IFSC-brand project has proved that the national leader has chiefly put the emphasis on attracting the talented and young Irish people who previously emigrated and on taking a competitive position in the international financial services market through taking informed decisions. 
With an informed vision, the Korea-Brand Vision and the Ireland-Brand Vision are distinguished by competitive and innovative visions continually aiming for new ways to gain competitive advantage. Over the periods of ESTI-branding, Korea has put the emphasis on promoting 'Industrialized Korea' based on the 'Export first Principle' and 'Science and Technology-based industries,' which manifests environment-creating brand visions that build competitiveness in global markets. The Ireland-Brand Vision (IBV) in building the IFSC, a specific branding project, has provided economic competitiveness for Ireland over a short period (FIEK-I). From FIEK-II, IBV has guided Ireland to building national competitiveness with enterprise development through innovation. During the FIEK-III period, IBV envisioned Ireland as a sustained nation with long-run competitiveness through knowledge-based enterprises and industries.

Nation brand visions are now compared in two nations that have shared and enabling visions. Korea branding during ESTI-I was started with a determined belief in building a new Korea. The President and Government took the initiative in envisioning an 'Industrialized Korea based on Export first Principle.' In particular, President Park initiated the development of the principles of 'Export First' and 'Industrialization' for the Korean People and led Korea-branding with his future-forward intuition and optimistic spirit. A top-down approach based on the national leader and Government was continued in creating the Korea-Brand Visions during the ESTI periods. Meanwhile, Ireland Branding took a bottom-up approach. The NESC, which was organized by the Government leader and its social partners (i.e. representatives of trade unions, employers, farmers' organisations, NGOs, key government departments and independent experts) has since 1973 taken the primary role in analysing Ireland's economic and social developments, and building both national visions and brand visions. Based on a vision shared by the NESC, the Prime Minister and the Government, during the FIEK-I, established the IFSC-brand vision. Since FIEK-II, Forfás has supported the Ireland-Brand Vision. Over the period of FIEK-III, the Ireland-Brand Vision was created by the concerted efforts of the NESC, Forfás and the Department of the Taoiseach.

With the characteristics of strategic visions (Table 77), Korea and Ireland distinguished coherent nation-brand visions based on top-down or bottom-up approaches. These were upheld and strengthened from the beginning of the branding process, despite different governments. Korea and Ireland created brand visions that were closely aligned with their national visions. 
Table 77 The characteristics of strategic nation-brand visions in Korea and Ireland

\begin{tabular}{|c|c|c|c|c|c|c|}
\hline & \multicolumn{3}{|c|}{ Creation of Korea-Brand Visions } & \multicolumn{3}{|c|}{ Creation of Ireland-Brand Visions } \\
\hline & ESTI-I & ESTI-II & ESTI-III & FIEK-I & FIEK-II & FIEK-III \\
\hline $\begin{array}{l}\text { Taking } \\
\text { top-down or } \\
\text { bottom-up } \\
\text { approach }\end{array}$ & $\begin{array}{c}\text { Top-down } \\
\text { by } \\
\text { the President } \\
\& \\
\text { Government }\end{array}$ & $\begin{array}{l}\text { Top-down } \\
\text { by } \\
\text { the President } \\
\& \\
\text { Government }\end{array}$ & $\begin{array}{c}\text { Top-down } \\
\text { by } \\
\text { the President } \\
\& \\
\text { Government }\end{array}$ & $\begin{array}{l}\text { Bottom-up } \\
\text { by } \\
\text { the NESC } \\
\text { \& Prime } \\
\text { Minister }\end{array}$ & $\begin{array}{l}\text { Bottom-up by } \\
\text { the NESC, } \\
\text { Forfás \& } \\
\text { Department } \\
\text { of Taoiseach }\end{array}$ & $\begin{array}{l}\text { Bottom-up by } \\
\text { the NESC, } \\
\text { Forfás, ICSTI \& } \\
\text { Department } \\
\text { of Taoiseach }\end{array}$ \\
\hline $\begin{array}{l}\text { Types of a } \\
\text { nation-brand } \\
\text { vision }\end{array}$ & $\begin{array}{l}\text { Informed, } \\
\text { competitive, } \\
\text { innovative }\end{array}$ & $\begin{array}{l}\text { Informed, } \\
\text { competitive, } \\
\text { innovative }\end{array}$ & $\begin{array}{l}\text { Informed, } \\
\text { competitive, } \\
\text { innovative }\end{array}$ & $\begin{array}{c}\text { Shared, } \\
\text { informed, } \\
\text { competitive, } \\
\text { innovative }\end{array}$ & $\begin{array}{l}\text { Shared, } \\
\text { enabling, } \\
\text { informed, } \\
\text { competitive, } \\
\text { innovative }\end{array}$ & $\begin{array}{l}\text { Shared, } \\
\text { enabling, } \\
\text { informed, } \\
\text { competitive, } \\
\text { innovative }\end{array}$ \\
\hline
\end{tabular}

\subsubsection{SETTING A NATION-BRAND GOAL (S-NBG)}

Setting a nation-brand goal (S-NBG) is considered to be a contextual phase influencing the sustainable competitiveness of nations. In line with the environmentcreating mechanism and the nation-branding context, the nation-brand goal (NBG) is set by reflecting a nation-brand vision. To set up a nation-brand goal, it is necessary to analyse national resources and the external environment related to branding. Branding actors play active roles to decide targeted goals anticipating a nation's future change.

Korea-brand goals (Table 78) and Ireland-brand goals (Table 79) were developed by reflecting nation brand visions and analysing national resources and the external environment related to branding. The Korea-brand vision (KBV) over ESTI-I has been described as building an 'Industrialized Korea based on Export first Principle.' National branding resources have been analysed with industry, science and technology development, export products. Simultaneously, the branding environment has been investigated in terms of dependency on US and Japan markets, industrialized economies' market expansions and international trade volumes, which have provided prospects with market opportunities through the expansion of secondary industries and improvement of enterprises' competitiveness in international markets. In respect of the brand vision and strategic analysis of branding resources and environment, the branding objective of building 'Export Korea' has been articulated. In particular, brand goal reflects the export goal of targeting a certain export volume and developing export products by the secondary industries. Coming to ESTI-II, in line with the brand vision of the building Korea on the basis of 'Heavy and Chemical Industrialization' along with 'Export first Principle', the market trend with intensive technology and high value-added industrial structure and market competition in HCIs have been mainly considered to be branding environment and resources. The Koreabrand goal (KBG) focused on accelerating 'Export Korea' along with the strategic expansion of the HCIs' development. Nation brand vision of building 'Science and Technology-advanced Korea in 2000s' has been boosted by analysing the contribution of science and technology to Korea's economic growth and the neccessity to promote science 
and technology-based industry development. Based on the Korea-brand vision and analysis, the Korea-brand goal during ESTI-III was articulated for speeding up science and technology-led HCIs and developing science and technology-intensive industries for Export Korea, particularly aiming to accomplish 'Science and Technology-advanced Korea' by ranking in the world top ten by the year 2000 and aiming to be a world leader in high-technology products.

Table 78 Setting Korea-brand goals

\begin{tabular}{|c|c|c|}
\hline \multirow{3}{*}{ ESTI-I } & $\begin{array}{c}\text { Reflecting a } \\
\text { Nation-Brand } \\
\text { Vision }\end{array}$ & -Building 'Industrialized Korea based on Export first Principle' \\
\hline & $\begin{array}{c}\text { Analysing } \\
\text { Branding } \\
\text { Resources and } \\
\text { Environment }\end{array}$ & $\begin{array}{l}\text {-Poor endowment of natural resources } \\
\text {-Small sized domestic market } \\
\text {-Low enterprises competency } \\
\text {-Low investment for R\&D } \\
\text {-Primary industry as main export products } \\
\text {-High dependence on Japan markets } \\
\text {-The world industrialized economies' market expansions } \\
\text { (from USA into Western Europe) } \\
\text {-International trade volume enlargement } \\
\text {-The possibility of expansion of the secondary industry } \\
\text { (mining and manufacturing sectors) and improvement of enterprises' } \\
\text { competitiveness in the international markets }\end{array}$ \\
\hline & $\begin{array}{c}\text { Setting a } \\
\text { Nation-Brand } \\
\text { Goal }\end{array}$ & $\begin{array}{l}\text {-Building Export Korea } \\
\text { :Export goal counting an average amount of US } \$ 140 \text { million during the first } \\
\text { FYP } \\
\text { :In } 1966 \text { export products replaced by the secondary industry up to } 57 \text { per cent } \\
\text { instead of the primary one }\end{array}$ \\
\hline \multirow[t]{2}{*}{$\begin{array}{l}\text { ESTI- } \\
\text { II }\end{array}$} & $\begin{array}{c}\text { Reflecting a } \\
\text { Nation-Brand } \\
\text { Vision }\end{array}$ & $\begin{array}{l}\text {-'Industrialized Korea based on Heavy and Chemical industries and } \\
\text { Export first Principle' }\end{array}$ \\
\hline & $\begin{array}{c}\text { Analysing } \\
\text { Branding } \\
\text { Resources and } \\
\text { Environment }\end{array}$ & $\begin{array}{l}\text {-Market share as per product and country categories } \\
\text {-Market demands on existing and new products } \\
\text {-Competitive nations; importing nations } \\
\text {-Export dependence on USA and Japan markets } \\
\text {-World trading environment } \\
\text {-World industry structure } \\
\text {-Newly Industrialized Countries (NICs) affecting light industry market and } \\
\text { intensifying market competition in HCIs } \\
\text {-Possibilities to exploit new markets such as China, Eastern Europe, Central } \\
\text { and South America, and Africa }\end{array}$ \\
\hline
\end{tabular}




\begin{tabular}{|c|c|c|}
\hline & $\begin{array}{c}\text { Setting a } \\
\text { Nation-Brand } \\
\text { Goal }\end{array}$ & $\begin{array}{l}\text {-Establishing HCIs and accelerating Export Korea } \\
\text { :Manufacturing sector in the secondary industry is to increase up to } 133.2 \text { per } \\
\text { cent and HCIs will constitute } 40.5 \text { per cent of manufacturing sector in } 1976 \\
\text { :Long-term export goals indicating that manufacturing sector for export } \\
\text { targeted } 28.4 \text { per cent compared to other sectors and HCIs products in } \\
\text { manufacturing sector considered } 51.5 \text { per cent between } 1972 \text { and } 1976\end{array}$ \\
\hline \multirow{3}{*}{$\begin{array}{c}\text { ESTI- } \\
\text { III }\end{array}$} & $\begin{array}{c}\text { Reflecting a } \\
\text { Nation-Brand } \\
\text { Vision }\end{array}$ & -Science and technology-advanced Korea \\
\hline & $\begin{array}{c}\text { Analysing } \\
\text { Branding } \\
\text { Resources and } \\
\text { Environment }\end{array}$ & $\begin{array}{l}\text {-Export competition getting intensified } \\
\text {-Industrialized nations in 1980s will increase import amount in } \\
\text { manufacturing products } \\
\text {-Necessity of enlarging export market and reinforcing export market share } \\
\text { through qualified manufacturing products } \\
\text {-Investment in science and technology } \\
\text {-Necessity to accelerate to develop technology-based industries and to } \\
\text { concentrate on industrial restructuring }\end{array}$ \\
\hline & $\begin{array}{c}\text { Setting a } \\
\text { Nation-Brand } \\
\text { Goal }\end{array}$ & $\begin{array}{l}\text {-Accelerating technology-led HCIs and developing technology-intensive } \\
\text { industries for Export Korea } \\
\text { :Accomplishing 'Science and Technology-advanced Korea' by ranking as the } \\
\text { world top ten by the year } 2000 \text {. In particular, targeting to position as a world } \\
\text { leader in high-technology products }\end{array}$ \\
\hline
\end{tabular}

Ireland-brand goals have been built by reflecting the country's nation-brand visions. The Ireland-brand vision (IBV) over the FIEK-I period was focused on rebuilding Ireland to become a world's international financial service hub. In line with IBV, preliminary analysis of national sources of competitive advantage were done by the NESC and market opportunities in expanding FDI promotion from the US and the Far East market were analysed. Expecting a combined approach (i.e. FI Promotion) to integrating FDI promotion into Ireland's industry development promotion (IP), the IFSC branding project was targeted as the Ireland-brand goal for FIEK-I. Coming to the FIEK-II period, Ireland established a brand vision sustaining long-run competitiveness through enterprise and innovation. Believing that trade had been increasingly linked to FDI and that FDI promotion would be very competitive within European economies, Forfás insisted on establishing an innovative and competitive enterprise sector by integrating Irish-owned and foreign-owned enterprises into a concept of an enterprise sector. Aiming to reduce the unemployment rate, to increase living standards and to raise the quality of life of all of those living in Ireland, Forfás presented a long-term framework for enterprise development promotion over the following fifteen years. During FIEK-III, Ireland preserved a general brand vision positioning Ireland as a Knowledge-based Society based on the World Centre of Research Excellence and a specific vision maximizing the level of the sustainable IFSC brand in Ireland. In line with the Ireland-brand vision, Forfás believed that global conditions for technological change (especially the ICT sector) would significantly affect the Irish economy, and considered ebusiness to be a main driver for FI promotion and national economic development. In line 
with enterprise competitiveness, Forfás highlighted that productivity in the foreign-owned manufacturing sector had underpinned the competitiveness of the entire industry segment and that sectoral concentration had increased in the higher technology sectors over recent years. Underlining that increased productivity would be a fundamental basis for the sustainable competitiveness of enterprises and for stable high-income employment, Forfás set the Ireland's brand goals specifying the conditions that would secure foreign companies' value-added activities and creating additional higher value-added jobs in the internationally-traded sector. In particular, to sustain the competitiveness of the IFS industry in Ireland, the Department of the Taoiseach set up a brand goal to build the positive "image" of the IFSC, promoting Ireland as a highly desirable world financial services location.

Table 79 Setting Ireland-brand goals

\begin{tabular}{|c|c|c|}
\hline \multirow{3}{*}{ FIEK-I } & $\begin{array}{c}\text { Reflecting a } \\
\text { Nation-Brand } \\
\text { Vision }\end{array}$ & -Rebuilding Ireland as the world's leading international financial services hub \\
\hline & $\begin{array}{c}\text { Analysing } \\
\text { Branding } \\
\text { Resources and } \\
\text { Environment }\end{array}$ & $\begin{array}{l}\text {-GDP per capita; National Debt; Unemployment rate; Net emigration } \\
\text {-Comparative advantage in industry } \\
\text {-International financial service industry } \\
\text {-Investment projects by new and expanding overseas companies from the US } \\
\text { and Far East markets }\end{array}$ \\
\hline & $\begin{array}{c}\text { Setting a } \\
\text { Nation-Brand } \\
\text { Goal }\end{array}$ & $\begin{array}{l}\text {-Promoting overseas investment (i.e. FDI Promotion) with industrial } \\
\text { development promotion (i.e. IP) and integrating them into a combined } \\
\text { approach for Irish economy } \\
\text { :Creating approximately } 16,500 \text { jobs through FDI promotion and, } \\
\text { in particular, } 7,500 \text { jobs through IFSC project over the next 3-4 years }\end{array}$ \\
\hline \multirow[b]{3}{*}{$\begin{array}{c}\text { FIEK- } \\
\text { II }\end{array}$} & $\begin{array}{c}\text { Reflecting a } \\
\text { Nation-Brand } \\
\text { Vision }\end{array}$ & -Ireland sustaining long-run competitiveness through enterprise innovation \\
\hline & $\begin{array}{c}\text { Analysing } \\
\text { Branding } \\
\text { Resources and } \\
\text { Environment }\end{array}$ & $\begin{array}{l}\text {-The share of employment in various service categories in Ireland } \\
\text {-Available market niches in services sector } \\
\text {-Slow and uncertain progress of Ireland's main markets } \\
\text {-The degree of intensity in market competition for Irish producers } \\
\text {-Inter-relations between trade and FDI } \\
\text {-Increased competition attracting FDI market }\end{array}$ \\
\hline & $\begin{array}{c}\text { Setting a } \\
\text { Nation-Brand } \\
\text { Goal }\end{array}$ & $\begin{array}{l}\text {-Establishing sustainable employment and competitive enterprise sector } \\
\text { :Inward investment achieving } 9,000 \text { gross jobs per annum on average over } \\
\text { the period of } 1990 \mathrm{~s} \\
\text { :Halving the present rate of unemployment to approximately } 6 \text { per cent by } \\
2010 \\
\text { :Reducing the number of long-term unemployed from } 127,000 \text { in } 1995 \text { to no } \\
\text { more than } 50,000 \text { by } 2010 \\
\text { :Increasing living standards, in GNP per capita, to achieve average EU-15 } \\
\text { levels, compared with } 65.2 \text { per cent of the EU-15 average in } 1995 \\
\text { :Raising the quality of life of all of those living in Ireland }\end{array}$ \\
\hline
\end{tabular}




\begin{tabular}{|c|c|c|}
\hline \multirow{3}{*}{$\begin{array}{l}\text { FIEK- } \\
\text { III }\end{array}$} & $\begin{array}{c}\text { Reflecting a } \\
\text { Nation-Brand } \\
\text { Vision }\end{array}$ & $\begin{array}{l}\text {-Positioning Ireland as a World Centre of Research Excellence } \\
\text {-Maximizing competitiveness of IFSC brand }\end{array}$ \\
\hline & $\begin{array}{c}\text { Analysing } \\
\text { Branding } \\
\text { Resources and } \\
\text { Environment }\end{array}$ & $\begin{array}{l}\text {-Global condition with technological change (especially ICT sector) } \\
\text {-E-business as main driver for FI promotion and national economic } \\
\text { development } \\
\text {-The sectoral gap between Irish-owned and foreign-owned manufacturing } \\
\text { sectors in employment and productivity } \\
\text {-The long-term viability of the IFS industry in Ireland in transition of tax } \\
\text { regime and political will for development }\end{array}$ \\
\hline & $\begin{array}{c}\text { Setting a } \\
\text { Nation-Brand } \\
\text { Goal }\end{array}$ & $\begin{array}{l}\text {-Increasing productivity } \\
\text { :Setting up a competitive enterprise environment for foreign companies' } \\
\text { value-added activities } \\
\text { :Creating additional higher value-added jobs in the internationally traded } \\
\text { sector (manufacturing and internationally traded services) from 310,000 in } \\
1998 \text { to } 400,000 \text { in } 2010 \\
\text {-Sustaining competitiveness of IFS industry } \\
\text { :Building the positive "image" of the IFSC and promoting Ireland as a } \\
\text { financial services location }\end{array}$ \\
\hline
\end{tabular}

Korea's and Ireland's governments have played key roles in envisaging brand goals. In the case of Korea's branding, the Economic Planning Board (EPB) fixed Korea-brand goals with the cooperation of government ministries throughout the ESTI periods. In particular, the Ministry of Commerce and Industry initiated the setting of export goals. The Ministry of Science and Technology - in conjunction with research institutes and social partners - created the brand goal during ESTI-III. Ireland-brand goals were envisaged through the concerted efforts of the Government and its social partners. The Department of the Taoiseach mainly set the IFSC-brand goal. Since FIEK-II in particular, Forfás has been actively involved in creating the Ireland-Brand Goal. Korea's and Ireland's brand goals have been explained by some quantitative or qualitative sizes and temporal scope.

Table 80 Branding actors in Korea-brand goals (KBG) and Ireland-brand goals (IBG)

\begin{tabular}{|c|l|l|}
\hline \multirow{5}{*}{$\begin{array}{c}\text { Branding } \\
\text { Actors }\end{array}$} & \multicolumn{1}{|c|}{ S-KBG } & \multicolumn{1}{|c|}{ S-IBG } \\
\cline { 2 - 3 } & $\begin{array}{l}\text { EPB, government ministries (in particular, } \\
\text { Ministry of Commerce and Industry) }\end{array}$ & $\begin{array}{l}\text { Department of the Taoiseach, government } \\
\text { ministries, social partners }\end{array}$ \\
\cline { 2 - 3 } & $\begin{array}{l}\text { EPB, government ministries (in particular, government ministries, social } \\
\text { partners, Department of the Taoiseach }\end{array}$ \\
\cline { 2 - 3 } & $\begin{array}{l}\text { Ministry of Science and Technology), } \\
\text { social partners }\end{array}$ & $\begin{array}{l}\text { Forfás, Department of the Taoiseach, } \\
\text { government ministries, social partners }\end{array}$ \\
\hline
\end{tabular}




\subsubsection{DEVELOPING A NATION-BRAND STRATEGY (D-NBS)}

A nation-brand strategy (NBS) is about the intended direction of brand positioning. Considering NBS as the guiding light for a country's strategy and direction, developing a nation-brand strategy (D-NBS) needs to be closely linked to the national strategy for national development. In developing NBS, branding actors and activities (i.e. how a nationbrand positioning is crafted and who are involved in the activities) are important elements. In particular, through the process of developing NBS, it is important to define how NBS maintains consistency with a nation-brand goal and a national strategy, and how NBS is developed through restructuring internal resources and the external market environment.

Nation brand strategies of both Korea (Table 81) and Ireland (Table 82) were embodied in national development strategies and concretized by the strategy for ESTI or FIEK promotions. The Korean Government established Five-Year Plans (FYPs) to suit the national development strategy. Throughout the FYPs, nation brand goals (NBG) in terms of their three aspects - 'Export Korea', 'Science \& Technology-advanced Korea' and 'Industrialized Korea' - have been concretized by Korea-brand strategies, i.e. strategic directions for ESTI-brand. During ESTI-I, FYPs were identified to develop infrastructure and principal industries for production systems, and to promote export, science and technology. Within FYPs, ESTI-brand strategies were envisaged for export and industry development promotions along with science and technology promotion. To achieve the nation brand goal, the ESTI-brand strategy put the emphasis on developing infrastructure and science and technology base for export industry development and for export market promotion. Coming to ESTI-II, FYPs invigorated advanced industrial development by focusing on HCIs along with expanding the science and technology base and export promotion. In promoting export, science \& technology-led HCIs promotion was an important pillar of FYPs. The Korea-brand goal (KBG) over the ESTI-III was connected to develop the Korea-brand strategy by promoting investment in science and technology, and by intensifying science and technology innovation. In particular, it was to strengthen enterprise development based on high-tech and knowledge-based industrial development and to promotion economic openness and globalization based on export market diversification and international cooperation. Moreover, it reinforced growth potentiality based on science, technology and creativity, expanding export markets through enterprises' initiatives and economic cooperation.

Table 81 Developing Korea-brand strategies (D-KBS)

\begin{tabular}{|c|c|l|}
\hline \multirow{3}{*}{ ESTI-I } & $\begin{array}{c}\text { Reflecting a } \\
\text { Nation-Brand } \\
\text { Goal }\end{array}$ & $\begin{array}{l}\text {-Building Export Korea } \\
\text { :Export goal counting an average amount of US \$140million during the first } \\
\text { FYP } \\
\end{array}$ \\
\hline
\end{tabular}




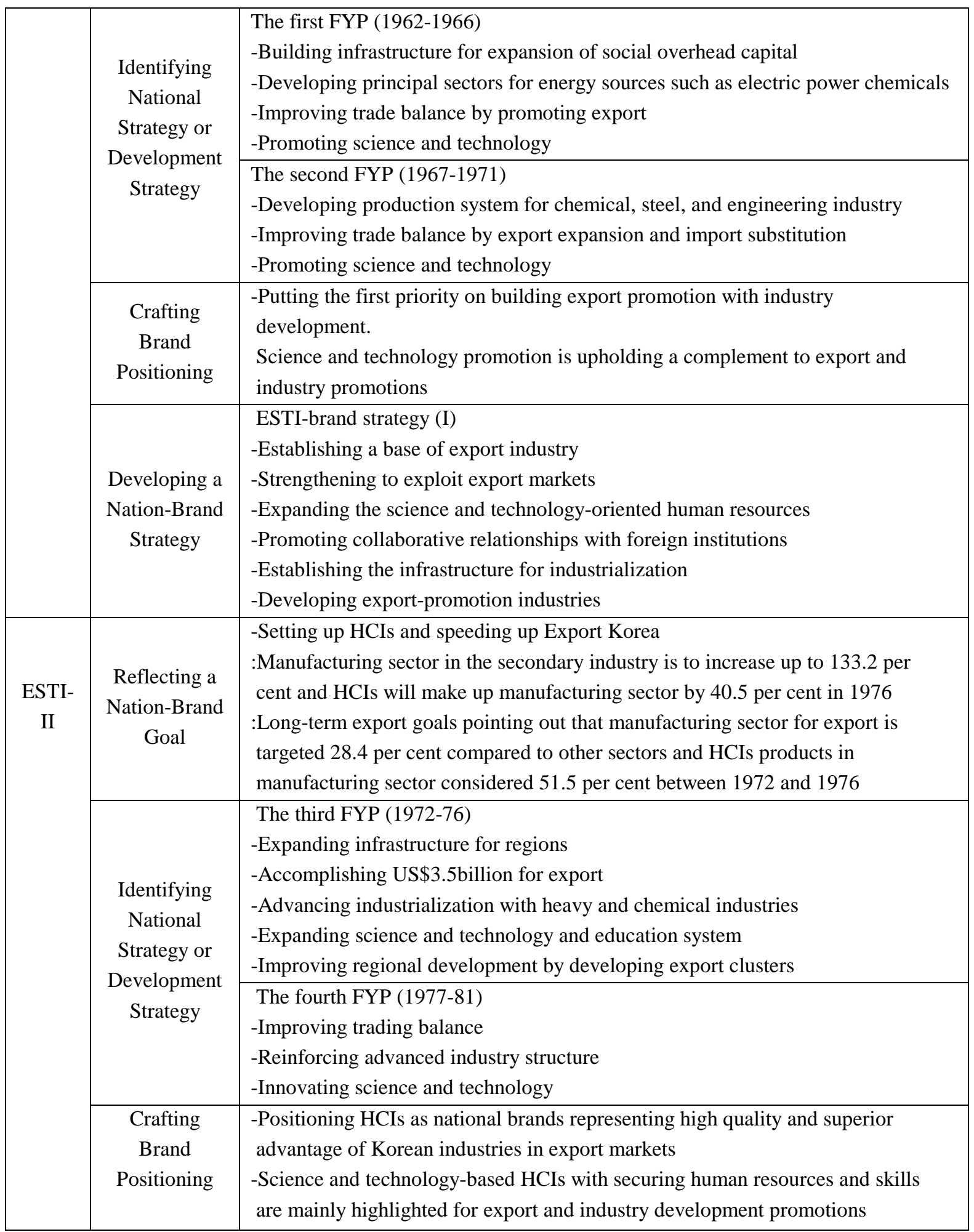




\begin{tabular}{|c|c|c|}
\hline & $\begin{array}{l}\text { Developing a } \\
\text { Nation-Brand } \\
\text { Strategy }\end{array}$ & $\begin{array}{l}\text { ESTI-brand strategy (II) } \\
\text {-Expanding export industry \& products } \\
\text {-Diversifying export markets } \\
\text {-Improving export supporting system } \\
\text {-Creating and maintaining special accounts for export promotion } \\
\text {-Promoting general trading company } \\
\text {-Promoting industrial technology for HCIs } \\
\text {-Promoting knowledge-intensive industry and technology innovation } \\
\text {-Promoting HCIs as strategic export industries } \\
\text {-Securing engineers and skilled workers }\end{array}$ \\
\hline \multirow[t]{5}{*}{$\begin{array}{c}\text { ESTI- } \\
\text { III }\end{array}$} & $\begin{array}{l}\text { Reflecting a } \\
\text { Nation-Brand } \\
\quad \text { Goal }\end{array}$ & $\begin{array}{l}\text {-Accelerating technology-led HCIs \& developing technology-intensive } \\
\text { industries for Export Korea } \\
\text { :Accomplishing 'Science and Technology-advanced Korea' by ranking as the } \\
\text { world top ten by the year } 2000 . \text { In particular, targeting to position as the world } \\
\text { leader in high-technology products }\end{array}$ \\
\hline & \multirow{3}{*}{$\begin{array}{l}\text { Identifying } \\
\text { National } \\
\text { Strategy or } \\
\text { Development } \\
\text { Strategy }\end{array}$} & $\begin{array}{l}\text { The fifth FYP (1982-86) } \\
\text {-Solidifying economic stabilizing system and establishing a base for a self- } \\
\text { sustaining growth } \\
\text { :Promoting investment on technology and enterprise system } \\
\text { :Increasing export amount prominently } \\
\text {-Reducing technology and competitiveness gaps with advanced countries } \\
\text { :Promoting market competition for enterprise environment based on autonomy } \\
\text { and creativity } \\
\text { :Intensifying technology innovation } \\
\text { :Strengthening enterprise competitiveness by promoting product parts industry }\end{array}$ \\
\hline & & $\begin{array}{l}\text { The sixth FYP (1987-91) } \\
\text {-Strengthening enterprise development based on autonomy and economic } \\
\text { inclusion } \\
\text { :Reinforcing high-tech and knowledge-based industry development } \\
\text {-Promoting economic openness and globalization } \\
\text { :Reinforcing export industry structure } \\
\text { :Diversifying export markets } \\
\text { :Accelerating international openness and internationalization } \\
\text { :Expanding international cooperation } \\
\text { :Promoting foreign direct investment of domestic enterprises }\end{array}$ \\
\hline & & $\begin{array}{l}\text { New Economy FYP (1993-1997) } \\
\text {-Reinforcing growth potentiality based on science, technology and creativity } \\
\text {-Expanding export markets through enterprises initiatives and economic } \\
\text { cooperation with developing nations } \\
\text {-Enhancing competitiveness for domestic and foreign enterprises }\end{array}$ \\
\hline & $\begin{array}{c}\text { Crafting } \\
\text { Brand } \\
\text { Positioning }\end{array}$ & $\begin{array}{l}\text {-Positioning 'Science and Technology-advanced Korea' } \\
\text {-Export and industry development promotions based on high value-added } \\
\text { Products }\end{array}$ \\
\hline
\end{tabular}




\begin{tabular}{|c|l|l|}
\hline & ESTI-brand strategy (III) \\
& -Expanding export structure with high value-added products \\
& -Diversifying with Segmented Markets \\
& -Building trade diplomatic relationships with segmented markets \\
Developing a & -Improving trading regulations and laws as international standard \\
Nation-Brand & -Expanding expenditure on human resources and R\&D \\
Strategy & -Establishing an enterprise-led technology innovation system \\
& -Restructuring HCIs and enterprises \\
& -Reinforcing international cooperation as to industry development \\
& -Supporting enterprises' international strategies \\
& -Innovating operation of industrial policy \\
\hline
\end{tabular}

Since 1987 the Irish Government and its social partners developed the Programmes (PNR, PESP, PCW and P2000) amounting to national development strategies and presenting strategic directions for economic and social developments in Ireland. The Programmes were aligned with Ireland-brand goals (IBG) and envisaged strategic directions for FIEK promotions. During FIEK-I, the Programme chiefly focused on stabilizing macroeconomic conditions on the one hand and, based on a sectoral approach, strengthening industrial development and FDI promotion on the other. Particularly, in line with IBG, the PNR articulated the project to create the IFSC in Dublin under the sectoral approach. Over this period, the FIEK-brand strategy comprised a FI promotion strategy combining FDI promotion with an industry development strategy, particulary formulating both place development and market promotion strategies for Dublin's IFSC project. Coming to FIEK-II, Ireland needed to build international competitive industries and continue to enlarge the extent of economic activity by overseas companies, targeting the main industrial sub-sectors such as electronics, engineering, software and financial services sectors. To establish sustainable employment and a competitive enterprise sector, the focus of FIEK-brand strategy (II) should be to concentrate on the key sector and market niches in which Ireland enjoys the greatest competitive advantage and to uphold enterprise innovation continuously and strengthen partnership for competitive enterprises. The Brand goal for the 2000s, i.e. increasing productivity and sustaining the competitiveness of the IFS industry, was envisaged in the FIEK-brand strategy (III), focusing on how to promote knowledge and innovation in overall enterprise development and encompassing the consolidation of the 'IFSC and Docklands' brand images which positioned Ireland as a world-class hub for international financial services. 
Table 82 Developing Ireland-brand strategies

\begin{tabular}{|c|c|c|}
\hline \multirow{4}{*}{ FEIK-I } & $\begin{array}{c}\text { Reflecting a } \\
\text { Nation-Brand } \\
\text { Goal }\end{array}$ & $\begin{array}{l}\text {-Promoting overseas investment (i.e. FDI Promotion) with industrial } \\
\text { development promotion (i.e. IP) and integrating them into a combined } \\
\text { approach for Irish economy } \\
\text { :Creating approximately } 16,500 \text { jobs through FDI promotion, in particular, } \\
7,500 \text { jobs through IFSC project over the next 3-4 years }\end{array}$ \\
\hline & $\begin{array}{l}\text { Identifying } \\
\text { National } \\
\text { Strategy or } \\
\text { Development } \\
\text { Strategy }\end{array}$ & $\begin{array}{l}\text { PNR (1987-1990) } \\
\text {-Generating job opportunities on a sectoral basis } \\
\text { :Reinforcing industrial development promotion } \\
\text { :Intensifying FDI promotion on a specialized basis }\end{array}$ \\
\hline & $\begin{array}{c}\text { Crafting } \\
\text { Brand } \\
\text { Positioning }\end{array}$ & $\begin{array}{l}\text {-FI promotion combining FDI promotion with industry development } \\
\text {-Dublin's IFSC }\end{array}$ \\
\hline & $\begin{array}{c}\text { Developing a } \\
\text { Nation-Brand } \\
\text { Strategy }\end{array}$ & $\begin{array}{l}\text { FIEK-brand strategy (I) } \\
\text {-Developing a site plan for Dublin's IFSC } \\
\text {-Concentrating on the sectors and markets with competitive advantage } \\
\text {-Maintaining the existing markets (e.g. USA, Europe) } \\
\text {-Placing a special emphasis on new markets (e.g. the Far East) } \\
\text {-Securing investment from key companies in targeted markets }\end{array}$ \\
\hline \multirow[t]{3}{*}{$\begin{array}{l}\text { FIEK- } \\
\text { II }\end{array}$} & $\begin{array}{c}\text { Reflecting a } \\
\text { Nation-Brand } \\
\text { Goal }\end{array}$ & $\begin{array}{l}\text {-Establishing sustainable employment and competitive enterprise sector } \\
\text { :Inward investment achieving 9,000 gross jobs per annum on average over the } \\
\text { period of } 1990 \mathrm{~s} \\
\text { :Halving the present rate of unemployment to approximately } 6 \text { per cent by } 2010 \\
\text { :Reducing the number of long-term unemployed from 127,000 in } 1995 \text { to no } \\
\text { More than 50,000 by } 2010 \\
\text { :Increasing living standards, in GNP per capita, to achieve average EU-15 } \\
\text { levels, compared with } 65.2 \text { per cent of the EU-15 average in } 1995 \\
\text { :Raising the quality of life of all of those living in Ireland }\end{array}$ \\
\hline & \multirow[t]{2}{*}{$\begin{array}{l}\text { Identifying } \\
\text { National } \\
\text { Strategy or } \\
\text { Development } \\
\text { Strategy }\end{array}$} & $\begin{array}{l}\text { PESP (1991-1993) } \\
\text {-Reducing long-term unemployment } \\
\text { :Building an international competitive industry } \\
\text { :Providing the supportive measures by macroeconomic policies, } \\
\text { infrastructural services, and specific programmes and incentives } \\
\text { :Maximizing the extent of economic activity by overseas companies } \\
\text { :Targeting the main industrial sub-sectors }\end{array}$ \\
\hline & & $\begin{array}{l}\text { PCW (1994-1996) } \\
\text {-Increasing employment and reducing unemployment } \\
\text { :Concentrating on the key sector and market niches in which Ireland has the } \\
\text { greatest competitive advantage } \\
\text { :Increasing the level of linkages between indigenous and foreign-owned } \\
\text { enterprises } \\
\text { :Setting the inward investment sub-programmes } \\
\text { :Creating an attractive and efficient infrastructure } \\
\text { :Establishing a competitive and stable business environment } \\
\text { :Promoting the development of new business }\end{array}$ \\
\hline
\end{tabular}




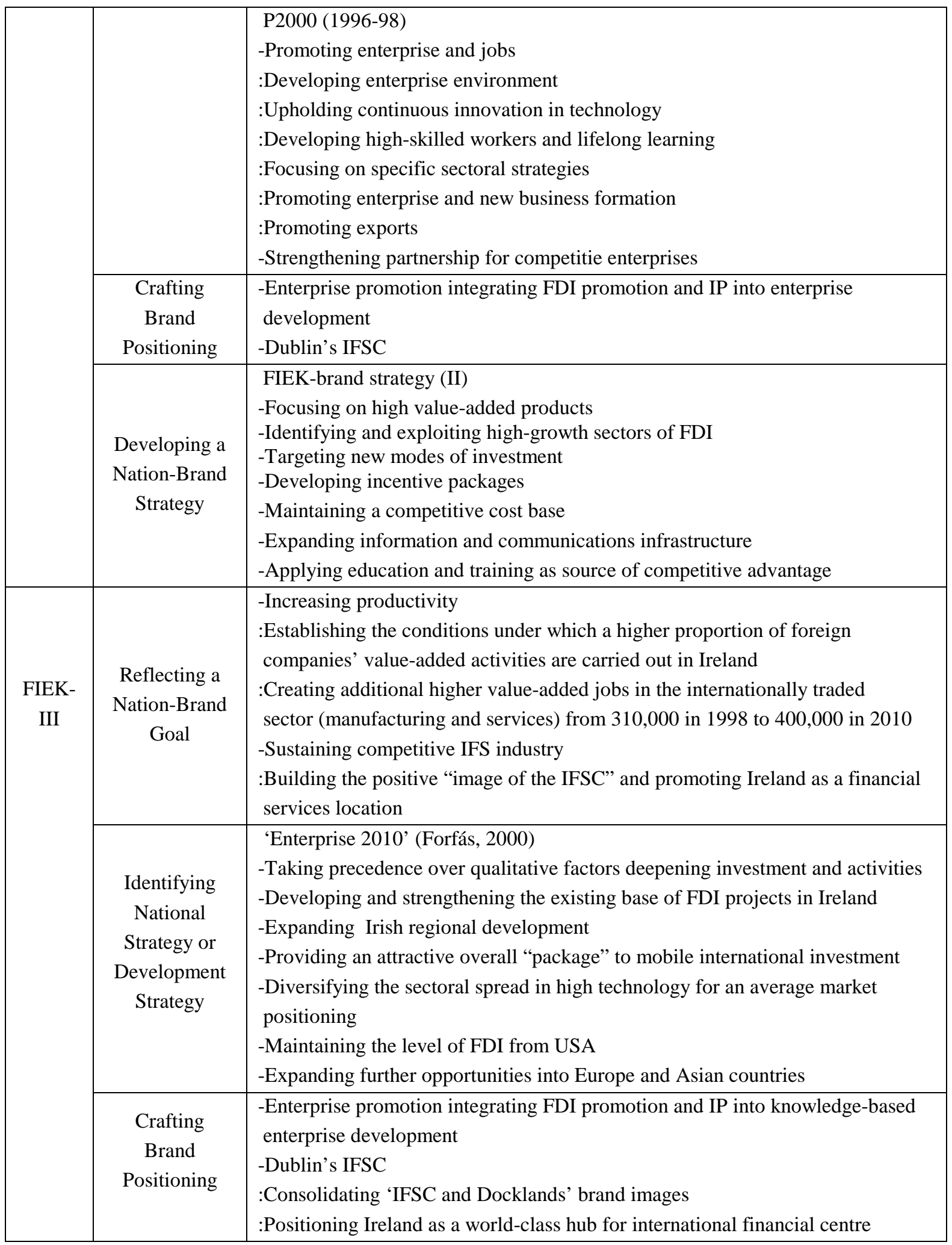




\begin{tabular}{|l|l|l|}
\hline & FIEK-brand strategy (III) \\
& -Developing and strengthening the existing base of FDI projects in Ireland \\
& -Maintaining the level of US FDI \\
& -Presenting an 'IFSC brand' \\
& -Taking precedence over qualitative factors deepening investment and activities \\
Developing a & -Diversifying the sectoral spread in high technology for optimum market \\
Nation-Brand & positioning \\
Strategy & -Comfirming the Docklands as the hub for the long-term development of the \\
& industry in Ireland \\
& -Encouraging front-office financial services companies to locate within the \\
& Docklands hub, close to the IFSC \\
& -Continuing to promote educational initiatives in the Docklands Area \\
& -Expanding the Irish regional development
\end{tabular}

Korea, throughout the periods of ESTI, created FYPs as national development strategies. FYPs have set strategic directions for export, science and technology, and industrial development promotions. Korea's ESTI-brand strategies were coherently developed with FYPs. With Korea-brand goals, they were concretized as to how to position brand attractions (i.e. Science \& Technology-led HCIs and high value-added industries) to export markets. The EPB, the Ministry of Commerce and Trade (Ministry of Trade and Industry since ESTI-II) and the Ministry of Science and Technolgy in conjugation with their social partners coming to ESTI-III were mainly involved in developing the Koreabrand strategy. Meanwhile, since 1987 Ireland has developed the Programmes for national development. These Programmes have mainly focused on improving employment while envisaging strategic directions for FDI, innovation and knowledge-based industrial development, and enterprise development promotions. Ireland's FIEK-brand strategies were coherently included in the Programmes. FIEK-brand strategies, with Ireland-brand goals, have shown how to position Ireland's competitive identities (i.e. IFSC, Innovative enterprise environment, Knowledge-based enterprise and industry) to FDI markets. Compared with developing the ESTI-brand strategy of Korea, the FIEK-brand strategy of Ireland was consistently developed through the concerted efforts by the Government and its social partners, aligning with policy recommentations or strategies from other government departments and agencies. 
Fig. 27 Developing Korea-brand strategy and Ireland-brand strategy

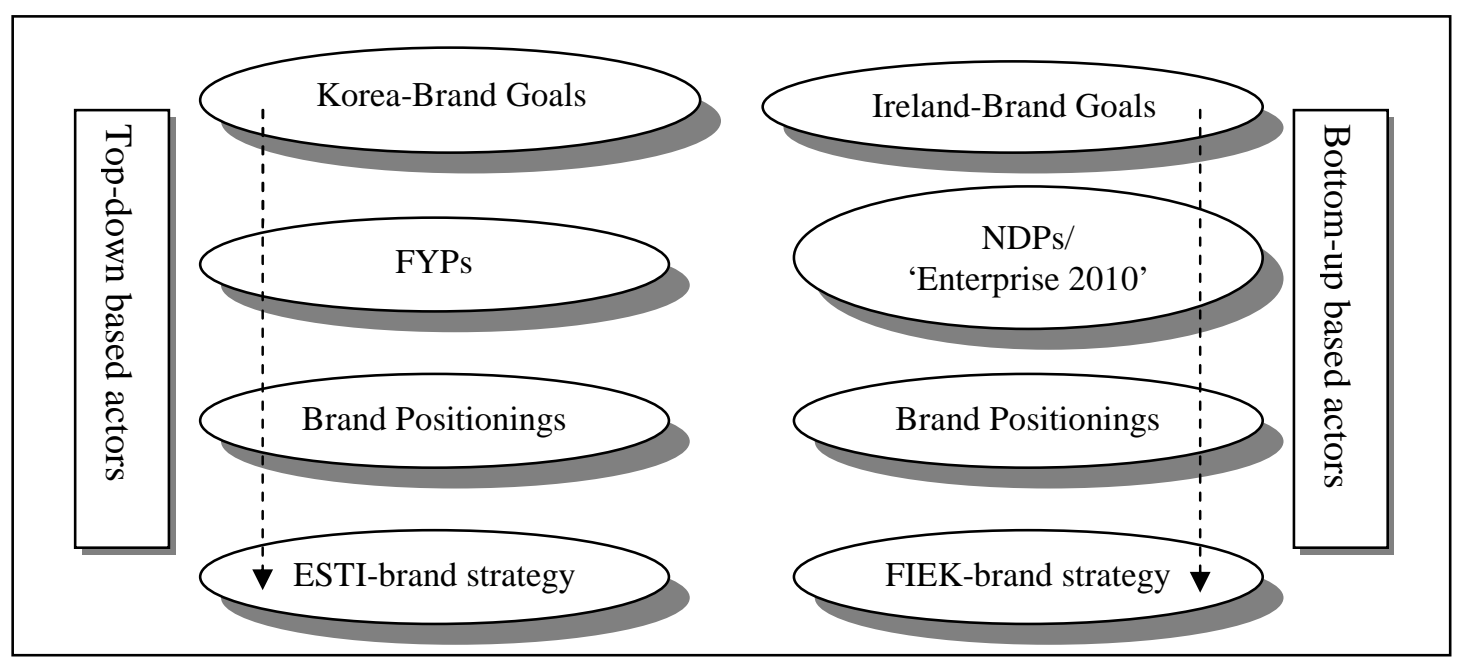

\subsubsection{OPERATING A NATION-BRAND STRATEGY (O-NBS)}

O-NBS is where a nation-brand strategy is put into practice and translated into national action, comprising a series of activities for creating and developing brand attraction and communicating that attraction to target markets. Operating NBS relies on integrating various components. Collaboration and coordination between branding actors (i.e. stakeholdership) mainly represent a performance measure for a nation brand's operating capability. In particular, government policies play a significant role in creating brand attraction and brand communication. Maintaining consistency of policy represents a nation's brand competency.

Korea's ESTI-brand strategy has been operated through the government policy that supports the promotion of exports, science, technology and industrial development. Ireland's FIEK-brand strategy also has been supported by government policy measures that promote FDI, industry and knowledge-based enterprises. Korea and Ireland have both focused on promoting science and technology-based (or knowledge-based) industrial development. However, they have targeted different target markets. Korea has focused on securing export markets, but Ireland has put the emphasis on promoting FDI. In operating the nation-brand strategy, both nations have identified and developed brand attractions and communicated these attractions toward differentiated but competitive target markets.

In creating and developing brand attraction, Korea over the periods of ESTI promotion (ESTI-P) (Table 83) focused on identifying and developing export products. The ESTI-P in 1960s, i.e. ESTI-P (I), operated through identifying and developing export products mainly relying on light industry. The ESTI-P in 1970s, i.e. ESTI-P (II), expanded export products by diversifying and qualifying light industry products. Moreover, it developed export products from HCIs by setting priorities to achieve comparable advantage (e.g. in machinery, electronics, shipbuilding) in HCIs and by strategically selecting iron and steel, nonferrous metals, and petrochemicals at optimal levels in line with allied industries. ESTI- 
P over the period from 1980s through 1990s, i.e. ESTI-P (III), was deployed by developing export products with high value-added products. Science and Technology-led HCIs and high-tech industries were created. During the periods of ESTI-P, Korea developed brand attractions by collaborating with advanced science and technology from abroad, establishing an export industry infrastructure, empowering export enterprises, and providing incentives. Particularly coming to ESTI-P (III), it was important to establish enterprise-led technology innovation systems and to reinforce market-led technology development systems. In developing its brand attractions, Korea developed brand communication with export markets. Brand communication in ESTI-P (I) was started by exploiting export markets - relying on US and Japanese markets - delivering Korea and its products images, and establishing trade relations. Coming to ESTI-P (II), export markets were expanded and diversified in the EC, Middle East and Eastern Europe, reducing USA market dependence while maintaining the Japan market. Korea and its product images were delivered through market exploitation by the salespersons board of KOTRA. Communication tools were expanded. Trade relations were reinforced by exchanging human resources and skills, and by hosting symposiums for industrial cooperation. ESTI-P over the 1980s and through the 1990s was carried out by focusing on building Korea's image as a country taking responsibility for the international trade environment, positioning Korea as a major player with the initiative to trade and cooperate internationally. Export markets were diversified and segmented. The overseas marketing infrastructure was reinforced with overseas exhibitions and Korea image PR. Trade diplomatic relationships were strengthened in the segmented markets.

Table 83 Operating Korea-brand strategies (O-KBS)

\begin{tabular}{|c|c|c|}
\hline \multirow[t]{2}{*}{ ESTI-I } & $\begin{array}{l}\text { Identifying and } \\
\text { developing } \\
\text { brand identities }\end{array}$ & $\begin{array}{l}\text {-Establishing public and private organizations (KOTRA, KIST) } \\
\text {-Expanding to 'Export Promotion Expansion Monthly Meeting' (1965) } \\
\text {-Providing incentives for export enterprise and industries } \\
\text {-Identifying and developing export products } \\
\text {-Collaborating with foreign advanced science and technology (Japan, } \\
\text { USA) } \\
\text {-Establishing the base of export industry } \\
\text {-Empowering enterprises }\end{array}$ \\
\hline & $\begin{array}{l}\text { Communicating } \\
\text { brand identities to } \\
\text { segmented targets }\end{array}$ & $\begin{array}{l}\text {-Exploiting export market } \\
\text {-Delivering Korea and product images } \\
\text {-Building trade relations }\end{array}$ \\
\hline $\begin{array}{c}\text { ESTI- } \\
\text { II }\end{array}$ & $\begin{array}{l}\text { Identifying and } \\
\text { developing } \\
\text { brand identities }\end{array}$ & $\begin{array}{l}\text {-Improving export supporting system (special accounts, general trading } \\
\text { company) } \\
\text {-Expanding export products and reinforcing international competitiveness } \\
\text { :Diversifying \& qualifying light industry products } \\
\text { :Prioritizing comparable advantage sources (e.g. machinery, electronics, } \\
\text { shipbuilding) in modernizing HCIs } \\
\text { :Strategically selecting iron \&steel, nonferrous metals, and petrochemicals } \\
\text { in optimal level in line with allied industries } \\
\text {-Expanding international competitiveness of enterprises }\end{array}$ \\
\hline
\end{tabular}




\begin{tabular}{|c|c|c|}
\hline & $\begin{array}{l}\text { Communicating } \\
\text { brand identities } \\
\text { to segmented } \\
\text { targets }\end{array}$ & $\begin{array}{l}\text {-Exploiting export market } \\
\text {-Diversifying export markets } \\
\text {-Delivering Korea \& product image } \\
\text {-Building trade relations }\end{array}$ \\
\hline \multirow[t]{2}{*}{$\begin{array}{c}\text { ESTI- } \\
\text { III }\end{array}$} & $\begin{array}{c}\text { Identifying and } \\
\text { developing } \\
\text { brand identities }\end{array}$ & $\begin{array}{l}\text {-Expanding export structure with high value-added products } \\
\text {-Establishing enterprise-led technology innovation system } \\
\text { :Facilitating enterprises' R\&D institutes } \\
\text { :Expanding high-educated researchers, science and technology facilities } \\
\text { :Establishing enterprise-led partnership among industry, university and } \\
\text { research institute } \\
\text {-Reinforcing market-led technology development system } \\
\text { :Reinforcing technology prediction, research planning, marketing and } \\
\text { evaluation system } \\
\text { :Reinforcing collaborative partnerships with technology-advanced } \\
\text { countries } \\
\text {-Expanding national R\&D projects } \\
\text {-Promoting industry restructure, high-tech and knowledge-based industry } \\
\text { :Restructuring and upgrading HCIs } \\
\text {-Localizing machinery, components and industrial materials } \\
\text {-Restructuring enterprises and supporting their international strategy }\end{array}$ \\
\hline & $\begin{array}{l}\text { Communicating } \\
\text { brand identities } \\
\text { to segmented } \\
\text { targets }\end{array}$ & $\begin{array}{l}\text {-Diversifying with segmented markets } \\
\text { :Main surplus-causing market; main deficit-causing market } \\
\text { Developing market; Special market } \\
\text {-Reinforcing overseas marketing infrastructure } \\
\text { :Expanding overseas exhibitions } \\
\text { :Increasing Korea image PR } \\
\text {-Building trade diplomatic relationships with segmented markets }\end{array}$ \\
\hline
\end{tabular}

In creating and developing the FIEK of Ireland (Table 84), FIEK-P over the period of 1987 through 1990 was advanced by deciding to create Dublin's IFSC. The site for the IFSC was planned. Special corporate tax incentives for IFSC companies were created. The Prime Minister and the Government took the initiative in attracting potential investors worldwide, in particular, from US, European and Far Eastern markets, and strengthening the on-going relations with the target markets. A media campaign was adopted for communication. FIEK-P in the 1990s was reinforced to develop Dublin's IFSC project. Taxation benefits for IFSC companies were preserved and even extended. Place development for IFSC-II was reinforced by adopting a holistic approach to strengthening cultural attractions and social integration. International marketing reinforced the IFSC. FIEK promotion during this period was undertaken for intensive promotion with the existing base of overseas enterprises. Computer manufacturers and ICT industries were selected for brand attraction. Brand communication was concentrated on the existing FDI target market. Communication programmes were used to position Ireland as a business location with advantages including Science, Technology and Innovation. Coming to FIEKP (III) in 1999, the IFSC was highlighted for its vital role in repositioning Ireland as a 
competitive international financial services location. Education linkage programmes were introduced. A government fund for an education facility was allocated. Special tax benefits were kept. A marketing plan was operated by sectoral specialists. To create more knowledge-based industries, FIEK-P since 1999 has been focused on positioning Ireland as a World centre of research excellence. The National Foundation for Excellence in Scientific Research (especially ICT and Biotechnology) has been established. The links between business, universities and other research centres strengthened the Irish $\mathrm{R} \& \mathrm{D}$ competency for market entry. Awareness campaigns have been continued and expanded.

Table 84 Operating Ireland-brand strategies (O-IBS)

\begin{tabular}{|c|c|c|}
\hline \multirow[b]{2}{*}{ FEIK-I } & $\begin{array}{l}\text { Identifying } \\
\text { and developing } \\
\text { brand identities }\end{array}$ & $\begin{array}{l}\text {-Deciding to create Dublin's IFSC } \\
\text { :Selecting the Custom House Docks Area of Dublin's City Centre } \\
\text { :Establishing the Customs House Docks Development Authority (CHDDA) } \\
\text { :Providing special corporate tax incentives for IFSC companies }\end{array}$ \\
\hline & $\begin{array}{l}\text { Communicating } \\
\text { brand identities to } \\
\text { segmented } \\
\text { targets }\end{array}$ & $\begin{array}{l}\text {-Marketing IFSC to the international financial services sector investors } \\
\text {-Customizing and segmenting the target markets for IFSC project } \\
\text { :Attracting overseas investment from US, Europe and Far East } \\
\text { :Strengthening the on-going relations with the target markets, especially } \\
\text { Japan } \\
\text { :Communicating by media campaign }\end{array}$ \\
\hline \multirow[t]{2}{*}{$\begin{array}{c}\text { FIEK- } \\
\text { II }\end{array}$} & $\begin{array}{l}\text { Identifying } \\
\text { and developing } \\
\text { brand identities }\end{array}$ & $\begin{array}{l}\text {-Developing Dublin's IFSC } \\
\text { :Maintaining and extending taxation benefit } \\
\text { :Reinforcing place development for IFSC-II } \\
\text { :Restructuring IFSC Committee } \\
\text {-Undertaking intensive promotion with the existing base of overseas } \\
\text { enterprises } \\
\text {-Selecting from a wide range of segments within information and } \\
\text { communication technology (ICT) industries } \\
\text {-Regional Development Division within IDA Ireland established } \\
\text { :Providing a local service to industry and communities in the Irish regions } \\
\text { :Offering an attractive financial incentive package in favour of regional } \\
\text { Locations }\end{array}$ \\
\hline & $\begin{array}{l}\text { Communicating } \\
\text { brand identities to } \\
\text { segmented } \\
\text { targets }\end{array}$ & $\begin{array}{l}\text {-Reinforcing international marketing for IFSC by IDA Ireland } \\
\text {-Reinforcing FDI promotion to the US market, especially attracting } \\
\text { enterprises based on knowledge intensive and high-value added products } \\
\text {-Maintaining European countries and Japan primarily } \\
\text {-Delivering Ireland and product images } \\
\text { :EMU Business Awareness Campaign } \\
\text { :Science, Technology and Innovation Awareness Programme }\end{array}$ \\
\hline $\begin{array}{c}\text { FIEK- } \\
\text { III }\end{array}$ & $\begin{array}{l}\text { Identifying } \\
\text { and developing } \\
\text { brand identities }\end{array}$ & $\begin{array}{l}\text {-Developing Dublin's IFSC } \\
\text { :Providing continuity to policy-making for the IFS sector } \\
\text { :Enhancing cultural and leisure amenity } \\
\text { :Commissioning a feasibility study for training facility with links to } \\
\text { IFSC companies } \\
\text { :Initiating education linkage programmes and allocating finance } \\
\text { :Applying } 12.5 \% \text { corporation tax regime } \\
\text { :Operating marketing plan by sectoral specialists } \\
\text {-Positioning Ireland as a World centre of research excellence }\end{array}$ \\
\hline
\end{tabular}




\begin{tabular}{|c|c|l|}
\hline \multirow{4}{*}{ (Con't) } & Communicating & -Continuing awareness campaigns \\
& -Extending into a national campaign using both print and national radio \\
& brand identities to & -Stands at exhibitions and conferences \\
& segmented & -Presentations at meetings and seminars \\
& targets & -Handling many queries on the campaign's helpline for business \\
& & -The National Skills Awareness Campaign \\
& & -The National Innovation Conference \\
\hline
\end{tabular}

To develop brand attractions, Korea and Ireland have selected different brand attributes and developed them as their brand identities with supportive measures that fit their target markets. In operating promotion strategies through the periods, Korea has maintained the government's policy of supporting export enterprises and industrial development based on science and technology development. Ireland has continued to provide policy measures for enterprise and industry promotion based on attracting FDI and building knowledge capabilities. Brand communications in both nations have been delivered by different techniques for their own purposes in their respective communication programmes. Even though, Export and FDI markets were focused on US, European, and Japanese markets. Those markets have been maintained or expanded. Korea and Ireland have delivered their nation and product images in these markets, and built their relationships with segmented markets.

Stakeholdership between branding actors in two countries are different. In the ESTI promotions of Korea, the Government (in particular, the Ministry of Commerce and Industry) has developed policies for ESTI-promotions. KOTRA in 1962 was organized for export promotion. Throughout the periods of ESTI-P, KOTRA exploited export markets, delivered Korea and export product images, and, collaborating with Korean embassies, committed to building trade relationships in markets. Over the ESTI-promotions, however, KOTRA mainly established and expanded its own overseas offices rather than networked with other public or private institutions in developing brand attraction and communication for ESTI-promotions. Meanwhile, Ireland during FIEK-P (I) involved the IDA for FDI promotion and CHDDA for the Dublin development. As a result of Prime Ministerial and governmental initiatives, Dublin's IFSC was created. Coming to FIEK-P (II), the Government established Forfás, IDA Ireland and Enterprise Ireland. Since 1999, FIEK-P has, moreover, been speeded up by establishing the Science Foundation Ireland (SFI). Particularly focusing on positioning Ireland as a World centre of research excellence, three agencies (SFI, Enterprise Ireland and IDA Ireland) have collaborated in order to develop new business niches in which Ireland can be a leader, to strengthen the partnerships between business, universities and other research centres, and to attract FDI enterprises. 


\subsubsection{SUSTENANCE OF COMPETITIVENESS OF NATIONS}

With the sustainable competitiveness of Korea and Ireland (Table 85), both countries have achieved economic growth in terms of GDP or GNP and employment improvement.

Table 85 Sustenance of competitiveness of Korea and Ireland

\begin{tabular}{|c|c|c|c|}
\hline Category & Sub-categories & Korea & Ireland \\
\hline \multirow{2}{*}{$\begin{array}{l}\text { National } \\
\text { Development } \\
\text { Goal }\end{array}$} & $\begin{array}{l}\text { Economic \& } \\
\quad \text { Social } \\
\text { Development }\end{array}$ & $\begin{array}{l}\text {-Macroeconomic outcomes } \\
\text { such as economic growth and } \\
\text { employment improvement }\end{array}$ & $\begin{array}{l}\text {-Substantial growth amount not } \\
\text { only in economic performance but } \\
\text { also in social development related } \\
\text { to employment }\end{array}$ \\
\hline & $\begin{array}{l}\text { Human } \\
\text { Development } \\
\text { Value }\end{array}$ & $\begin{array}{l}\text {-Improved standard of living } \\
\text { for Korean people } \\
\text { :Growth in sustainable human } \\
\text { development level }\end{array}$ & $\begin{array}{l}\text {-The best place with 'quality of } \\
\text { life'(Economist, 2004) } \\
\text { :Increasingly sustaining human } \\
\text { development value }\end{array}$ \\
\hline $\begin{array}{c}\text { Project- } \\
\text { based } \\
\text { Goal } \\
\text { Achievement }\end{array}$ & $\begin{array}{l}\text { Export and FDI } \\
\text { Competitiveness }\end{array}$ & $\begin{array}{l}\text {-Export amount growth more } \\
\text { than eight thousand-fold } \\
\text { outpacing national economic } \\
\text { growth rate } \\
\text {-Export products are in leading } \\
\text { positions, particularly } \\
\text { becoming the first largest } \\
\text { shipbuilding nation in the } \\
\text { world, the } 3^{\text {rd }} \text { largest } \\
\text { manufacturer of DRAM chips, } \\
\text { and the } 5^{\text {th }} \text { largest producer } \\
\text { and exporter of automobiles } \\
\text { and steel }\end{array}$ & $\begin{array}{l}\text {-Enterprise competitiveness } \\
\text { :FDI competitiveness in } \\
\text { productivity level and the inward } \\
\text { stock level of FDI }\end{array}$ \\
\hline \multirow{2}{*}{$\begin{array}{c}\text { Nation } \\
\text { Brand Equity }\end{array}$} & $\begin{array}{c}\text { Product } \\
\text { Attribute-based } \\
\text { Equity }\end{array}$ & $\begin{array}{l}\text {-Accomplishing competitive } \\
\text { position based on attractive } \\
\text { products, i.e. HCIs and high- } \\
\text { tech industries, in primary } \\
\text { target markets } \\
\text { :Thirteen products founded on } \\
\text { HCIs and high-tech industries } \\
\text { are positioned as brand } \\
\text { attractions in primary markets }\end{array}$ & $\begin{array}{l}\text {-IFSC as brand differentiator that } \\
\text { repositions Ireland as } \\
\text { International Financial Services } \\
\text { hub } \\
\text {-Knowledge-based products } \\
\text { (chemicals, office machinery and } \\
\text { computer services) are positioned } \\
\text { as brand attraction in primary } \\
\text { target markets }\end{array}$ \\
\hline & $\begin{array}{l}\text { Nation Brand } \\
\text { Perception }\end{array}$ & $\begin{array}{l}\text {-Perceived as advanced country } \\
\text { with high quality-based } \\
\text { products and improved brand } \\
\text { knowledge } \\
\text { :More than } 60 \text { per cent of } \\
\text { foreign audiences recognize } \\
\text { Korea, and most of them } \\
\text { express positive Korea image }\end{array}$ & $\begin{array}{l}\text {-Ireland's competitive advantage } \\
\text { with Irish unique workforce (the } \\
\text { youngest population in Europe } \\
\text { with over } 36 \% \text { under the age of } \\
25 \text { years) and Irish mind (i.e. } \\
\text { flexibility and agility of Irish } \\
\text { people) }\end{array}$ \\
\hline
\end{tabular}


In particular, Korea and Ireland have created the momentum along with envisaging national visions of attaining self-supportive economic and social development systems. Over the decades, Korea has been setting nation-brand goals based on the ESTI that have targeted 'Export-led Korea' for building 'HCIs and 'Science and Technology-advanced Industrialized Korea.' With its ESTI-brand goals, Korea has achieved export competitiveness, which has resulted in the repositioning of Korea as a competitive nation. Since 1987, Ireland has put the emphasis on the brand-goals of creating the IFSC in Dublin and building enterprise competitiveness. Throughout the periods of FIEK-branding, the IFSC-brand became highlighted as the brand differentiator representing Ireland and a focal point of Ireland's economic hub. In terms of its successful productivity growth and inflow levels of foreign-owned enterprises, Ireland has built a reputation for its FDI competitiveness.

Korea and Ireland have distinguished themselves by their branding goal-based accomplishments, i.e. export competitiveness in Korea and FDI competitiveness in Ireland. However, their respective branding positions have characterized to achieve a common result based on their own brand identities. Korea has accomplished a competitive position based on attractive products in HCIs and high-tech industries. Ireland has established competitive identities based on knowledge-based products in ICT. Competitive identities of both countries have been positioned along with their primary target markets. In brand perception, Korea was catagorized as an advanced country and associated with high quality-based product images. Ireland has established a reputation of being associated with the unique Irish competency based on flexibility and agility. With successful repositioning as competitive nations through brand attractiveness, both Korea and Ireland have improved the standard of living for their peoples, and increasingly sustained their human development values.

\subsection{DISCUSSION}

The 'Nation-Branding Mechanism Model (NB-MM)' is a process model that explains branding mechanisms that contextually take place within a nation-brand system and that influence the sustainable competitiveness of nations. Based upon the data collected in Korea's and Ireland's branding, we have analysed contextual phases in the NB-MM, comprising the phases of creating a nation-brand vision (C-NBV), setting a nation-brand goal (S-NBG), developing a nation-brand strategy (D-NBS), operating a nation-brand strategy (O-NBS) and achieving the sustainable competitiveness of a nation. Each phase of the nation-brand building process has distinguished some similar or different branding mechanisms based on branding behaviours (i.e. actors and activities).

In the first phase of 'Creating a nation-brand vision (C-NBV)', Korea and Ireland have both created nation brand visions that have been aligned with national visions. Their national visions and brand visions were established following on analysis of national 
economic and social development status, sources of advantage and the market environment. Similarily, nation brand visions of both nations are characterized as informed, competitive and innovative visions. While, the Korea-Brand Vision was created by a 'top-down' approach, the Ireland-Brand Vision was managed by a 'bottom-up' approach. In the case of a 'top-down' approach to branding Korea, the nation's leaders and governments have proactively initiated the creation of national visions and brand visions. With its bottom-up approach to branding, Ireland has provided a shared vision by the Government and social system and flexibility that reflects policy recommendations from both public and private bodies. In general, it is debated that brand development is more likely to succeed by being managed bottom-up rather than top-down. However, both nations relied on their own development paths, and nation brand visions have been created by nation-specific approaches, i.e. a top-down or a bottom-up approach. In line with that, both nations have applied their own mechanisms to creating their nation brand visions - i.e. to develop the ESTI-brand system and the FIEK-brand system - throughout the branding periods. What is the most essential in creating a nation brand vision is whether the brand vision is envisaged as 'the desired future' for the people and follows the principle consistently.

Nation brand goals (NBG), in branding of Korea and Ireland, have been established by reflecting nation brand visions and analyzing both the strengths and weaknesses in branding resources and opportunities in the branding environment. In developing its ESTIbrand goal, Korea aimed to improve the quality of its export products by developing industry, science and technology qualitatively. To develop the FIEK-brand, Ireland established its brand goals for promoting FDI, knowledge-based enterprise and industry developments. In line with nation brand goals, Korea targeted to exploit export markets, to attain a certain amount of export volumes and to improve country-of-origin effects. Ireland focused on developing a more qualified place environment for living and business, and targeting sustainable employment and productivity. While Korea's ESTI-brand goals were established in a more systematic way from the ESTI-I throughout to ESTI-III, Ireland's FIEK-brand goals were emphasized with more FDI and industrial developments during the FIEK-I and then integrated into enterprise and knowledge development throughout the FIEK-II and III. To establish Korea's ESTI-brand goals, the government bodies were mainly involved in setting the brand goals. The Economic Planning Board played a major role throughout the periods, in particular by coordinating the relevant ministries and allocating the budgets. However, Ireland's brand goals were built through concerted efforts by the Government and its social partners. In particular, Forfás was involved in envisaging the FIEK-brand goals.

Nation brand strategy (NBS) needs to be closely linked to a nation's brand goal and its national strategy for national development. It is about the intended direction of a nationbrand positioning. In developing the NBS, therefore, it is important to define how the nation brand is developed through restructuring national resources and external markets in 
a balanced manner. The nation brand strategy, in branding of Korea, has been embodied in the Five-Year Plans amounting to a national development strategy and, along with FYPs, been concretized by a promotion strategy for developing ESTI-brand system, i.e. Export, Science \& Technology and Industry development. Since 1987 Ireland has developed the PNR, PESP, PCW and P2000 Programmes amounting to a national development strategy. Aligned with these, the Ireland-brand strategy has been focused on developing the FIEKbrand system, i.e. FDI, Industry, Enterprise and Knowledge developments. Korea's ESTIbrand strategies concretized how to restructure national resources (i.e. human resources and export industries) and export markets for competitive advantage and how to position brand attractions (i.e. Science \& Technology-led HCIs and high value-added industries) to export markets. Ireland's FIEK-brand strategy emphasized how to restructure national resources (i.e. human resources and enterprise environment) and FDI markets for competitive advantage and how to position Ireland's competitive identities (i.e. IFSC, Innovative enterprise environment, Knowledge-based enterprise and industry) in FDI markets. In developing ESTI and FIEK brand strategies, the respective governments have shown leadership. Compared to developing the Korean ESTI-brand strategies, Ireland's FIEKbrand strategies have been consistently developed through collaboration with private and public bodies.

To operate a nation-brand strategy (O-NBS), there is a need for a series of activities for creating and developing brand attractions and communicating these. Upholding the consistency of government policy measures plays a significant role in the activities. Collaboration and coordination between branding actors (i.e. Stakeholdership) are mainly considered to be the nation brand's capabilities. The Korean ESTI-brand strategy has worked by focusing on identifying and developing suitable export products. Light industry, science and technology-based HCIs and high-tech industries were created and managed as brand attractions. Ireland's FIEK-brand strategy was implemented by deciding to create Dublin's IFSC, which has been kept throughout the periods. With IFSC-brand, the brand strategy was undertaken by selecting competitive industry products, i.e. knowledge-based industries (e.g. ICT or biotechnology). ESTI and FIEK brand strategies have been distinguished by target market-specific approach, i.e. the Export market and the FDI market. Brand attractiveness, in the process of branding of both nations, have been developed along with brand benefits, i.e. supportive policy measures such as incentives or subsidies to foreign enterprises for FDI or to indigeneous enterprises for exporting. Brand benefits promoted ESTI-brand and FIEK-brand developments, which strengthened brand attractions and brand communication. Even though each nation has taken a different approach to its target markets (i.e. Export and FDI) and communication tools, they have both highlighted branding mechanisms in terms of exploiting strategic markets, delivering country images and building relationships with their target markets. Stakeholdership between the Government agencies and its social partners have been prominently emphasized in operating the nation brand strategies. In implementing Korea's ESTI-brand 
strategy, KOTRA played a major role with its overseas network offices. However, throughout the ESTI-branding periods, KOTRA lacked collaboration with other public and private institutions, such as design or culture-relational organizations, to develop brand attractiveness and brand communication. Meanwhile, in Ireland's FIEK-brand operations, the IDA for FDI promotion during FIEK-P (I) involved Dublin's re-development. In particular, to reposition Ireland as a World centre of research excellence, three agencies (SFI, Enterprise Ireland and IDA Ireland) collaborated in creating knowledge-based business niches for brand attractiveness, attracting and retaining FDI enterprises.

Korea and Ireland have developed the ESTI-brand and the FIEK-brand over several decades. During the periods of ESTI-branding and FIEK-branding, both nations attained to a large extent their national development goals. In terms of economic and social development, Ireland and Korea experienced enormous economic growth and employment effects. Human development values for both nations have been improved and consistently sustained. In line with its project-based goal, Korea has focused on ESTI-brand development, and has achieved export competitiveness in export volume, industrial structure and competitive positions in its markets. Ireland, through FIEK-brand development, has achieved FDI competitiveness. Foreign enterprises have increasingly decided to invest in Ireland. In particular, knowledge-based enterprises reinvested for their business growth in Ireland. National resources and market environments have been considered as the main entities in branding activities. To take a competitive position in a target market, nations have restructured national resources and market environments by exploiting them, and achieved nation brand equity. With the process of developing the ESTI-brand and the FIEK-brand, Korea and Ireland have improved country images in the global market and accomplished positive reputations. To achieve customer-based brand equity, Korea has attained a competitive position based on attractive products, i.e. HCIs and high-tech industries, in its primary target markets. The IFSC has been the brand differentiator in the FDI market, creating an Irish International Financial Services hub. Also, knowledge-based products have been positioned as brand attractions in primary target markets to attract FDI. The Korean ESTI-brand and the Irish FEIK-brand have been developed by branding mechanisms that include branding actors and activities during each phase of the 'Nation-Branding Mechanism Model,' and sustained through the multiple nation-branding episodes over long-term periods. 


\section{CHAPTER 8 CONCLUSIONS AND RECOMMENDATIONS}

\subsection{CONCLUSIONS}

\subsubsection{A PROCESS MODEL FOR NATION BRANDING}

Aiming to assess the role of nation branding and create a strategic management tool on nation branding for the sustainable competitiveness of nations, the study has formulated research questions: how does nation branding contribute to the sustainable competitiveness of nations? And how can we design a comprehensive framework for nation branding that facilitates effectively the sustainable competitiveness of a nation? This research has proposed the 'Nation-Branding Mechanism Model (NB-MM)' as an integrated model for a strategic branding approach. Through the empirical findings, we found that the 'NB-MM' is an effective way of designing a strategic nation-branding approach. This section provides the elements for how the NB-MM should be revised.

Testing the model by executing the branding cases of Korea and Ireland, we highlight the important empirical evidence for nation branding as follows. Firstly, nation branding is the process that must be aligned with country management and influences the sustainable competitiveness of nations. We have assumed that a nation brand must drive national strategy at the heart of country management and, in order to achieve this, nation branding must be a strategic pillar guiding how the competitiveness of a nation should be sustained. Extending the concept of national competitiveness to the branding perspective, our study has explored the effects of the nation-branding process in terms of the national development goal, the project-based goal and nation brand equity. Based on these criteria, the nation-branding processes in both Ireland and Korea have been found to be closely aligned with their national strategies, and have been the drivers of achieving the economic growths, employment effects, human development values, export and FDI competitiveness, positive reputation and competitive identities.

Secondly, to sustain the competitiveness of nations, nation branding is the process that needs a system approach to building the nation brand. As in the relevant literature, our study has emphasized the need to develop a nation brand with national identities based on the reality of a nation, and to manage the nation brand to be attractive and communicable in the market. Our model has highlighted two aspects, i.e. resources and environment, as the sources that are inextricably linked to the nation-branding process. Korea and Ireland have each developed a nation-specific brand system, namely ESTI and FIEK. In developing the brand systems, both nations have shown that their branding processes have analyzed the strength and weakness of their branding resources (i.e. industry, human capital and enterprise environment), captured opportunities towards their strategic markets (i.e. export and FDI markets), restructured branding resources to be more attractive, and exploited 
those markets by using competitive identities. Aligning with national strategy, the nationbranding process has to restructure a nation's branding resources, to exploit target markets, and to create the brand identities and images in a systematic and consistent way.

Thirdly, nation branding is a mechanism-based process that is structured with a set of activities carried out by branding actors. That is, the nation-branding process encompasses multiple episodes of branding mechanisms to build a nation-brand system. In the 'NationBranding Mechanism Model (NB-MM)', we have claimed that the nation-branding process comprises a sequence of phases of creating a nation-brand vision (C-NBV), setting a nation-brand goal (S-NBG), developing a nation-brand strategy (D-NBS) and operating a nation-brand strategy (O-NBS). The ESTI and FIEK brand systems of Korea and Ireland respectively have been developed through sequential branding phases from creating the brand vision through to operating the brand strategy. The phases include branding mechanisms encompassing branding actors (i.e. national leaders, governments, promotion agencies and social systems) and their activities to create the brand vision, to set the brand goal, to develop the brand strategy and to operate the brand strategy. Each nation takes a different path to national development and employs nation-specific mechanisms. Korea and Ireland have developed nation-specific brand systems based on their own branding mechanisms. Within their specific contingent conditions, both nations have shown the relevant contextual patterns in the process based on the 'Nation-Branding Mechanism Model (NB-MM).'

Finally, nation branding is found to be an ongoing and iterative process of developing the nation-brand system, being triggered by market behaviour such as built-in stereotype. It influences the sustainable competitiveness of a nation. Our research has emphasized that a longitudinal approach based on temporal dimensions is an appropriate approach to understanding how the nation brand has evolved along with a nation's development path and how the nation-brand system has been developed throughout the brand development process. The ESTI and FIEK brand systems have been developed with the critical encounters as turning points for the brand development. Within the encounter, the branding mechanisms have consisted of the episodes of the nation-brand systems. Applying an iterative branding process, Korea and Ireland have over decades established their nationbrand systems.

Based on the empirical findings, the 'Nation-Branding Mechanism Model (NB-MM)' can be extended as depicted in Fig. 28. 
Fig. 28 The Nation-Branding Mechanism Model

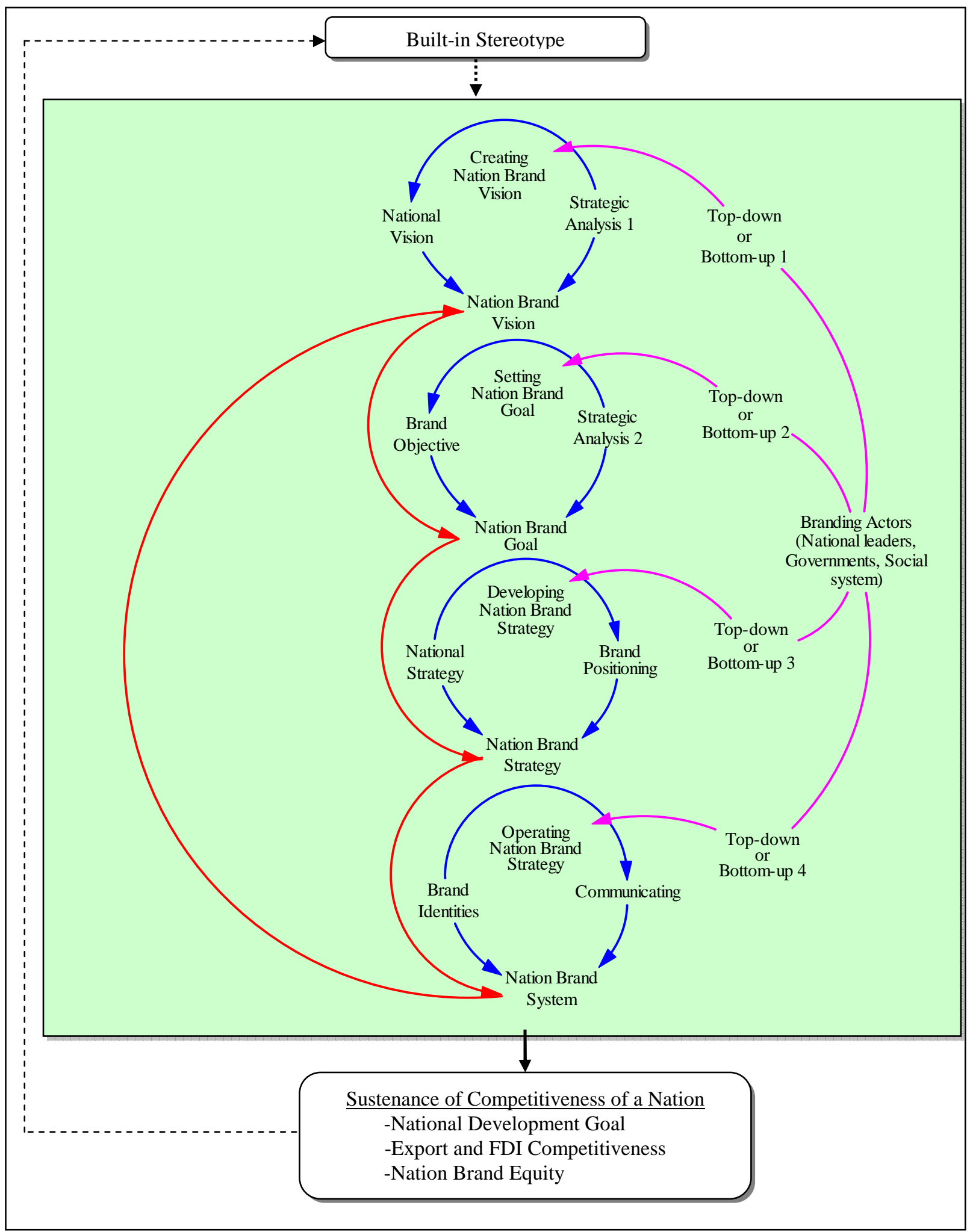




\subsubsection{CONTRIBUTION OF THIS RESEARCH}

Nation branding has become an emerging discipline that combines the principles of both marketing and international relations. Also, it refers to the domain extending the unitof-analysis in branding theory and practice into a nation level as an umbrella concept of national brands. Considering nation branding to be a powerful means to achieve development growth, competitive advantage and brand equity for a nation, this research has aimed to define the role of nation branding and create a strategic management tool on nation branding for the sustainable competitiveness of nations. In particular, reflecting the challenges of the nation-branding study, we have highlighted the substantial tasks involved in building a systematic model to sustain the nation-brand system and taking a brand management approach to the effectiveness of the outcomes of nation branding. In many cases developing the nation brand, researchers have pointed out that nation branding, whether in theory building or in practice, needs to take a planned approach to achieving effective nation branding. Furthermore, this research has presented the criteria to building a nation-branding model, emphasizing the notion of nation-brand alignment with country management to sustain a nation's competitiveness, and developed a 'Nation-branding Mechanism Model' as a mechanism-based value-creating process model. With empirical testing, our research has referred the 'Nation-branding Mechanism Model' as an effective model for designing a nation branding approach and for explaining performance in nation branding. Through the model's development, this research contributes to the building of a body of knowledge in the study of nation-branding as described below.

\section{NATION BRANDING AS A STRATEGIC MANAGEMENT}

The 'Nation-Branding Mechanism Model' contributes to building the nation-branding theory from the brand management perspective. As a source of sustainable competitiveness, nation branding has been coupled with the notion of brand management. Reviewing the literature, we have emphasized that the concept of nation branding has evolved by combining country-of-origin, place development, and public diplomacy, and that nation branding needs an umbrella branding and a holistic brand management approach to achieving the internal and the external nation-brand effects (i.e. sustainable competitiveness). In particular, reflecting the importance of a nation-brand alignment with country management, we have identified key concepts of nation branding in terms of aligning the national strategy and its direction, building a nation brand strategy, building the nation brand identity and image, and managing nation brand behaviour. To incorporate these concepts into creating and sustaining a nation-brand system, our research has highlighted the management role of nation branding. By applying the notions of competitiveness and sustainability in the era of globalization, we have focused on the extent to which the variables in nation branding contribute to the achievement of outcomes 
of nation branding. In explaining the relationship between nation branding and sustainable competitiveness, we have developed a model that addresses the dynamics integrating a sequence of input, process and outcome. The 'Nation-Branding Mechanism Model' highlights how the integrated management of nation branding drives the sustainable competitiveness of nations.

More particularly, our study first provides the process model that is suitable for explaining the causes that influence sustainable competitiveness of nations. We need to understand branding as a management process that goes into generating the outcomes (Pickton, 2008). Based on the notion of organizational theory discoursing a dynamic process in achieving sustainable competitiveness, it is important to build a process model that can explain how an organization sustains its competitiveness by aligning that organization's vision, goal and strategy. However, researchers have pointed out that despite the growing body of literature dealing with nation branding, there is limited information available about processes and outcomes. In addition, the underlying assumptions behind contemporary branding models are largely incompatible with the notion of nation branding as a source of sustainable competitiveness. Nation branding is all about managing a nation brand and ultimately achieving brand equity, competitive advantage and sustainable development of a nation as components of the effectiveness of nation branding. To help manage the nation brand effectively, our study has challenged to develop a process model that is suitable to align the nation brand with country management. Our 'Nation-Branding Mechanism Model' provides that, to manage the nation brand successfully, it is important to align the nation brand to the nation's strategy, in particular, the economic, political, social and cultural development strategy. Moreover, the NB-MM explains the strategic process of how a nation's brand vision, brand goal and brand strategy are aligned. The process-based approach is central to modern management theories (Lorino \& Tarondeau, 2002). Our findings through the NB-MM sum up managerial significance of nation branding as a central pillar in country management, which contributes to both branding and management theories. Concretely,

- This research provides a strategic management process model that is suitable for aligning the nation brand with country management and explaining the management role of nation branding that influences the sustainable competitiveness of the nation.

Secondly, we highlight the adoption of a mechanism-based process model to explain how nations develop a nation-specific brand system. Researchers have found that countries have developed their own development path or mechanisms, and that the mechanisms have emerged from behaviours by interactions between actors and activities. In particular, a mechanism-based organizational theory is based on the concept that in achieving a sustainable competitiveness, a successful organization distinguishes the mechanism of restructuring and creating resources and environment through the organization's actors. Brand management is about working on the context of action (Arvidsson, 2006:190). In 
marketing a place, place is effectively managed by means of the strategic planning process based on mechanisms. While marketing is a planned exercise and focuses on market mechanisms, the aim of nation branding is to pursue a substantial and holistic sustainability by turning 'the quality of context' into 'competitive advantage' in international business (Pant, 2005). Through the 'Nation-Branding Mechanism Model', this research explains how nations develop the nation-brand systems through applying the branding mechanisms, i.e. restructuring branding resources and environments, creating competitive identities and simultaneously communicating with strategic markets. Our research explains the role of nation branding that aims to achieve sustainable development, competitive advantage, national product equity and reputational equity. Therefore,

- Our study contributes to the building of a mechanism-based nation branding approach that affects effectively the sustainable competitiveness of a nation.

Thirdly, the 'Nation-Branding Mechanism Model' addresses what the reality-based brand management model is and how it is suited to explaining that nations create national identity and image on the basis of a nation's reality. Building a country's image and identity has been inextricably linked with managing the nation brand. Jaffe and Nebenzahl (2006:15) have insisted that country image is considered a dynamic phenomenon and is subject to intentional managerial influence, which should be strategically determined and controlled by branding. Meanwhile, Hankinson (2004:111) has asserted that the role of brand management is to define and manage a brand identity as a means of achieving competitive advantage. Rainisto (2003:73) has contended that place identity is a result of planned activities. Researchers have advocated that the nation's image is inevitably linked with the national identity, and that for effective nation branding, national image and identity must be based on the reality of the country. Many researchers on country-of-origin, place development, national identity, country image and public diplomacy have already defined reality-based associations. Managing national image and identity is about managing the reality of a country that has been driven both locally and globally. Exploring brand management patterns in branding and strategic management theory, Louro and Cunha (2001) have pointed out that the development of the resource-based view of the organization and brand equity research, coupled with marked transformations in market dynamics and structures, has led to a reconfiguration of managerial and academic views on the role and importance of brands. Moreover, they have argued that the increasing recognition of the significance of brands as sources of sustained competitive advantage increases the importance of supporting and refining the models underlying organizations' brand strategies. The 'Nation-Branding Mechanism Model' is a model that explains how nations create, manage and sustain national identity and image by managing the reality of a nation through a strategic nation branding approach. Therefore,

- This study contributes to providing the reality-based brand management approach to building and managing national identity and image. 
Finally, this research contributes to a systematic and holistic management model that explains how the nation-brand system is created by the mechanism reflecting the dynamic phenomenon of a nation's reality. Reality is changing over time. Therefore, for effective nation branding, it must correspond to internal and external reality changes in a systematic way and uphold continuity in building identity and image in a holistic way. Based on a corporate-branding perspective, researchers have articulated the 'systems' approach (Shocker et al., 1994) and presented systematic or integrated models for sustainable internal and external benefits to organizations, highlighting a behavioural and holistic approach (Burmann \& Zeplin, 2005; LePla \& Parker, 2002; De Chernatony, 2001). In branding a place, researchers (Skinner \& Kubacki, 2007; Freire, 2005; Pant, 2005) have pointed out the importance of a wide range of factors in multidimensional models and of building the brand system of place. However, existing models have rarely defined what a nation-brand system is and how nations have created and developed such systems. Moreover, they have asserted the importance of considering branding actors in the models. What is an important notion is that branding actors are typically involved in development and execution in various stages, and that their composition and actions vary depending on the country output involved (Papadopoulos \& Heslop, 2002:310-311). However, there are few studies that have conceptualized the branding mechanism based on the behavioral approach - encompassing both branding actors and activities in the phase of the brandbuilding process. Although much progress has been made in branding research, as Keller (2001) has pointed out, one of the most important research priorities in branding theory is to develop more comprehensive and realistic models which are useful across a broad range of decision-making settings. The developed 'Nation-Branding Mechanism Model' offers a refined and integrated model that comprehends concepts related to nation brand building across different academic disciplines. In particular, the NB-MM explains what a nationbrand system is and how such a system is contextually and holistically created by the branding mechanism that reflects the dynamic phenomenon of a nation's reality change affecting the sustainable competitiveness of a nation over time. Therefore,

- This research contributes to the design of a strategic nation-brand management model that creates systematically the nation-brand system and sustains effectively the nation's competitiveness. 


\subsection{RECOMMENDATIONS}

Nation branding is an emerging and growing research discipline. Investigating the role of nation branding with respect to sustainable competitiveness of nations, we have defined how nations have sustained their competitiveness through the nation-brand building process. In particular, this research has contributed to the development of a nation-branding model (the Nation-Branding Mechanism Model) and, based on the model, to the explication of the relevance between nation branding and sustainable competitiveness of nations.

Moreover, through the 'Nation-Branding Mechanism Model', we contribute to building a nation branding theory from the strategic brand management perspective. Reseachers in brand management insist that brand management should involve strategic and holistic decisions in order to reposition a premium brand as a value brand (Wood, 2000). In more concrete terms, Keller (2001:4) claims that branding effects are highly dependent on the context involved, and that brand management challenges us to understand the totality of the possible antecedents and consequences of branding activity and the possible mechanisms involved. Future research needs to extend the current research in terms of the total brand management context. The following recommendations are made.

Total brand management, reflecting what Keller (2001) stated, is to consider the dynamics of integrating input-process-output of nation branding. Our research has been limited to a focus on the process and output of nation branding, without defining input measures such as stereotype. Stereotype characterizes a contradictory aspect to be compatible with nation branding process. As Anholt (2007a:27) has argued, on the one hand, stereotype (that is the reputation of country, whether good or bad) seldom really reflects the current reality of the place because of time lag between image and reality. That is to say, a place may be changing quite quickly, but its image can lag behind by years or even decades (Ibid). In the notions of country-of-origin and country image, on the other hand, stereotype is considered as a mechanism that people in target markets use to simplify the world and develop over their lifetimes. Nation branding is the process of transforming stakeholders' stereotypes into the sustainable competitiveness of the country. Therefore, we need to consider this built-in stereotype in nation branding model. Our research focused on how these nations have successfully performed in terms of export and FDI brand systems, and on the longitudinal scope in comparing the branding cases of Korea and Ireland, to explain the brand management process. Korea has been positioned as one of the Asian tigers. Ireland has been perceived as a Celtic tiger. To compare the brand management of both nations, our research has adopted them as nations positioned in a similar country image category, but has not investigated stereotypes along with its longitudinal scope. Our research suggests that further research should include what kinds of stereotypes have been 
built on in each country and how nations have differently managed nation brand systems within the 'Nation-Branding Mechanism Model.'

In contemporary management science, brand management is about working on the context of action (Arvidsson, 2006). There remains a need to develop more actionable models of brand equity (Keller, 2001). A nation brand is a 'living system', and a nationbrand building process must involve an inclusive brand behaviour to make the nation-brand system live, which enables to build a fully actionable model on sustainable competitiveness which implies nation brand equity. In the process of nation branding, our research has found that a nation-brand system has been developed on a nation-specific development trajectory, and that it has been invigorated by branding mechanisms based on the behaviours of integrating actors with activities. However, our research has focused on finding branding mechanisms through a longitudinal scope, which has limited the findings to defining branding behaviors and mechanisms within an export or FDI branding system. LePla and Parker (2002) have asserted that the integrated brand model is claimed to be holistic, and by developing an integrated brand, organizations may gain sustainable benefits both internally and externally. Our research needs to build a more holistic and systematic model through explaining the integrated brand system of an export and FDI branding within a nation. Therefore, we recommend that further research must stretch into exploring branding behaviours and mechanisms more thoroughly in converging export and FDI branding systems into a single nation-brand system.

Moreover, we highlighted that nation branding has evolved with three domains of country-of-origin, place development and public diplomacy, which have upheld the role of nation branding. A key management role in the nation branding process is to combine these three domains into one concept of nation branding so as to create a nation-brand system and to achieve nation brand effects both internally and externally. In this managerial process the context of nation branding, creativity and relationship notions are imperatives. De Chernatony (2001) has argued that it is necessary at all stages to consider creatively unique ways of building the brand. Creativity must be applied systematically throughout the strategy process from creating a vision for the brand to the design and delivery of branded products and services (Van Gelder, 2005). Anholt (2006a) has asserted that a strong brand strategy is essential to clarifying the process, which imposes demands on the creativity that devises the brand strategy. Creativity is imbedded in the organization (Van Gelder, 2005), and creative organizations break down the barriers both within the organization and with the outside world (Ind \& Watt, 2004). Nations can sustain their competitive advantage and sustainable development through the branding mechanism of creating competitive identities and images. Meanwhile, Hankinson (2004) presented the concept of a brand as a relationship. As a new approach to brand equity, there are the relational aspects of the brand that contribute to brand equity (Jones, 2005). A creative nation brand can be effective through building a trust-based relationship with both internal and external stakeholders, which underpin nation brand effects. In particular, we note that 
research emphasizes the role of governance in building creativity and relationships. Therefore, future study needs to consider creativity-based and relationship-based behaviours with branding governance in terms of exploring branding mechanisms on the sustainable competitiveness of nations.

Strategic brand management aims to build, measure and manage brand equity (Keller, 1998:594). Our model has presented nation brand equity in line with sustainable competitiveness. There are some common approaches to measuring brand equity at a corporate branding level. Jones (2005) states that the most common approach to brand equity is divided into three categories: mental brand equity - the impact of the brand on the consumer's consciousness; behavioural brand equity - consumer's behavioural response to the brand; financial equity - the financial impact of the brand as expressed through return on investment, profit, turnover, price-to-earnings ratio. Abela (2003) categorises brand equity measurement using an additive or inclusive approach. According to these researchers, theory and practice present a series of challenges to traditional approaches to brand equity, and an inclusive approach is preferable to an additive one because they consider a much broader concept of "branding." Our research has focused on FDI and export branding, which has been limited to defining FDI and export competitiveness based on financial equity. Based on the ESTI and FIEK brand systems, we identified productbased and perception-based equities. However, we limited ourselves to defining behavioral brand equity considering both consumers and branding actors. In the total brand management context, further research into nation branding needs to measure all the variables within a nation-brand system and nation brand equity both inclusively and explicitly.

Developing sound theory to guide brand management is increasingly necessary and should be integrative (Shocker et al., 1994). There is a great need for integrative studies to merge the available knowledge across the various individual disciplines (Papadopoulos, 2004:47). Nation branding study needs to interact with the relevant theoretical contexts and to adapt them to building nation branding knowledge. An integrative approach to developing nation-branding theory must be reflected in building effective nation branding models. Particularly reflecting that nation branding comprises multifaceted complex dimensions, we recommend incorporating the concepts of systems and systemic thinking into any future development of our nation branding model. Key insights of systems theory relevant to organizations have been reflected in a theoretical base for strategic management (Sanchez, 2002). Taking a systems theory, nation branding study can extend to exploring a nation-brand system and its effective management.

Research into nation branding has applied methodological approaches to case studies using qualitative techniques and historical analysis. To refine the research model termed the 'Nation-Branding Mechanism Model', this research has adopted a comparative case study providing a qualitative and in-depth approach in explaining performance in nation branding. Korea and Ireland have been focused on explaining how nations have sustained 
competitiveness based on export and FDI branding, which has provided the necessary degree of understanding of the relationship between nation branding and competitiveness. We recommend further research to determine whether our model is applicable to other cases of nation branding and will remain valid. In reflecting systems theory and systemic thinking to understanding a small number of systems (Hall, 2006; Senge et al., 1994), future research needs to adopt the tools that enable a broad array of methodological approaches to generalizing our model, particularly focusing on the umbrella concept of nation branding. 


\section{REFERENCES}

Aaker, D. A. (1989). Managing assets and skills: the key to a sustainable competitive advantage. California Management Review, 31(2):91-106

Aaker, D. A. (1998). Strategic market management. New York: John Wiley \& Sons

Abbott, A. (1988). Transcending general linear reality. Sociological Theory, 6 (Fall): 16986

Abela, A. (2003). Additive versus inclusive approaches to measuring brand equity: practical and ethical implications. Journal of Brand Management, 10:342-52

Abimbola, T. (2006). Market access for developing economies: branding in Africa. Place Branding, 2(2):108-17

Adcock, D. (2000). Marketing strategies for competitive advantage. Chichester: John Wiley \& Sons

Aggarwal, P. (2004). The effects of brand relationship norms on consumer attitudes and behavior. Journal of Consumer Resesrch, 31(June):87-101

Aguirre, X. A. and Renjel, X. S. (2008). Using nation branding to move beyond 'trickledown tourism': The case of Bolivia. In: Dinnie, K. (2008). Nation Branding:concepts, issues, practice. Oxford: Butterworth-Heinemann, p.165-68

Ahmed, Z.U., et al., (2002). Country-of-origin and brand effects on consumers' evaluations of cruise lines. International Marketing Review, 19(3):279-302

Allali, B. (2006). Owner-managers'vision and its role in the internationalization of SMEs: a multiple case study of Moroccan and Canadian SMEs in the Agri-food sector. Revista de Negócios, Blumenau, 11(2):5-23

Amine, L.S. and Chao, M.C.H. (2005). Managing country image to long-term advantage: the case of Taiwan and Acer. Place Branding, 1(2):187-204

Andrews, K. R. (1980). The concept of corporate strategy. Homewood: Dow-Jones Irwin

Anholt, S. (2008). From nation branding to competitive identity-the role of brand management as a component of national policy. In: Dinnie, K. (2008). Nation Branding:concepts, issues, practice. Oxford: Butterworth-Heinemann, p.22-23

Anholt, S. (2007a). Competitive Identity. London: Palgrave Macmillan

Anholt, S. (2007b). Interview with David Gertner, January 2007. In: Gertner, D. (2007). Editorial, 'Place branding:dilemma or reconciliation between political ideology and economic pragmatism?' Place Branding and Public Diplomacy, 3(1):3-7 
Anholt, S. (2007c). http://simonanholt.blogspot.com/2007

Anholt, S. (2006a). Why brand? Some practical considerations for nation branding. Place Branding, 2(2):97-107

Anholt, S. (2006b). Editorial. Place Branding, 2(3):179-82

Anholt, S. (2005a). Brand New Justice (revised edition). Oxford: Butterworth-Heinemann

Anholt, S. (2005b). Some important distinctions in place branding. Place Branding, $1(2): 116-21$

Anholt, S. and Hildreth, J. (2005). Let freedom and cash registers ring: America as a brand. Place Branding, 1(2):164-72

Anholt, S. (2004). Editorial's foreword to the first issue. Place Branding, 1(1):4-11

Anholt, S. (2003). Brand New Justice: The Upside of Global Branding. Oxford: Butterworth-Heinemann

Anholt, S. and Van Gelder, S. (2003). Branding for good? In: Ind, N. eds. (2003). Beyond Branding. London: Kogan Page, p.56-68

Anholt, S. (2002a). Foreword. Journal of Brand Management, 9(4-5):229-39

Anholt, S. (2002b). Nation Branding: a continuing theme. Journal of Brand Management, 10(1):59-60

Anholt, S. (2000). The Nation as Brand. Across the Board, Nov/Dec., 22

Anholt, S. (1998). Nation-brands of the twenty-first century. Journal of Brand Management, 5(6):395-406

Anholt, S. and GMI (2004). Anholt-GMI Nation Brands Index.

<http://www.gfkamerica.com/practice_areas/roper_pam/nbi_index/index.en.html>

Arvidsson, A. (2006). Brand value. Journal of Brand Management, 13(3):188-92

Ashworth, G. J. and Voogd, H. (1994). Marketing and place promotion. In: Gold, J. R. and Ward, S. V. eds. (1994). Place Promotion: the use of publicity and marketing to sell towns and regions. Chichester: John Wiley \& Sons, p.39-52

Audretsch, D. B. (1997). Industrial Policy and International Competitiveness. London: Edward Elgar

Bacharach, S. B. (1989). Organizational theories: some criteria for evaluation. Academy of Management Review, 14(4):496-515 
Bacon, T. R. and Pugh, D. G. (2003). Winning behavior: what the smartest, most successful companies do differently. New York: Amacom

Bagheri, A. and Hjorth, P. (2007). Planning for sustainable development: a paradigm shift towards a process-based approach. Sustainable Development, 15:83-96

Barney, J. B. (1991). Firm resources and sustained competitive advantage. Journal of Management, 17(1):99-120

Barwise, P. (1993). Brand equity: snark or boojum? International Journal of Research in Marketing, 10(March):93-104

Bátora, J. (2005). Public diplomacy in small and medium-sized states: Norway and Canada. Hague: Clingendael

Bauer M.W., Howard, S., Hagenhoff, V., Gasperoni, G. and Rusanen, M. (2005). The BSE and CJD crisis in the press. In: Dora, C. eds. (2005). Health, Hazard and Public Debate:Lessons for risk communication from the BSE/CJD saga. Geneva: WHO, p.125-64

Beauchamp, J. (2001). Vision and the visionning activity of organizational leaders. Montreal: McGill University

Beer, M. (2001). How to develop an organization capable of sustained high performance: embrace the drive for results-capability development Paradox. Organizational Dynamics, 29(4):233-47

Bilkey, W. and Nes, E. (1982). Country of origin effects on product evaluations. Journal of International Business Studies, 13(Spring/Summer):89-99

Blichfeldt, B. S. (2005). Unmanageable place brands? Place Branding, 1(4):388-401

Bond, P. (2005). Debates in local economic development policy and practice. In: Nel, E. and Rogerson, C. eds. (2005). Local economic development in the developing world. New Brunswick: Transaction Publishers, p.57-74

Boltho, A. (1996). The assessment:international competitiveness. Oxford Review of Economic Policy, 12(3):1-16

Borja, J. and Castells, M. (1997). Local and Global: the management of cities in the information Age. London: Earthscan

Bruce, C. (2003). Modeling the environmental collaboration process: a deductive approach. Discussion paper. Calgary: University of Calgary

Bryson, J. and Bromiley, P. (1993). Critical factors affecting the planning and implementation of major projects. Strategic Management Journal, 14(2):319-37 
Buckley, P. J. and Ghauri, P.N. (2004). Globalisation, economic geography and the strategy of multinational enterprises. Journal of International Business Studies, 35(2): 8198

Buckley, P., Pass, C. L. and Prescott, K. (1988). Measures of international competitiveness: a critical survey. Journal of Marketing Management, 4(2):175-200

Burmann, C. and Zeplin, S. (2005). Building brand commitment: a behavioural approach to internal brand management. Journal of Brand Management, 12(4):279-300

Cai, L. A. (2002). Cooperative branding for rural destination. Annals of Tourism Research, 29(3):720-42

Caldwell, N. and Freire, J. R. (2004). The differences between branding a country, a region and a city: applying the brand box model. Journal of Brand Management, 12(1):50-61

Capik, P. (2007). Organising FDI promotion in Central - Eastern European regions. Place Branding and Public Diplomacy, 3(2):152-63

Castells, M. and Susser, I. (2002). The castells reader on Cities and Social Theory. Oxford: Blackwell

Castells, M. (1996). The rise of the Network Society (The information age: economy, society and culture: volume I). Oxford: Blackwell

Chinen, K., Enomoto, C.E. and Costley, D. L. (2000). The country-of-origin effect on Toyotas made in Japan, the USA and Mexico. Journal of Brand Management, 8(2):139-48

Cho, D. S. (2006). Mechanism Management. Seoul: Hans media

Cho, D. S. (2004). 국가브랜드. In: 산업자원부 산업기술기반조성사업 브랜드경영연구, eds. (2004). 국가브랜드와 제휴· $M \& A$ 시의 브랜드관리. Seoul: Industrial Policy Studies, p.38-65

Cho, D. S. (1997). Environment-Creating Mechanism of Companies. Seoul: IBS

Clarke, A. (2002). The Ideal and the real: cultural and personal transformations of archaeological research on Groote Eylandt', Northern Australia. World Archaeology, 34(2):249-64

Clifton, R. (2004). Opinion Pieces 'Where is place branding heading?' Place Branding, 1(1):12-35

Collis, D. J. and Hussey, R. (2003). Business research: a practical guide for undergraduate and postgraduate students. $2^{\text {nd }}$ ed. Basingstoke: Palgrave Macmillan 
Collis, D. J. and Montgomery, C. A. (1995). Competing on resources: strategy in the 1990's. Harvard Business Review; 73(4):118 -28

Cooper, R. and Schindler, P. (2003). Business research methods. $8^{\text {th }}$ ed. Boston: McGrawHill

Damjan, J. (2005). Development of Slovenian brands: oldest are the best. Place Branding, $1(4): 363-72$

Davenport, T. H. (1994). Managing in the new world of processes. Public Productivity \& Management Review, 18(2):133-47

Day, G. S. (1990). Market-driven strategy: processes for creating value. New York: Free Press

Day, G. S. (1994). The capabilities of market-driven organizations. Journal of Marketing, 58(Oct):37-52

Day, G. S. and Nedungadi, P. (1994). Managerial representations of competitive advantage. Journal of Marketing, 58(April): 31-44

Day, G. S. and Wensley, R. (1988). Assessing advantage: a framework for diagnosing competitive superiority. Journal of Marketing, 52(April):1-20

De Bono, E. (2006). Asian brand strategy. In: Roll, M. eds. (2006). Asian Brand Strategy: how Asia builds strong brands. UK: Palgrave Macmillan, p.96-128

De Chernatony, L. (2001). A model for strategically building brands. Journal of Brand Management, 9(1): 32-44

De Chernatony, L., Riley, F. and Harris, F. (1998). Criteria to assess brand success. Journal of Marketing Management, 14(7):765-81

De Gouveia, P.F. and Plumridge, H. (2005). European Infopolitik: developing EU public diplomacy strategy. London: The Foreign Policy Centre

De Vicente, J. (2004). State branding in the 21st century. <http://fletcher.tufts.edu>

Dickson, P. R. (1996). The static and dynamic mechanics of competition: a comment on Hunt and Morgan's comparative advantage theory. Journal of Marketing, 60(4):102-6

Dinnie, K. (2008). Nation Branding: concepts, issues, practice. Oxford: ButterworthHeinemann

Djerejian Report (2003). Changing minds winning peace: a new strategic direction for U.S. Public-Diplomacy in the Arab \& Muslim world.

<http://www.state.gov/documents/organization/24882.pdf> 
Dooley, G. and Bowie, D. (2005). Place brand architecture: strategic management of the brand portfolio. Place branding, 1(4):402-19

Dunning, J. H. (1979). Explaining changes of international production: In defence of eclectic theory. Oxford Bulletin of Economic and Statistics, 41(4):269-96

Dzenovska, D. (2005). Remaking the nation of Latvia: anthropological perspectives on nation branding. Place Branding, 1(2):173-86

Easterby-Smith, M., Thorpe, R. and Lowe, A. (2002). Management research: an introduction. $2^{\text {nd }}$ ed. London: Sage

Economist Intelligence Unit (2005). The Economist Intelligence Unit's quality-of-life index. The World In 2005

Erickson, G. M., Johansson, J. K. and Chao, P. (1984). Image variables in multi-attribute product evaluations: country-of-origin effects. Journal of Consumer Research, 11(September):694-99

Eisenhardt, K. M. (1989). Building theories from case study research. The Academy of Management Review, 14(4):532-50

Endziņa, I. and Luñeva, L. (2004). Development of a national branding strategy: the case of Latvia. Place Branding, 1(1):94-105

Etzel, M. J. and Walker, B. J. (1974). Advertising strategy for foreign products. Journal of Advertising Research, 14(3):41-44

Fan, Y. (2007). Soft Power: power of attraction or confusion? Middlesex: Brunel University

Fan, Y. (2006). Branding the nation: what is being branded? Journal of Vacation Marketing, 12(1):5-14

Farquhar, P. H. (2005). Brand alignment across organisational boundaries. Journal of Brand Management, 13(2):96-100

Farquhar, P. H. (1990). Managing brand equity. Journal of Advertising Research, 30(3):RC7-RC12

Fehlmann, R., Grahlow, H., Lutz, A., Passow, T. and Schierscher, R. (2002). Leichtenstein: Introducing the global village. linking reputation, identity and communication. MPR4 Research Project Report. Lugano: University of Lugano

Feldwick, P. (1996). What is brand equity anyway, and how do you measure it? Journal of the Market Research Society, 38(2):85-104 
Filion, L. J. (1991). Vision and relations: elements for an entrepreneurial metamodel. International Small Business Journal, 9(2):26-40

Florek, M. (2005). The country brand as a new challenge for Poland. Place Branding, 1(2):205-14

Florek, M. and Conejo, F. (2007). Export flagships in branding small developing countries: the cases of Costa Rica and Moldova. Place Branding and Public Diplomacy, 3(1):53-72

Fombrun, C. (1996). Reputation: realizing value from the corporate image. Boston: Harvard Business School Press

Francis, P. R. (2007). Changing "Brand Africa”. International Trade Centre, International Trade Forum, Issue (1)

Francis, A. (1992). The process of national industrial regeneration and competitiveness. Strategic Management Journal, 13(Winter):61-78

Frasher, S., Hall, M., Hildreth, J. and Sorgi, M. (2003). A brand for the nation of Latvia. Oxford: Oxford Said Business School

Freeman, R. E. (1984). Strategic management: a stakeholder approach. Boston: Pitman

Freeman, R. E. (1997). A stakeholder theory of the modern corporation. In: Beauchamp, T. L. and Bowie, N. E. eds. (1997). Ethical Theory and Business. New Jersey: PrenticeHall,p.66-76

Freire, J. R. (2005). Geo-branding, are we talking nonsense? A theoretical reflection on brands applied to places. Place Branding, 1(4):347-62

Fukuyama, F. (2004). State-building: governance and world order in the 21 st century. New York: Cornell University Press

GAO Report (2003). U.S. PUBLIC DIPLOMACY-State Department expands efforts but faces significant challenges. 〈http://www.gao.gov/new.items/d03951.pdf>

Georgescu, A and Botescu, A. (2004). Branding national identity. Lund: Lund University

Gersbach; H. (2002). Globalization at the industry level. TheWorld Economy, 25(2): 20929

Gertner, D. (2007). Place branding: Dilemma or reconciliation between political ideology and economic pragmatism? Place Branding and Public Diplomacy, 3(1):3-7

Gertner, D. and Kotler, P. (2004). How can a place correct a negative image? Place Branding, 1(1):50-57 
Gill, S. (2002). Power and resistance in the New World Order. London: Palgrave

Gill, J. and Johnson, P. (2002). Research methods for managers. $3^{\text {rd }}$ ed. London: Paul Chapman

Gilmore, F. (2002). A country - can it be repositioned? Spain - the success story of country branding. Journal of Brand Management, 9(4/5):281-93

Gladwin, T. N., Kennelly, J. J. and Tara-Shelomith Krause, T. S. (1995). Shifting paradigms for sustainable development:implications for management theory and research. The Academy of Management Review, 20(4):874-907

Glaser, B. and Strauss, A. (1967). The discovery of grounded theory. Chicago: Aldine

Glennan, S. (1996). Mechanisms and the nature of causation. Erkenntnis, 44:49-71

Gluck, F.W. (1984). Vision and leadership. Interfaces, 14(1):10-18

Gnoth, J. (2002). Leveraging export brands through a tourism destination brand. Journal of Brand Management, 9(4/5):262-80

Gold, E. R. (2006). Intellectual architecture as place brand. Place Branding, 2(3):220-28

Gould, M. and Skinner, H. (2007). Branding on ambiguity? Place branding without a national identity: marketing Northern Ireland as a post-conflict society in the USA. Place Branding and Public Diplomacy, 3(1):100-13

Gudjonsson, H. (2005). Nation branding. Place Branding, 1(3):283-98

Guerrini, S. (2005). Branding the nation or branding the country.

<http://www.icograda.org/web/feature-current.shtml>

Hair, J., Money, A., Page, M. and Samouel, P. (2007). Research methods for business. West Sussex: John Wiley \& Sons

Hafhill, D.S. (1980). Multinational marketing strategy: implications for attitudes toward country of origin. Management International Review, 20(4):26-30

Hall, P. A. (2006). Systematic process analysis: when and how to use it. European Management Review, 3:24-31

Hall, D. (2002). Brand development, tourism and national identity: the re-imaging of former Yugoslavia. Journal of Brand Management, 9(4/5):323-34

Hall, R (1992). The strategic analysis of intangible resources. Strategic Management Journal, 13(2):135-44 
Hamel, G. and Prahalad, C. K. (1989). Strategic intent. Harvard Business Review, 67(3):63-74

Hamlin, R. P. and Leith, K. J. (2006). Studying the country-of-origin cue in action: a experimental examination of wine evaluations in the United Kingdom and New Zealand. Place Branding, 2(4):311-20

Han, C. M. (1990). Testing the role of country image in consumer choice behaviour. European Journal of Marketing, 24(6):24-40

Han, C. M. and Terpstra, V. (1988). Country-of-origin effects for uni-national and binational products. Journal of International Business Studies, 19(2):235-55

Hanna, K. S. (2005). Planning for sustainability. Journal of the American Planning Association, 71(1):27-40

Hankinson, G. (2007). The management of destination brands: Five guiding principles based on recent developments in corporate branding theory. Journal of Brand Management, 14(3):240-54

Hankinson, G. (2004). Relational network brands: towards a conceptual model of place brands. Journal of Vacation Marketing, 10(2):109-21

Hankinson, G. and Cowking, P. (1996). The reality of global brands. London: McGrawHill

Hardy C. (1994). Managing strategic action. London: Sage

Harzing, A. W. K. and Sorge, A. M. (2003). The relative impact of country-of-origin and universal contingencies on internationalization strategies and corporate control in multinational enterprises: Worldwide and European perspectives. Organisation Studies, 24(2):187-214

Hirst, P. (1997). The global economy - myths and realities. International Affairs, 73(3): 409-25

HMSO (1985). Report from the select committee of the House of Lords on overseas trade. London: The Aldington Report

Hooley, G. J., Lynch, J. E., Brooksbank, R. W. and Shepherd, J. (1988). Strategic market environments. Journal of Marketing Management, 4(2):131-47

Hughes, K. S. (1993). Introduction: internalization, integration and European competitiveness. In: Hughes, K.S. eds. (1993). European Competitiveness. Cambridge University Press,p.1-7 
Huysman, M. H., Fischer, S. J. and Heng, M. S. (1994). An organizational learning perspective on information systems planning. Journal of Strategic Information Systems, 3:165-77

Ietto-Gillies, G. (2005). Transnational corporations and international production: concepts, theories and effects. Cheltenham: Edward Elgar

Ind, N. and Watt, C. (2004). Inspiration: capturing the creative potential of your organization. Basingstoke: Palgrave Macmillan

Interbrand (2007). BusinessWeek/Interbrand 2007 annual ranking the Top 100 global brands

IMD (2005). The World Competitiveness Yearbook 2005. Geneva: The International Institute for Management Development

Jaffe, E. D. and Nebenzahl, I. D. (2006). National image \& competitive advantage. $2^{\text {nd }}$ ed. Denmark: Copenhagen Business School Press.

Jaworski, S. P. and Fosher, D. (2003). National brand identity and its effect on corporate brands: the nation brand effect (NBE). Multinational Business Review, 11(2):99-108

Joachimsthaler, E. and Aaker, D. A. (1997). Building brands without mass media. Harvard Business Review, 75(1):39-50

Johnson, G., Scholes, K. and Whittington, R. (2005). Exploring corporate strategy. $7^{\text {th }}$ ed. London: Prentice Hall

Johnson, G. and Scholes, K. (1999). Exploring corporate strategy. $5^{\text {th }}$ ed. London: Prentice Hall

Johansson, J. K., Douglas, S. P. and Nonaka, I (1985). Assessing the impact of country of origin on product evaluations: a new methodological perspective. Journal of Marketing Research, 22(November):388-96

Jones, R. (2005). Finding sources of brand value: developing a stakeholder model of brand equity. Journal of Brand Management, 13(1):10-32

Kang, G. H. (2000). 경제개발 5 개년 계획: 목표 및 집행의 평가. 서울:서울대학교 출판부

Karakaya, F. and Stahl, M. J. (1989). Barriers to entry and market entry decisions in consumer and industrial goods markets. Journal of Marketing, 53(2):80-91

Kaul, I., et al. (2003). Providing global public goods; managing globalization. New York: Oxford University Press

Kavaratzis, M. and Ashworth, G. J. (2005). City branding: an effective assertion of identity or a transitory marketing trick? Journal of Economic \& Social Geography, 96(5):506-14 
Keller, K. L. (2003). Strategic brand management: building, measuring, and managing brand equity. New Jersey: Prentice-Hall

Keller, K. L. (2001). Brand research imperatives. Journal of Brand Management, 9(1): 4-6

Keller, K. L. (1998). Strategic brand management: building, measuring and management brand equity. New Jersey: Prentice-Hall

Kerr, G. (2006). From destination brand to location brand. Journal of Brand Management, 13(4/5):276-83

Kerr, G. and Johnson, S. (2005). A review of a brand management strategy for a small town-Lessons learnt! Place Branding, 1(4):373-87

Kidder, L. H. and Judd. C. M. (1986). Research Methods in Social Relations. $5^{\text {th }}$ ed. New York: Holt

Kitchin, T. (2003). Brand sustainability: it's about life...or death. In: Ind, N. eds. (2003). Beyond Branding. London: Kogan Page,p.69-86

Knight, G. A. and Cavusgil, S. T. (2004). Innovation, organization capabilities, and the born-global firm. Journal of International Business Studies, 35(2):124-41

Konecnik, M. and Go, F. (2008). Tourism destination brand identity: the case of Slovenia. Journal of Brand Management, 15(3):177-89

Konecnik, M. (2004). Evaluating Slovenia's image as a tourism destination: selfanalysis process toward building a destination brand. Journal of Brand Management, 11(4):307-16

Korea Brand Conference. Seoul: The Institute for Industrial Policy Studies

Kotabe, M. and Helsen, K. (2000). Global Marketing Management. $2^{\text {nd }}$ ed. New York: John Wiley

Kotler, P. and Keller, K. L. (2006). Marketing Management. $12^{\text {th }}$ ed. New Jersey: Pearson Education-Prentice Hall

Kotler, P., et al (2004). Opinion pieces 'In response to the question: where is place branding heading?’ Place Branding, 1(1):12-35

Kotler, P. and Gertner, D. (2002). Country as brand, product, and beyond: a place marketing and brand management perspective. Journal of Brand Management, 9(4/5): 24961

Kotler, P., Asplund, C., Rein, I. and Haider, D. (1999). Marketing places Europe. London: Pearson Education 
Kotler, P., Jatusripitak, S. and Maesincee, S. (1997). The marketing of nations. a strategic approach to building national wealth. New York: Free Press

Kotler, P., Haider D. and Rein, I. (1993). Marketing places. attracting investment, industry and tourism to cities, states, and nations. New York: Maxwell Macmillan

Krugman, P.R. (1996). Making sense of the competitiveness debate. Oxford Review of Economic Policy, 12(3):17-25

Kyriacou, S. and Cromwell, T. (2004). Branding nations the concepts and benefits of nation branding. <http:// www.eastwestcoms.com>

Lampert, S. I. and Jaffe, E. D. (1998). A dynamic approach to country of origin effect. European Journal of Marketing, 32(1/2):61-78

Lebedenko, V. (2008). On national identity and the building of Russia's image. In: Dinnie, K. (2008). Nation Branding: concepts, issues, practice. Oxford: ButterworthHeinemann,p.107-11

Leclerc, F., Schmitt, B. H. and Dubé, L. (1994). Foreign branding and its effects on product perceptions and attitudes. Journal of Marketing Research, 31(2):263-70

Lee, K. M., Cho, D. S. and De Boer, S. (2006). Measuring the performance in nation branding: capability, stakeholders and identity-oriented views. The European International Business Academy (EIBA) 2006 Conference

Lenway, S. A. and Murtha, T. P. (1994). The State as strategist in international business literature. Journal of International Business Studies, 25(3):513-36

Leonard-Barton, D. (1988). Synergic design for case studies: longitudinal single-site and replicated multiple-site. The National Science Foundation Conference on Longitudinal Research Methods in Organizations

Leonard, M. (2002). Diplomacy by other means. Foreign Policy, 132(Sep-Oct):48-56

Leonard, M.; Stead, C. and Smewing, C. (2002). Public diplomacy. London: Foreign Policy Centre

Leonard, M., Small, A. and Rose, M. (2005). British public diplomacy in the 'age of schisms'. London: Foreign Policy Centre. < http://fpc.org.uk/fsblob/407.pdf>

LePla, F. J. and Parker, L. M. (2002). Integrated branding: becoming brand-driven through company-wide action. London: Kogan Page

Levary, R. R. and Choi, T. S. (1983). A linear goal programming for planning the exports of emerging countries. Journal of Operational Research Society, 34:1057-67 
Lindsay, M. (2004). The brand called Wisconsin: can we make it relevant and different for competitive advantage. WI: Lindsay, Stone and Briggs

Lodge, C. (2006). Opinion pieces 'How has place branding developed during the year that place branding has been in publication?’ Place Branding, 2(1):6-17

Lodge, C. (2002). Success and failure: the brand stories of two countries. Journal of Brand Management, 9(4/5):372-84

Lorino, P. and Tarondeau, J. C. (2002). From resources to processes in competence-based strategic management. In: Morecroft, J., Sanchez, R. and Heene, A. eds. (2002). Systems Perspectives on Resources, Capabilities, and Management Processes. London: Pergamon,p.127-52

Loo, T. and Davies, G. (2006). Branding China: the ultimate challenge in reputation management? Corporate Reputation Review, 9(3):198-210

Louro, M. J. and Cunha, P. V. (2001). Brand management paradigms. Journal of Marketing Management, 17:849-75

Luthans, F. and Stewart, T. I. (1977). A general contingency theory of management. Academy of Management Review, 2(2):181-95

Machamer, P., Darden, L. and Craver, C. (2000). Thinking about mechanisms. Philosophy of Science, 67(1):1-25

Mackenzie, K. D. (2000). Knobby analyses of knobless survey items, part I: the approach. International Journal of Organizational Analysis, 8(2):131-54

MacMillan, K., Money, K., Downing, S. and Hillenbrand, C. (2005). Reputation in relationships: measuring experiences, emotions and behaviors. Corporate Reputation Review, 8(3):214-33

Macrae, C. (2008). The coming crisis in the geography-chained market of nations. In: Dinnie, K. (2008). Nation Branding: concepts, issues, practice. Oxford: ButterworthHeinemann, p.245-46

Malina, M. A. and Selto, F. H. (2003). Causality in performance measurement model. $<$ http://ssrn.com/abstract=488144>

Markus, L. M. and Robey, D. (1988). Information technology and organizational change: causal structure in theory and research. Management Science, 34(5):583-98

Martensen, A. and Gronholdt, L. (2005). Analysing customer satisfaction data: a comparison of regression and artificial neural networks. International Journal of Market Research, 47(2):121-30 
Martinovic, S. (2002). Branding Hrvatska - a mixed blessing that might succeed: the advantage of being unrecognizable. Journal of Brand Management, 9(4/5):315-22

Melin, L. (1992). Internationalization as a strategy process. Strategic Management Journal, 13(Special Issue):99-118

Melissen, J. (2006). Opinion pieces 'How has place branding developed during the year that place branding ha sbeen in publication?’ Place Branding, 2(1):6-17

Mihailovich, P. (2006). Kinship branding: a concept of holism and evolution for the nation brand. Place Branding, 2(3):229-47

Miles, M. B. and Hubermann, A. M. (1994). Qualitative data analysis. $2^{\text {nd }}$ ed. Thousand Oaks, CA: Sage

Milfelner, B., Gabrijan, V. and Snoj, B. (2008). Can marketing resources contribute to company performance? Organizacija, 41(1):3-13

Morgan, N. and Pritchard, A. (2004). Meeting a destination branding challenge. In:

Morgan, N., Pritchard, A. and Pride, R. eds. (2004). Destination branding. $2^{\text {nd }}$ ed. Oxford: Elsevier, p.59-78

Morgan, N., Pritchard, A. and Piggott, R. (2002). New Zealand, 100\% pure. the creation of a powerful niche destination brand. Journal of Brand Management, 9(4/5):335-54

Munoz, T. and Kumar, S. (2004). Brand metrics: gauging and linking brands with business performance. Brand Management, 11(5):381-87

Murtha, T. P. and Lenway, S. A. (1994). Country capabilities and the strategic state: how national political institutions affect multinational corporations' strategies. Strategic Management Journal, 15(Sum):113-29

Nagashima, A. (1970). A comparison of Japanese and U.S. attitudes toward foreign products. Journal of Marketing, 34 (January):68-74

Nebenzahl, I. D., Jaffe, E. D. and Lampert, S. I. (1997). Towards a theory of country image effect on product evaluation. Management International Review, 37(1):27-49

Nebenzahl, I. (2004). Opinion pieces 'Where is place branding heading?' Place Branding, $1(1): 12-35$

Newman, M. and Robey, D. (1992). A social process model of user-analyst relationships. MIS Quarterly, 16(2):249-66

Noya, J. (2006). The symbolic power of nations. Place Branding, 2(1):53-67

Nye, J. S. (1992). What New World Order? Foreign Affairs, 71(2):83-96 
O, W.C. (1995).한국형 경제건설:엔지니오링 어프로치, 제 1-5권. 서울:기아경제연구소

OECD (1992). The tTechnology and the economy. the key relationships. Paris: OECD

Olins, W. (2002). Branding the nation - the historical context. Journal of Brand Management, 9(4/5):241-48

Olins, W. (1999). Trading identities: why countries and companies are taking on each other's roles. London: Foreign Policy Center

O'Donovan, D. (2004). Opinion pieces 'Where is place branding heading?' Place Branding, 1(1):30-32

Orlikowski, W. U. (2002). Knowing in practice: enacting a collective capability in distributed organizing. Organization Science, 13(3):249-73

O'Shaughnessy, J. and O'Shaughnessy, N. J. (2000). Treating the nation as a brand: some neglected issues. Journal of Macromarketing, 20(1):56-64

Oxford Concise English Dictionary. $11^{\text {th }}$ ed. edited by Soanes, C. and Stevenson, A.

Pant, D.R. (2008). Re-positioning Nepal in global public opinion and markets: placebranding for sustainable economic development. In: Dinnie, K. (2008). Nation Branding: concepts, issues, practice. Oxford: Butterworth- Heinemann, p.50-51

Pant, D. R. (2005). A place brand strategy for the Republic of Armenia: 'quality of context' and 'sustainability' as competitive advantage. Place Branding, 1(3):273-82

Pantzalis, J. and Rodrigues, C. A. (1999). Country names as brands: symbolic. meaning and capital flows. 〈http://www.sba.muohio. edu/abas/1999/pantzajo.pdf.>

Papadopoulos, N. (2004). Place branding: evolution, meaning and implications. Place Branding, 1(1):36-49

Papadopoulos, N. and Heslop, L. A. (2002). Country equity and country branding: problems and prospects. Journal of Brand Management, 9(4/5):294-314

Papadopoulos, N. (1993). What product and country images are and are not. In: Papadopoulos, N. and Heslop, L. eds. (1993). Product-Country Images Impact and Role in International Marketing. London: Haworth Press, p.3-38.

Parameswaran, R. and Pisharodi, R. (1994). Facets of country of origin image: an empirical assessment. Journal of Advertising, 23(1):43-56

Park, C. S. and Srinivasan, V. (1994). A survey-based method for measuring and understanding brand equity and its extendibility. Journal of Marketing Research, 31(2):271-88 
Parkerson, B. (2007). From schlock to hot: shifting perceptions of Brooklyn. Place Branding and Public Diplomacy, 3(4):263-67

Pasquier, M. (2008). The image of Switzerland: between cliches and realities. In: Dinnie, K. (2008). Nation Branding: concepts, issues, practice. Oxford: Butterworth- Heinemann, p.79-84

Passow, T., Fehlmann, R. and Grahlow, H. (2005). Country reputation - from measurement to management: the case of Liechtenstein. Corporate Reputation Review, 7(4):309-26

Peng, M. W. (2004). Identifying the big question in international business research. Journal of International Business Studies, 35(2):99-108

Perry, R. and Robertson, J. (2002). Comparative analysis of nations: quantitative approaches. New York: HarperCollins

Peterson, R. A. and Jolibert, A. J. (1995). A meta-analysis of country-of-origin effects. Journal of International Business Studies, 26(4):883-900

Pickton, D. (2008). What is a brand worth? Journal of Brand Management, 15(3):155-6

Pidd, M. (1996). Tools for thinking: modelling in management science. Chichester: John Wiley \& Sons

Piore, M. J. (2006). Qualitative research: does it fit in economics? European Management Review, 3:17-23

Porter, M. E. (2001). San Diego, clusters of innovation initiative. Washington DC: Council on Competitiveness (Monitor Group on the Frontier)

Porter, M. E. (1998). The competitive advantage of nations. London: The Macmillan Press

Porter, M. E. (1985). Competitive advantage: creating and sustaining superior performance. New York: Free Press

Porter, M. E. (1980). Competitive strategy. New York: Free Press

Pryor, S. and Grossbart, S. (2007). Creating meaning on main street: towards a model of place branding. Place Branding and Public Diplomacy, 3(4):291-304

Quelch, J. and Jocz, K. (2005). Positioning the nation-state. Place Branding, 1(3):229-37

Quelch, J. A. and Harding, D. (1996). Brand versus private labels: fighting to win. Harvard Business Review, 74(1):105-26

Rainisto, S. K. (2006). Opinion pieces 'How has place branding developed during the year that place branding has been in publication?' Place Branding, 2(1):6-17 
Rainisto, S. K. (2004). Opinion pieces 'Where is place branding heading?' Place Branding, $1(1): 12-35$

Rainisto, S. K. (2003). Success factors of place marketing: a study of place marketing practices in Northern Europe and the United States. Helsinki University of Technology

Reierson, C. (1966). Are foreign products seen as national stereotypes? Journal of Retailing, 42(Fall): 33-40.

Reszka, P. and Zdort, M. D. (2002). Jak sprzedaje sie,Polske, Rzeczpospolita, (No. 211)

Ries, A. and Trout, J. (1982). Positioning: the battle for your mind. New York: Warner Books

Risen, C. (2005). Re-branding America.

http://www.boston.com/news/globe/ideas/articles/2005/03/13/re branding america?pg=full

Ritchie, J. R. B. and Crouch, G. I. (2005). The competitive destination: a sustainable tourism perspective. Oxon: CABI Publishing.

Robson, C. (2002). Real world research. $2^{\text {nd }}$ ed. Oxford: Blackwell.

Roth, M. S. and Romeo, J. B. (1992). Matching product category and country image perceptions: a framework for managing country-of-origin effects. Journal of International Business Studies, 23(3):477-97

Ryder, I. (2003). Anthropology and the brand. In: Ind, N. eds. (2003). Beyond Branding. London: Kogan Page,p.139-60

Sachs, W. (1992). The development dictionary: a guide to knowledge as power. London: Zed Books

Samiee, S. (1994). Customer evaluations of products in a global market. Journal of International Business Studies, 25(3):579-604

Samiee, S., Shimp, T. A. and Sharma, S. (2005). Brand origin recognition accuracy: Its antecedents and consumers' cognitive limitations. Journal of International Business Studies, 36(4):379-97

Sanchez, R. (2002). Strategic management at the point of inflection: systems, complexity, and competence theory. In: Morecroft, J., Sanchez, R. and Heene, A. eds (2002). Systems Perspectives on Resources, Capabilities, and Management Processes. London: Pergamon,p.217-28

Sanchez, R. and Heene, A. (2002). Managing strategic change: a systems view of strategic organizational change and strategic flexibility. In: Morecroft, J., Sanchez, R. and Heene, A. eds. (2002). Systems Perspectives on Resources, Capabilities, and Management Processes. London: Pergamon,p.71-91 
Sanchez, R. (1997). Preparing for an uncertain future: managing organizations for organizational flexibility. International Studies of Management \& Organization, 27(2):7194

Saunders, M., Lewis, P. and Thornhill, A. (2007). Research methods for business students. $4^{\text {th }}$ ed. Essex: Prentice Hall

Schmitt, B. H. and Simonson, A. (1997). Marketing aesthetics: the strategic management of brands, identity, and image. New York: Free Press

Schooler, R. D. (1965). Product bias in the Central American common market. Journal of Marketing Research, 2(November):394-97

Scott, B. R. and Lodge, G. C. (1985). U.S. competitiveness in the World Economy. Boston: Harvard Business School Press

Senge, P., et al. (1994). Fifth Discipline: Fieldbook. London: Century Books

Shocker, T., Srivastava, S. and Ruekert, P. (1994). Challenges and opportunities facing brand management. Journal of Marketing Research, 31(May):149-58

Sinclair, R. (2004). A brand valuation methodology for nations. Place Branding, 1(1):74-79

Skinner, H. and Kubacki, K. (2007). Unravelling the complex relationship between nationhood, national and cultural identity, and place branding. Place Branding and Public Diplomacy, 3(4):305-16

Snow, N. (2004). Information war: American propaganda, free speech and opinion control since 9-11. New York: Seven Stories Press

Sousa, R. (2000). Quality management practice: universal or context dependent? an empirical investigation. London: London Business School

Strong, W. A. and Hemphill, L. (2006). Sustainable development policy: Directory. Oxford: Blackwell

Swanborn, P.G. (1996). Case-study's, wat, wanneer en hoe? Meppel: Boom

Szondi, G. (2008). Country promotion and image management-the case of Hungary. In: Dinnie, K. (2008). Nation Branding: concepts, issues, practice. Oxford: ButterworthHeinemann,p.201-04

Szondi, G. (2007). The role and challenges of country branding in transition countries: the Central and Eastern European experience. Place Branding and Public Diplomacy, 3(1):820 
Teece, D., Pisano, G. and Shuen, A. (1997). Dynamic capabilities and strategic management. Strategic Management Journal, 18(7):509-33

The Medinge Group (2002). The brand manifesto.

<http://www.jyanet.com/cap/2002/0909fe0.shtml>

Temporal, P (2001). Why Asian countries need branding. <http:// www. Asian.com>

Therkelsen A. and Halkier H. (2004). Umbrella place branding. a study of friendly exoticism and exotic friendliness in coordinated national tourism and investment promotion. Aalborg University: SPIRIT Discussion Paper, 26

Trappey III, R. J. and Woodside, A. G. (2005): Consumer responses to interactive advertising campaigns coupling short-message-service direct marketing and TV commercials. Journal of Advertising Research, 45(4):382-402

Tsoukas, H. (1989). The validity of idiographic research explanations. Academy of Management Review, 14(4):551-61

UNCTAD (2008). World Investment Report 2008: Transnational corporations and the infrastructure challenge. Geneva: UNCTAD

UNCTAD (2006). World Investment Report 2006: FDI from developing and transition economies. Geneva: UNCTAD

UNCTAD (2005). World Investment Report 2005: transnational corporations and the internationalization of $R \& D$. Geneva: UNCTAD

UNCTAD (2004). World Investment Report 2004: the shift towards services. Geneva: UNCTAD

UNCTAD (2002). World Investment Report 2002: transnational corporations and export competitiveness. Geneva: UNCTAD

UNCTAD (2001). World Investment Report 2001: promoting linkages. Geneva: UNCTAD

UNCTAD (1999). World Investment Report 1999: foreign direct investment and the challenge of development. Geneva: UNCTAD

UNCTAD (1991). World Investment Report 1991: the Triad in Foreign Direct Investment. Geneva: UNCTAD

United Nations Development Programme (UNDP) (2005). Human Development Report 2005. New York: UNDP

United Nations Development Programme (UNDP) (1998). Human Development Report 1998: Consumption for Human Development. New York: UNDP 
United Nations Research Institute for Social Development (UNRISD) (1995). States of disarray: the social effects of globalization. An UNRISD Report for the World Summit for Social Development

Upshaw, L. (1995). Building brand identity: a strategy for success in a hostile market place. New York: John Wiley and Sons

Ursache, M. (2003)

http://www.logolounge.com/articles/default.asp?Archive=True\&ArticleID=292

Usunier, J. C. (2006). Relevance in business research: the case of country-of-origin research in marketing. European Management Review, 3(1):60-73

Van de Ven, A. H. (1992). Suggestions for studying strategy process: a research note. Strategic Management Journal, 13(Summer):169-88

Van de Ven, A. H. and Huber, G. P. (1990). Longitudinal field research methods for studying processes of organizational change. Organization Science, 1(3):213-19

Van de Ven, A. H. and Poole, M. S. (1990). Methods for studying innovation development in the Minnesot Innovation Research Program. Organization Science, 1(3): 313-35

Van Gelder, S. (2005). The new imperatives for global branding: strategy, creativity and leadership. Journal of Brand Management, 12(5):395-404

Van Ham, P. (2004). Opinion pieces 'Where is place branding heading? Place Branding, $1(1): 12-35$

Verlegh, P. W. J. and Steenkamp, J. E. M. (1999). A review and meta-analysis of countryof-origin research. Journal of Economic Psychology, 20(5):521-46

Verschuren, P. and Doorewaard, H. (1999). Designing a research project. Utrecht: Lemma

Vietor, R. H. K. (2007). How countries compete: strategy, structure, and government in the global economy. Boston: Harvard Business School Press

Walsh, G. and Wiedmann, K. P. (2008). Branding Germany-managing internal and external country reputation. In: Dinnie, K. (2008). Nation Branding: concepts, issues, practice. Oxford: Butterworth-Heinemann, p.154-158

Wang, J. (2006). Localising public diplomacy: the role of sub-national actors in nation branding. Place Branding, 2(1):32-42

Webster Jr, F. E. and Keller, K. L. (2004). A roadmap for branding in industrial markets. Journal of Brand Management, 11(5): 388-402 
Wells, L. T. and Wint, A. (2000). Marketing a country: promotion as a tool for attracting foreign investment. The International Finance Corporation revised edition (FIAS Occasional Paper, 13)

Wetzel, F. (2006). Brand England. Place Branding, 2(2):144-54

White, P. D. and Cundiff, E. W. (1978). Assessing the quality of industrial products. Journal of Marketing, 42(January):80-86

Widler, J. (2007). Nation branding: with pride against prejudice. Place Branding and Public Diplomacy, 3(2):144-50

Wilkin-Armbrister, E. (2008). Brand Nevis-the role of the financial service sector. In: Dinnie, K. (2008). Nation Branding: concepts, issues, practice. Oxford: ButterworthHeinemann, p.97-101

Wolf, C. and Rosen, B. (2004). Public Diplomacy: how to think about and improve it. $<$ http://www.publicdiplomacy.org/36.htm>

Wood, L. (2000). Brands and brand equity: definition and management. Management Decision, 38(9):662-69

World Bank (2006). World Bank Atlas Method

World Economic Forum (1996). Global Competitiveness Report 1996. Geneva: World Economic Forum

Yamaguchi, K. (1991). Event history analysis. CA: SAGE

Yan, J. (2003). Branding and the international community. Journal of Brand Management, $10(6): 447-56$

Yin, R. K. (2003). Case study research. $3^{\text {rd }}$ ed. Beverly Hills: Sage

Zerrillo, P. C. and Thomas, G. M. (2007). Developing brands and emerging markets: An empirical application. Place Branding and Public Diplomacy, 3(1):86-99

Zukin, S. (1993). Landscapes of power. Berkeley: University of California Press 


\section{APPENDIX: DATA COLLECTION PROTOCOL}

\section{A1. SCHEME FOR DATA COLLECTION PROCEDURE}

To collect data for branding of Korea and Ireland and to analyse the collected data, we design the case study schedule in the following steps:

\begin{tabular}{|c|l|}
\hline & \multicolumn{1}{|c|}{ Procedure } \\
\hline Step1 & $\begin{array}{l}\text {-Benchmarking and analysing the secondary data from the leading international data } \\
\text { agencies }\end{array}$ \\
\hline Step2 & $\begin{array}{l}\text {-Gathering information for questionnaire and writing questions } \\
\text {-Contacting key informants from case countries }\end{array}$ \\
\hline Step3 & $\begin{array}{l}\text {-Visiting the governments and promotion agencies } \\
\text {-Interviewing face to face, telephone and email }\end{array}$ \\
\hline Step4 & $\begin{array}{l}\text {-Analyzing interview results } \\
\text {-Preparing the additional data collection }\end{array}$ \\
\hline Step5 & $\begin{array}{l}\text {-Collecting the documents } \\
\text {-Interviewing informants for additional data }\end{array}$ \\
\hline Step6 & -Writing the case description \\
\hline
\end{tabular}

\section{A2. INTERVIEW QUESTIONS}

Section A2 addresses the interview questions. The questionnaire has been composed on the basis of the paper "Measuring the Performance in Nation Branding: Capability, Stakeholders and Identity-Oriented Views (Lee, Cho \& De Boer, 2006)" which was presented in The European International Business Academy (EIBA) 2006 Conference. Questionnaire is as follows:

\begin{tabular}{|c|c|}
\hline NO. & Questions \\
\hline BP-F1 & $\begin{array}{l}\text { How has your country been cognitively recognized by TNCs (Transnational Corporations) during } \\
\text { attracting FDI? }\end{array}$ \\
\hline BP-F2 & $\begin{array}{l}\text { How has your country been emotionally been affinitive to TNCs (Transnational Corporations) during } \\
\text { attracting FDI? }\end{array}$ \\
\hline BS-F1 & How much has your country accomplished the main goals in terms of attracting FDI? \\
\hline BS-F2 & $\begin{array}{l}\text { How much has your country achieved the economic \& non-economic outcomes in terms of attracting } \\
\text { FDI? }\end{array}$ \\
\hline BP-E1 & How has your country been cognitively recognized by the global markets during Export activities? \\
\hline BP-E2 & How has your country been emotionally been affinitive to the global markets during Export activities? \\
\hline BS-E1 & How much has your country accomplished the main goals in terms of Export activities? \\
\hline BS-E2 & $\begin{array}{l}\text { How much has your country achieved the economic \& non-economic outcomes in terms of Export } \\
\text { activities? }\end{array}$ \\
\hline & At the beginning of establishing brand vision: identifying brand resource: \\
\hline BI-I & $\begin{array}{l}\text { What kinds of the attractive industries were available in your country? } \\
\text { (Please select three of them as the priority) } \\
\text { 1. Tourism } \\
\text { 2. Textile \& Leader } \\
\text { 3. Agriculture, Forestry and Fisheries }\end{array}$ \\
\hline
\end{tabular}




\begin{tabular}{|c|c|}
\hline & $\begin{array}{l}\text { 4. ICT } \\
\text { 5. Electronics and electrical } \\
\text { 6. Construction } \\
\text { 7. Pharmaceutical \& biotech } \\
\text { 8. Transport service } \\
\text { 9. Engineering \& machinery } \\
\text { 10. Automotive } \\
\text { 11. Energy } \\
\text { 12. Food \& beverages } \\
\text { 13. Wood \& wood products } \\
\text { 14. Mining \& petroleum extraction } \\
\text { 15. Finance } \\
\text { 16. Steel \& other metals } \\
\text { 17. Petroleum products } \\
\text { 18. Chemicals } \\
\text { 19. Health \& social services } \\
\text { 20. Marketing or consulting services } \\
\text { 21. Other }\end{array}$ \\
\hline BI-P & $\begin{array}{l}\text { What kinds of physical elements were available in your country? } \\
\text { (Please choose three of them as priority) } \\
\text { 1. Endowed Resources (e.g. natural resources, capital resources, outbound investment, etc) } \\
\text { 2. Demand Condition (e.g. market size, demand quality, etc) } \\
\text { 3. Related \& Supporting Industry (e.g. infrastructure such as transportation, communication, etc) } \\
\text { 4. Business Context (e.g. firm strategy \& structure, Labour's quality and quantity, etc) } \\
\text { 5. Quality of Life (e.g. material well-being, political stability \& security, community life, etc) }\end{array}$ \\
\hline BI-C & $\begin{array}{l}\text { What kinds of natural or intrinsic elements were available in your country? } \\
\text { (Please choose three of them as priority) } \\
\text { 1. The spirit or emotion of the people } \\
\text { 2. Shared vision } \\
\text { 3. The openness of the people } \\
\text { 4. The elite ownership } \\
\text { 5. Loyalty in people's mind } \\
\text { 6. Vision and values of Korea leaders } \\
\text { 7. Cultural diversity } \\
\text { 8. Others }\end{array}$ \\
\hline BI-S & $\begin{array}{l}\text { What kinds of national symbol were easily recognized and recalled? } \\
\text { (Please choose three of them as priority)___ } \\
\text { 1. Word Mark } \\
\text { 2. Flag symbol } \\
\text { 3. Coat of Arms } \\
\text { 4. Characters } \\
\text { 5. Typefaces } \\
\text { 6. Colours } \\
\text { 7. Uniforms } \\
\text { 8. Product brand names } \\
\text { 9. Company names } \\
\text { 10. City brands } \\
\text { 11. Landmarks such as Architecture } \\
\text { 12. Name of Country } \\
\text { 13. Other_ }\end{array}$ \\
\hline
\end{tabular}




\begin{tabular}{|c|c|}
\hline \multicolumn{2}{|r|}{ At the beginning of establishing brand vision: Defining TNCs Motivation: } \\
\hline $\begin{array}{l}\text { TNC- } \\
\text { MF }\end{array}$ & What was the main motivation of TNCs investing to your country? \\
\hline TNC-E & What was the main motivation of TNCs exporting from your country? \\
\hline \multicolumn{2}{|r|}{ Establishing brand vision: } \\
\hline BV1 & What was nation's vision? \\
\hline BV2 & What was brand vision representing your country uniquely? \\
\hline BV3 & In what standpoint does brand vision reflect your country's brand identity? \\
\hline BV4 & In what standpoint does brand vision reflect TNCs motivation? \\
\hline BV5 & $\begin{array}{l}\text { Who (i.e. Brand Stewards) has mainly managed and taken responsibilities establishing brand vision? } \\
\text { (Please select three of them as priority) } \\
\text { 1. Embassies and consulates } \\
\text { 2. International enterprises } \\
\text { 3. Domestic enterprises } \\
\text { 4. National governments } \\
\text { 5. Local and state governments } \\
\text { 6. Political parties } \\
\text { 7. National economic development agencies } \\
\text { 8. Local economic development agencies } \\
\text { 9. National tourist boards } \\
\text { 10. Local tourist boards } \\
\text { 11. Investment promotion agency } \\
\text { 12. Export promotion agency } \\
\text { 13. Individual citizens } \\
\text { 14. Design Agency } \\
\text { 15. The office of patent administration or law office } \\
\text { 16. Others (Non-Government Organizations, Non-Political Organizations, Academics, etc___ }\end{array}$ \\
\hline \multicolumn{2}{|r|}{ Building Brand Strategy: } \\
\hline BS1 & What has your country had brand strategy? \\
\hline BS2 & How has brand strategy reflected brand vision? \\
\hline BS3 & $\begin{array}{l}\text { How has brand strategy comprehended nation's strength, weakness, opportunity and threat what Ireland } \\
\text { has had uniquely? }\end{array}$ \\
\hline BS4 & $\begin{array}{l}\text { Targeting on the branding project, how can you present the strategic directions on the basis of brand } \\
\text { vision? }\end{array}$ \\
\hline BS5 & In planning brand strategy, how actively have you involved TNCs? \\
\hline BS6 & In planning brand strategy, on which level have you involved TNCs? \\
\hline BS7 & How did brand strategy reflect the demand of TNCs? \\
\hline BS8 & How has brand identity been analyzed in building brand strategy? \\
\hline BS9 & How has brand strategy comprehended on protecting brand identity? \\
\hline BS10 & How has brand strategy comprehended on promoting brand identity? \\
\hline BS11 & What was the role of brand stewards building brand strategy? \\
\hline \multicolumn{2}{|r|}{ Implementing brand policy: } \\
\hline P1 & How can you describe brand policy in terms of attracting FDI? \\
\hline P2 & How can you describe brand policy in terms of supporting export activities? \\
\hline P3 & Who has been involved building brand policy? \\
\hline P4 & Who has operated brand policy in the focal position? \\
\hline P5 & How has FDI policy focused on specific target? \\
\hline P6 & How has Export policy focused on specific target? \\
\hline P7 & How has FDI policy maintained the consistency with export policy? \\
\hline P8 & How has FDI \& Export policies maintained the consistency with national development policy? \\
\hline P9 & How has FDI \& Export policies maintained the consistency with foreign policy? \\
\hline
\end{tabular}




\begin{tabular}{|l|l|}
\hline P10 & Who has been involved maintaining the consistency in policies? \\
\hline P11 & Who has operated in the focal position? \\
\hline P12 & How has your country considered maintaining and expanding TNCs' value? \\
\hline P13 & How have the standard operating procedures focused on interacting with targeted TNCs? \\
\hline P14 & How have the new ideas been adopted or pursued? \\
\hline P15 & How have the targeted competitors been considered? \\
\hline P16 & How has the cost efficiency been pursued? \\
\hline P17 & How has Design agency creatively represented brand identity? \\
\hline P18 & How has Promotion Agency reflected the changing (foreign \& domestic) corporate strategies? \\
\hline P19 & $\begin{array}{l}\text { What are the main targets (industries, activities, countries, companies, individuals, managers, or CEO) } \\
\text { for promotion? }\end{array}$ \\
\hline P20 & $\begin{array}{l}\text { How has Promotion Agency communicated the promotional messages, through advertising, public } \\
\text { relations event or news stories, what Ireland has authentically had? }\end{array}$ \\
\hline P21 & How has your country protected intellectual properties what TNCs have produced? \\
\hline P22 & How has financial investment been allocated for attracting TNCs investment? \\
\hline P23 & How has financial investment been allocated for supporting TNCs export activities? \\
\hline P24 & Who has been involved in designing, promoting and protecting brand identity? \\
\hline P25 & Who has operated in the focal position? \\
\hline
\end{tabular}

\section{A3. CASE STUDY REPORT}

\begin{tabular}{|c|c|}
\hline Branding of Korea & Branding of Ireland \\
\hline Section 1 Background & Section 1 Background \\
\hline Section 2 Case study design & Section 2 Case study design \\
\hline $\begin{aligned} \text { Section } 3 \text { Creating a Korea-brand vision (C-KBV) } \\
\text { - ESTI-I (1962-1971) } \\
\text { - ESTI-II (1972-1981) } \\
\text { - ESTI-III (1982-1997) }\end{aligned}$ & $\begin{aligned} & \text { Section } 3 \text { Creating an Ireland-brand vision (C-IBV) } \\
& \text { - FIEK-I (1987-1990) } \\
& \text { - FIEK-II (1991-1998) } \\
& \text { - FIEK-III (1999-2003) }\end{aligned}$ \\
\hline $\begin{aligned} \text { Section } 4 \text { Setting a Korea-brand goal (S-KBG) } \\
\text { - ESTI-I (1962-1971) } \\
\text { - ESTI-II (1972-1981) } \\
\text { - ESTI-III (1982-1997) }\end{aligned}$ & 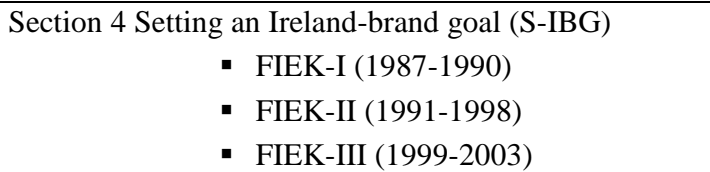 \\
\hline $\begin{aligned} \text { Section } 5 \text { Developing a Korea-brand strategy (D-KBS) } \\
\text { - ESTI-I (1962-1971) } \\
\text { - ESTI-II (1972-1981) } \\
\text { - ESTI-III (1982-1997) }\end{aligned}$ & $\begin{aligned} \text { Section } 5 \text { Developing an Ireland-brand strategy(D-IBS) } \\
\text { - FIEK-I (1987-1990) } \\
\text { - FIEK-II (1991-1998) } \\
\text { - FIEK-III (1999-2003) }\end{aligned}$ \\
\hline $\begin{aligned} \text { Section } 6 \text { Operating a Korea-brand strategy (O-KBS) } \\
\text { - } \text { ESTI-I (1962-1971) } \\
\text { - ESTI-II (1972-1981) } \\
\text { - ESTI-III (1982-1997) }\end{aligned}$ & $\begin{aligned} & \text { Section } 6 \text { Operating an Ireland-brand strategy (O-IBS) } \\
& \text { - } \text { FIEK-I (1987-1990) } \\
& \text { - FIEK-II (1991-1998) } \\
& \text { - FIEK-III (1999-2003) }\end{aligned}$ \\
\hline Section 7 Sustenance of competitiveness of Korea & Section7 Sustenance of competitiveness of Ireland \\
\hline Section 8 Conclusions & Section 8 Conclusions \\
\hline
\end{tabular}




\section{A4. PRIMARY AND SECONDARY DATA SOURCES}

\section{BRANDING OF KOREA}

-Key Informants

Jung, M. G. Ministry of Commerce Industry and Energy, Seoul

Kim, D. H. Korea Institute for Industrial Economics and Trade, Seoul

Kim, S. W. Korea Trade- Investment Promotion Agency (KOTRA), London

O, S. G. Korea Trade- Investment Promotion Agency (KOTRA), Seoul

-Korea Five-Year Plans

:제 1 차경제개발 5 개년계획평가보고서,1962-1966. 경제개발계획평가교수단 (1967)

:중간평가:제 1 차경제개발 5 개년계획. 국무총리기획조정실(1965)

:제 2 차경제개발 5 개년계획 계획자료. 경제기획원 (1966)

:제 2 차 경제개발 5 개년 계획 (1967-71). 대한민국정부 (1966)

:평가보고서: 제 2 차 경제개발 5 개년계획,제 1-2 차년도.경제개발계획평가교수단 (1968)

:제 2 차 경제개발 5 개년 계획 평가보고서. 평가교수단 (1972)

:제 3 차 경제개발 5 개년 계획 (1972-76). 대한민국정부 (1971)

:평가보고서, 1973-1974. 국무총리 기획조정실 (1973)

:평가보고서,1975-1976. 국무총리 기획조정실 (1975)

:제 4 차 경제개발 5 개년 계획(1977-1981).대한민국정부 (1976)

:평가보고서,1978-1981.국무총리 기획조정실 (1978)

:평가보고서: 제 4 차 경제개발 5 개년 계획 제 4 차년도 1981 , 제 2 편 산업부문.

국무총리기획조정실(1981)

:제 5 차 경제사회발전 5 개년 계획 (1982-86). 대한민국정부 (1981)

:제 5 차 경제사회발전 5 개년 계획-과학기술부문 수정계획(1984-1986). 과학기술처 (1983)

:제 6 차 경제사회발전 5 개년 계획- 상공부문계획 (1987-1991). 상공부 (1986)

:제 6 차 경제사회발전 5 개년 계획 - 대외협력부문계획 (1987-1991). 경제기획원 (1987)

:新경제 5 개년 계획(1993-1997)-參與와 創意로 새로운 跳躍을. 대한민국정부 (1993)

-경제기획원 (1981). 「경제백서」. 서울: 경제기획원.

-국가과학기술자문회의 (2006). 국가 R \& D가 지역균형에 미치는 효과분석 연구.

한국과학기술기획평가원

-국가재건최고회의의 2 차산업반심의위원회 편 (1962). 2차산업부문보고서

-국정홍보처.해외홍보원 (2005). 미국.독일·일본 3 개국 국가이미지 여론조사.

-국정홍보처.해외홍보원 (2006). 중국.인도.러시아 3 개국 국가이미지 여론조사 
-김갑수, 서정해, 한상영 (2000). A study on the Governmental Programs for Promoting Cooperative R\&D: Status and Future Direction. 과학기술정책연구원 -김광모 (1988). 한국의 산업발전과 중화학 공업화정책.서울: 지구문화사 -김도훈 (2006). Trade Promotion and Economic Development in Korea. 산업연구원 -김영두, 인수범, 김재우 (2002). 경제민주주의와 노동조합운동 (Economic Democracy \& Labor Movements). 한국노동사회연구소 -김왕식 (1995). 한국의 정부-이익집단의 관계패턴. In 안병준 외. 국가.시민사회.정치민주화. 서울: 한울, p.157-183 -김의원 (1983). 한국국토개발사연구 (A History: National Physical and Spatial Development in Korea). 대학도서 -김정렴 (1991). 한국경제정책 30년사: 김정렴 회고록. 서울: 중앙일보사. -김정탁 등 (2003). 문화를 통한 국가브랜드 가치 제고전략 최종보고서. 서울: 국가브랜드 경영연구소

-김흥기 (1999). 영욕의 한국경제: 경제기획원 33년. 서울: 매일경제신문사 -노화준 (2001). 한국정부의 전략적 발전관리의 특성: 전략적 수로서의 중화학공업정책의 추 진과정을 중심으로. 한국 행정학보, 35(2):41-61

-대외홍보위원회 (1996). 국가이미지 개선홍보 추진계획

-대통령자문 정책기획위원회 (2005). 국가경쟁력 제고를 위한 통합과 협의체 민주주의 연구 -대한무역투자진흥공사 KOTRA (2002). 2002 년 상반기 우리나라 수출주력품목의 해외시장 동향 분석- 10 대 주요 수출시장을 중심으로. KOTRA 기획조사 02-20

-대한무역투자진흥공사 KOTRA (1992). KOTRA30 년사 한국의 수출진흥 30 년 -대한무역투자진흥공사 KOTRA, 대한민국 수출성장 사 및 비전. Unpublished document -박기순 (1996). 한국기업의 해외 PR과 국가이미지 -박정희 (1963). 國家와 革命과 나. 서울: 지구촌 (1997년 재발행) -사공일 (2003). 개발연대의 경제정책과 개발계획(2)-유도계획적 5개년개발계획In 한국경제개발연구원 KDI (2003). KDI 정책연구사례-지난 30년의 회고-산업연구원 (2004). 주력산업의 현황과 향후 정책방향 연구 (I). 산업경제과-704 -산업자원부 (2005). 2005 경쟁력 강화를 위한 부품소재 산업백서 -산업자원부·산업연구원 (2003). 차세대 성장동력 (III) 미래유망산업 -서상목 (1986). 한국의 경제발전과 생산성향상운동. 한국 생산성본부 -서울대 한국경제연구원 (1973). 중화학공업화와 경제성장. 서울: 서울대학교 한국경제연구원. -송성수 (2005). 과학기술 종합계획에 관한 내용분석: 5 개년 계획을 중심으로. 과학기술정책 연구원, 정책연구 2005-16 
-중화학공업추진위원회기획단 (1997). 한국공업화발전에 대한 조사연구: 정책결정과정의 이면사. -연세대학교 언론 연구소 (1997). 주한외국인의 한국에 대한 이미지연구 -오미영, 박종민, 장지호 (2003). 상품평가 및 구매의도에 대한 원산지효과 연구:한국의 국가이미지를 중심으로. 정책분석평가학회보, 13(2): 23-49

-오원철 (1995). 한국형 경제건설:엔지니오링 어프로치, 제 1-5권. 서울:기아경제연구소 -오창우 (1989). 한국의 국가이미지에 관한 연구-미국.일본인들의 의식을 중심으로. 연세대학교 신문방송학 석사논문 -외교부 (1990). 한국외교 40년: 1948-1988

-유경준 편 (2004) 한국경제 구조변화와 고용창출. 한국개발연구원 $\mathrm{KDI}$ -유병용 외 (1997). 한국 현대 정치사의 재조명.한국정치외교사학회, 정치외교사논총, 15(3) -이정훈 (2000). 새로운 동반자 관계를 위한 박정희 시대의 한일관계. 한국정치사 기술학술회의 -한국경제개발연구원 KDI (2003). KDI 정책연구사례-지난 30년의 회고-한국경제개발연구원 KDI (1982). 「산업정책의 기본과제와 지원정책의 개편방안」. 서울: 한국경제연구원.

-한국무역협회 (2006). 2006년도 수출산업실태조사. GOVP1200703674

-한국무역협회 (1973). 제 3 차 경제개발 5 개년 계획 기간중의 수출목표 달성방안 -한국무역협회 (1996). 이미지가 선택좌우 -한국일보 (2007). 무역규모 7000 억달러 세계 11 위...1 조달러 클럽'도 넘본다.11 월 29 일자 -한국토지공사 (2002). 살고 싶은 터전 만들기 30 년(II).

-한충민 (1995). 한국의 대외이미지 현황 및 경제적 파급효과. 경제연구, 15(1):251-74

-해외홍보원 (Korea Overseas Information Service) (2003). Handbook of Korea, $11^{\text {th }} \mathrm{ed}$. Seoul: Hollym.

-홍춘자 (2006). 영국 유력 일간지에 나타난 한국 이미지 형성요소 분석 연구- The Times 와 The Guardian 의 1994 1995, 1999 2000, 2004 2005 년 기사를 중심으로. 연세대학교 언론홍보대학원 광고홍보 석사논문

-Amsden, A. H. (1989). Asia's Next Giant: South Korea and Late Industrialization. Oxford: Oxford University Press.

-Economic Planning Board of Korea, Economic Year Book

-Harvie, C.H. and Lee, H.H. (2003). Export-Led Industrialisation and Growth: Korea's Economic Miracle, 1962-1989. Australian Economic History Review, 43(3):256-86 -Hong, S.M. (2002). Modernization and Economic Development in the Korean Economy. Journal of the Korean-Turkish Acadeic Society. Vol. 4. The $3{ }^{\text {rd }}$ International Symposium on Middle East \& Korea Seoul: Korea-Turkish Academic Society 
-Lall, S. (1994). The East Asian miracle study: does the bell toll for industrial strategy? World Development, 22(4):645-54

-Lee, K.R.,Shim,S.W., Jeong, B.S., and Hwang, J.T. (2003).Knowledge Intensive Service Activities (KISAs) in Korea's Innovation System. Korea Science \& Technology Policy Institute, Seoul.

-MOFE·KDI School of Public Policy and Management (2006). A Way Forward for the Turkish Economy: Lessons from Korean Experiences. Knowledge Sharing Project (Sept)

-MOFE·KDI School of Public Policy and Management (2006). Reforming Key

Economic Institutions in Indonesia: Lessons from Korea's Development Experiences. Knowledge Sharing Project (Sept)

-MOFE- and KDI School (2005). Industrial Development and Export Promotion Policy for Uzebekistan Knowledge Sharing Project (Dec)

-MOFE-and KDI School (2005). Major Policy Agenda and Policy Responses toward a Globalized Market Economy for Vietnam. Knowledge Sharing Project (Dec) -OECD, Economic Survey (1996)

-The Korea Economic Weekly, August 21, 1995

-UN, Industrial Statistics Yearbook

-World Bank (1993), The East Asian Miracle: Economic Growth and Public Policy -http://www.economist.com/countries/SouthKorea/profile.cfm?folder=ProfileEconomic\%20Structure -http://www.imf.org/external/pubs/ft/weo/2006/01/data/dbcselm.cfm?G=2001 -http:// www.nvtc.gov

\section{BRANDING OF IRELAND}

-Key Informants

Coleman, J. IDA Ireland

Obrien, G. Enterprise Ireland

Faulkner, N. Enterprise Policy \& Communications Division, Forfás

-Ireland National Strategy

:Programme for National Recovery (PNR). Government Stationery Office (1987)

:Programme for Economic and Social Progress (PESP).Government Stationery Office (1991)

:Programme for Competitiveness and Work (PCW). Government Stationery Office (1994)

:Partnership 2000. Government Stationery Office (1996)

-Barry, F. (2006). FDI and Irish Economic Development over Four Stages of European Integration University College Dublin

-Burnham, J. B. (2003). Why Ireland Boomed. The Independent Review, VII (4):537-56

-Culliton, J. (1992). A Time for Change. Dublin: the Industrial Policy Review Group 
-Deloitte Report (2004). Study on the Future of the Financial Service Sector in Ireland -Department of Enterprise, Trade and Employment (2000). Technology Foresight Fund -Department of the Taoiseach (2006). Building on Success International Financial Services Industry in Ireland.

-Department of the Taoiseach (1999). Strategy for the Development of the International Financial Services Industry in Ireland

-Department of the Taoiseach (2000). Strategy for the Development of the International Financial Services Industry in Ireland. Progress Report

-Department of the Taoiseach (2000). e-Business in International Financial Services:

Developing Ireland's Potential Proposals for Action

-Dorgan, S. (2003). An Overview and history of the International Financial Service

Sector in Ireland by Sean Dorgan CEO. IDA Seoul 2003. Accessed IDA website 27-022006

-Dublin Docklands Development Authority. Master Plan 1997

-Dublin Docklands Development Authority. The Custom House Docks Planning Scheme, 1994;1987

-Economist Intelligence Unit (2004). Quality-of-life index, THE WORLD IN 2005 -FEFSI (2003). Net assets of European Investment Funds Industry -Forfás Activities. Each Year

-Forfás and National Competitiveness Council (2006). Annual Competitiveness Report 2006 Vol 1: Benchmarking Ireland's Performance

-Forfás (2005). Report of an International Evaluation Panel - Science Foundation Ireland The First Years 2001-2005

-Forfás (2005). Research and Development in Ireland in 2005. Dublin: Forfás

-Forfás (2004). Enterprise Strategy Group Report. Survey of Research and Development in the Higher Education Sector

-Forfás (2003). 2002 Review and 2003 Outlook Statement.

-Forfás Surveys, 2003

-Forfás (2000). Enterprise 2010 - new strategy for the promotion of enterprise in Ireland in the 21 st century

-Forfás (1996). Shaping our future - a strategy for enterprise in Ireland in the 21st century -Forfás (1995). Employment Survey

-Florida, R. and Tinagli, I. (2004). Europe in the Creative Age. London: Demos

-FRY, W. (2001). Ireland: Locating a business and living in Ireland

-Government of Ireland (2000). Planning and Development Act 2000. Dublin:

Government Stationery Office

-Government of Ireland (1999). National Development Plan 2000-2006. Dublin:

Government Stationery Office

-Government of Ireland (1993). National Development Plan 1994-1999. Dublin:

Government Stationery Office 
-ICSTI/Forfás (1999). Technology Foresight Ireland (TFI). Dublin: Forfás

-ICSTI/Forfás (1998). ICSTI Statement - Science, Technology and Innovation Culture

-IDA Ireland. Annual Reports, 1986-2005. Dublin: IDA Ireland

-IDA Ireland. Brand Guidelines.

-IDA Connect: Knowledge Theme Page

< http://idaconnect/IDAInformation/KnowledgeTheme/>

-IMD World Competitiveness Yearbook 2007

-IMD World Competitiveness Yearbook 2003

-Irish Central Statistical Office, 2003

-Irish Statute Book. Dublin Docklands Development Authority Act 1997. <http://www.irishstatutebook.ie/1997/en/act/pub/0007/index.html>

-Irish Statute Book. The Urban Renewal Act 1987.

<http://www.irishstatutebook.ie/1987/en/act/pub/0016/index.html>

-National Economic and Social Council (NESC) (1999).Opportunities, Challenges and

Capacities for Choice: Overview, Conclusions and Recommendations

-National Economic and Social Council (NESC) (1996). Strategy into $21^{\text {st }}$ Century

-National Economic and Social Council (NESC) (1993). A Strategy for

Competitiveness, Growth and Employment.

-National Economic and Social Council (NESC) (1990). A Strategy for the Nineties:

Economic Stability and Structure Change.

-National Economic and Social Council (NESC) (1986). A Strategy for Development 1986-90

-OECD Economic Outlook, 1999-2005

-OECD Historical Statistics, 1960-1990

-Porter, M.E. (2003). The global competitiveness report 2002-2003. Geneva: World

Economic Forum

-Review of Industrial Performance and Policy 2003. Dublin: Government Stationery

Office

-UNCTAD (2006). TNCs and the internalization of R\&D. World Investment Report 2005

-Williams, B. and Shiels, P. (2003). The Financial Service Sector in Dublin, in Cahiers de l'laurifn135 Economic Performance of the European Regions.

<http://www.iaurif.org/en/doc/studies/cahiers/cahier_135/pdf/161-168.pdf>

-Williams, B. and Redmond, D. (2006) Ideopolis: Knowledge City Region Dublin Case

Study, London: The Work Foundation

-http://www.taoiseach.gov.ie/index.asp?locID=502\&docID=-1

-http://www.nesc.ie/publications.asp

-http://www.irlgov.ie/Taoiseach/press/current/28-02-2000.htm

-http://www.ifsconline.ie/

-http://www.entemp.ie/publication.PDF 